THE ECOLOGY, LIFE HISTORY, AND PHYLOGENY OF THE MARINE THECATE HETEROTROPHIC DINOFLAGELLATES PROTOPERIDINIUM AND DIPLOPSALIDACEAE (DINOPHYCEAE)

\author{
by \\ Kristin Elizabeth Gribble \\ B.A. Lawrence University, 1994 \\ Submitted in partial fulfillment of the requirements for the degree of \\ Doctor of Philosophy \\ at the \\ MASSACHUSETTS INSTITUTE OF TECHNOLOGY \\ and the \\ WOODS HOLE OCEANOGRAPHIC INSTITUTION
}

September 2006

(C) Kristin E. Gribble 2006

All rights reserved

The author hereby grants to MIT and WHOI permission to reproduce and distribute publicly paper and electronic copies of this thesis document in whole or in part in any medium now known or hereafter present.

Signature of Author

Joint Program in Biological Oceanography

Massachusetts Institute of Technology/Woods Hole Oceanographic Institution

Certified by

n

Thesis Supervisor

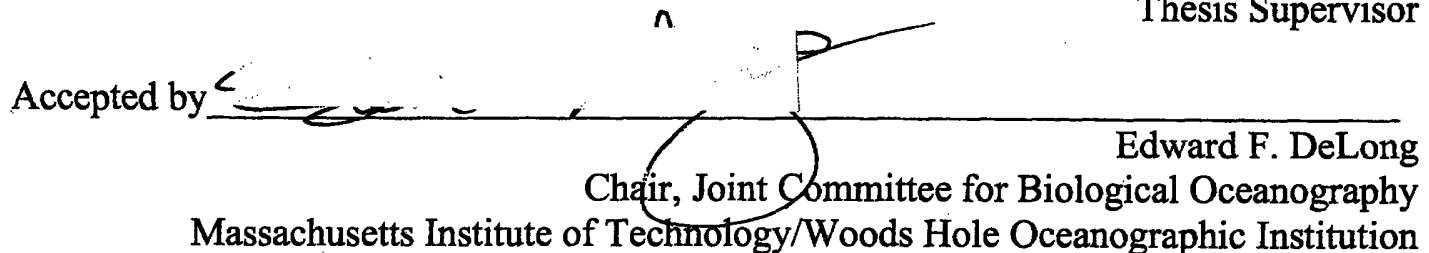

Massachusetts Institute of Technology/Woods Hole Oceanographic Institution 



\title{
THE ECOLOGY, LIFE HISTORY, AND PHYLOGENY OF THE MARINE THECATE HETEROTROPHIC DINOFLAGELLATES PROTOPERIDINIUM AND DIPLOPSALIDACEAE (DINOPHYCEAE)
}

\author{
by \\ Kristin Elizabeth Gribble \\ Submitted to the Massachusetts Institute of Technology/Woods Hole Oceanographic \\ Institution Joint Program in Biological Oceanography on July 26, 2006 in partial \\ fulfillment of the requirements for the degree of Doctor of Philosophy
}

\begin{abstract}
Marine thecate heterotrophic dinoflagellates likely play an important role in the consumption of primary productivity and in the trophic structure of the plankton, yet we know little about these species. This thesis expanded our understanding of the autecology and evolutionary history of the Protoperidinium and diplopsalids.

The distributions of Protoperidinium species off the southwestern coast of Ireland were influenced by physical oceanographic conditions coupled with the availability of preferred prey. The distributions of individual Protoperidinium species varied widely from the distribution of total Protoperidinium, indicating differences in ecologies among species. Certain species of Protoperidinium co-occurred with known preferred phytoplankton prey species. Concentrations of other Protoperidinium species were not related to those of any particular phytoplankton species, indicating that these Protoperidinium may rely on phytoplankton or other food sources beyond those already known, may not be species specific selective feeders, or may have become uncoupled from their preferred prey.

The description of the sexual and asexual life history of Protoperidinium steidingerae provided the first account of the life history of any Protoperidinium species. Asexual division occurred by eleutheroschisis within a temporary, immotile cyst, yielding two daughter cells. Daughter cells were initially round and half to two-thirds the size of parent cells, then rapidly increased in size, forming horns before separating. Sexual reproduction was constitutive in clonal cultures, indicating that the species may be homothallic. Fusing gametes were isogamous, and resulted in a planozygote with two longitudinal flagella. Hypnozygotes had a mandatory dormancy period of ca. 70 days. Germination resulted in planomeiocytes with two longitudinal flagella. Nuclear cyclosis may occur in the planomeiocyte stage. A high level of morphological diversity among life history stages of $P$. steidingerae has led to mis-classification and taxonomic inaccuracy of Protoperidinium species identified from field samples.

The large subunit ribosomal DNA (LSU rDNA) molecular phylogeny of the heterotrophic dinoflagellates revealed that the genus Protoperidinium appeared to be recently diverged within the dinoflagellates. In maximum parsimony and neighbor
\end{abstract}


joining analysis, Protoperidinium formed a monophyletic group, evolving from diplopsalid dinoflagellates. In maximum likelihood and Bayesian analyses, however, Protoperidinium was polyphyletic, as the lenticular, diplopsalid heterotroph, Diplopsalis lenticula Bergh, was inserted within the Protoperidinium clade basal to Protoperidinium excentricum (Paulsen) Balech, and Preperidinium meunieri (Pavillard) Elbrächter fell within a separate clade as a sister to the Oceanica section and Protoperidinium steidingerae Balech. In all analyses, the Protoperidinium were divided into two major clades, with members in the Oceanica group and subgenus Testeria in one clade, and the Excentrica, Conica, Pellucida, Pyriforme, and Divergens sections in another clade. The LSU rDNA molecular phylogeny supported the historical morphologically determined sections, but not a simple morphology-based model of evolution based on thecal plate shape.

LSU rDNA gene sequences are frequently used to infer the phylogeny of organisms. The many copies of the LSU rDNA found in the genome are thought to be kept homogenous by concerted evolution. In Protoperidinium species, however, there was high intragenomic diversity in the D1-D6 region of the LSU rDNA. For each species, the clone library was usually comprised of one highly represented copy and many unique sequences. Sequence differences were primarily characterized by single base pair substitutions, single base pair insertion/deletions (indels), and/or large indels. Phylogenetic analysis of all clones gave strong support for monophyly of the polymorphic copies of each species, and recovered the same species tree as an analysis using just one sequence per species. Analysis of LSU rDNA gene expression in three species by RT-PCR indicated that copies with fewer substitutions and fewer and smaller indels are expressed, and that $50 \%$ or more of the copies are pseudogenes. High intraspecific and intraindividual LSU rDNA sequence variability could lead to inaccurate species phylogenies and over-estimation of species diversity in environmental sequencing studies.

This thesis has explored the ecology, life history, molecular phylogeny, and intraspecific DNA sequence variability of marine thecate heterotrohic dinoflagellates using a wide range of methodologies, including field sampling, culturing, microscopy, morphological analyses, histological staining, and molecular biology. The work here has broadened our understanding of the Protoperidinium and diplopsalids, providing new insights into the ecological and evolutionary relationships of these heterotrophs with other plankton species.

Thesis Supervisior: Dr. Donald M. Anderson

Senior Scientist, Biology Department, Woods Hole Oceanographic Institution 


\section{TABLE OF CONTENTS}

$\begin{array}{lr}\text { Abstract } & 3\end{array}$

$\begin{array}{ll}\text { Acknowledgements } & 7\end{array}$

Chapter 1. Introduction 9

Chapter 2. Distributions and trophic relationships of Protoperidinium spp. (Dinophyceae) and phytoplankton off the southwestern coast of Ireland in July 2003

Introduction $\quad 27$

Materials and Methods $\quad 29$

Results $\quad 32$

Discussion $\quad 85$

References $\quad 94$

Chapter 3. Sexual and asexual reproduction in Protoperidinium

steidingerae Balech (Dinophyceae) $\quad 99$

$\begin{array}{ll}\text { Abstract } & 100\end{array}$

Introduction $\quad 101$

Materials and Methods $\quad 102$

$\begin{array}{ll}\text { Results } & 109\end{array}$

Discussion $\quad 139$

$\begin{array}{ll}\text { References } & 147\end{array}$

Chapter 4. Molecular phylogeny of the heterotrophic dinoflagellates, Protoperidinium, Diplopsalis, and Preperidinium (Dinophyceae), inferred from LSU rDNA

Introduction $\quad 153$

$\begin{array}{lr}\text { Materials and Methods } & 159\end{array}$

$\begin{array}{ll}\text { Results } & 167\end{array}$

$\begin{array}{ll}\text { Discussion } & 185\end{array}$

$\begin{array}{ll}\text { References } & 192\end{array}$ 
Chapter 5. High intragenomic variability in large subunit ribosomal DNA genes in the heterotrophic dinoflagellates Protoperidinium, Diplopsalis, and Preperidinium (Dinophyceae)

Introduction

Materials and Methods

Results

Discussion

References

Chapter 6. Conclusions and suggestions for future study

Appendix 1. Protoperidinium species: Group predators of large zooplankton or detritivores?

Appendix 2. Observations of the asexual and sexual life history of Protoperidinium depressum (Dinophyceae) 


\section{ACKNOWLEDGEMENTS}

Although this thesis bears only my name, many have helped me along the way to achieving this goal. My thesis committee, including my advisor Don Anderson, Penny Chisholm, D. Wayne Coats, Sonya Dyhrman and Mark Hahn, has been supportive, enthusiastic, and helpful. Thanks to Don for giving me the freedom to pursue my interests. To Wayne, thank you for being both good mentor and a friend. Special thanks to Sonya for listening and for good advice on both scientific and personal topics. Mark and Penny were both very encouraging and provided important feedback on the thesis.

Too many great people have passed through the Anderson lab during my stay for me to name them all. Thanks in particular to Bruce for bringing me into the lab and teaching me about field work, to Dave for babysitting my cultures and keeping the lab running, and to Judy who provided a friendly ear and help with all things logistical. I am grateful to Deana Erdner, Linda McCauley and Claudia Martins for sharing their expertise in molecular biology, lunches outside, and moral support. My many fellow Joint Program officemates over the years helped negotiate the logistics of graduate school, and provided scientific support and commiseration.

To my WHOI Biology classmates, Joy Lapseritis, Gareth Lawson, Sheri Simmons, Eric Montie, Tin Klanjscek, and Welkin Pope, thank you for the MIT support group, the general exam support group, the thesis proposal support group, and the thesis support group. I cannot imagine a better group of people with whom to have gone through this process.

My research was supported primarily by the Comer Foundation. This thesis could not have taken its current form without the financial freedom allowed me by Gary Comer's generous gift six years ago. Additional financial support was provided by the Carroll Wilson Award from the MIT Entrepreneurship Society, the Cove Point Foundation, and 
National Science Foundation grant OCE-0136861. The Biology Department Education Fund provided the money needed for scanning electron microscopy. Funding from the WHOI Academic Programs Office and the MIT Student Assistance Fund allowed me to attend conferences, for which I am grateful.

Thank you to my parents, Jack and Barb for giving me what it took to pursue this goal. You set a life-long example for me through your integrity and hard work and have always encouraged me to pursue my interests and to do my best. Thank you for continuing to believe in me.

To my husband Ken, I cannot give enough thanks. Your love and emotional support (along with your fantastic cooking!) have kept me going over the last six years. Thanks for taking samples, building plankton wheels, and picking up the ball when I dropped it. Thank you for making me laugh, helping me keep life in perspective, and not letting me quit when the going got rough. As per your suggestion, I kicked it in the ass! 
Chapter 1

Introduction 
The Dinophyceae is an extremely diverse group of planktonic organisms comprised of approximately 2000 described species, $90 \%$ of which are marine. Fully half of the freeliving species of dinoflagellates are heterotrophic, lacking chloroplasts and relying on particulate or dissolved organic matter for nutrition. Additionally, many of those dinoflagellate species with chloroplasts are now known to be mixotrophic, meeting their nutritional requirements through a combination of phototrophy and heterotrophy (Gaines and Elbrächter 1987; Graneli and Carlsson 1998; Stoecker 1999).

One of the largest groups of thecate, heterotrophic dinoflagellates is the genus Protoperidinium Bergh, comprised of more than 200 globally distributed species (Balech 1974). The Diplopsaloideae is a sub-family of lenticular thecate heterotrophic dinoflagellates. Despite their nearly universal and frequent occurrence in the plankton, we know little about these species. In addition to a few studies of taxonomy and limited examination of distribution in the field, authors have focused primarily on laboratory investigations of feeding rates, preferred foods, and growth rates of a handful of Protoperidinium species. The relative importance of Protoperidinium or diplopsalid thecate heterotropic dinoflagellates in structuring marine food webs or in recycling organic matter is not well studied. The details of the life histories of the thecate heterotrophic dinoflagellates, including sexuality, mating behavior, and cyst formation, are largely inferred from those of autotrophic dinoflagellates. At the time of the initiation of this thesis research, nothing was known of the molecular evolution of the Protoperidinium or the diplopsalids.

\section{Feeding and Trophic Status}

Most studies of Protoperidinium thus far have been laboratory studies focused on feeding behavior, feeding rates, preferred food species, and the influence of different prey types on growth rate. All Protoperidinium and diplopsalids are raptorial feeders. These species consume prey by the unique mechanism of "pallium feeding" in which the heterotroph exudes a pseudopod or "pallium" that surrounds its phytoplankton prey. Digestion occurs within the pallium, external to the heterotroph cell (Gaines and Taylor 1984; Jacobson and Anderson 1986). 
Some thecate heterotrophic dinoflagellates are highly specific grazers while others are generalists (Jacobson 1987; Buskey et al. 1994; Naustvoll 2000). Although some Protoperidinium spp. have higher consumption and growth rates on diatom prey relative to dinoflagellate prey (Jacobson 1987; Naustvoll 2000), a few, including Protoperidinium crassipes (Kofoid) Balech, Protoperidinium divergens (Ehrenberg) Balech, and Protoperidinium steinii (Jorgensen) Balech, exhibit positive growth rates only when feeding on dinoflagellate prey (Jeong and Latz 1994; Naustvoll 2000). Many species have been shown in laboratory studies to be highly specific feeders, apparently able to grow on a particular phytoplankton species, but unable to survive on prey similarly sized or closely related (even within the same genus) to their preferred food.

The Protoperidinium and diplopsalids represent exceptions to the paradigm of sizestructured food webs. Unlike other "microzooplankton," such as ciliates which consume small flagellates and bacteria, Protoperidinium and diplopsalid species consume prey as large or larger than themselves, with the average ratio of predator size to prey size near 1:1 (Jacobson and Anderson 1986; Hansen et al. 1994; Naustvoll 2000). As grazers of large diatoms and dinoflagellates, Protoperidinium and diplopsalids likely compete with larger zooplankton, like copepods, for food. In addition to commonly eating prey larger than themselves, some Protoperidinium species are also known to eat the eggs and nauplii of copepods, the adults of which may in turn prey on Protoperidinium (Jeong 1996). In cultures with limited food resources, several Protoperidinium species have been observed to be cannibalistic (Jeong 1995; Naustvoll 2000).

\section{Distribution and Ecology}

A few studies have looked specifically at the distribution of thecate heterotrophic dinoflagellates in a variety of habitat types, including a eutrophic, temperate, salt pond on the coast of Massachusetts (Jacobson 1987), the oligotrophic tropical Sargasso Sea (Lessard and Murrell 1996), a fjord in Norway (Kjaeret et al. 2000), and the arctic and sub-arctic (Levinsen et al. 2000). Several others have included Protoperidinium and 
other thecate heterotrophic dinoflagellates as part of larger plankton community studies. These works reveal a couple of important features of the ecology of Protoperidinium.

First, the occurrence of some Protoperidinium and diplopsalid species is highly seasonal, while other species are found year round. In temperate Perch Pond, Massachusetts, Jacobson (1987) found all species of Protoperidinium to be seasonal, while diplopsalids, such as Oblea rotunda (Lebour) Balech ex Sournia and Preperidinium meunerii (Pavillard) Elbrächter (syn. Zygabikodinium lenticulatum), were present throughout the year. Protoperidinium punctulatum (Paulsen) Balech, Protoperidinium bipes (Paulsen) Balech, Protoperidinium conicoides (Paulsen) Balech and Protoperidinium pellucidum Bergh occurred in the spring. Protoperidinium conicum (Gran) Balech occurred in both the spring and the fall, while Protoperidinium oblongum (Aurivillius) Parke and Dodge and Protoperidinium spinulosum Schiller were present only in the summer. Many species were detected over a wide range in temperature (Jacobson 1987). In the inner Oslofjord of Norway, $P$. pellucidum and $P$. conicoides were associated with the spring diatom bloom, Protoperidinium divergens (Ehrenberg) Balech with the mixed dinoflagellate-diatom bloom in late August, and $P$. granii (Ostenfeld) Balech and other species with a bloom of Pseudo-nitzschia pseudodelicatissima (Hasle) Hasle in October (Kjaeret et al. 2000).

Second, distribution and seasonality appear to be driven by the availability of prey. For example, in a two-season time series study at the JGOFS station in the Sargasso Sea near Bermuda, Lessard and Murrell (1996) found that in general, protistan biomass and abundance exhibited subsurface maxima that were often near the deep chlorophyll maximum (DCM). Rapid changes in the protistan community structure at this maximum were associated with changes in the dominant phototroph in the DCM. When picoplankton dominated the DCM, the protistan community was composed primarily of ciliates, which preferentially consume small phytoplankton. When a warm, saline eddy entered the study area, the composition of the DCM changed from picoplankton to diatoms and large $(>20 \mu \mathrm{m})$, thecate heterotrophic dinoflagellates, primarily Protoperidinium spp. and Diplopsalis spp. Bergh. At the same time, a second, deeper 
chlorophyll maximum was dominated by cyanobacteria. Large, thecate dinoflagellates were absent and small gymnodinoid dinoflagellates were present in this deeper chlorophyll layer.

Kjaeret et al. (2000) also found that several Protoperidinium species reached their maximum abundance during or immediately after peaks in autotrophic biomass. For example, in 1994 when the diatom Thallasiosira norddenskioeldii Cleve dominated the spring bloom, $P$. pellucidum and $P$. conicoides were abundant, while in 1995 when Skeletonema sp. Greville dominated the spring bloom, P. brevipes replaced the other two Protoperidinium spp. The annual cycle of $P$. divergens appears dictated by the availability of suitable autotrophic dinoflagellates. These results correspond well to laboratory studies of preferred food types for these Protoperidinium species (Kjaeret et al. 2000). While the distribution of large, thecate heterotrophic dinoflagellates appears to be driven primarily by food availability, the data do not exist to exclude grazing or physical parameters like temperature as controls of Protoperidinium spp. distributions.

\section{Life history}

Taxonomic investigation of cysts collected in the field and subsequently germinated in the lab has allowed elucidation of the cyst-theca relationships of many species of Protoperidinium and diplopsalids (Wall and Dale 1968; Lewis et al. 1984). At the outset of this thesis, however, nothing was known of the life history stages or reproductive behaviors that occur during the cycle from the cyst to the vegetative cell and back again in any Protoperidinium or diplopsalid species. It was not understood how environmental

conditions trigger sexuality and affect cyst formation or germination, and thereby influence population dynamics.

Many cyst-forming dinoflagellates have been found to have similar life history strategies (Pfiester and Anderson 1987). Reproduction of haploid swimming cells is generally by asexual division. In times of environmental or nutritional stress, vegetative cells may form gametes. Subsequent sexual reproduction by fusion of gametes leads to a swimming, diploid planozygote that forms a non-motile hypnozygote, or cyst. After 
some mandatory dormancy period, the cyst will germinate when environmental conditions are amenable to growth in the water column. The germinated swimming cell, or planomeiocyte, divides to again form haploid vegetative cells. There are many variations on this theme among species, however. Depending upon the species, mating may be homothallic (within a clone), heterothallic (between clones of different mating types), or in some species, both. Gametes may be homogamous, where gametes are of the same morphology as each other and as vegetative cells, isogamous, where gametes look different than vegetative cells, but the same as one another, or anisogamous, where fusing gametes have different morphologies than the vegetative cells and than one another. Different species have varying lengths of cyst maturation or mandatory dormancy periods and respond to different triggers for germination, including the presence or absence of a biological clock. (Anderson and Keafer 1987; Pfiester and Anderson 1987).

Recognizing the various morphologies that a species may take at different life history stages is important in the design and interpretation of field studies. Incomplete understanding of the life cycle of a dinoflagellate species may lead to taxonomic confusion. For example, the life history stages of Pyrocystis lunula (Schütt) Schütt and Dissodinium pseudolunula Swift ex Elbrächter and Drebes were, for almost a century, mistakenly integrated into an incomplete life cycle of a single species. In another case, some stages of the life cycle of Cystodinedria inermis, known only from field specimens, appeared to be identical to Actinophrys sol and other distinct protist species (as discussed in Coats 2002). Being unaware of the morphologies of, or triggers for, different life cycle stages can cause misinterpretation of data when trying to understand the ecology of an organism or the seasonal dynamics of a system. Knowledge of the life history of an organism is also important in understanding how a population might respond to a given set of environmental conditions, and help us evaluate whether the seasonality of a species might be controlled either by bottom-up food supply, top-down grazing pressures, temperature-induced cyst formation, a molecular clock, or some combination of these and other factors. 
The life histories of seasonal species may differ from those of species that persist yearround or that occur in different seasons from year to year. Additionally, the life history strategy of the same species may differ between regions. For example, Alexandrium fundyense relies on different triggers for germination of cysts in different environments. In shallow embayments along the Northeast coast of the U.S., cysts germinate in response to longer days and warmer temperatures. In the deep waters of the Gulf of Maine in the North Atlantic, however, where $A$. fundyense is removed from the environmental cues of surface waters, the species relies on an internal clock to time germination in late spring, when conditions are favorable for growth (Anderson and Keafer 1987).

\section{Phylogeny}

Although the taxonomy of the morphologically diverse genus Protoperidinium and the diplopsalids has been thoroughly investigated (Taylor 1976; Abé 1981; Dodge 1982; Dodge 1983), at the inception of this thesis research nothing was known of the genetic diversity or evolutionary history of the these species. Until relatively recently, our view of the evolutionary relationships among the dinoflagellates was based entirely on morphology. A variety of competing morphological models were used to order the many dinoflagellate families. These models included the "plate increase model," in which taxa with fewer thecal plates are ancestral and unarmoured species are derived; the "plate reduction model," in which unarmoured species are ancestral, intermediate groups have many thin plates, and derived species are more heavily armoured with few plates; and the "plate fragmentation model," in which the two valves of ancestral species differentiated into many plates and later gave way to unarmored forms. Pigment type, chloroplast structure, and chromosome structure were also used to infer relationships between taxa (Saunders et al. 1997). In most of these models, the Peridiniales, including the Protoperidinium, are shown arising mid-way along the evolution of the dinoflagellates.

The heterotrophic nature of Protoperidinium species has caused them to be placed at the bottom of some dinoflagellate evolutionary trees (Tomas and Cox, 1973; Loeblich, 1976, Dodge, 1979, Spero, 1979, as reviewed in Steidinger and Cox, 1980). This paradigm is based on the endosymbiotic theory proposed by Margulis $(1968 ; 1970)$ which 
hypothesizes that photosynthetic eukaryotes evolved through a series of symbiotic relationships between heterotrophic protists and autotrophic prokaryotes. The endosymbiotic theory is valid in general, but recent genetic evidence has shown that some heterotrophic dinoflagellate species may have gained and subsequently lost chloroplasts more than once during their history (Saldarriaga et al. 2001).

Over the last decade, our understanding of dinoflagellate evolution has been radically altered by molecular systematics (Saunders et al. 1997; Daugbjerg et al. 2000; Saldarriaga et al. 2001). For many years, however, studies of dinoflagellate phylogenetics based on small subunit ribosomal DNA (SSU rDNA) (Saunders et al. 1997; Saldarriaga et al. 2001) or large subunit ribosomal DNA (LSU rDNA) sequence data (Daugbjerg et al. 2000) have not included Protoperidinium species. That no one had examined the phylogenetics of the genus was likely due to two factors: First, these heterotrophs must be grown with their prey in the laboratory, making extraction of species-specific DNA from cultures non-trivial. Second, there was an apparent inability to easily produce clean PCR products from single or low numbers of trophic cells or from resting cysts of Protoperidinium, as had been done for other species (Saunders et al. 1997; Bolch 2001).

Several researchers had tried and failed to obtain sequences of either LSU rDNA (Bolch 2001) or SSU rDNA (Saunders et al. 1997; Bolch 2001) from a variety of Protoperidinium species. Most of these studies were not targeted investigations of Protoperidinium, but included Protoperidinium species among other phytoplankton used in demonstration of new molecular methods. Authors had generally cited unknown "PCR inhibitors" as the reason for their difficulty.

Recently, other workers have begun to make inroads into the molecular phylogeny of the Protoperidinium, using SSU rDNA (Saldarriaga et al. 2004; Yamaguchi and Horiguchi 2005). This sequence information is useful, but the SSU rDNA may not be sufficiently variable for phylogenetic resolution of some species and groups. Until now, however, there were no published LSU rDNA sequences for any Protoperidinium species, and no 
gene sequences of any kind for any diplopsalid species. The LSU rDNA has more variability that the SSU rDNA, and thus may offer new insights.

\section{Toxicity in Protoperidinium}

Most of the known toxic, marine phytoplankton-those causing illness or death in marine wildlife and humans-are dinoflagellates. Until recently, all of these toxic dinoflagellates were believed to be autotrophic. We are increasingly discovering mixotrophy in toxic species, however, including Dinophysis acuminata Claparède and Lachmann and Dinophysis acuta Ehrenberg, which produce diarrhetic shellfish poisoning (DSP) toxins (Jacobson and Andersen 1994; Graneli et al. 1997), Alexandrium ostenfeldii (Paulsen) Balech and Tangen, the source of spirolide shellfish toxins (Jacobson and Andersen 1994; Cembella et al. 2001), and the haptophyte Prymesium patelliferum Green, Hiberd, and Pienaar, producer of prymesium toxins (Legrand et al. 2001). Nearly a decade ago, the first toxic heterotrophic dinoflagellate, Pfiesteria piscida Steidinger and Burkholder, was identified. The ichthyotoxicity of this species appeared to be triggered by exposure to fish prey (Burkholder and Glasgow Jr. 1997).

In 1995, a new type of shellfish poisoning, now named azaspiracid shellfish poisoning (AZP), was discovered when consumers in the Netherlands became ill after eating mussels cultured in Killary Harbor, Ireland. Since then, azaspiracid (AZA) toxicity has also occurred in shellfish in Norway and the U.K. (James et al. 2002a). AZAs are potent, lipid-soluble neurotoxins, the pharmacology of which is generally unknown. Consumption of contaminated shellfish by humans is manifested by symptoms of severe gastroenteritis, and for that reason the syndrome may be confused with diarrhetic shellfish poisoning (DSP). The full human etiology of AZA is unknown, but tests on laboratory mice have shown that chronic doses of AZA too low to cause acute illness result in damage to the liver, small intestine, and lymphoid tissues including the thymus and spleen. Low, chronic doses of AZA were observed to be carcinogenic in laboratory mice, causing lung tumors (Ito et al. 2002). Cytological assays have indicated that AZAs are neither sodium channel blockers like the paralytic shellfish poisoning (PSP) toxins, 
nor phosphatase inhibitors, like the DSP toxins. AZAs cause apoptosis and inhibition of protein synthesis when applied in cell culture assays (Flanagan 2002).

The AZAs, originally described after isolation from shellfish, were not linked to a causative organism until 1999, when a plankton net tow with abundant Protoperidinium crassipes (Kofoid) Balech tested positive for AZA. That report was substantiated by similar results from a plankton net tow in 2001 (Irish Marine Institute Unpubl. data). Since then, workers used LC-MS to analyze pooled single-cell isolations of $P$. crassipes from field samples to identify the species as the source of AZAs (Yasumoto et al. 2002; James et al. 2003). Preliminary results indicated that Protoperidinium depressum (Bailey) Balech, though morphologically similar to $P$. crassipes, may not be toxic (James et al. 2002b; Yasumoto et al. 2002). Most other Protoperidinium species have not been tested individually for AZA.

The link between $P$. crassipes and AZA, originally a motivation for undertaking this thesis research, now appears tenuous, as production of AZA by $P$. crassipes has not been verified since the initial observation, and recent occurrences of AZP off the coast of Ireland have not been well correlated with the presence of the species (Moran et al. 2005). The previous detection of AZA in $P$. crassipes cells but not in other Protoperidinium species (James et al. 2003) may indicate that if $P$. crassipes does not produce AZA endogenously, it might accumulate the toxin from its phytoplankton prey. Preliminary evidence showed that $P$. crassipes was able to concentrate DSP toxins from Dinophysis spp. (Chris Miles International Conference on Molluscan Shellfish Safety, Galway, Ireland 2004) indicating a possible role of $P$. crassipes, and perhaps other Protoperidinium spp., as vectors of phycotoxins. In either case, understanding the ecology and trophic role of Protoperidinium spp. may be important to comprehending the dynamics of toxic phytoplankton blooms and shellfish toxicity. 


\section{Objectives and Overview of Thesis}

The overall objective of this thesis was to bring about a better understanding of the distribution, life history, and phylogeny of species of thecate heterotrophic dinoflagellates, including the Protoperidinium and diplopsalids. These heterotrophs are an important, but poorly characterized, component of marine ecosystems. To illuminate the role of thecate heterotrophic dinoflagellates in the plankton, I studied a range of diverse but related aspects of the Protoperidinium and diplopsalids. Chapter 2 explored the distributions of Protoperidinium species off the southwestern coast of Ireland, a region where toxic harmful algal blooms frequently impact the productive and economically important shellfish aquaculture industry. Co-occurrence of individual Protoperidinium species with specific phytoplankton species in the area was used to postulate possible specific trophic relationships. Chapter 3 provided the first description of the life history of any Protoperidinium species, including both sexual and asexual reproduction. In chapter 4, I explored the molecular phylogeny of Protoperidinium and diplopsalid species, inferred from LSU rDNA sequences, and used this phylogeny to discuss the relevance of historical, morphologically based categories that have been established for the Protoperidinium. The work described in chapter 5 arose as an offshoot of the phylogenetic studies of chapter 4, and strove to describe the high degree of intraspecific LSU rDNA sequence diversity uncovered in the thecate heterotrophic dinoflagellates.

The separate objectives and topics addressed in this work explored facets of thecate heterotrophic dinoflagellates that, in nature, are inextricably linked. Molecular phylogeny provides insight as to how life history and adaptive strategies have evolved. The life histories of Protoperidinium and diplopsalid species affect their distributions and abundances, which in turn influence plankton trophic dynamics.

\section{REFERENCES}

ABé, T. H. 1981. Studies on the Family Peridiniidae: An Unfinished Monograph of the Armoured Dinoflagellata. Academia Scientific Book, Inc. 
Anderson, D. M., and B. A. KeAfER. 1987. An endogenous annual clock in the toxic marine dinoflagellate Gonyaulax tamarensis. Nature 325: 616-617.

BALECH, E. 1974. El genero Protoperidinium Bergh, 1881 (Peridinium Ehrenberg, 1831, Partim). Revista del Museo Argentino de Ciencias Naturales "Bernardino Rivadavia" e Instituto Nacional de Investigacion de las Ciencias Naturales 4: 179.

BoLCH, C. J. S. 2001. PCR protocols for genetic identification of dinoflagellates directly from single cysts and plankton cells. Phycologia 40: 162-167.

BURKHOLDER, J. A. M., and H. B. Glasgow JR. 1997. Trophic controls on stage transformations of a toxic ambush predator dinoflagellate. Journal of Eukaryotic Microbiology 44: 200-205.

Buskey, E. J., C. J. CoulTER, and S. L. BROWN. 1994. Feeding, growth and bioluminescence of the heterotrophic dinoflagellate Protoperidinium huberi. Marine Biology 121: 373-380.

Cembella, A. D., A. G. Bauder, N. I. Lewis, and M. A. Quilliam. 2001. Association of the gonyaulacoid dinoflagellate Alexandrium ostenfeldii with spirolide toxins in size-fractionated plankton. Journal of Plankton Research 23: 1413-1419.

CoATs, D. W. 2002. Dinoflagellate life-cycle complexities. Journal of Phycology 38: 417-419.

DaugbJerg, N., G. Hansen, J. Larsen, and $\emptyset$. Moestrup. 2000. Phylogeny of some of the major genera of dinoflagellates based on ultrastructure and partial LSU rDNA sequence data, including the erection of three new genera of unarmoured dinoflagellates. Phycologia 39: 302-317.

DoDGE, J. D. 1982. Marine Dinoflagellates of the British Isles. Her Majesty's Stationery Office.

--- 1983. Ornamentation of thecal plates in Protoperidinium (Dinophyceae) as seen by scanning electron microscopy. Journal of Plankton Research 5: 119-127.

Flanagan, A. F. 2002. Detection and biochemical studies on the novel algal toxin, azaspiracid, p. 117, Department of Biochemistry. National University of Ireland, Galway. 
GAINES, G., and M. ELBRÄCHTER. 1987. Heterotrophic nutrition, p. 225-268. In F. J. R. Taylor [ed.], The Biology of Dinoflagellates. Botanical Monographs. Blackwell Scientific Publications.

GAINES, G., and F. J. R. TAYLOR. 1984. Extracellular digestion in marine dinoflagellates. Journal of Plankton Research 6: 1057-1062.

Graneli, E., D. M. Anderson, P. Carlsson, and S. Y. Maestrini. 1997. Light and dark carbon uptake by Dinophysis species in comparison to other photosynthetic and heterotrophic dinoflagellates. Aquatic Microbial Ecology 13: 177-186.

GranEl, E., and P. CARLSSON. 1998. The ecological significance of phagotrophy in photosynthetic dinoflagellates, p. 539-557. In D. M. Anderson, A. D. Cembella and G. M. Hallegraeff [eds.], Physiological Ecology of Harmful Algal Blooms. Springer-Verlag.

HANSEN, B., P. K. BJoRnSEN, and P. J. HANSEN. 1994. Prey size selection in planktonic zooplankton. Limnology and Oceanography 39: 395-403.

Ito, E., M. SATAKe, K. Ofuji, M. Higashi, K. Harigaya, T. McMahon, and T. YASUMOTO. 2002. Chronic effects in mice caused by oral administration of sublethal doses of azaspiracid, a new marine toxin isolated from mussels. Toxicon 40: 193-203.

JACOBSON, D. M. 1987. The ecology and feeding behaviour of thecate heterotrophic dinoflagellates, p. 209, Joint Program in Oceanography and Engineering. Woods Hole Oceanographic Institution-Massachusetts Institute of Technology.

JACOBSON, D. M., and R. A. ANDERSEN. 1994. The discovery of mixotrophy in photosynthetic species of Dinophysis (Dinophyceae): Light and electron microscopical observations of food vacuoles in Dinophysis acuminata, $D$. norvegica and two heterotrophic dinophysoid dinoflagellates. Phycologia 33: 97110.

JACOBSON, D. M., and D. M. ANDERSON. 1986. Thecate heterotrophic dinoflagellates: Feeding behavior and mechanisms. Journal of Phycology 22: 249-258.

James, K. J., A. Furey, M. Lehane, H. Ramstad, T. Aune, P. HovgaArd, S. Morris, W. Higman, M. SATAKE, and T. YASUMOTO. 2002a. First evidence of an extensive northern European distribution of azaspiracid poisoning (AZP) toxins in shellfish. Toxicon 40: 909-915. 
James, K. J., C. Moroney, C. Roden, M. SATake, T. Yasumoto, M. Lehane, and A. FUREY. 2003. Ubiquitous 'benign' alga emerges as the cause of shellfish contamination responsible for the human toxic syndrome, azaspiracid poisoning. Toxicon 41: 145-151.

James, K. J., M. D. Sierra, M. Lehane, A. B. Magdalena, C. Moroney, and A. FUREY. 2002b. Azaspiracid poisoning: Aetiology, toxin dynamics and new analogues in shellfish, Xth International Conference on Harmful Algal Blooms.

JEONG, H. J. 1995. The interactions between microzooplanktonic grazers and dinoflagellates causing red tides in the open coastal waters off southern California, p. 139, Oceanography. University of California San Diego.

---. 1996. The predation impact by the heterotrophic dinoflagellate Protoperidinium cf. divergens on copepod eggs in the presence of co-occurring phytoplankton prey. Journal of the Oceanological Society of Korea. Seoul 31: 144-149.

JEONG, H. J., and M. I. LATZ. 1994. Growth and grazing rates of the heterotrophic dinoflagellates Protoperidinium spp. on red tide dinoflagellates. Marine Ecology Progress Series 106: 173-185.

KJaeret, A. H., L. J. NAustvoll, and E. PaAsche. 2000. Ecology of the heterotrophic dinoflagellate genus Protoperidinium in the inner Oslofjord (Norway). Sarsia 85: 5-6.

Legrand, C., N. Johansson, G. Johnsen, K. Y. Borsheim, and E. Graneli. 2001. Phagotrophy and toxicity variation in the mixotrophic Prymnesium patelliferum (Haptophyceae). Limnology and Oceanography 46: 1208-1214.

LESSARD, E. J., and M. C. MURRELl. 1996. Distribution, abundance and size composition of heterotrophic dinoflagellates and ciliates in the Sargasso Sea near Bermuda. Deep-Sea Research (Part I, Oceanographic Research Papers) 43: 1045-1065.

LeVINSEN, H., T. G. NiELSEN, and B. W. HANSEN. 2000. Annual succession of marine pelagic protozoans in Disko Bay, West Greenland, with emphasis on winter dynamics. Marine Ecology Progress Series 206: 119-134.

LEWIS, J., J. D. DoDGE, and P. TETT. 1984. Cyst-theca relationships in some Protoperidinium species (Peridiniales) from Scottish sea lochs. J. micropalaeontol. 3: 25-34.

MARGULIS, L. 1968. Evolutionary criteria in Thallophytes: a radical alternative. Science 161: 1020-1022. 
---. 1970. Origins of Eukaryotic Cells. Yale University Press.

Moran, S., J. Silke, R. Salas, T. Chamberlan, J. Lyons, J. FlanNery, V. ThORNTON, D. Clarke, and L. Devilly. 2005. Review of Phytoplankton Monitoring 2005, p. 4-10, Proceedings of the 6th Irish Shellfish Safety Scientific Workshop. Marine Institute.

NAUSTVOLL, L. J. 2000. Prey size spectra and food preferences in thecate heterotrophic dinoflagellates. Phycologia 39: 187-198.

Pfiester, L. A., and D. M. ANDERSON. 1987. Dinoflagellate reproduction, p. 611-648. In F. J. R. Taylor [ed.], The Biology of Dinoflagellates. Botanical Monographs. Blackwell Scientific Publications.

Saldarriaga, J. F., F. J. R. TAylor, T. Cavalier-Smith, S. Menden-Deuer, and P. J. KEELING. 2004. Molecular data and the evolutionary history of the dinoflagellates. European Journal of Protistology 40: 85-111.

Saldarriaga, J. F., F. J. R. TAylor, P. J. Keeling, and T. CAVAlier-Smith. 2001. Dinoflagellate nuclear SSU rRNA Phylogeny Suggests Multiple Plastid Losses and Replacements. Journal of Molecular Evolution 53: 204-213.

SAunders, G. W., D. R. A. HiLl, J. P. SeXton, and R. A. ANDERSEN. 1997. Smallsubunit ribosomal RNA sequences from selected dinoflagellates: testing classical evolutionary hypotheses with molecular systematic methods. Plant Systematics and Evolution (Supplement) 11:237-259.

STOECKER, D. K. 1999. Mixotrophy among Dinoflagellates. Journal of Eukaryotic Microbiology 46: 397-401.

TAYLOR, F. J. R. 1976. Dinoflagellates from the International Indian Ocean Expedition: A report on material collected by the R.V. "Anton Bruun" 1963-1964. E. Schweizerbart'sche Verlagsbuchhandlung.

WALL, D., and B. DALE. 1968. Modern dinoflagellate cysts and evolution of the Peridiniales. Micropaleontology 14: 265-304.

YAMAGUCHI, A., and T. HoRIGUCHI. 2005. Molecular phylogenetic study of the heterotrophic dinoflagellate genus Protoperidinium (Dinophyceae) inferred from small subunit rRNA gene sequences. Phycological Research 53: 30-42.

YASUMOto, T., T. IgARAShi, A. FUREY, K. J. JAMES, and K. KoIKE. 2002. Discovery of the origin of azaspiracids, Xth International Conference on Harmful Algae. 


\section{Chapter 2}

Distributions and trophic relationships of Protoperidinium spp.

(Dinophyceae) and phytoplankton off the southwestern coast of Ireland in July 2003 


\section{ABSTRACT}

Little is known about the ecologies of marine thecate heterotrophic dinoflagellates in the genus Protoperidinium. One species, Protoperidinium crassipes, has been implicated as the source of the shellfish toxin azaspiracid in Ireland. This study investigated the depth and spatial distributions of Protoperidinium spp. in relation to phytoplankton species and physical oceanographic parameters in the Celtic Sea and Bantry Bay off the southwestern coast of Ireland in July 2003. Both the Celtic Sea and Bantry Bay transects were well stratified. The Irish Shelf Front was apparent as a strong salinity front separating fresher coastal waters from more saline East North Atlantic Water at the offshore stations along the Celtic Sea and Bantry Bay sections. Thirty-two species of Protoperidinium were identified from the study area. Individual Protoperidinium species had patchy distributions quite different from that of total Protoperidinium spp. In the Celtic Sea, phototrophic dinoflagellates dominated the plankton community nearshore, while diatoms dominated the offshore community. Protoperidinium species, including $P$. crassipes, Protoperidinium steinii, and Protoperidinium depressum were more abundant nearshore than offshore. The Bantry Bay section had the highest concentration and diversity of plankton in the study area. Most Protoperidinium species had the highest abundance in the nearshore waters, but with differences in depth distributions among species. The highest concentration of $P$. crassipes was at the offshore-most station. Over the whole study area, concentrations of Protoperidinium minutum, Protoperidinium pellucidum, $P$. pyriforme, and $P$. steinii were correlated with those of phototrophic dinoflagellates, although $P$. minutum and $P$. steinii also co-occurred with Chaetocerous spp. The distribution of diatom and dinoflagellate species did not always follow that of relative fluorescence, indicating that in some areas the fluorescence maximum may have been composed of picophytoplankton that is not consumed by Protoperidinium species. Plankton blooms can form rapidly in southwestern bays due to physical accumulation. Offshore monitoring of plankton abundances and distributions, when combined with observations of wind and weather conditions, could allow predictions of toxic blooms and be used to determine the potential impact to aquaculture. 


\section{INTRODUCTION}

The designation of Protoperidinium crassipes as the putative source of azaspiracid (AZA) shellfish toxin off the coast of Ireland (James et al. 2003) renewed interest in the dinoflagellate genus Protoperidinium. Even though more than 200 Protoperidinium species (Balech 1974) have been identified from waters around the world, little is known about the ecology of this genus of marine, thecate, heterotrophic species. Even less is know about the ecologies of individual Protoperidinium species.

Laboratory studies and observations of live field samples have shown that Protoperidinium consume their prey through a unique mechanism wherein the dinoflagellate envelops its prey in a pseudopod, called the pallium, in which digestion occurs external to the Protoperidinium cell (Gaines and Taylor 1984; Jacobson and Anderson 1986). This allows Protoperidinium to consume prey items as large or larger than themselves, with the size ratio of Protoperidinium to their prey tending toward 1:1 or greater, depending upon the species (Naustvoll 2000). Protoperidinium spp. thus compete with mesozooplankton for the same food resources, feeding primarily on medium to large diatoms and dinoflagellates. Small plankton, like flagellates and bacteria, are rejected prior to consumption. Most Protoperidinium spp. studied to date have been shown in the laboratory to be very selective feeders. Other Protoperidinium spp. are less selective, feeding and exhibiting positive growth rates on a diversity of diatom and dinoflagellate species (Jacobson and Anderson 1986; Jeong and Latz 1994; Buskey 1997; Naustvoll 2000; Menden-Deuer et al. 2005, Gribble, unpubl. data). Some species will even feed on copepod eggs and nauplii or detritus, or resort to cannibalism, at least in culture, if other food resources are limited (Jeong and Latz 1994; Jeong 1996; Naustvoll 2000, Gribble Unpubl. data).

The link between $P$. crassipes and AZA toxicity now appears tenuous, as production of AZA by this species has not been verified since the initial observation, and recent occurrences of azaspiracid shellfish poisoning (AZP) off the coast of Ireland have not 
been well correlated with the presence of the species (Moran et al. 2005). The previous detection of AZA in P. crassipes cells but not in other dinoflagellate species (James et al. 2003) suggests that if $P$. crassipes does not produce AZA endogenously, it may accumulate the toxin from its phytoplankton prey. In either case, understanding the ecology and trophic role of Protoperidinium spp. may be important to comprehending the dynamics of toxic phytoplankton blooms and shellfish toxicity.

The bays along the southwestern coast of Ireland are important sites of shellfish and finfish aquaculture. The region is frequently heavily impacted by harmful algal blooms causing shellfish toxicity, however, leading to harvesting closures, large economic losses, and threats to public health. The biology and hydrodynamics of some of these phytoplankton blooms (e.g., Gyrodinium aureolum, Alexandrium spp.) are now fairly well understood (Raine et al. 1990; Raine et al. 1993; McMahon et al. 1998; Raine et al. 2001). In this area, the $200 \mathrm{~m}$ isobath lies approximately $55 \mathrm{~km}$ from the coast. The bathymetry leads to a salinity and temperature front, called the Irish Shelf Front, approximately $35 \mathrm{~km}$ offshore, which strongly influences hydrodynamics and plankton community structure and dynamics (Raine and McMahon 1998). Little is known about the factors controlling the ecology of Protoperidinium in the region, however.

The ecologies of different Protoperidinium spp. are likely to be diverse and determined by the availability of preferred food types in the context of tolerances within the physical environment. As a first step towards understanding the factors that control Protoperidinium spp. populations in natural waters, the distributions of individual Protoperidinium species along the southwestern coast of Ireland during the summer of 2003 were characterized, and the relationships between Protoperidinium spp. and hydrographic conditions as well as co-occurring phytoplankton species were examined. 


\section{MATERIALS AND METHODS}

\section{Sample collection}

From 21-23 July 2003, 7 stations were sampled on a north-south transect at $9^{\circ} 17^{\prime} \mathrm{W}$ in the Celtic Sea (called the "Crease transect"), 8 stations along a southwest-northeast transect at $51^{\circ} 22^{\prime} \mathrm{N}$ from offshore to the mouth of Bantry Bay ("Bantry Bay transect"), and 1 station at Fastnet Rock at $51^{\circ} 21^{\prime} \mathrm{N}$ to $9^{\circ} 45^{\prime} \mathrm{W}$ between the Celtic Sea and Bantry Bay transects as part of a larger sampling effort along the coast of southern and western Ireland for the Biological Oceanography of Harmful Algal Blooms (BOHAB) project (Fig. 1).

At each station, a SBE 911 CTD was used to obtain hydrographic profiles of temperature, conductivity (salinity), pressure (depth) and fluorescence (chlorophyll) from the surface to $5 \mathrm{~m}$ above the bottom. These data were analyzed and plotted using Matlab 7.0.4 software. During the hydrocast at each station, Niskin bottles $(5 \mathrm{~L})$ were closed at 5 to 10 discrete depths (surface, $5 \mathrm{~m}, 10 \mathrm{~m}$, at the chlorophyll maximum layer (as determined from a real-time fluorescence profile) and 5-10 m below the chlorophyll maximum) to collect water for plankton community analysis. From each Niskin bottle, $4 \mathrm{~L}$ of water was sieved through a $20 \mu \mathrm{m}$ Nitex sieve. Using $<20 \mu \mathrm{m}$ filtered seawater, the material caught on the sieve was washed into a $15 \mathrm{~mL}$ centrifuge tube (Corning 430790, Corning, NY, USA) and the sample was brought to a volume of $14 \mathrm{~mL}$. Samples were preserved with formalin ( $5 \%$ final concentration), and stored at $4^{\circ} \mathrm{C}$ until analysis.

\section{Plankton counts and species identification}

Plankton species were counted in a subset of the sampled stations (6 stations along the Crease transect, 6 stations along the Bantry Bay transect, and Fastnet Rock) using a traditional settling method (Hasle 1978). The sample was mixed well before $3.7 \mathrm{~mL}$ to $7.4 \mathrm{~mL}$ (the equivalent of 1 to $2 \mathrm{~L}$ of whole water) was withdrawn by pipette and settled overnight in Hydro-Bios Utermöhl's settling chambers (Campinex, Ltd., Nova Scotia, 
Figure 1.

Map of study area off the coast of southwestern Ireland. Dots show locations of stations sampled. 


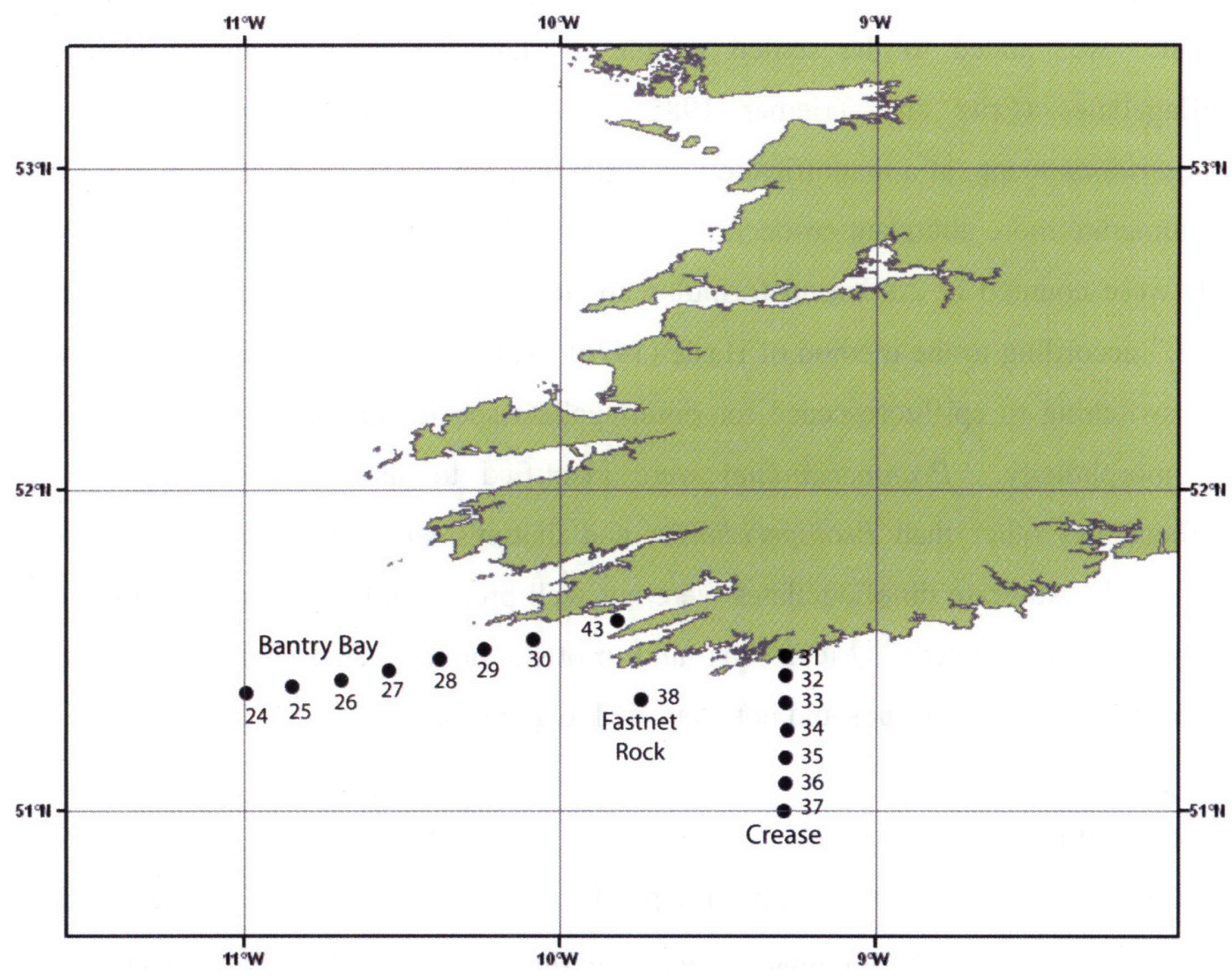


Canada). To aid in identification of dinoflagellate species, $1 \mathrm{hr}$. prior to counting $4 \mu \mathrm{l}$ of Calcofluor White M2R (Polysciences, Inc., Warrington, PA, USA) at a concentration of 1 $\mathrm{mg} \mathrm{mL} \mathrm{m}^{-1}$ was added to the settled sample to stain the cellulose thecal plates of dinoflagellates (Fritz and Triemer 1985). The entire chamber was counted for Protoperidinium spp. at a magnification of $200 \mathrm{X}$ on a Zeiss IM 35 inverted microscope. To enumerate more abundant co-occurring phytoplankton species, multiple diameters or fields were counted at $200 \mathrm{X}$ and formulas applied to determine cell concentrations in cells $\mathrm{L}^{-1}$ according to the method of Hasle (1978). All counts were made under tungsten light, switching to epifluorescence for dinoflagellate species identification using thecal plate morphology. Protoperidinium were identified to species level. Species of dinoflagellates other than Protoperidinium and diatoms were identified to species or genus level. Athecate dinoflagellates were not well preserved by formalin-fixation, and thus were not counted. Metazoans and protists other than dinoflagellates were categorized into major groups and not identified to genus or species.

\section{Species relationships}

Because many Protoperidinium spp. are specific feeders, linear regression was used to find correlations between individual Protoperidinium species and individual or groups of phototrophic diatoms and dinoflagellates to try to determine potential specific predatorprey relationships. Since a particular Protoperidinium sp. might be expected to occur only where its preferred prey species was present, but that prey species would not only occur where the predatory Protoperidinium spp. was present, those samples where the given Protoperidinium sp. was not detected were excluded from the analyses.

\section{RESULTS}

\section{Hydrography}

\section{Crease section}

The Crease section exhibited well-stratified conditions offshore with more mixed conditions closer to the coast (Fig. 2). Surface to bottom temperatures differed by $6^{\circ} \mathrm{C}$, 
with a distinct thermocline at ca. $25-30 \mathrm{~m}$; a cold sub-thermocline pool was present offshore (Fig. 2A). Colder, less saline and less dense water near the coast, at stations 31 and 32, extending ca. $20 \mathrm{~km}$ offshore in the upper $20 \mathrm{~m}$, was indicative of a fresh coastal band in the surface waters (Fig. 2B). The Irish Shelf Front was apparent as a strong salinity front separating East North Atlantic Water from the coastal water below the halocline at ca. $51.2^{\circ}$ N. Salinity $>35.3$ psu typically demarcates this front. The density structure along the Crease section appeared to be dominated by temperature rather than salinity (Fig. 2C). Strong bottom density fronts were evident at ca. $51.4^{\circ} \mathrm{N}$, indicating a flow from east to west through this section at that latitude.

Relative fluorescence was measured as a proxy of chlorophyll concentration. Relative fluorescence on the Crease Section was generally below $0.18 \mathrm{rfu}$, but discrete patches of higher fluorescence, near $0.2 \mathrm{rfu}$, were apparent in the thermocline at $51.35^{\circ} \mathrm{N}$ and $51.15^{\circ} \mathrm{N}$. The highest fluorescence, greater than $0.22 \mathrm{rfu}$, was seen in discrete patches at the surface near shore and in the lower portion of the thermocline at the offshore-most stations, between $51^{\circ} \mathrm{N}$ and $51.1^{\circ} \mathrm{N}$.

\section{Fastnet Rock}

A single station was sampled at Fastnet Rock, between the Bantry Bay and Crease sections. The temperature, salinity, and relative fluorescence profiles for Fastnet Rock are shown in Figure 3. A strong thermocline was present at $22-28 \mathrm{~m}$, the same depth as the sub-surface maximum in relative fluorescence (ca. $0.2 \mathrm{rfu}$ ). The salinity profile shows that, like at the nearshore stations on the Crease section, there was fairly fresh water of $34.8 \mathrm{psu}$ at the surface, with only a small increase to $34.9 \mathrm{psu}$ at the thermocline and a sharp increase below $60 \mathrm{~m}$ to a maximum of $>35 \mathrm{psu}$ at the bottom of the sampled profile at $70 \mathrm{~m}$. 
Figure 2.

Cross sectional plots of hydrographic parameters along Crease transect, including (A) temperature, (B) salinity, (C) density, and (D) relative fluorescence. 

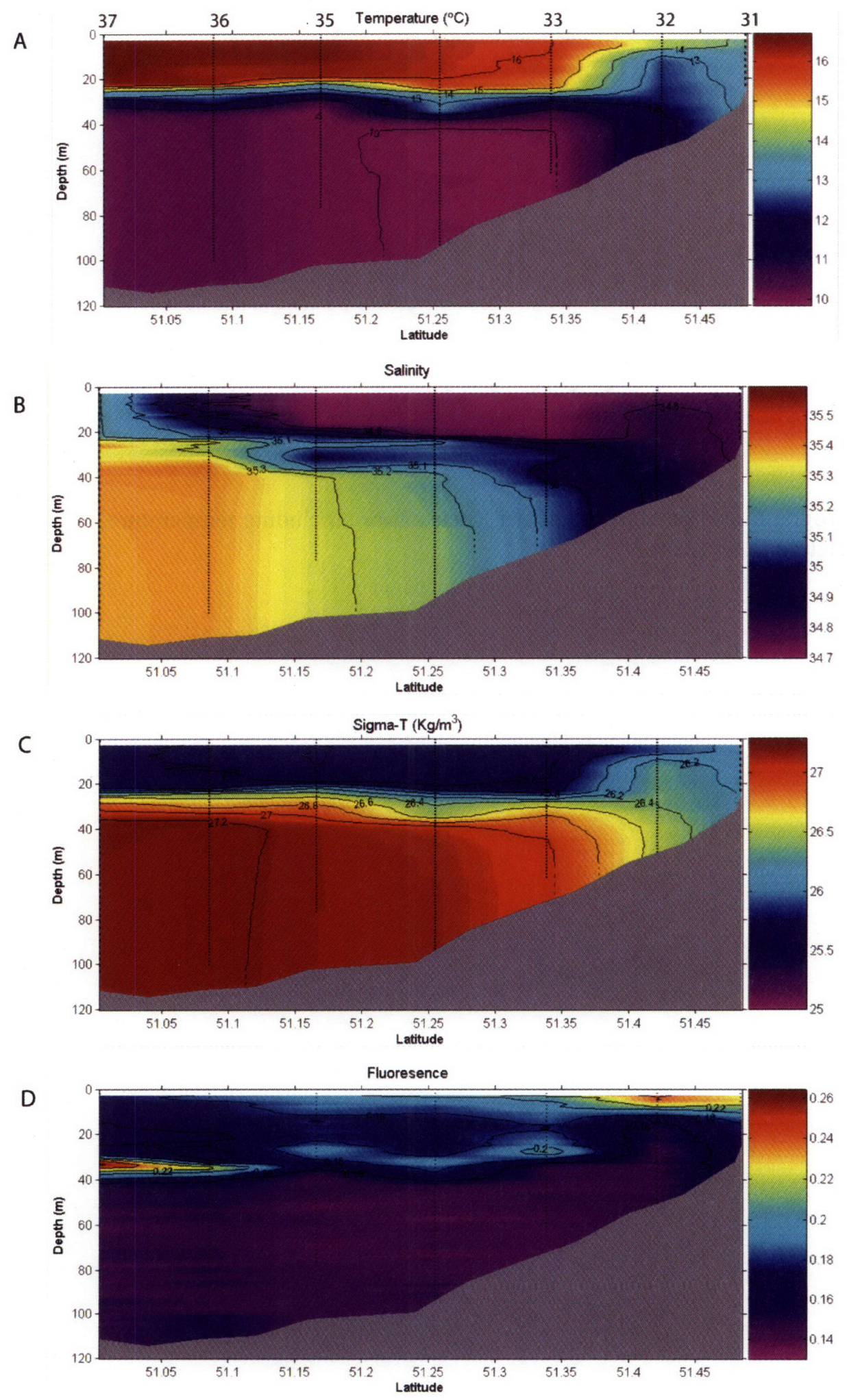
Figure 3.

Profiles of hydrographic parameters at Fastnet Rock station, including temperature, salinity, and relative fluorescence. 


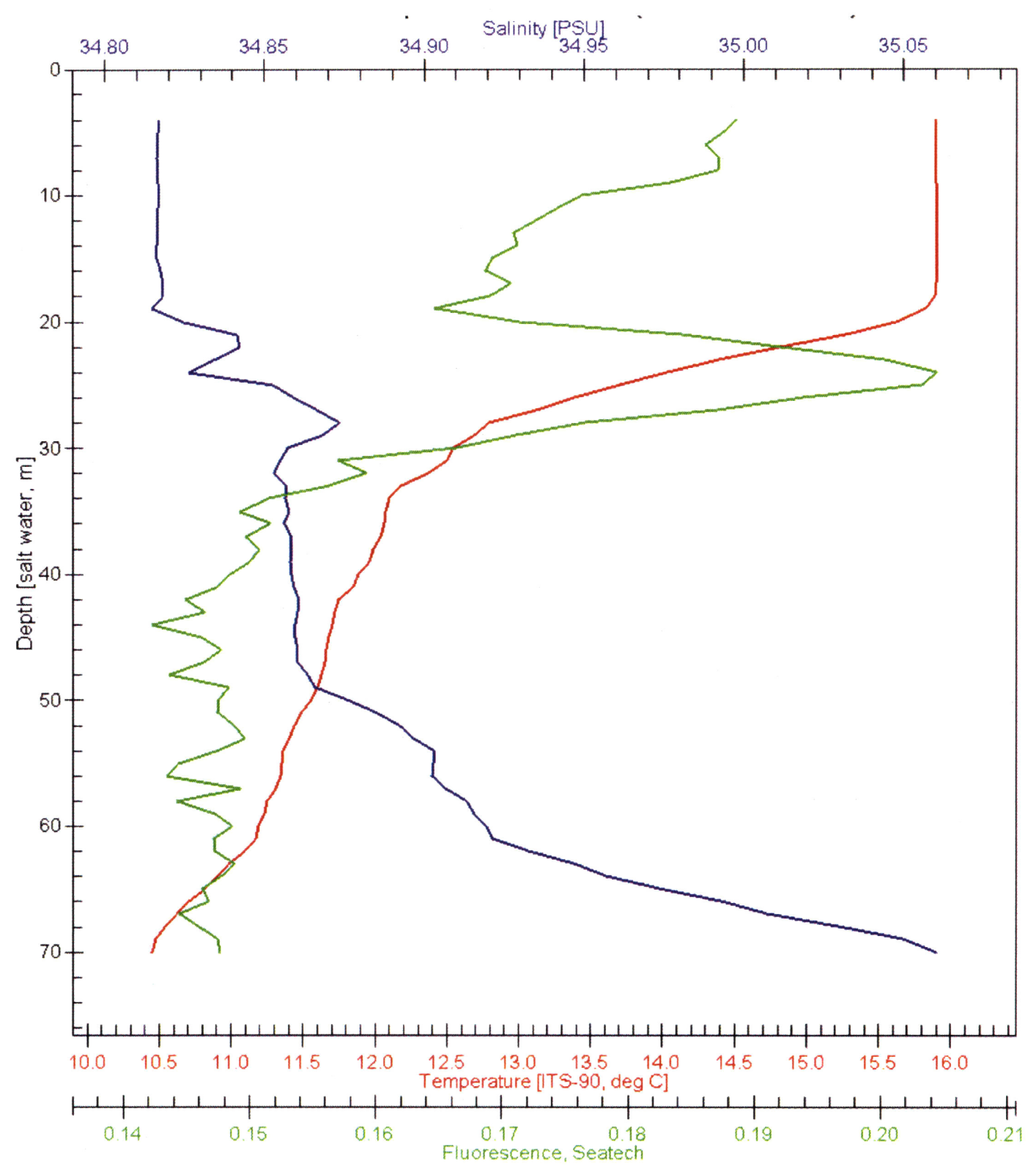


Figure 4.

Cross sectional plots of hydrographic parameters along Bantry Bay transect, including (A) temperature, (B) salinity, (C) density, and (D) relative fluorescence. 

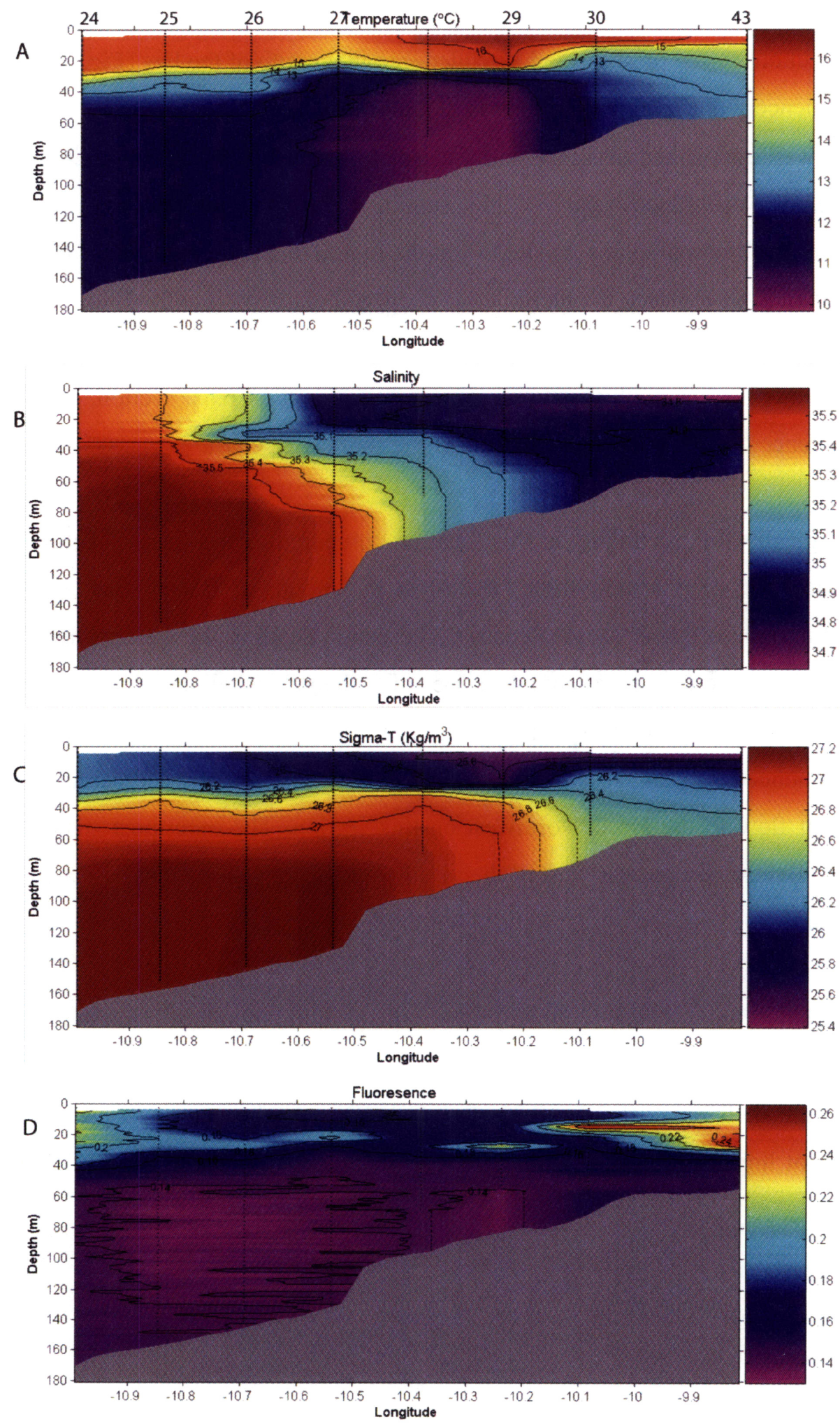


\section{Bantry Bay section}

The Bantry Bay section started offshore and extended into the mouth of the bay (Fig. 4). Coastal water influence was apparent, particularly at the eastern end of the section.

Stratification was well established along the entire transect. As along the Crease section, there was a temperature difference of ca. $6^{\circ} \mathrm{C}$ between the surface and bottom waters (Fig. 4A). The thermocline was relatively shallow at the mouth of Bantry Bay, at ca. 10 $\mathrm{m}$. Moving west along the transect, the thermocline deepened, narrowing to $25-30 \mathrm{~m}$ between $10.2^{\circ} \mathrm{W}$ and $10.4^{\circ} \mathrm{W}$ and then widened and further deepened to ca. $30-40 \mathrm{~m}$ at $11.0^{\circ} \mathrm{W}$. The sub-thermocline pool was slightly warmer than on the Crease section, reflecting the influence of the Shelf Edge Current off the south west coast.

Salinities were typically $0.1 \mathrm{psu}$ higher at this location compared to the Crease section (Fig. 4B). Surface and deep waters were freshest at the mouth of Bantry Bay, and salinity increased moving offshore, to greater than $35.5 \mathrm{psu}$ at depth at the western-most station. The Irish Shelf Front was present as a series of $\mathbf{S}$ shaped isohalines centered on $10.5^{\circ} \mathrm{W}$. As on the Crease section, temperature dominated the observed density structure (Fig. 4C). Pronounced bottom fronts were evident at ca. $10.2^{\circ} \mathrm{W}$, indicating a geostrophic current flow to the North/Northwest on this section. The outermost station (station 24) on the Bantry section was west of the salinity and density shifts that indicated the Irish Shelf Front.

Patches of high relative fluorescence $(0.26 \mathrm{rfu})$ were evident in the mouth of Bantry Bay, between $9.8^{\circ} \mathrm{W}$ to $10.1^{\circ} \mathrm{W}$, and in discrete patches in the thermocline as the section extended west to the shelf break $(0.20-0.22 \mathrm{rfu})$ (Fig. 4D). At the outermost station, there was a patch of high fluorescence above the thermocline, in the upper $30 \mathrm{~m}$ of the water column. 


\section{Plankton distributions}

Thirty-two species of Protoperidinium were identified from the samples analyzed (Table 1). A diversity of other dinoflagellate species was present in the study area, with 37 autotrophic or mixotrophic species or genera identified, and 11 species or genera of heterotrophic dinoflagellates other than Protoperidinium present (Table 2). Ceratium, Dinophysis, and Prorocentrum species were among the most abundant phototrophic dinoflagellates. Twenty species or genera of diatoms were found (Table 2), with Rhizoselinia spp., Probescia alata, Pseudo-nitzchia spp. and Nitzchia spp. as the most abundant and widely distributed.

\section{Crease Section Plankton}

The most offshore station (station 37) on the Crease Section, to the south of the Irish Shelf Front, had relatively low concentrations of phytoplankton compared with the rest of the section. North of the Irish Shelf Front, the plankton community was dominated by diatoms in the offshore stratified surface waters (Fig. 5A-B), but inshore along the transect transitioned to a dinoflagellate-dominated community (Fig. 6A) in the area of upwelling. The deep offshore fluorescence maximum on the Crease section (Fig. 2D) was likely due to picoplankton, as large phototrophs were in low abundance at this station, relative to the rest of the section.

The concentration of total diatoms along the Crease section was largely determined by the abundance of the dominant diatom species, Probescia alata (Fig. 5B). Concentrations of $P$. alata were generally highest in the surface waters and increased from nearshore to offshore, exclusive of station 37. At station 36, a high concentration of

$P$. alata $\left(2689\right.$ cells $\left.\mathrm{L}^{-1}\right)$ was found at a depth of $42 \mathrm{~m}$, well below the thermocline.

In contrast to the distribution of diatoms, total phototrophic dinoflagellates were more abundant near shore and decreased moving south and offshore along the transect (Fig. 6A). Phototrophic dinoflagellates were most abundant in the surface waters, but were 
also present at depths near the thermocline at stations in the middle of the transect. The dinoflagellate community along the Crease section was dominated by Dinophysis acuta (Fig. 6B), Ceratium lineatum (Fig. 6C) and Prorocentrum spp. (Fig. 6D). Dinophysis acuta was most abundant nearshore and at the surface, with a maximum concentration of 645 cells $\mathrm{L}^{-1}$. Ceratium lineatum was most abundant at the nearshore stations, primarily in the surface waters, although high concentrations were found at depth at stations 33 and 34 , in the layer of highest fluorescence, with a maximum of 306 cells $\mathrm{L}^{-1}$ at $35 \mathrm{~m}$. Concentrations of Prorocentrum spp. were highest in the surface waters, particularly at the nearshore stations.

Concentrations of total Protoperidinium spp. were highest nearshore, and low in the two most southern and offshore stations (Fig. 7A). At the most inshore stations, total Protoperidinium spp. were distributed through the water column. Protoperidinium crassipes was not detected in the offshore waters, and appeared confined to the nearshore stations along the Crease section at concentrations never exceeding 4 cells $\mathrm{L}^{-1}$ (Fig. 7B). Protoperidinium pyriforme was distributed throughout the water column at concentrations below 10 cells $\mathrm{L}^{-1}$ at the nearshore stations (Fig. 7C). Similarly, P. steinii was found only at the nearshore stations, but was in slightly higher concentrations in the surface waters than deep, with a maximum concentration of 17 cells $\mathrm{L}^{-1}$ (Fig. 7D). In contrast, $P$. depressum was limited primarily to deeper waters at or below the thermocline, and was only found in surface waters at the nearshore station. Concentrations of $P$. depressum did not exceed 25 cells $\mathrm{L}^{-1}$ in any sample (Fig. 7E).

Thecate heterotrophic dinoflagellates other than Protoperidinium spp. were generally absent from the Crease section. The athecate heterotrophic dinoflagellate Noctiluca scintillans was comparatively abundant in the surface waters, except at the most offshore station, outside the Irish Shelf Front (Fig. 8A). Conversely, copepods (Fig. 8B) and copepod nauplii (Fig. 8C) were slightly more abundant at the thermocline and near the 
Table 1. Protoperidinium species found in the study area.

P. achromaticum (Levander) Balech

$P$. bipes (Paulsen) Balech

P. brevipes (Paulsen) Balech

$P$. cerasus (Paulsen) Balech

P. conicoides (Paulsen) Balech

$P$. conicum (Gran) Balech

P. crassipes (Kofoid) Balech

$P$. curvipes (Ostenfeld) Balech

$P$. depressum (Bailey) Balech

$P$. diabolum (Cleve) Balech

$P$. divergens (Ehrenberg) Balech

$P$. excentricum (Paulsen) Balech

$P$. globulum (Stein) Balech

$P$. granii (Ostenfeld) Balech

P. leonis (Pavillard) Balech

P. marielbourae (Paulsen) Balech

$P$. minutum (Kofoid) Loeblich III

P. mite (Pavillard) Balech

$P$. oblongum (Aurivillius) Parke and Dodge

$P$. oceanicum (VanHöffen) Balech

$P$. ovatum Pouchet

P. pallidum (Ostenfeld) Balech

$P$. pellucidum Bergh

$P$. pentagonum (Gran) Balech

$P$. punctulatum (Paulsen) Balech

$P$. pyriforme (Paulsen) Balech

$P$. cf. pyrum (Balech) Balech

$P$. steinii (Jorgensen) Balech

P. subcurvipes (Lebour) Balech

P. subinerme (Paulsen) Loeblich III

P. thorianum (Paulsen) Balech

P. thulense (Balech) Balech 
Table 2. Plankton species found in the study area, including metazoa.

Phototrophic Dinoflagellates

Alexandrium sp. Halim

Amphidiniopsis sp. Woloszynska

Amphidoma sp. Stein

Amylax sp. Meunier

Ceratium furca (Ehrenberg) Claparède and Lachmann

Ceratium fusus (Ehrenberg) Dujardin

Ceratium hexicantum Gourret

Ceratium horridum (Cleve) Gran

Ceratium lineatum (Ehrenberg) Cleve

Ceratium longipes (Bailey) Gran

Ceratium macroceros (Ehrenberg) Cleve

Ceratium minutum Jorgensen

Ceratium setaceum Jorgensen

Ceratium trichoceros (Ehrenberg) Kofoid

Ceratium tripos (O.F. Müller) Nitzsch

Corythrodinium sp. Lobelich Jr. and Loeblich III

Dinophysis acuminata Claparède and Lachmann

Dinophysis acuta Ehrenberg

Dinophysis dens Pavillard

Dinophysis naustum (Stein) Parke and Dixon

Dinophysis norvegica Claparède and Lachmann

Dinophysis ovum Schutt

Dinophysis punctata Jorgensen

Dinophysis rotundata Claparède and Lachmann

Dinophysis sp. Ehrenberg

Dinophysis tripos Gourret

Gonyaulax sp. Diesing

Gymnodinium sp. Stein

Lingulodinium polyedrum (Stein) Dodge

Naked dinoflagellate spp.

Podolampas palmipes Stein

Prorocentrum gracile Schütt

Prorocentrum micans Ehrenberg

Prorocentrum sp. Ehrenberg

Pyrocystis lunula (Schütt) Schütt

Scrippsiella sp. Balech ex Loeblich III

Triadinium polyedricum (Pouchet) Dodge

\section{Heterotrophic Dinoflagellates}

Diplopsalis lenticula Bergh

Diplopsalis sp. Bergh

Dissodinium sp. Abé

Dissodium asymmetricum (Magin) Lobelich

Noctiluca scintillans (Macartney) Kofoid and Swezy

Oblea rotunda (Lebour) Balech ex Sournia

Preperidinium lenticulatum (syn. Zygabikodinium lenticula) (Pavillard) Elbrächter Preperidinium sp. Mangin

Pronoctiluca sp. Fabre-Domergue

Pyrocystis lunula (Schütt) Schütt 


\section{Diatoms}

Asterionella sp. Hassall

Centric diatom spp.

Chaetocerous spp. Ehrenberg

Cocinodiscus spp. (Ehrenberg) Hasle and Sims

Leptocylindrus danicus Cleve

Leptocylindrus mediteraneum (H. Peragallo) Hasle

Leptocylindrus sp. Cleve

Melosira sp. C.A. Agardh

Navicula sp. Bory

Pseudo-nitzchia spp.

Nitzchia spp.

Paralia sulcata (Ehrenberg) Cleve

Pennate diatom spp.

Probescia alata (Brightwell) Sudström

Pseudogunardia sp. von Stoch

Rhizoselinia spp. Brightwell

Rhizoselinia deleticulata Cleve

Skeletonema sp. Greville

Thallasiosira sp. (Cleve) Hasle

\section{Chromophytes}

Halosphaera parkeae Boalch and Mommaerts

$\underline{\text { Metazoa }}$

Copepods

Copepod nauplii

Larve

Protists

Ciliates

Coccolithophores

Dictyocha spp.

Foraminifera

Radiolarians

Tintinids 
Figure 5.

Concentrations of diatoms along Crease Section shown in cells $\mathrm{L}^{-1}$ : (A) Total diatoms, (B) Probescia alata. 


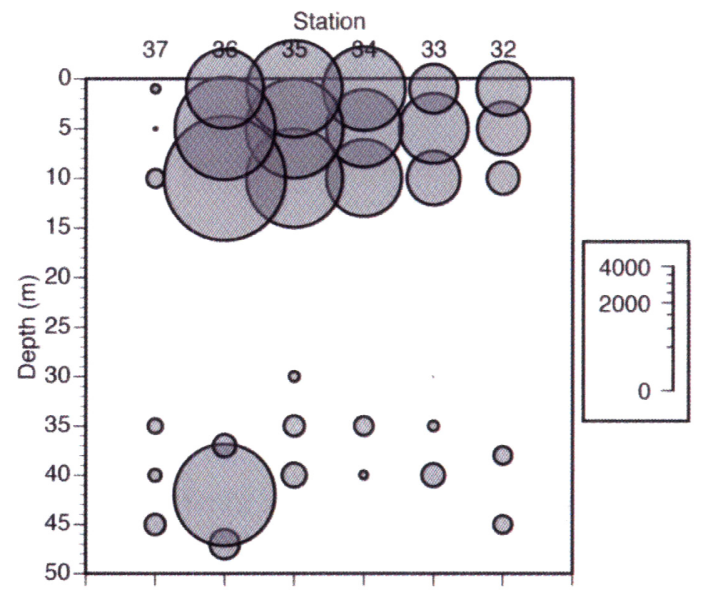

A. Total Diatoms

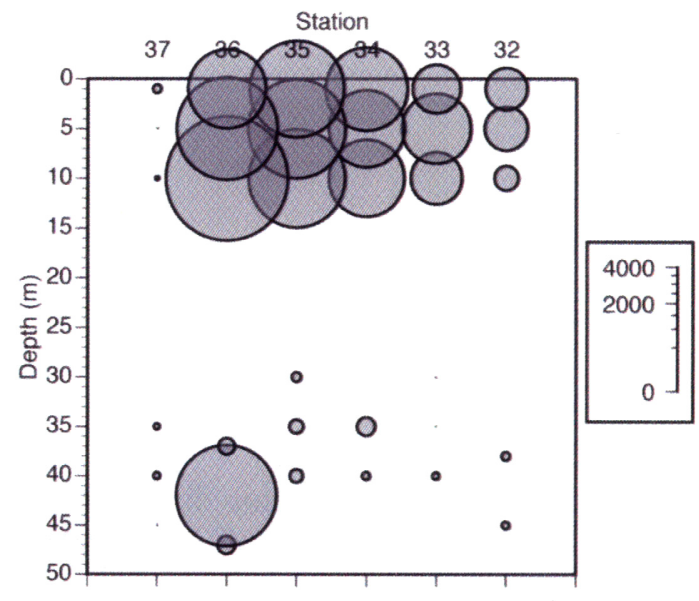

B. Probescia alata 
Figure 6.

Concentrations of phototrophic dinoflagellates along Crease Section shown in cells $\mathrm{L}^{-1}$ : (A) Total phototrophic dinoflagellates, (B) Dinophysis acuta, (C) Ceratium lineatum, (D) Total Prorocentrum spp. 


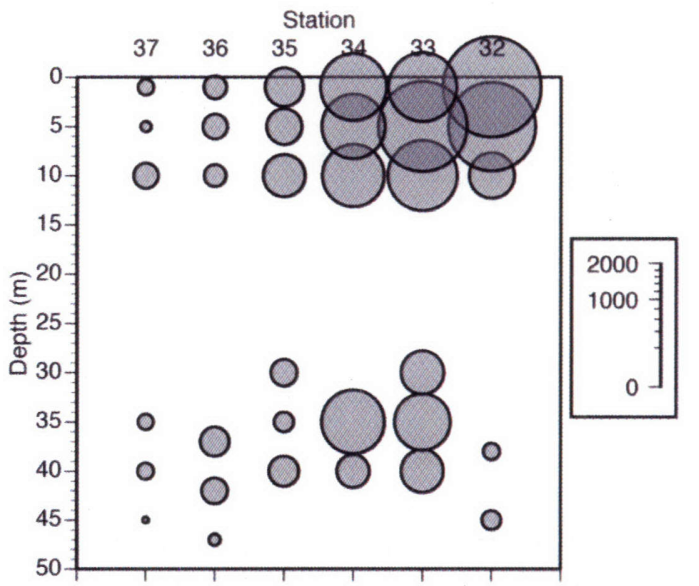

A. Total Dinoflagellates

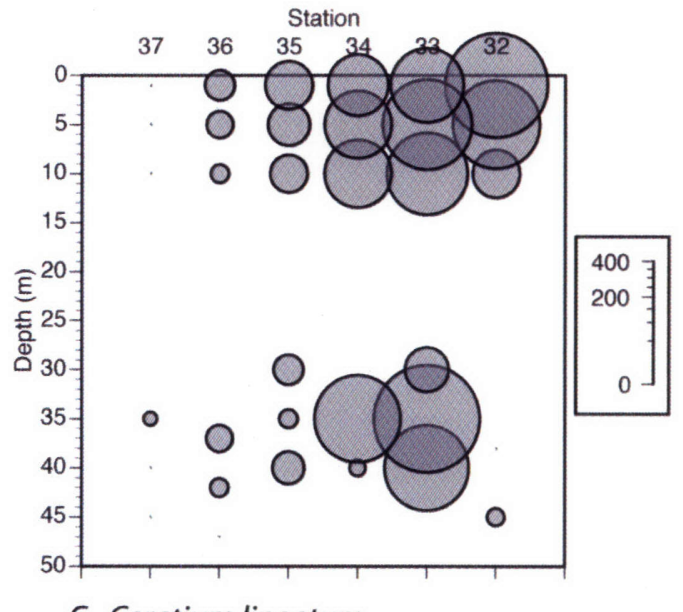

C. Ceratium lineatum

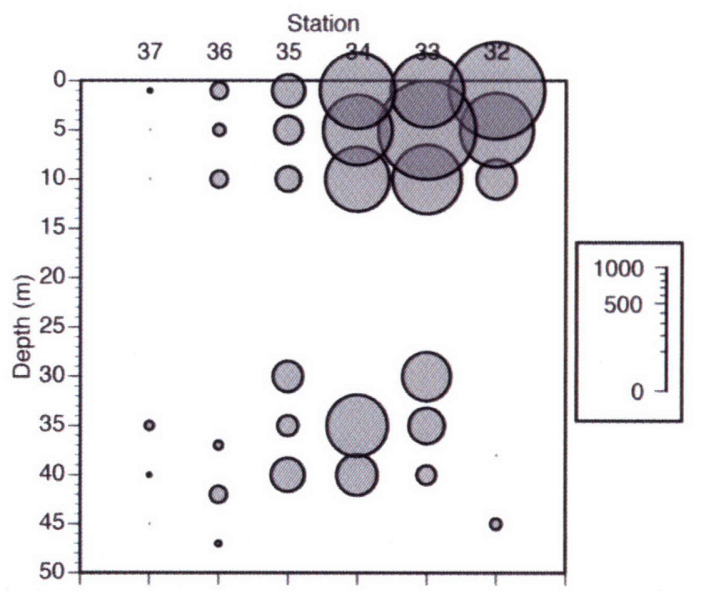

B. Dinophysis acuta

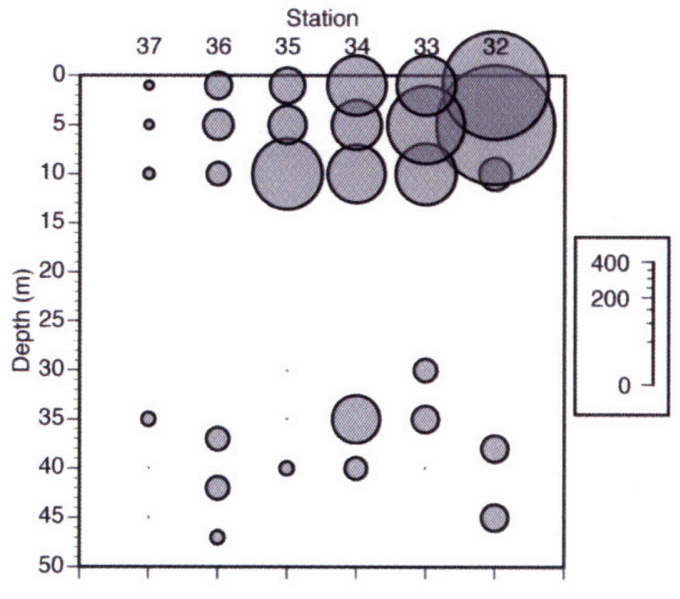

D. Total Prorocentrumspp. 
Figure 7.

Concentrations of Protoperidinium spp. along Crease Section shown in cells $\mathrm{L}^{-1}$ : (A) Total Protoperidinium, (B) Protoperidinium crassipes, (C) Protoperidinium pyriforme, (D) Protoperidinium steinii, (E) Protoperidinium depressum. 


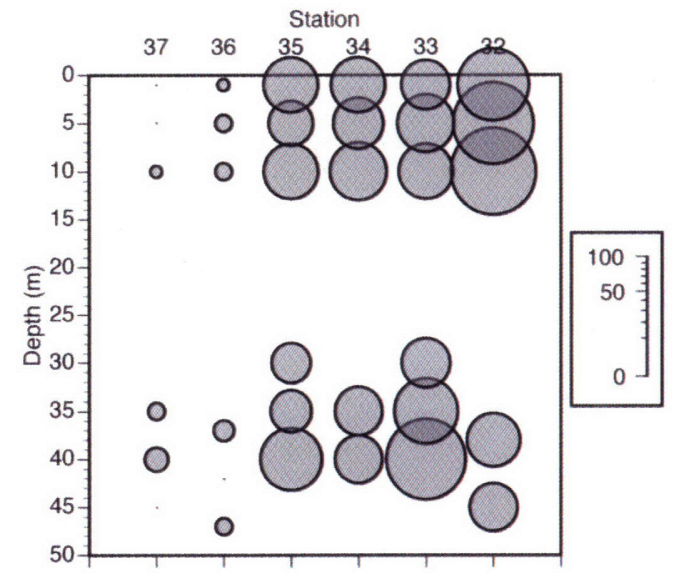

A. Total Protoperidinium

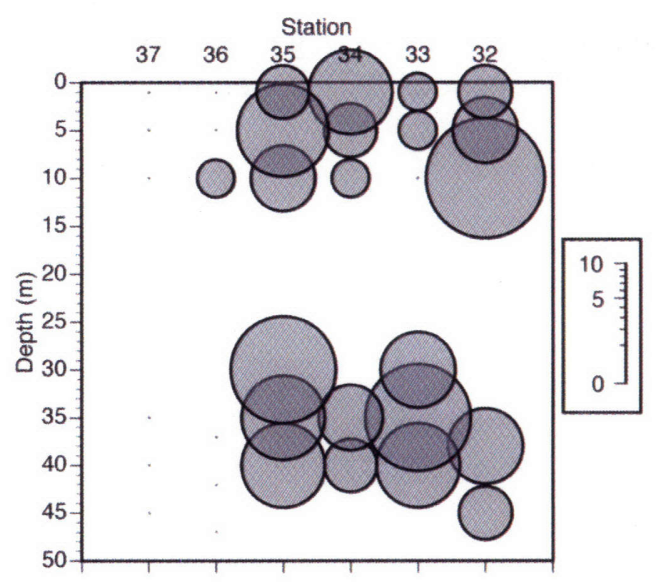

C. Protoperidinium pyriforme

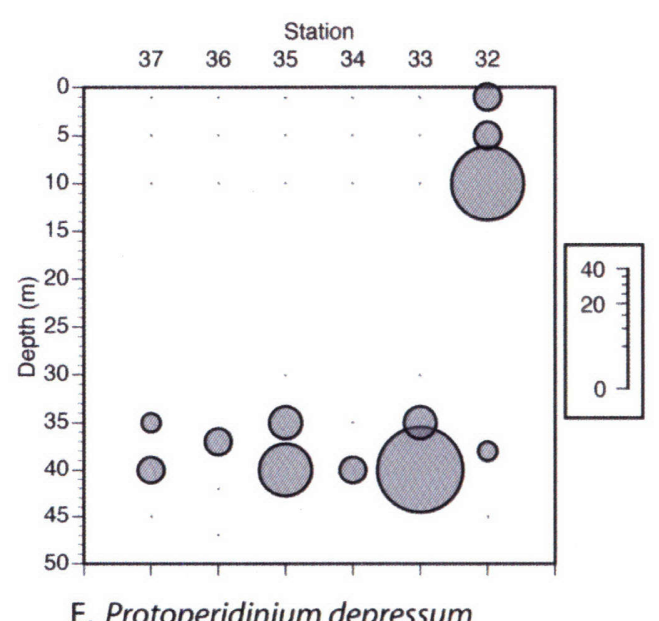

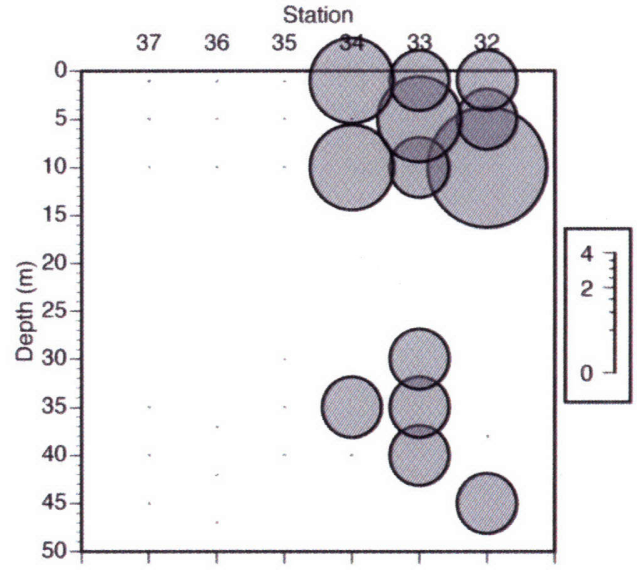

B. Protoperidinium crassipes

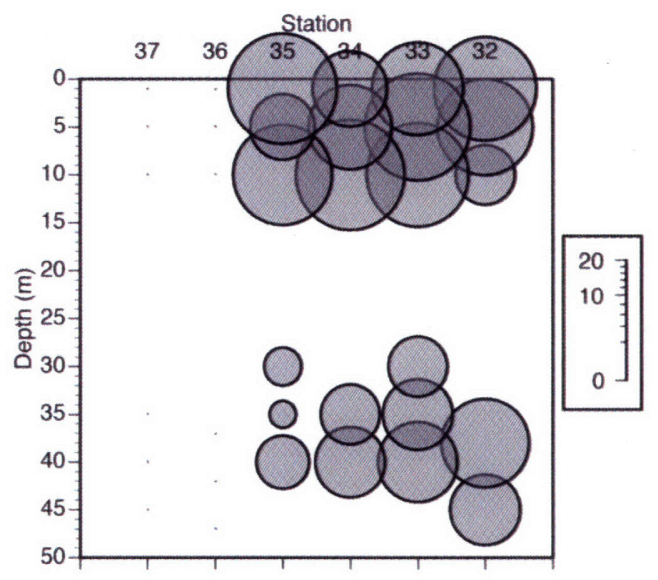

D. Protoperidinium steinii 
Figure 8.

Concentrations of other heterotrophic dinoflagellates and copepods along Crease Section shown in individuals $\mathrm{L}^{-1}$ : (A) Noctiluca scintillans, (B) Copepods, (C) Copepod nauplii 


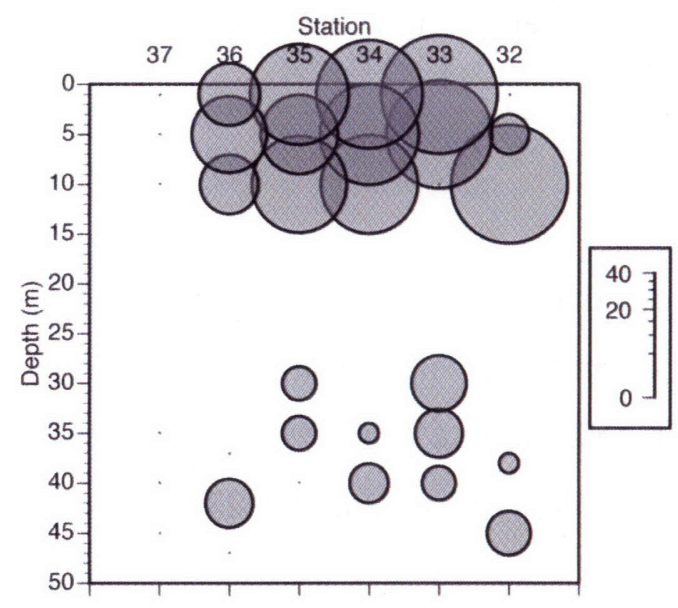

A. Noctiluca scintillans

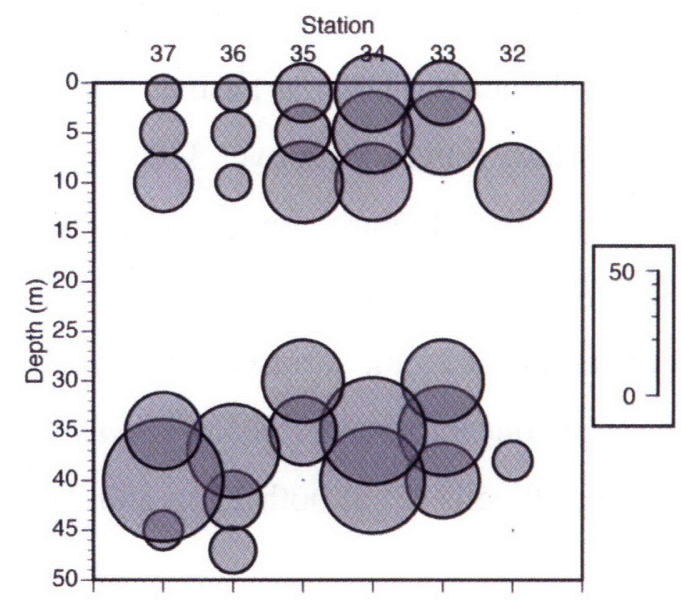

B. Copepods

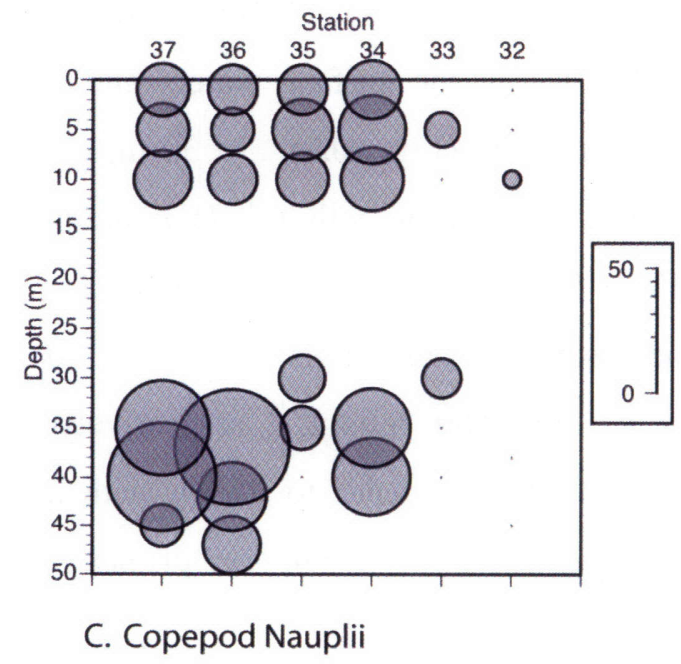


deep fluorescence maximum layer than in the surface waters, and increased in abundance moving from nearshore to offshore.

\section{Fastnet Rock}

There were relatively high concentrations of both diatoms and dinoflagellates at the Fastnet Rock station. The concentration of total diatoms was highest in surface waters, with a maximum concentration of more than 3450 cells $\mathrm{L}^{-1}$ at a depth of $5 \mathrm{~m}$ (Fig. 9A). Total diatoms were slightly less abundant at the chlorophyll maximum, with 2300 cells $\mathrm{L}^{-}$ ${ }^{1}$ at $25 \mathrm{~m}$, and dropped to 450 cells $\mathrm{L}^{-1}$ at $30 \mathrm{~m}$.

As on the Crease section, the profiles of individual diatom species varied from that of total diatoms. Probescia alata (Fig. 9B) was the most abundant diatom at Fastnet Rock, and dictated the concentration of total diatoms in the surface waters, with over 3400 cells $\mathrm{L}^{-1}$ at $5 \mathrm{~m}$. All of the other prevalent diatom species had their highest concentrations at depth, however. Pseudo-nitzchia spp. (Fig. 9C), Rhizoselinia spp. (Fig. 9D), and Navicula spp. (Fig. 9E), all had their highest concentrations at $25 \mathrm{~m}$, corresponding with the thermocline and the maximum in fluorescence. The concentration of Leptocylindrus spp. (Fig. 9F) was also highest at the thermocline, near 70 cells $\mathrm{L}^{-1}$ at both $25 \mathrm{~m}$ and 31 m.

The concentration of total phototrophic dinoflagellate species at Fastnet Rock increased from the surface to the thermocline, with 300 cells $\mathrm{L}^{-1}$ in the surface waters and a concentration of more than 1000 cells L $^{-1}$ at a depth of $25 \mathrm{~m}$ (Fig. 10A). At $30 \mathrm{~m}$, the concentration of total phototrophic dinoflagellates was less than 40 cells $\mathrm{L}^{-1}$. Dinophysis acuta (Fig. 10B) and Ceratium lineatum (Fig. 10C) were the most abundant dinoflagellates species, and both species had increasing concentrations with depth to maximum concentrations at $25 \mathrm{~m}$ of 386 cells $\mathrm{L}^{-1}$ and 480 cells $\mathrm{L}^{-1}$, respectively. Dinophysis acuminata cell concentrations also increased with depth to $25 \mathrm{~m}$, with a maximum of 33 cells L ${ }^{-1}$ (Fig. 10D). Conversely, Prorocentrum spp., composed primarily 
of $P$. micans, reached maximum concentrations above the thermocline, reaching 184 cells $\mathrm{L}^{-1}$ at $10 \mathrm{~m}$ (Fig. 10E).

Protoperidinium spp. had a low relative abundance, compared with other dinoflagellates and with diatoms. Concentrations of total Protoperidinium spp. at Fastnet Rock were highest at $25 \mathrm{~m}\left(54\right.$ cells L$\left.^{-1}\right)$ and were elevated below the thermocline compared with the surface waters (Fig. 11A). While P. crassipes (Fig. 11B), P. depressum (Fig. 11C), and P. pyriforme (Fig. 11D), all reached their highest abundances (from 6-15 cells $\mathrm{L}^{-1}$ ) at 25 or $31 \mathrm{~m}, P$. steinii (Fig. 11E) was most abundant in the surface waters, with a maximum concentration of 18 cells L $\mathrm{L}^{-1}$ at $10 \mathrm{~m}$.

Protoperidinium spp. were the most common heterotrophic dinoflagellates found at Fastnet Rock, but Noctiluca scintillans and Oblea rotunda were also present. Noctiluca scintillans was found throughout the water column, and was in slightly higher concentrations in the surface waters than at depth, with a maximum of 28 cells $\mathrm{L}^{-1}$ at $5 \mathrm{~m}$ (Fig. 12A). The thecate heterotroph $O$. rotunda was in low concentrations in the surface

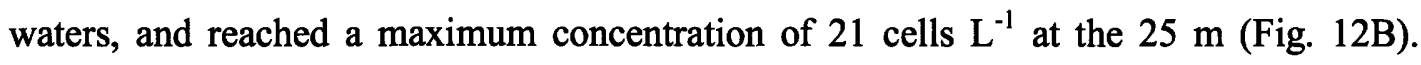
Copepods and copepod nauplii were distributed through the water column at the station in abundances similar to those along the Crease section (Figs. 12C-D).

\section{Bantry Bay Section}

The Bantry Bay transect had higher concentrations of both diatoms and dinoflagellates than did either the Crease section or Fastnet Rock. Total diatom abundances were highest in the mouth of the bay with a maximum of ca. 53,300 cells $\mathrm{L}^{-1}$ at $1 \mathrm{~m}$ depth, and at the offshore-most station where the maximum concentration was ca. 46,800 cells L $^{-1}$, with lower concentrations along the center of the section (Fig. 13A). The diatom community nearshore was dominated by Probescia alata (Fig. 13B), Pseudo-nitzchia spp. (Fig 13C), Rhizoselinia spp. (Fig. 13D), and Leptocylindrus spp. (Fig. 13E). At the western-most station, those three genera were nearly absent, and small Nitzchia spp. 
Figure 9.

Concentrations of diatoms at Fastnet Rock Station shown in cells $\mathrm{L}^{-1}$ : (A) Total diatoms, (B) Probescia alata, (C) Pseudo-nitzchia spp., (D) Rhizoselinia spp. (E) Navicula spp., (F) Leptocylindrus spp. 


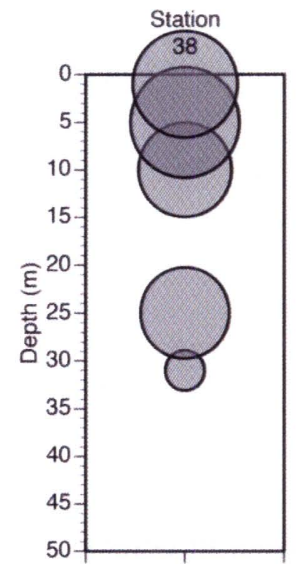

A. Total Diatoms

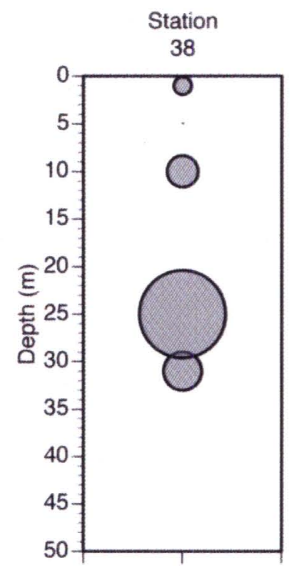

D. Rhizoselinia spp.

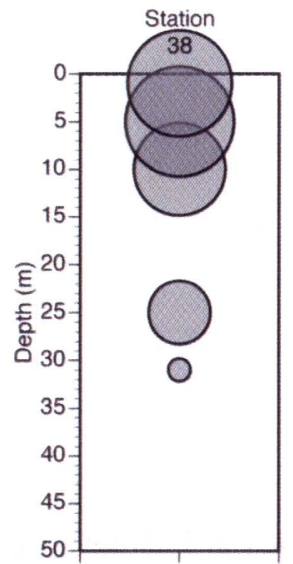

B. Probescia alata

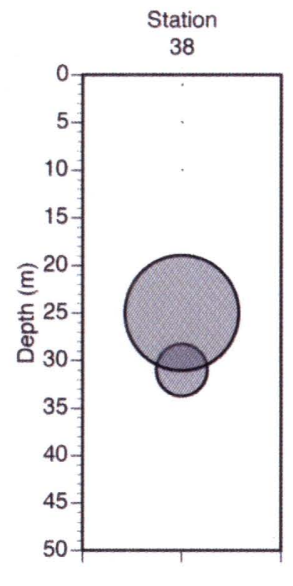

E. Navicula spp.

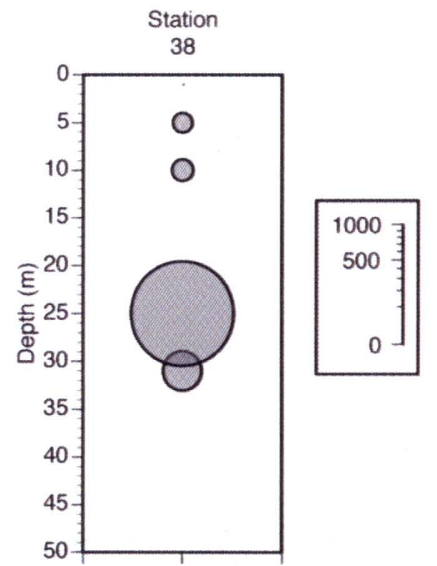

C. Pseudo-nitzchia spp.

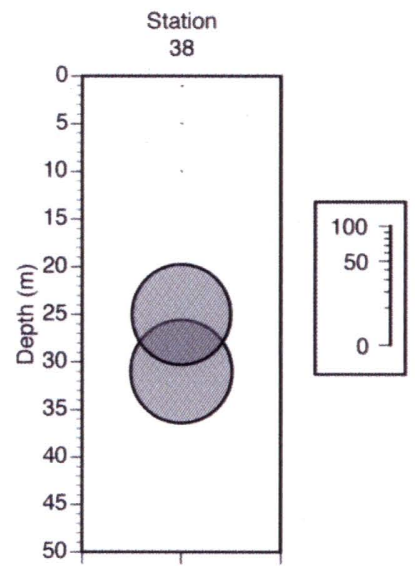

F. Leptocylindrus spp. 
Figure 10.

Concentrations of phototrophic dinoflagellates at Fastnet Rock station shown in cells $\mathrm{L}^{-1}$ : (A) Total phototrophic dinoflagellates, (B) Dinophysis acuta, (C) Ceratium lineatum, (D) Dinophysis acuminata, (E) Total Prorocentrum spp. 


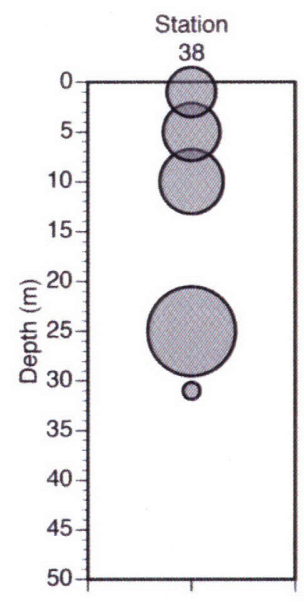

A. Total Dinoflagellates

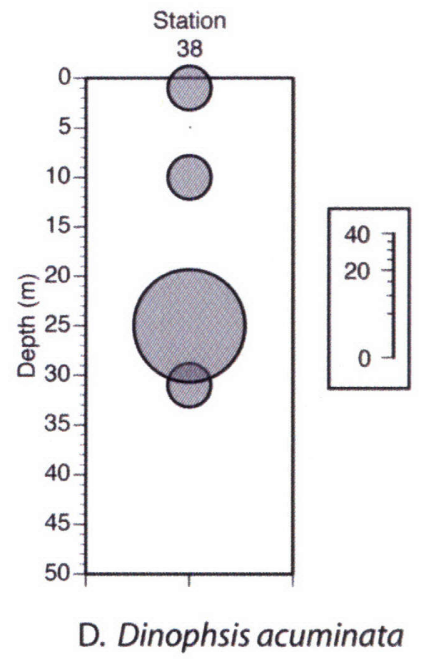

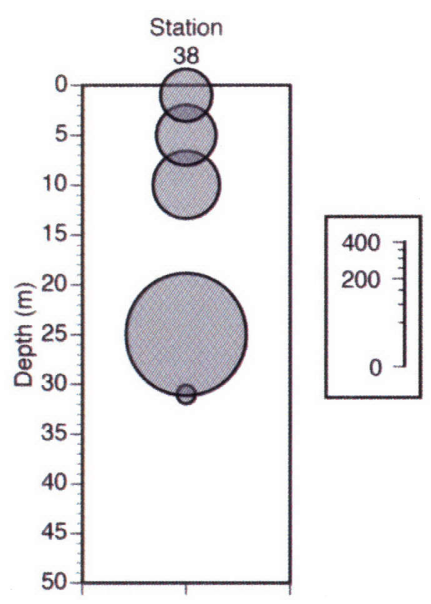

B. Dinophysis acuta

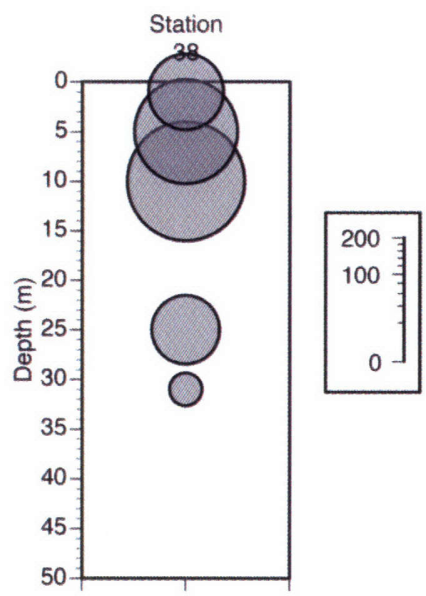

E. Total Prorocentrum spp.

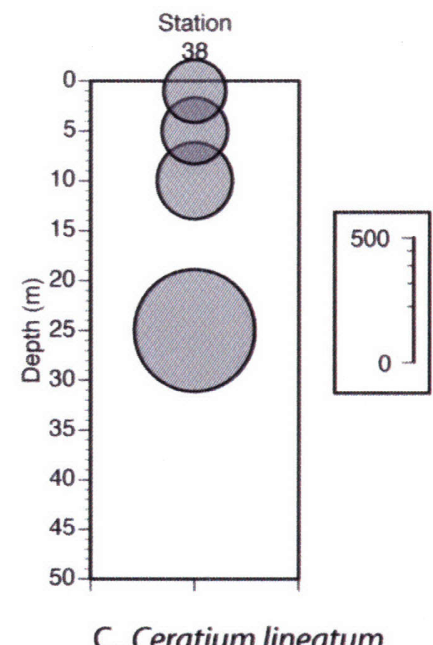

C. Ceratium lineatum 
Figure 11.

Concentrations of Protoperidinium spp. at Fastnet Rock station shown in cells $\mathrm{L}^{-1}$ : (A) Total Protoperidinium, (B) Protoperidinium crassipes, (C) Protoperidinium depressum, (D) Protoperidinium pyriforme, (E) Protoperidinium steinii. 


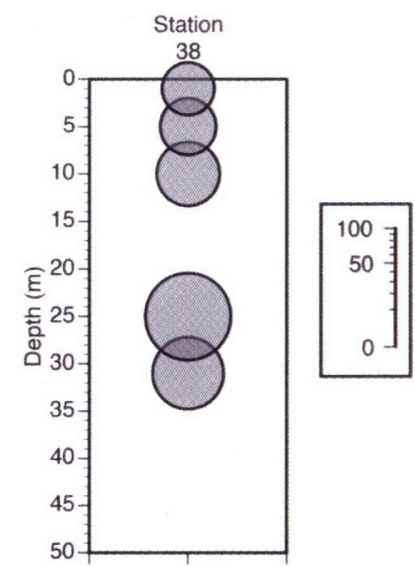

A. Total Protoperidinium

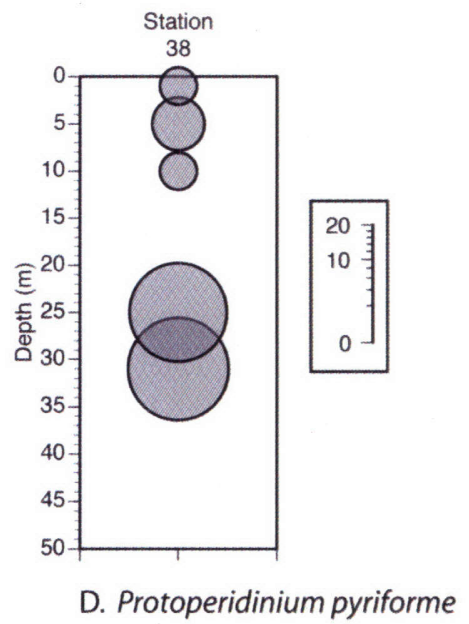

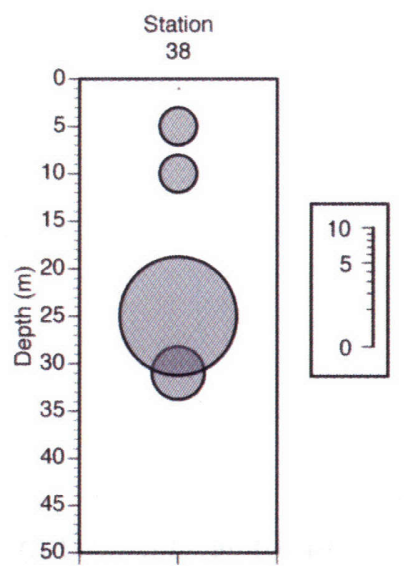

B. Protoperidinium crassipes

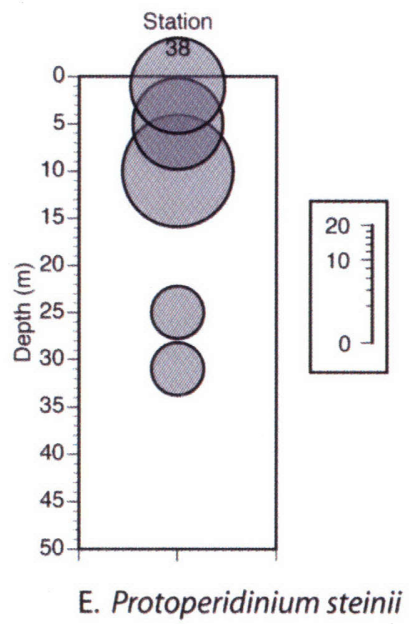

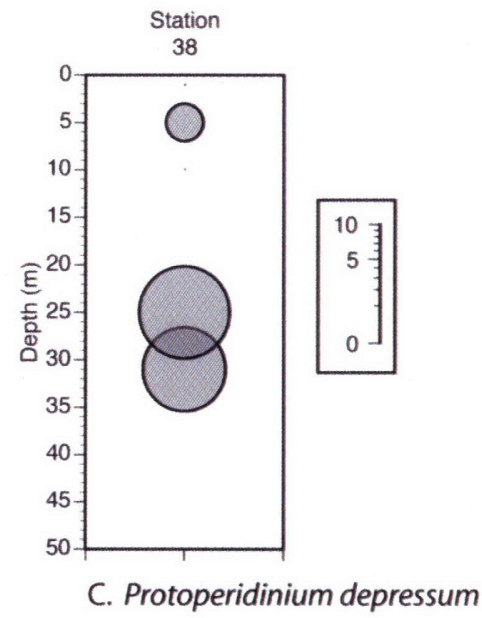


Figure 12.

Concentrations of other heterotrophic dinoflagellates and metazoa at Fastnet Rock station shown in individuals $\mathrm{L}^{-1}$ : (A) Noctiluca scintillans, (B) Oblea rotunda, (C) Copepods, (D) Copepod nauplii. 


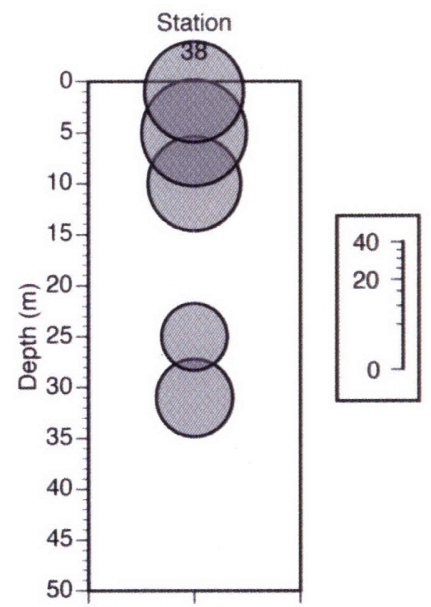

A. Noctiluca scintillans

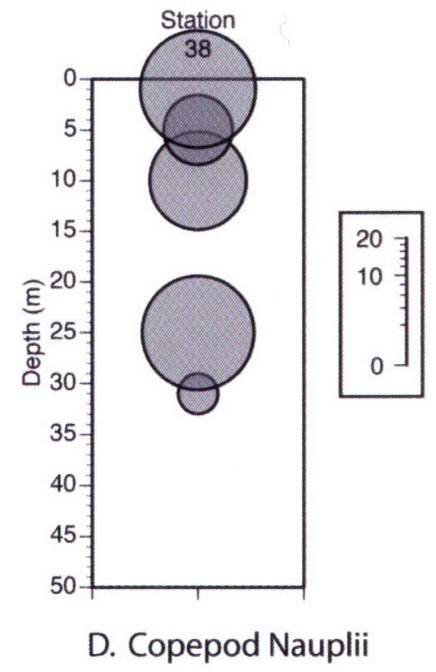

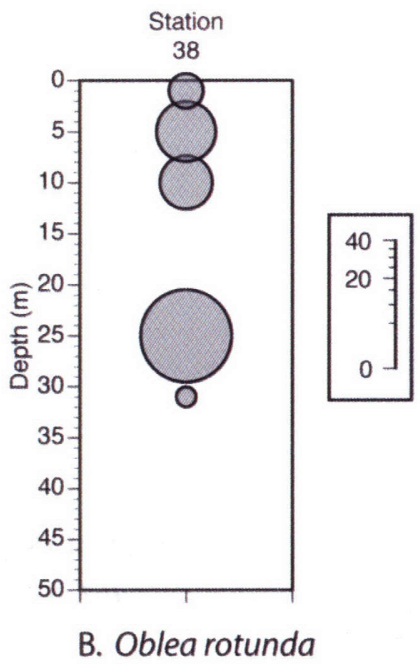

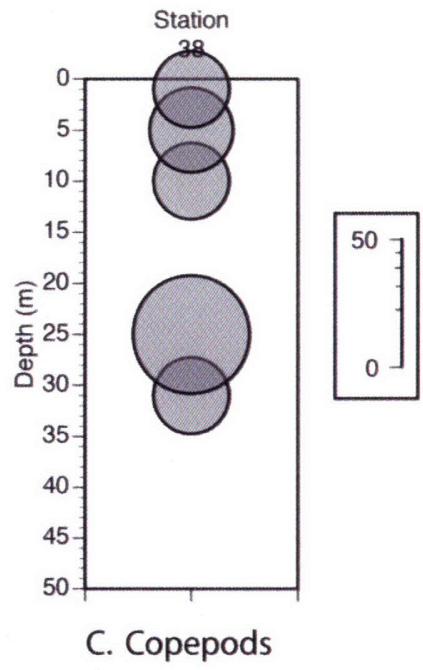


Figure 13.

Concentrations of diatoms along Bantry Bay section shown in cells $\mathrm{L}^{-1}$ : (A) Total diatoms, (B) Probescia alata, (C) Pseudo-nitzchia spp., (D) Rhizoselinia spp., (E) Leptocylindrus spp., (F) Nitzchia spp. 


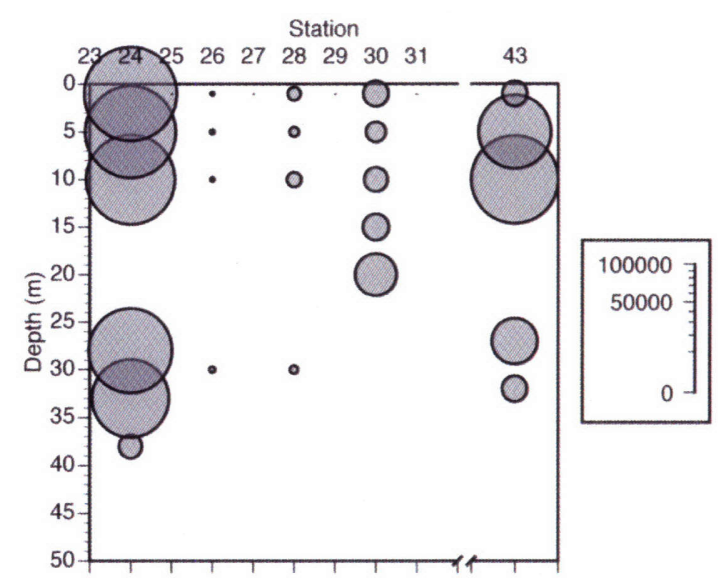

A. Total Diatoms

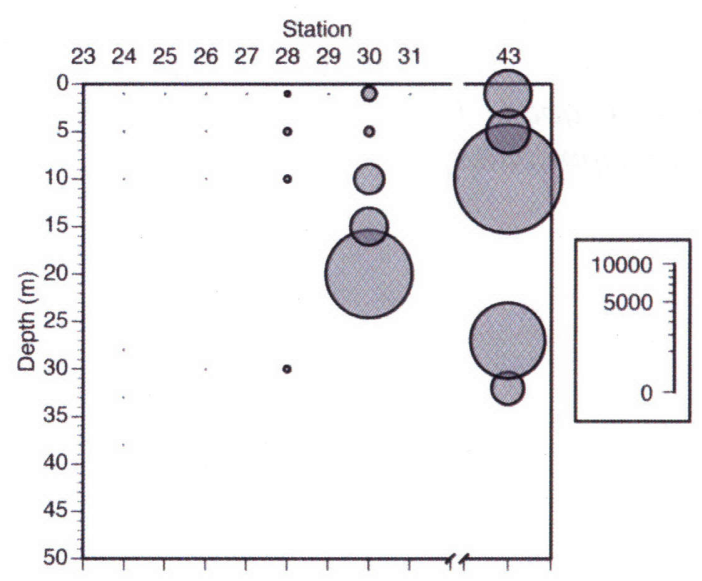

C. Pseudo-nitzchia spp.

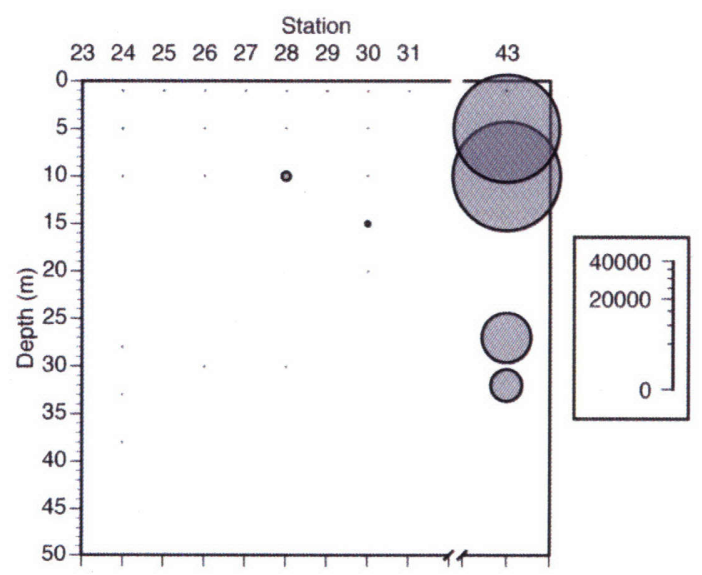

E. Leptocylindrus spp.

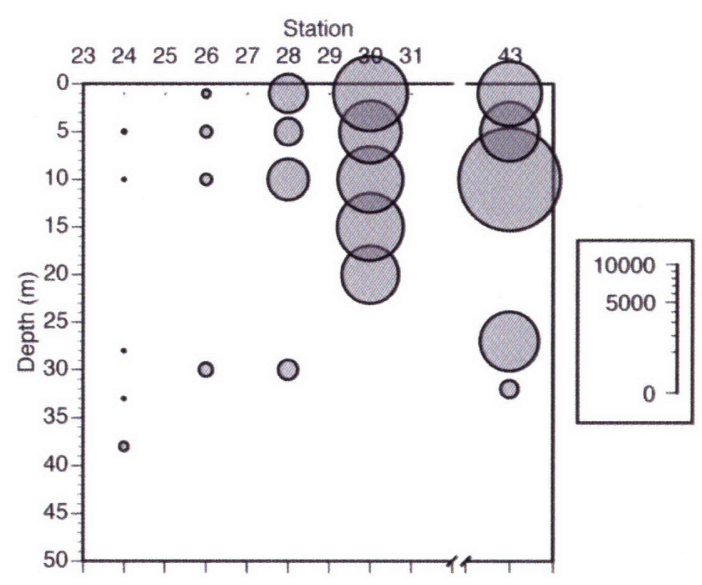

B. Probescia alata
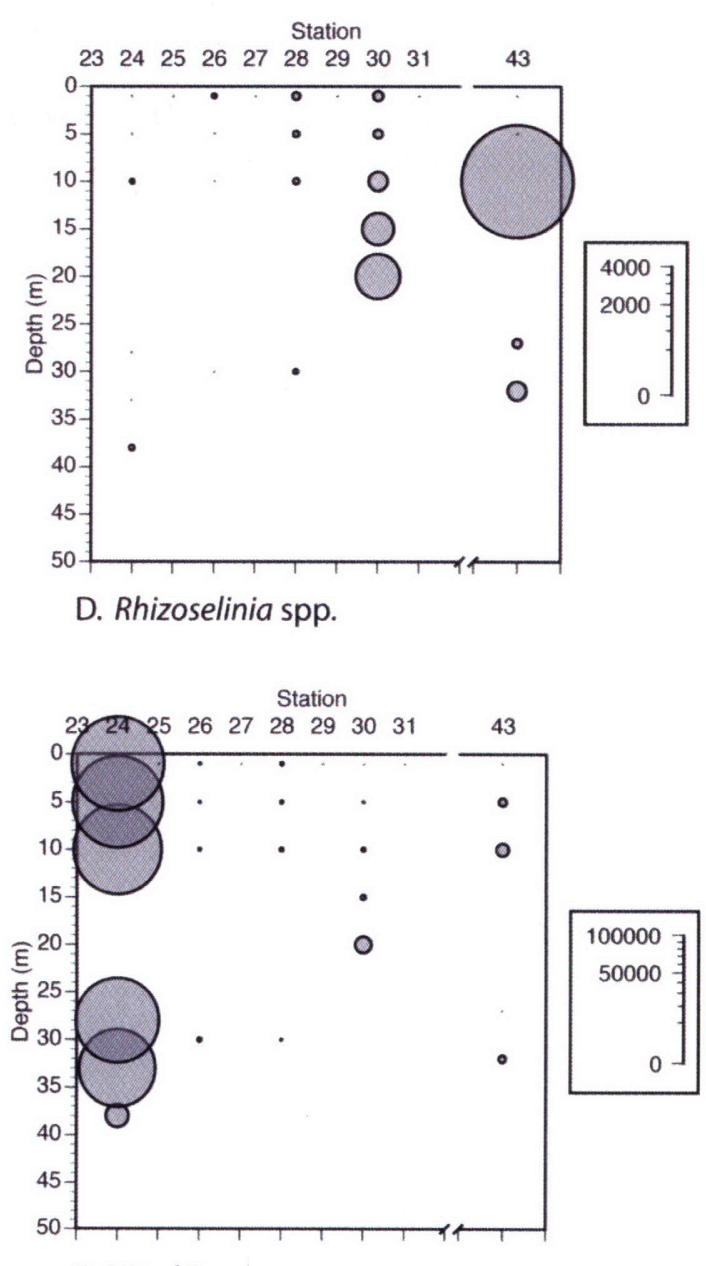

F. Nitzchia spp. 
Figure 14.

Concentrations of phototrophic dinoflagellates along Bantry Bay section shown in cells $\mathrm{L}^{-1}$ : (A) Total phototrophic dinoflagellates, (B) Ceratium setaceum, (C) Ceratium fusus, (D) Total Prorocentrum spp., (E) Ceratium lineatum, (F) Ceratium tripos, (G) Dinophysis acuminata, (H) Dinophysis acuta, (I) Scrippsiella spp. 
Station

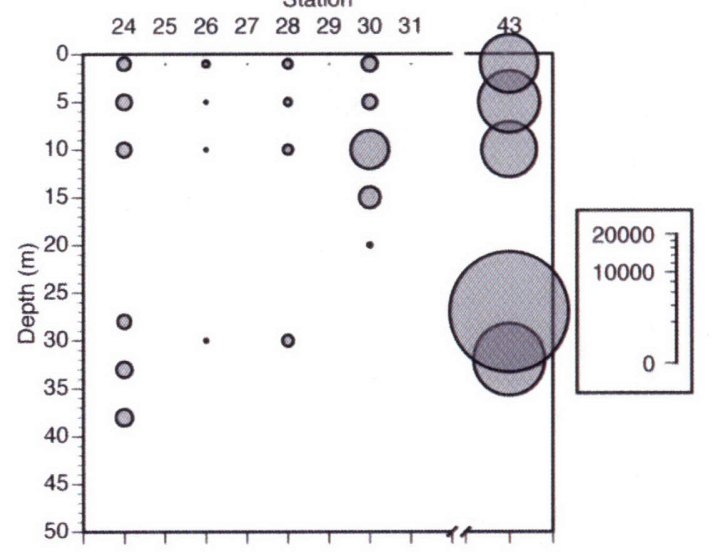

A. Total Dinoflagellates
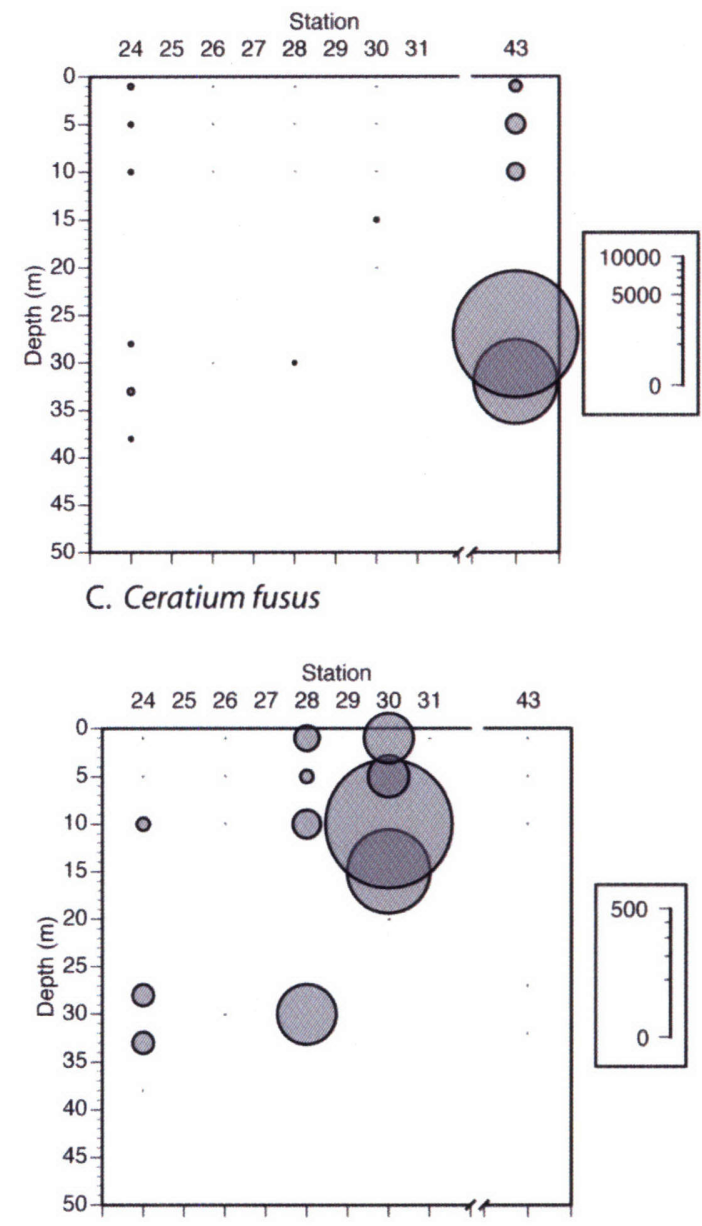

E. Ceratium lineatum

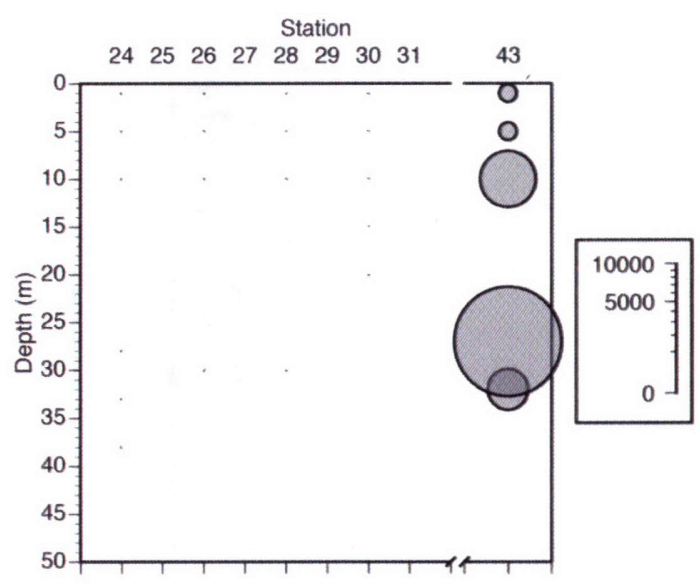

B. Ceratium setaceum
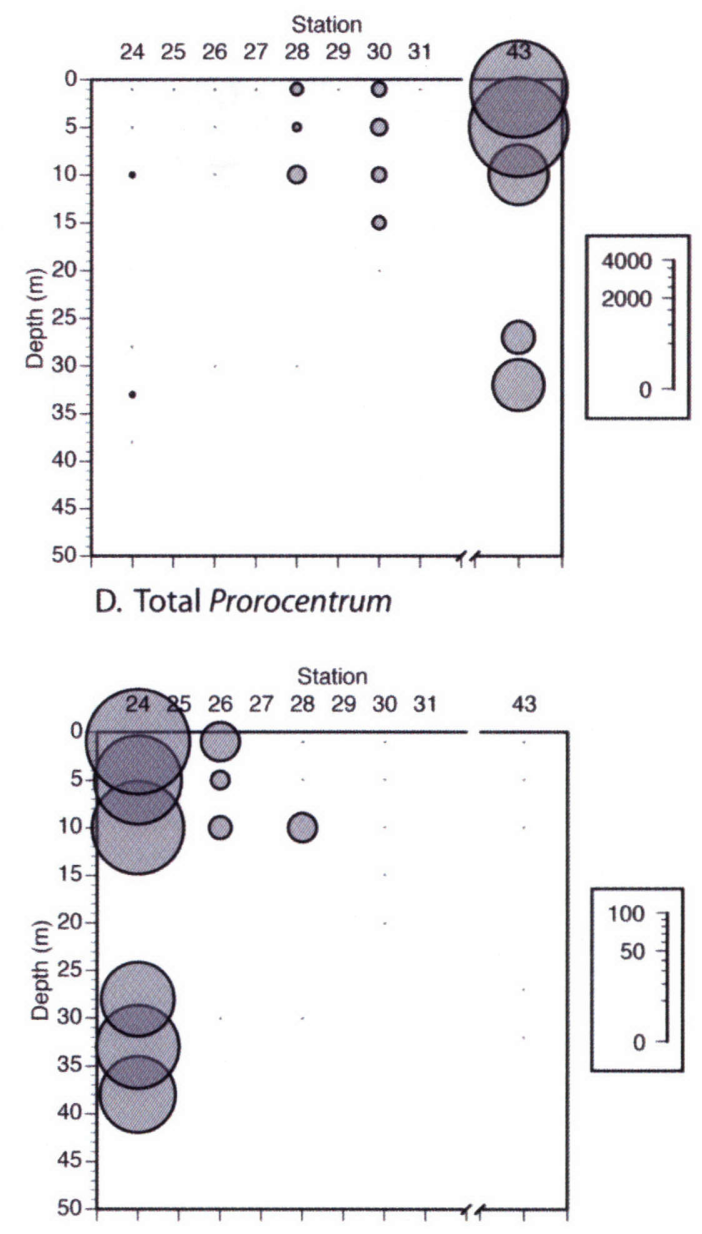

F. Ceratium tripos 
Station

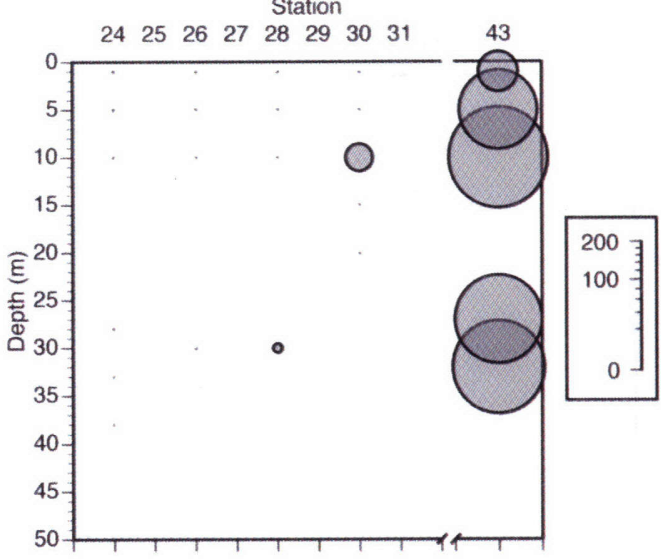

G. Dinophysis acuminata

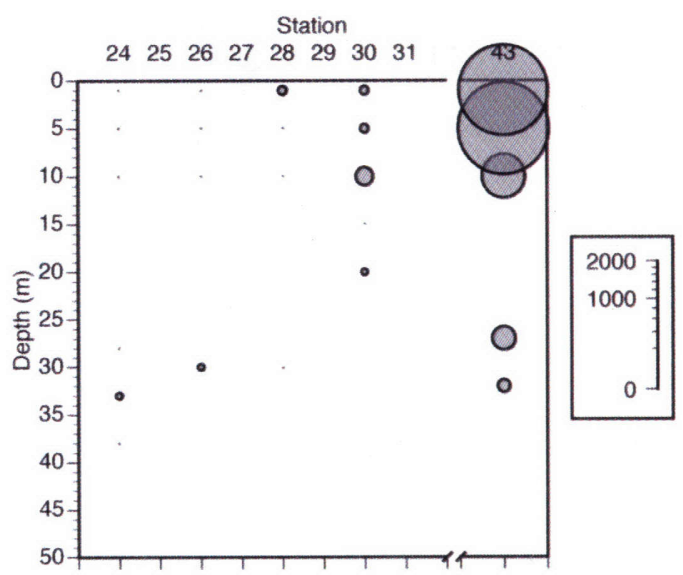

I. Scrippsiella spp.

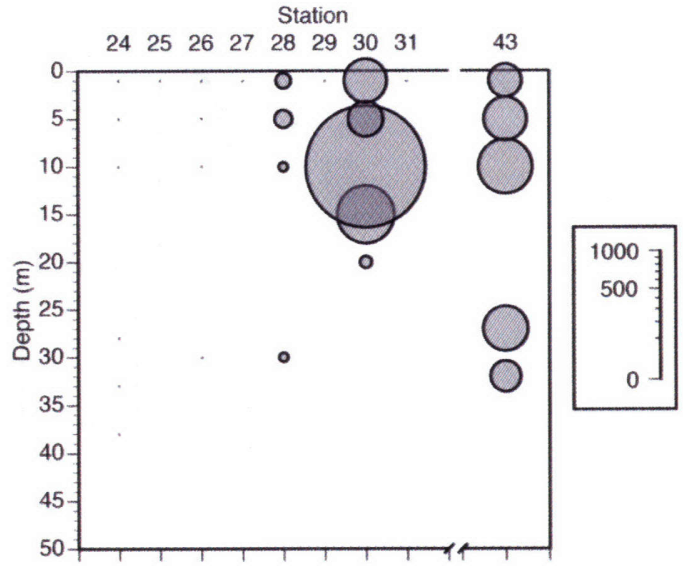

H. Dinophysis acuta 
dominated the community, reaching a maximum concentration of ca. 53,200 cells $\mathrm{L}^{-1}$ (Fig. 13F).

The dinoflagellate community along the Bantry Bay section was more diverse than on the Crease section or at the Fastnet Rock station. Concentrations of total phototrophic dinoflagellates were highest in the mouth of Bantry Bay with a peak concentration of more than 17,000 cells $\mathrm{L}^{-1}$ at a depth of $27 \mathrm{~m}$ (Fig. 14A), and was determined largely by the most abundant species, C. setaceum (Fig. 14B), C. fusus (Fig. 14C), and Prorocentrum spp. (Fig. 14D).

As expected, different dinoflagellate species, even those of the same genus, had varying distributions along the transect. Within the most abundant genus, Ceratium, C. fusus and C. setaceum had similar distributions-low to non-detectable at all stations except in the mouth of Bantry Bay, with the highest concentrations at $27 \mathrm{~m}$ (Figs. 14B-C). Ceratium lineatum and $C$. tripos had different distributions, with the former not detectable in the mouth of Bantry Bay, and most abundant at $10 \mathrm{~m}$ along the middle of the section, while the latter species was not seen in the nearshore stations, and was distributed through the water column at the outermost station (Figs. 14E-F). Seven different species of Dinophysis were present along the Bantry Bay section, with D. acuminata and D. acuta being most abundant. Dinophysis acuminata was found primarily in the mouth of Bantry Bay, distributed through the water column at concentrations near 100 cells L $\mathrm{L}^{-1}$ (Fig. 14G). Dinophysis acuta was detected from the mouth of Bantry Bay to the center of the section,

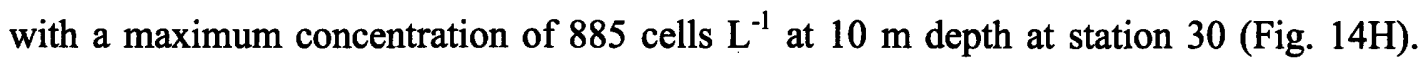
Prorocentrum spp. was comprised mostly of $P$. micans, with a low level of $P$. gracile found in only one sample along the Bantry Bay section. Prorocentrum micans was located predominantly in the surface waters at the mouth of Bantry Bay (ca. 2400 cells $\mathrm{L}^{-}$ 1 at $5 \mathrm{~m}$ ) (Fig. 14D). Relatively high concentrations of Scrippsiella were found only in the surface waters at the mouth of Bantry Bay (1000 cells $\mathrm{L}^{-1}$ at $\left.5 \mathrm{~m}\right)$ (Fig. 14I). 
Figure 15.

Concentrations of Protoperidinium spp. along Bantry Bay section shown in cells $\mathrm{L}^{-1}$ : (A) Total Protoperidinium, (B) Protoperidinium steinii, (C) Protoperidinium minutum, (D) Protoperidinium mite, (E) Protoperidinium pyriforme, (F) Protoperidinium pellucidum, (G) Protoperidinium brevipes, (H) Protoperidinium punctulatum, (I) Protoperidinium depressum, (J) Protoperidinium crassipes. 


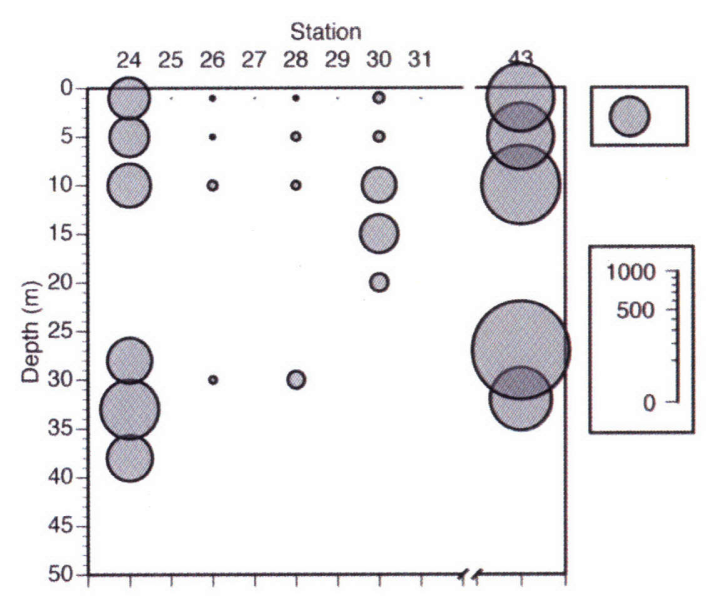

A. Total Protoperidinium

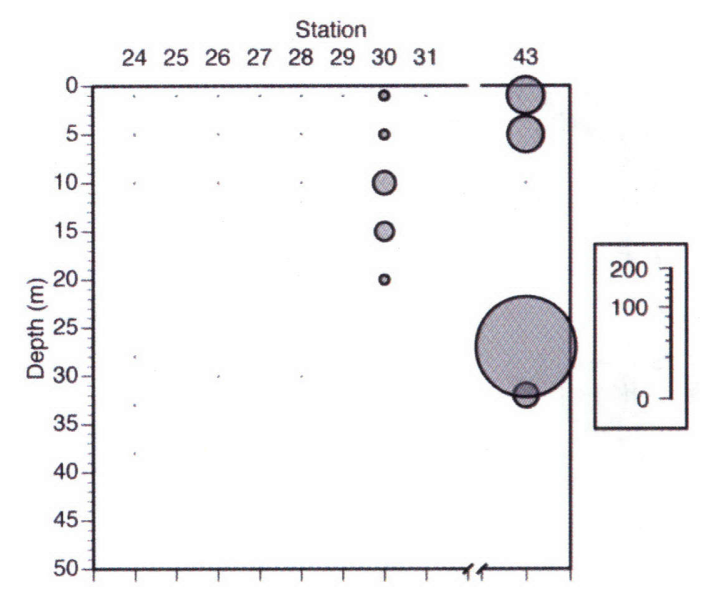

C. Protoperidinium minutum

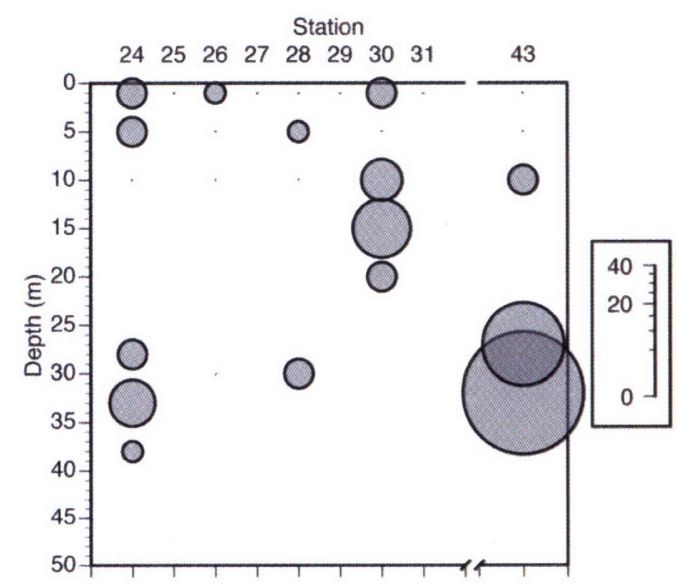

E. Protoperidinium pyriforme

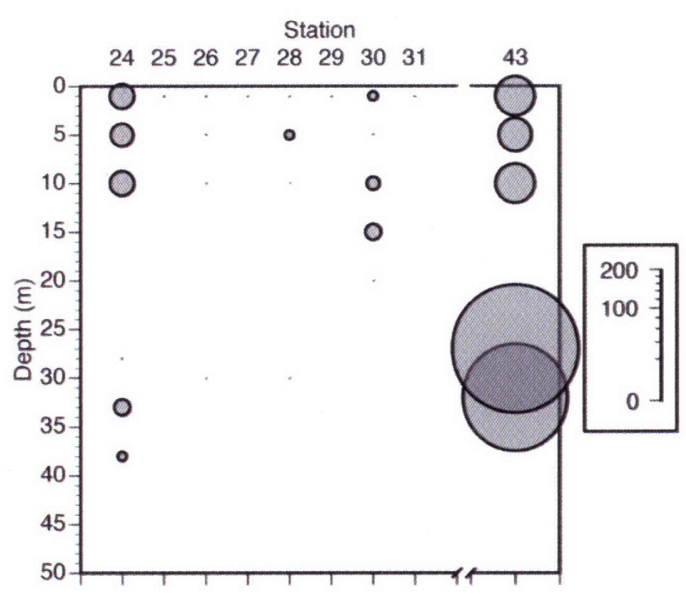

B. Protoperidinium steinii

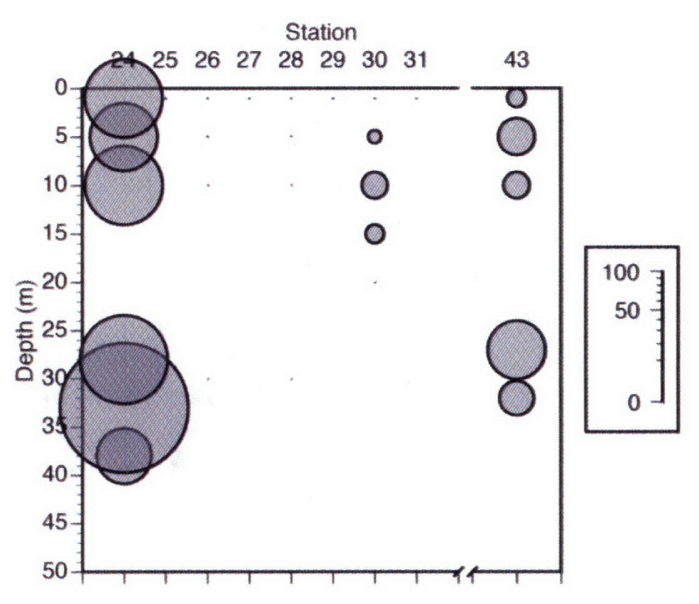

D. Protoperidinum mite

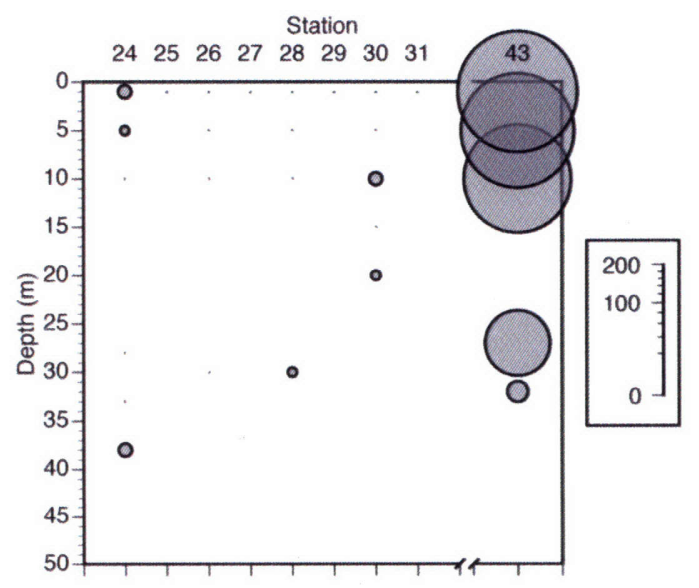

F. Protoperidinium pellucidum 


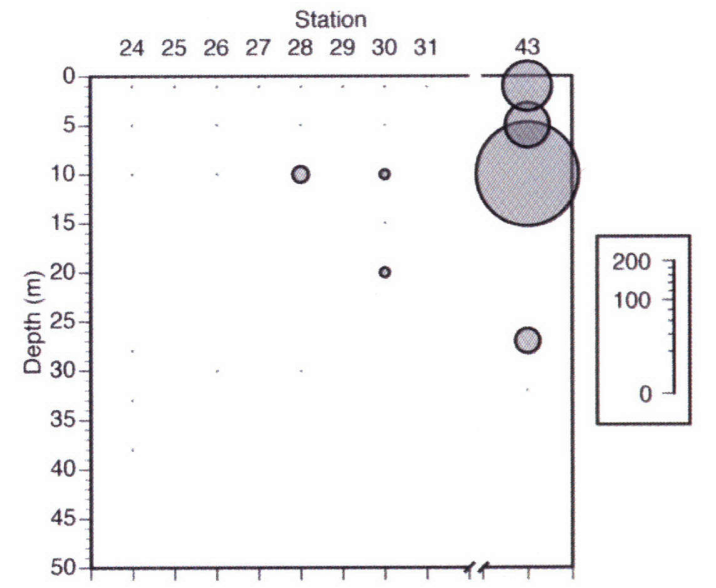

G. Protoperidinium brevipes

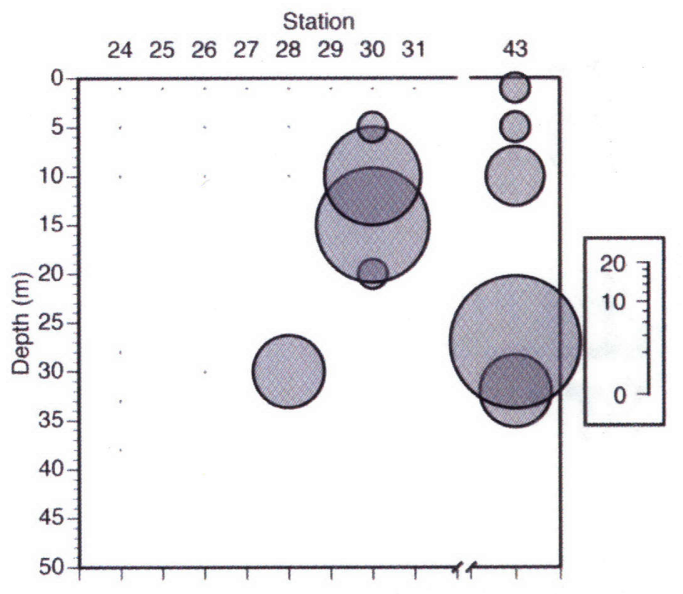

I. Protoperidinium depressum

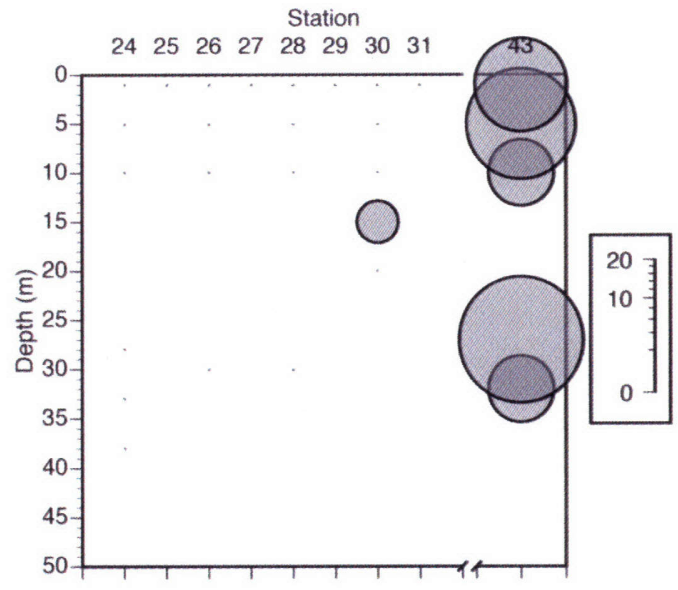

H. Protoperidinium punctulatum

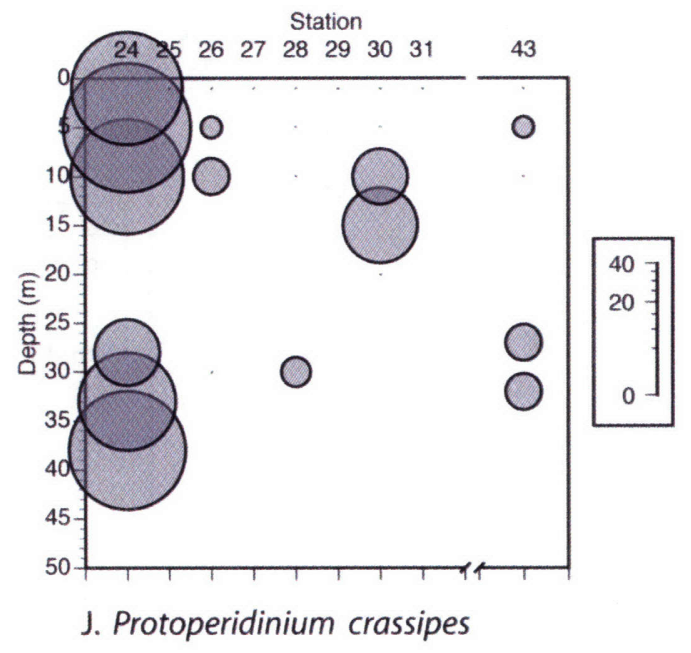


The concentration of total Protoperidinium spp. was highest in the mouth of Bantry Bay (maximum 561 cells $\mathrm{L}^{-1}$ at $27 \mathrm{~m}$ ), about half as high at the most offshore station (201 cells $\mathrm{L}^{-1}$ at $33 \mathrm{~m}$ ) and low in between (Fig. 15A). Protoperidinium spp. were distributed through the water column. A few species were found in low concentrations across the entire section, but most Protoperidinium spp. were located either primarily near the mouth of Bantry Bay, or primarily at the offshore-most station. At the mouth of the bay, $P$. steinii (maximum 190 cells $\mathrm{L}^{-1}$ at $32 \mathrm{~m}$ ) (Fig. 15B), P. minutum (maximum 119 cells $\mathrm{L}^{-1}$ at $27 \mathrm{~m}$ ) (Fig. 15C), P. mite (99 cells $\mathrm{L}^{-1}$ at $33 \mathrm{~m}$ ) (Fig. 15D) and P. pyriforme (maximum 35 cells $\mathrm{L}^{-1}$ at $32 \mathrm{~m}$ ) (Fig. 15E) were most abundant below the thermocline, while $P$. pellucidum (maximum 171 cells $\mathrm{L}^{-1}$ at $1 \mathrm{~m}$ ) (Fig. 15F) and $P$. brevipes (maximum 123 cells $\mathrm{L}^{-1}$ at $10 \mathrm{~m}$ ) (Fig. 15G) were found in the surface waters. $P$. punctulatum (Fig. 15H) and P. depressum (Fig. 15I) were found at the mouth of Bantry Bay through the whole water column, but in concentrations below 20 cells $\mathrm{L}^{-1}$. Protoperidinium crassipes (Fig. 15J) was distributed sparsely across the section and had its highest abundance of any station on the survey at the offshore-most station where it was found through the water column with a maximum concentration of 38 cells $\mathrm{L}^{-1}$ at 5 m.

Other thecate, heterotrophic dinoflagellates did not have a significant presence along the Bantry Bay transect, except for Diplopsalis lenticula and Preperidinium lenticulatum which were found at the station near the mouth of the bay at concentrations less than 35 cells $\mathrm{L}^{-1}$ and 20 cells $\mathrm{L}^{-1}$, respectively (data not shown). Concentrations of $N$. scintillans decreased moving from nearshore to offshore (Fig. 16A). Copepods and copepod nauplii were spread across the section and throughout the water column, in concentrations up to 80 copepods $\mathrm{L}^{-1}$ (Figs. 16B-C).

\section{Co-variation between Protoperidinium and phytoplankton}

To investigate possible specific predator-prey relationships between Protoperidinium species and individual species or groups of phytoplankton, regression analyses were 
Figure 16.

Concentrations of other heterotrophic dinoflagellates and metazoa along Bantry Bay section shown in individuals $\mathrm{L}^{-1}$ : (A) Noctiluca scintillans, (B) Copepods, (C) Copepod nauplii. 

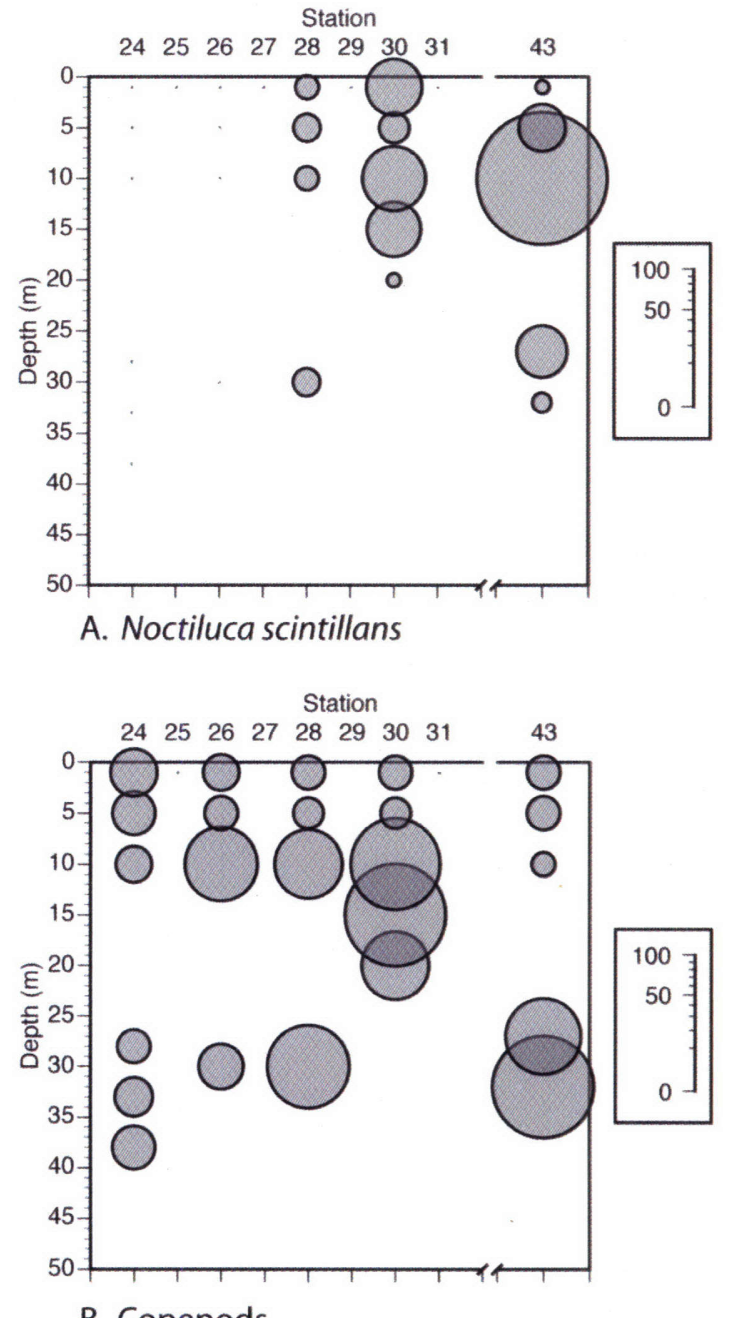

B. Copepods

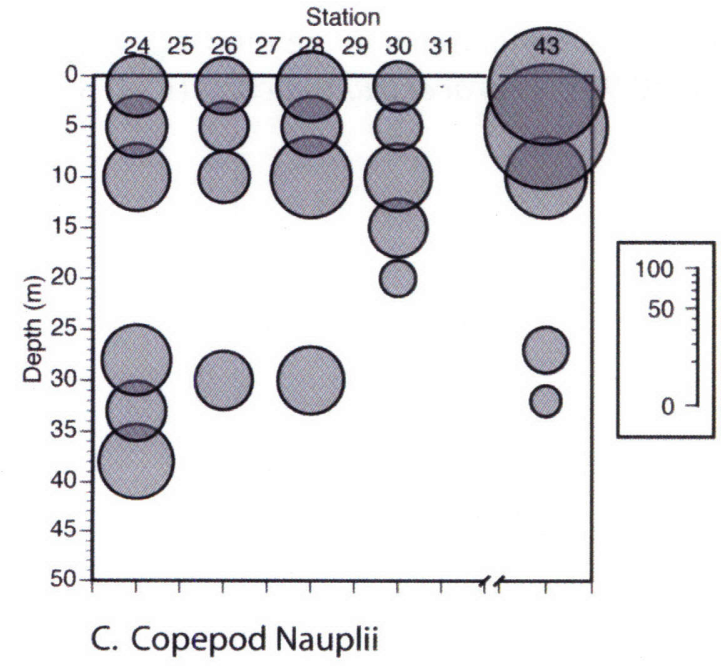


Figure 17.

Relationship between concentrations of Protoperidinium minutum and total diatoms $\left(\mathrm{r}^{2}=0.11\right)$ and total phototrophic dinoflagellates $\left(\mathrm{r}^{2}=0.89\right)$.

Figure 18.

Relationship between concentrations of Protoperidinium minutum and the dinoflagellates Ceratium fusus $\left(r^{2}=0.01\right)$, Ceratium setaceum $\left(r^{2}=0.90\right)$, Prorocentrum micans $\left(r^{2}=0.81\right)$ and the diatoms Chaetocerous spp. $\left(r^{2}=0.96\right)$. 

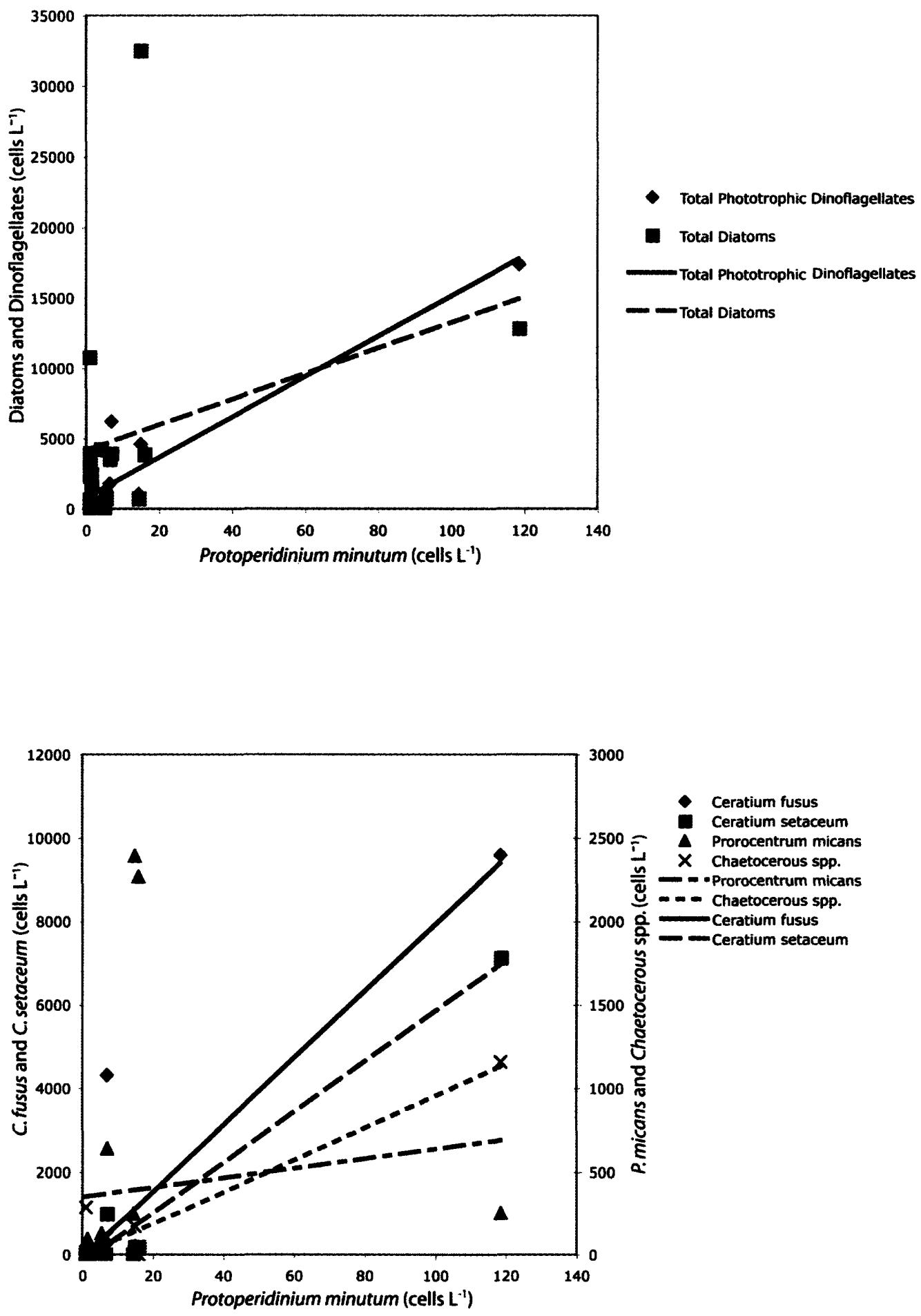
Figure 19.

Relationship between concentrations of Protoperidinium pellucidum and total diatoms $\left(r^{2}=0.14\right)$ and total phototrophic dinoflagellates $\left(r^{2}=0.10\right)$.

Figure 20.

Relationship between concentrations of Protoperidinium pellucidum and the dinoflagellates Prorocentrum micans $\left(\mathrm{r}^{2}=0.85\right)$, Scrippsiella spp. $\left(\mathrm{r}^{2}=0.82\right)$, and Gonyaulax spp. $\left(\mathrm{r}^{2}=0.84\right)$. 

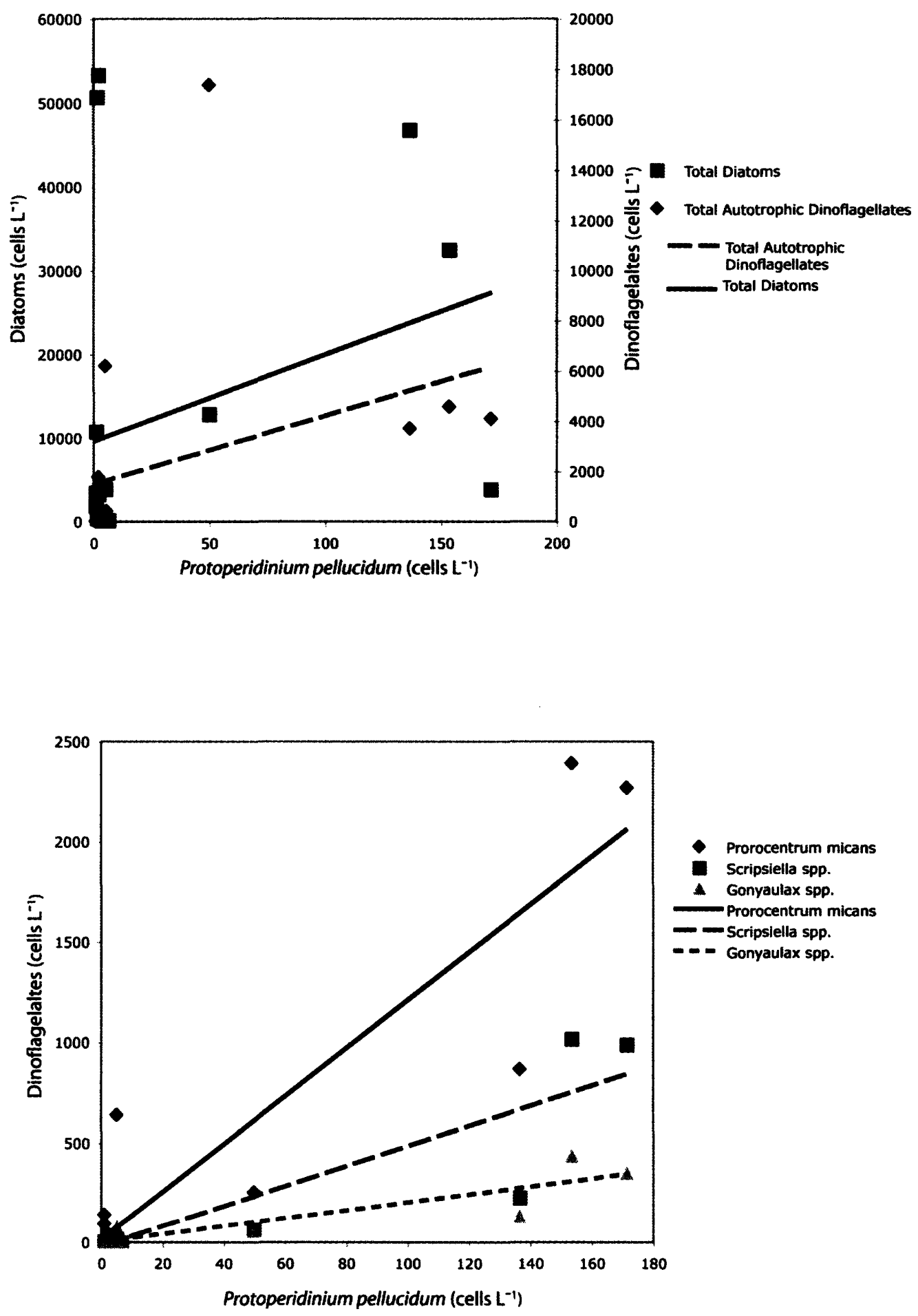
Figure 21.

Relationship between concentrations of Protoperidinium pyriforme and total diatoms $\left(r^{2}=0.01\right)$ and total phototrophic dinoflagellates $\left(r^{2}=0.26\right)$.

Figure 22.

Relationship between concentrations of Protoperidinium pyriforme and the dinoflagellates Ceratium fusus $\left(\mathrm{r}^{2}=0.13\right)$, Ceratium setaceum $\left(\mathrm{r}^{2}=0.16\right)$, and Prorocentrum micans $\left(\mathrm{r}^{2}=0.34\right)$. 

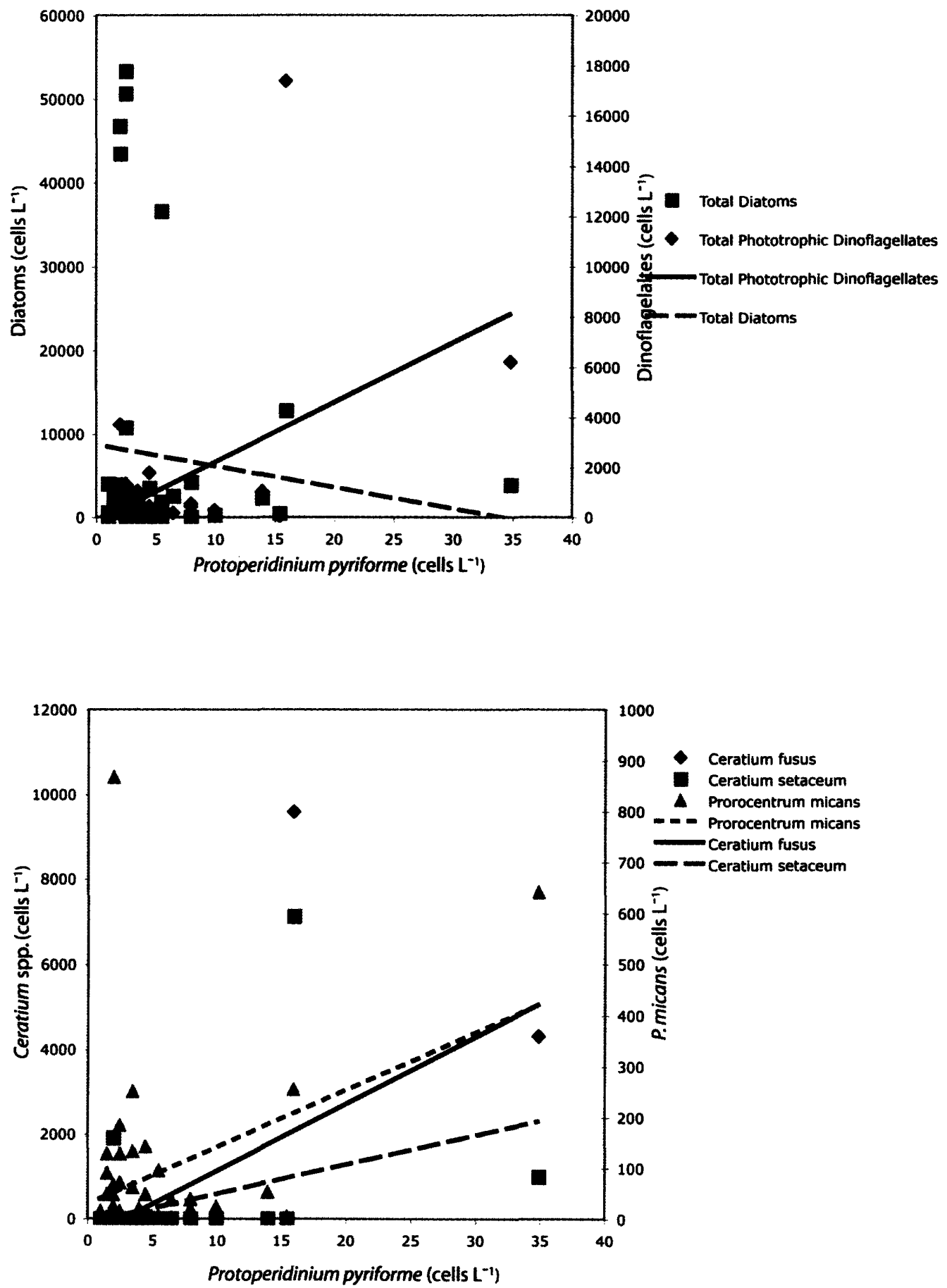
Figure 23.

Relationship between concentrations of Protoperidinium steinii and total diatoms $\left(r^{2}=0.83\right)$ and total phototrophic dinoflagellates $\left(r^{2}=0.0\right)$.

Figure 24.

Relationship between concentrations of Protoperidinium steinii and the dinoflagellates Ceratium fusus $\left(\mathrm{r}^{2}=0.75\right)$, Ceratium setaceum $\left(\mathrm{r}^{2}=0.71\right)$, and the diatoms Chaetocerous spp. $\left(r^{2}=0.95\right)$. 

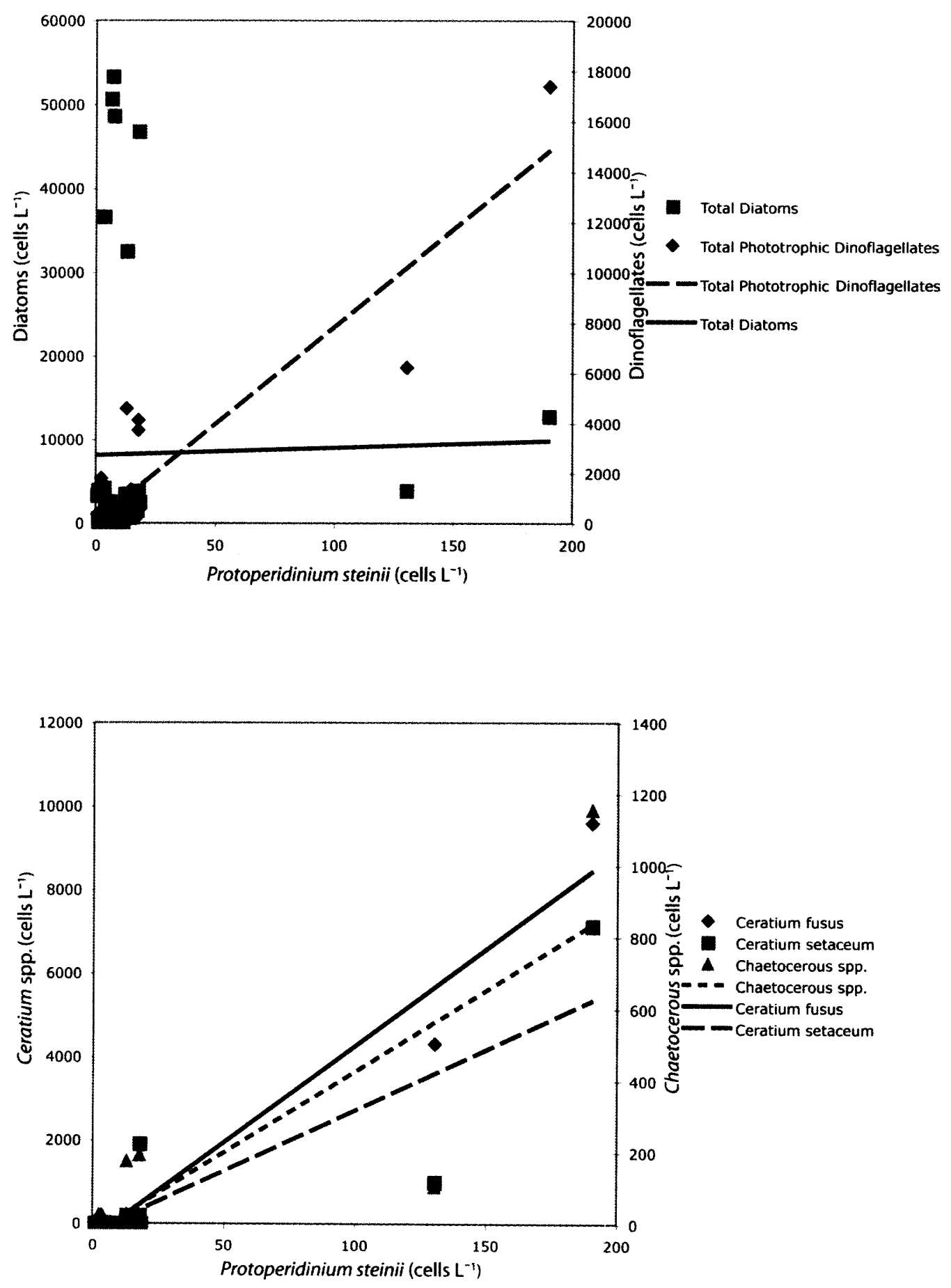
conducted on concentrations of individual Protoperidinium spp. and individual or groups of diatom or dinoflagellate species. Many species pairs had no detectable correlation or were negatively correlated. Those pairs of species with some degree of positive covariation are shown and discussed.

Protoperidinium minutum concentration was positively correlated with total phototrophic dinoflagellate concentration $\left(\mathrm{r}^{2}=0.89\right)$ but not with total diatom concentration $\left(\mathrm{r}^{2}=0.11\right)$ (Fig. 17). In particular, $P$. minutum was positively correlated with $C$. fusus $\left(\mathrm{r}^{2}=0.81\right)$ and C. setaceum $\left(\mathrm{r}^{2}=0.96\right)$, but not with $P$. micans. The only diatom with which $P$. minutum cell concentrations overlapped significantly was Chaetocerous spp. $\left(r^{2}=0.90\right)$ (Fig. 18).

The concentration of $P$. pellucidum was positively correlated with both total phototrophic dinoflagellate concentration and total diatom concentration, although the correlations were not statistically significant (Fig. 19). P. pellucidum was particularly well correlated with small dinoflagellates, including Scrippsiella spp. $\left(\mathrm{r}^{2}=0.82\right)$, Gonyaulax spp. $\left(\mathrm{r}^{2}=0.84\right)$, and P. micans $\left(\mathrm{r}^{2}=0.85\right)$ (Fig. 20).

Protoperidinium pyriforme cell concentration was positively, although not statistically significantly, correlated with concentration of total dinoflagellates, but negatively related to the concentration of total diatoms (Fig. 21). The species had positive, though not statistically significant, relationships with C. fusus, C. setaceum, and P. micans (Fig. 22). $P$. steinii co-occurred with a variety of phototrophs, primarily with dinoflagellates (Fig. 23), including $C$. fusus $\left(\mathrm{r}^{2}=0.95\right)$ and $C$. setaceum $\left(\mathrm{r}^{2}=0.77\right)$, but also with some diatoms, most significantly with Chaetocerous spp. $\left(r^{2}=0.71\right)$ (Fig. 24).

Although $P$. crassipes was found with many other dinoflagellates, the cell concentrations of $P$. crassipes did not correlate well with any of these, save a slight positive correlation with cell concentrations of $C$. macroceros $\left(\mathrm{r}^{2}=0.78\right)$. Concentrations of $P$. depressum 
were low throughout the study area, and did not correlate well with any individual phototrophic species or groups of species (data not shown).

\section{DISCUSSION}

This study describes the distributions of individual Protoperidinium species and cooccurring phototrophic dinoflagellates and diatoms and the relationships of those species to the hydrography off the southwestern coast of Ireland during the summer of 2003 . Our findings illustrate the patchy nature of plankton populations in the marine environment, and the differences in the ecology of different species, even those within the same genus.

Many informative studies of phytoplankton distribution and the hydrography along the southwest coast of Ireland have been conducted in the past (e.g., Raine et al. 1990; Raine et al. 1993; McMahon et al. 1995; McMahon et al. 1998; Raine and McMahon 1998; Raine et al. 2001). Previous published research of plankton distributions in this region has frequently focused on the distribution of a single species, often a toxic species with importance to human health and the aquaculture industry. Other studies have lumped similar species into broad categories, or have been non-quantitative, reporting the presence or absence of individual species, but not the relative importance of a given species within the plankton community. Little prior information was available about the distributions of Protoperidinium spp. in the area. The current study begins to define the ecologies of individual Protoperidinium species, and the potential microzooplankton

predator-phototroph prey relationships between species, in the context of the hydrography of the region.

\section{Methodology}

The methods employed during both sample collection and cell counting allowed detection and quantification of relatively rare and difficult to identify species. By concentrating the $>20 \mu \mathrm{m}$ plankton from $4 \mathrm{~L}$ of water before preservation, and then counting the equivalent of 1 to $2 \mathrm{~L}$ of whole water, I was able to detect species that might 
have been missed in smaller collection volumes. Protoperidinium species are often in low relative abundance in the plankton, and many of the species found had concentrations that would have been below detection in samples of smaller volumes.

Adding Calcofluor White to the samples prior to counting stained the thecal plates of dinoflagellates, allowing accurate identification of armored species. This was particularly important for Protoperidinium spp. More than 200 species of Protoperidinium have been described (Balech 1974), and thecal plate morphology is the primary means of distinguishing these species from one another. Many Protoperidinium species of similar size and shape are easily mis-identified without close examination of thecal plate morphology.

\section{Hydrography and plankton community}

Along both transects, the highest plankton concentrations often occurred at the thermocline, a phenomenon seen previously in this region (Raine et al. 1990; Raine et al. 1993; Raine and McMahon 1998; Cusack et al. 2006). Elevated densities of plankton are often seen at physical discontinuities like fronts. Temperature dictated the density structure along the southwest coast of Ireland during the time of the study, so the thermocline corresponds with the pycnocline, and may be a region of physical accumulation. Alternatively, the cells within the thermocline may be striking a balance between access to light near the surface and nutrients available in deeper waters, as the stratified surface waters become nutrient-depleted over the summer.

Chlorophyll fluorescence was not a good predictor of the distribution of a given species over the large, heterogeneous area of the survey. Relative fluorescence is generally considered a reliable indicator of production, but does not discriminate between different sources of primary productivity, such as picoplankton versus large diatoms. In the mouth of Bantry Bay, at stations 30 and 43, for example, a maximum in fluorescence existed at a depth of $15-20 \mathrm{~m}$. No corresponding maximum in total diatoms or total dinoflagellates 
is seen at this depth compared to other areas with lower fluorescence along the transect. The deep fluorescence maximum here was likely caused by humic runoff from land or by picoplankton too small to be detected by our sampling methods. On the other hand, a peak in total diatom cell concentration matched the fluorescence maximum at station 24 to the west of the Irish Shelf Front. Such differences in the primary producers at the base of the food chain would lead to very different plankton community structures, like the difference between the offshore and onshore Protoperidinium species seen in this study. Cyanobacteria and picoeukaryotes, while important for the ecology of the system, may be ignored for the purposes of the trophic ecology of Protoperidinium, since Protoperidinium have been shown to have positive growth rates only on planktonic prey of their own size (Jacobson and Anderson 1986; Jeong and Latz 1994; Buskey 1997; Naustvoll 2000; Menden-Deuer et al. 2005).

The Irish Shelf Front is a well-characterized feature off the southern and southwestern coasts of Ireland, and during this survey was located in the same general region in the Celtic Sea and west of Bantry Bay as in previous studies (Huang et al. 1991; McMahon et al. 1995; Raine and McMahon 1998). On both the Crease and Bantry Bay transects, the plankton community differed across the front. On the Crease section, phytoplankton and heterotrophic dinoflagellates were more abundant and a more diverse plankton assemblage was found inshore of the Irish Shelf Front than offshore and to the south of the front. Along the Bantry Bay transect, plankton communities were different on different sides of the front. In general, diatoms were more abundant offshore, while dinoflagellates had their highest concentrations inshore. The distribution of individual species was more complicated, however, and individual diatom or dinoflagellate species deviated from the average.

One interesting difference between this study and previous studies in this region was the dominance of diatoms in the stratified waters offshore, while dinoflagellates dominated in the nearshore, better-mixed waters on the Crease section. One might have expected, and 
indeed, previous studies in this region have found, that diatoms fare better in turbulent or well-mixed waters, while dinoflagellates dominate in stratified waters (McMahon et al. 1995). In the case of this study, the strong fresh water influence in the surface waters near shore may have contributed to the higher relative abundance of dinoflagellates (Franks and Anderson 1992). Alternatively, it has been noted from time series and multiyear studies in the region that the seasonal succession of phytoplankton species sometimes progresses more quickly in the nearshore compared to offshore of the front. Sampling may have occurred during a period in time when the spring diatom bloom was still underway in the offshore waters, but had given way to the summer population of dinoflagellates in the nearshore waters.

Physically defined boundaries for community assemblages, like thermoclines and fronts, can become important for determining plankton populations inside the bays along the southwestern coast of Ireland. Raine and others have described the conditions necessary to transport plankton into bays on the southwestern coast of Ireland. As in previous studies, we found geostrophic flows to the west along the southern coast of Ireland, wrapping around and flowing north/northwest past the mouth of Bantry Bay. The normal mid summer flow in this region inshore of the front is clockwise around the coast, while offshore of the front the flow is toward the south (Raine and McMahon 1998). Thus, plankton populations that form nearshore and are concentrated along the thermocline in the Celtic Sea have the potential to be entrained and transported to the northwest along the coast, past the large southwestern bays. With southwesterly winds, these populations can be transported into the bays, and as the winds relax, deposited there (Raine et al. 1993; Edwards et al. 1996; Raine and McMahon 1998). Through this physical accumulation and with appropriate growth conditions blooms can form very rapidly in the southwestern bays. Offshore monitoring of plankton abundances and distributions as in this study, when combined with observations of wind and weather conditions, could allow predictions of plankton blooms in southwestern bays and be used to determine the potential for impact to shellfish and finfish aquaculture in bays. 
At the time of sampling, the highest concentrations of $P$. crassipes occurred offshore of Bantry Bay, well away from sites of shellfish aquaculture. During this same time period, no AZA was detected in shellfish in southwestern Ireland. These results, unfortunately do not allow determination of whether $P$. crassipes is responsible for AZA toxicity in the region.

\section{Protoperidinium-phytoplankton relationships}

Few statistically significant correlations between individual Protoperidinium species and specific phototrophs were found, likely due in part to the high degree of variability in cell concentrations and relatively low concentrations of most Protoperidinium species in the study area. Some of the positive correlations supported previous laboratory studies on the preferred food types of particular Protoperidinium spp., partially validating our method of using the degree of co-occurrence across the study area as a measure of species-specificity in trophic relationships.

Protoperidinium steinii for example, co-occurred with a range of phototrophs, and lab studies have shown that $P$. steinii is able to successfully grow on a variety of prey species (Naustvoll 2000). Additionally, P. pellucidum has been shown to grow on small dinoflagellates as well as on diatoms (Hansen 1992; Buskey 1997), consistent with the correlation of $P$. pellucidum cell concentrations in this study with Scrippsiella spp., Gonyaulax spp., and P. micans. Similarly, P. pyriforme concentrations were not correlated with diatom concentrations, but co-varied with the dinoflagellates $C$. fusus, $C$. setaceum and $P$. micans, possibly indicating that this species feeds more-specifically on a limited selection of dinoflagellates. These results support those of the early study by Jacobson and Anderson (1986) in which P. pyriforme was the only of 14 Protoperidinium species that fed exclusively on dinoflagellates.

In this study, $P$. minutum co-varied with total dinoflagellates and in particular with $C$. fusus and $C$. setaceum. The only diatom with which $P$. minutum was correlated was 
Chaetocerous spp. Previously, P. minutum was shown to feed on solitary diatoms, although no information was provided about growth rates on different prey species (Jacobson and Anderson 1986). These results could indicate that $P$. minutum is a generalist feeder, as has been shown for some other Protoperidinium species, including P. steinii and P. pellucidum (Hansen 1992; Buskey 1997; Naustvoll 2000). Based on the co-occurrences of these species with particular phototrophs, predictions can be made and focused food-preference studies easily conducted in the laboratory for Protoperidinium spp. These observations may also be helpful in attempts to bring these Protoperidinium species into culture.

Correlations between specific predator-prey pairs of species like those seen in this study and in previous laboratory experiments suggest that these microzooplankton may play an important role in control of populations of particular phytoplankton species. In the waters off the southwestern coast of Ireland at the time of this study, Protoperidinium spp. were likely competing with other consumers of large phytoplankton, including copepods and other heterotrophic dinoflagellates, particularly Noctiluca scintillans. Growing evidence indicates that the impact of microzooplankton like Protoperidinium on phytoplankton populations, bloom structure, and cycling of organic matter can be important--even more significant than that of mesozooplankton--at particular times and locations (Smetacek 1981; Archer et al. 1996; Tiselius and Kuylenstierna 1996; Tillmann and Hesse 1998; Kjaeret et al. 2000; Fileman and Burkill 2001; Levinsen and Nielsen 2002; Verity et al. 2002). Few authors have attempted evaluations of grazing impact of individual or groups of Protoperidinium species in the field, however. In most previous work, grazing by Protoperidinium has not been separated from that of other microzooplankton species such as other thecate or athecate heterotrophic dinoflagellates or ciliates, which may have very different grazing rates and/or preferred food types.

Grazing rates have been measured in the laboratory for only a few thecate heterotrophic dinoflagellate species feeding on selected prey, and vary among species and differ 
greatly depending upon prey type, making it difficult to extrapolate laboratory grazing results to the field. These limited measurements are still useful, however, in that they can help estimate the potential trophic impact of Protoperidinium species in the field.

Protoperidinium pellucidum for example, has a maximum ingestion rate of 0.78 prey cells dinoflagellate $\mathrm{hr}^{-1}$ (Buskey, 1997) when feeding on the diatom Ditylum brightwellii. With a maximum concentration of 170 cells $\mathrm{L}^{-1}$ at the mouth of Bantry Bay, $P$. pellucidium could consume approximately $80 \%$ of the standing stock of total diatoms per day at the same station, assuming a constant grazing rate on all diatom species. At the other end of the grazing spectrum, $P$. crassipes has one of the lowest reported grazing rates, consuming 0.1 prey cells dinoflagellate $\mathrm{hr}^{-1}$ when feeding on the dinoflagellate Lingulodinium polyedrum (Jeong and Latz 1994). Protoperidinium crassipes was found in low concentration in the study area, with a maximum concentration of 38 cells $\mathrm{L}^{-1}$ offshore on the Bantry Bay section. Phototrophic dinoflagellates are the preferred prey of $P$. crassipes (Jeong and Latz 1994), so if this low grazing rate is constant in the field, this heterotroph could consume $30 \%$ of the standing stock of phototrophic dinoflagellates per day at the same station. As these estimates of grazing are for single Protoperidinium species, the trophic impact of thecate heterotrophic dinoflagellates in the waters of southwestern Ireland may be even higher. Phytoplankton community composition and environmental conditions such as temperature may influence grazing rates of Protoperidinium species in the field, however. Quantification of the trophic role of Protoperidinium in different environments is needed, and may help determine if Protoperidinium are important in the field as vectors of phycotoxins.

Many of the correlations between concentrations of particular Protoperidinium species and concentrations of groups of species or individual species of autotrophic dinoflagellates or diatoms were not statistically significant, even in some cases where we would have expected positive correlations based on previous laboratory studies of preferred food types. For example, concentrations of $P$. crassipes did not correlate well 
with any diatoms or dinoflagellates. We would expect from previous work that $P$. crassipes would survive well when feeding on dinoflagellates like Lingulodinium polyedrum, but not successfully feed and survive on diatoms (Jeong and Latz 1994, Gribble Unpubl. data).

There are a number of possible explanations for a lack of significant correlations between Protoperidinium and putative specific prey species in the field. First, there may a lag time between the peak concentrations of prey and predator, as might be expected in a zooplankton-phytoplankton predator-prey relationship. This would not have been detected in our single time point study. Sampling over time would help to clarify possible species-specific relationships. Kjaeret et al. (2000) found the peaks in some Protoperidinium sp. concentrations occurred at the same time as peaks in likely preferred prey concentrations during their time-series sampling study, however, indicating that sampling at a single time point, as we have done in the present study, can be a valid way to determine possible specific predator-prey relationships.

Second, Protoperidinium species in the field may have preferred food types, as has been demonstrated for some species in the lab, but may supplement their diets with additional, non-optimal species, leading to less than perfect correlations. Some Protoperidinium species may prey on organisms normally thought of as belonging to higher trophic levels. Protoperidinium cf. divergens has been shown to consume copepod eggs and nauplii, for example (Jeong 1996). In field samples from Ireland maintained in the laboratory, Protoperidinium divergens has been observed to consume a large copepod (Appendix 1, this thesis). This species may be acting as a predator or if the copepod was dead before consumption, as a detritivore. If the latter is the case, then Protoperidinium may reside lower in the water column than where we sampled, perhaps even at the sediment surface, to take advantage of organic particles settling from the surface waters. Such a distribution would lead to both underestimation of Protoperidinium abundance and to a 
disconnect between the concentrations of Protoperidinium species and expected preferred phytoplankton prey.

Finally, some Protoperidinium spp. have been shown to survive for extended periods of time, up to 71 days in the case of $P$. depressum, in conditions of starvation or extrememly low food availability (Jakobsen and Hansen 1997; Menden-Deuer et al. 2005). The ability to endure extended starvation is a useful strategy for a planktonic predator, particularly one that is a specific feeder on patchy and food resources. Thus, the presence of a Protoperidinium species in an area does not guarantee that conditions there were optimal for growth.

\section{CONCLUSIONS}

This study investigated the distribution and geographic correlations between Protoperidinium species and their potential phytoplankton prey species over a large area at a single time. At the time of sampling, the plankton assemblage was diverse, and individual species had distinctive distributions related to the hydrography of the region, particularly to the location of the Irish Shelf Front indicating possible niche differentiation.

While the sampling regime did not allow examination of species succession in the plankton community, we did find that Protoperidinium species in the field tend to be associated with the phytoplankton species that have been shown to be their preferred foods in the laboratory. Our results illustrate the need to investigate the ecologies of different Protoperidinium spp. separately if we are to better understand plankton trophic dynamics.

Phytoplankton and protistan species are frequently lumped into broad categories and treated as though they have similar ecologies, particularly in large field programs. The study of the distribution of Protoperidinium and other plankton species off the coast of 
Ireland illustrates the diversity in the distributions of species even within the same genus. The distribution of Protoperidinium may be controlled by availability of prey and by the same token, Protoperidinium may be important controls on distribution and seasonality of their preferred prey species.

\section{ACKNOWLEDGEMENTS}

Thank you to the captain and crew of the R/V Celtic Voyager. Thanks to Glenn Nolan and Kieran Lyons for assistance with figures of hydrography. Funding for this project came from the Comer Foundation, the Carroll Wilson Award from the MIT Entrepteneurship Society, and National Science Foundation grant OCE-0136861.

\section{REFERENCES}

ArCher, S. D., R. J. G. LeAKey, P. H. Burkill, and M. A. Sleigh. 1996. Microbial dynamics in coastal waters of East Antarctica: Herbivory by heterotrophic dinoflagellates. Marine Ecology Progress Series 139: 1-3.

BAlech, E. 1974. El genero Protoperidinium Bergh, 1881 (Peridinium Ehrenberg, 1831, Partim). Revista del Museo Argentino de Ciencias Naturales "Bernardino Rivadavia" e Instituto Nacional de Investigacion de las Ciencias Naturales 4: 179.

BUSKEY, E. J. 1997. Behavioral components of feeding selectivity of the heterotrophic dinoflagellate Protoperidinium pellucidum. Marine Ecology Progress Series 153: 77-89.

Cusack, C., J. Silke, G. McDermott, t. NokklegaArd, G. Nolan, M. Gilmartin, and R. RAINE. 2006. The Biological Oceanography of Harmful Algal Blooms (BOHAB) Programme: Special emphasis on the dinoflagellate genus Dinophysis, p. 55-63, 6th Irish Shellfish Safety Scientific Workshop. Marine Institute.

Edwards, A., K. J. Jones, J. M. Graham, C. R. Griffiths, N. MacDougall, J. W. PATCHING, J. M. RICHARD, and R. RAINE. 1996. Transient coastal upwelling and water circulation in Bantry Bay, a ria on the SW coast of Ireland. Estuarine, Coastal and Shelf Science 42: 213-230. 
FILEMAN, E. S., and P. BURKILl. 2001. The herbivorous impact of microzooplankton during two short-term Lagrangian experiments off the NW coast of Galacia in summer 1998. Progress in Oceanography 51: 361-383.

FRANKS, P. J. S., and D. M. ANDERSON. 1992. Alongshore transport of a toxic phytoplankton bloom in a buoyancy current: Alexandrium tamarense in the Gulf of Maine. Marine Biology 116: 153-164.

FRITZ, L., and R. E. TRIEMER. 1985. A rapid simple technique utilizing Calcofluor white M2R for the visualization of dinoflagellate thecal plates. Journal of Phycology 21: 662-664.

GAINES, G., and F. J. R. TAYLOR. 1984. Extracellular digestion in marine dinoflagellates. Journal of Plankton Research 6: 1057-1062.

HANSEN, P. J. 1992. Prey size selection, feeding rates and growth dynamics of heterotrophic dinoflagellates with special emphasis on Gyrodinium spirale. Marine Biology, Heidelberg 114: 327-334.

HASLE, G. R. 1978. Using the inverted microscope, p. 191-196. In A. Sournia [ed.], Phytoplankton Manual. Unesco.

Huang, W. G., A. P. Cracknell, R. A. Vaughan, and P. A. Davies. 1991. A satellite and field view of the Irish Shelf front. Continental Shelf Research 11: 543-562.

JACOBSON, D. M., and D. M. ANDERSON. 1986. Thecate heterotrophic dinoflagellates: Feeding behavior and mechanisms. Journal of Phycology 22: 249-258.

JAKOBSEN, H. H., and P. J. HANSEN. 1997. Prey size selection, grazing and growth response of the small heterotrophic dinoflagellate Gymnodinium sp. and the ciliate Balanion comatum - a comparative study. Marine Ecology Progress Series 158: 75-86.

James, K. J., C. Moroney, C. Roden, M. Satake, T. Yasumoto, M. Lehane, and A. FUREY. 2003. Ubiquitous 'benign' alga emerges as the cause of shellfish contamination responsible for the human toxic syndrome, azaspiracid poisoning. Toxicon 41: 145-151.

JEONG, H. J. 1996. The predation impact by the heterotrophic dinoflagellate Protoperidinium cf. divergens on copepod eggs in the presence of co-occurring 
phytoplankton prey. Journal of the Oceanological Society of Korea. Seoul 31: 144-149.

JEONG, H. J., and M. I. LATZ. 1994. Growth and grazing rates of the heterotrophic dinoflagellates Protoperidinium spp. on red tide dinoflagellates. Marine Ecology Progress Series 106: 173-185.

KJaeret, A. H., L. J. NAustvoll, and E. PAasche. 2000. Ecology of the heterotrophic dinoflagellate genus Protoperidinium in the inner Oslofjord (Norway). Sarsia 85: 5-6.

LEVINSEN, H., and T. G. NIELSEN. 2002. The trophic role of marine pelagic ciliates and heterotrophic dinoflagellates in Arctic and temperate coastal ecosystems: A crosslatitude comparison. Limnology and Oceanography 47: 427-439.

McMahon, T., R. RAINE, and J. SILKE. 1998. Oceanographic control of harmful phytoplankton blooms around southwestern Ireland, p. 128-129. In B. Reguera, J. Blanco, M. L. Fernández and T. Wyatt [eds.], VII International Conference on Harmful Algal Blooms. Xunta de Galacia and Intergovernmental Oceanographic Commission of UNESCO.

McMahon, T., R. RAINE, O. TITOV, and S. BoYCHUK. 1995. Some oceanographic features of northeastern Atlantic waters west of Ireland. ICES Journal of Marine Science 52: 221-232.

Menden-Deuer, S., E. J. Lessard, J. SATterberg, and D. Grünbaum. 2005. Growth rates and starvation survival of three species of the pallium-feeding, thecate dinoflagellate genus Protoperidinium. Aquatic Microbial Ecology 41: 145-152.

Moran, S., J. Silke, R. Salas, T. Chamberlan, J. Lyons, J. Flannery, V. Thornton, D. Clarke, and L. Devilly. 2005. Review of Phytoplankton Monitoring 2005, p. 4-10, Proceedings of the 6th Irish Shellfish Safety Scientific Workshop. Marine Institute.

NAUSTVOLL, L. J. 2000. Prey size spectra and food preferences in thecate heterotrophic dinoflagellates. Phycologia 39: 187-198.

Raine, R., B. Joyce, J. Richard, Y. Pazos, M. Moloney, K. J. Jones, and J. W. PATCHING. 1993. The development of a bloom of the dinoflagellate Gyrodinium aureolum (Hulbert) on the south-west Irish coast. ICES Journal of Marine Science 50: 461-469. 
RAINE, R., and T. McMahon. 1998. Physical dynamics on the continental shelf off southwestern Ireland and their influence on coastal phytoplankton blooms. Continental Shelf Research 18: 883-914.

Raine, R., S. O'Boyle, T. O'Higgins, M. White, J. W. Patching, B. Cahill, and T. McMahon. 2001. A satellite and field portrait of a Karenia mikimotoi bloom off the south coast of Ireland, August 1998. Hydrobiologia 465: 187-193.

RAINE, R., J. O'MAHONEY, T. McMahon, and C. RoDEN. 1990. Hydrography and phytoplankton of waters of South-west Ireland. Estuarine, Coastal and Shelf Science 30: 579-592.

SMETACEK, V. 1981. The annual cycle of protozooplankton in the Kiel Bight. Marine Biology 63: 1-11.

TILlmanN, U., and K. J. Hesse. 1998. On the quantitative importance of heterotrophic microplankton in the northern German Wadden Sea. Estuaries 21: 585-596.

Tiselius, P., and M. KuYlenstiERnA. 1996. Growth and decline of a diatom spring bloom: Phytoplankton species composition, formation of marine snow and the role of heterotrophic dinoflagellates. Journal of Plankton Research 18: 133-155.

Verity, P. G., P. Wassman, M. E. Frisher, M. H. Howard-Jones, and A. E. Allen. 2002. Grazing of phytoplankton by microzooplankton in the Barents Sea during early summer. Journal of Marine Systems 38: 109-123. 
Chapter 3

Sexual and asexual reproduction in Protoperidinium steidingerae Balech (Dinophyceae) 


\begin{abstract}
In this study, division, sexuality, mandatory dormancy period of hypnozygotes, and identity life-history stages were revealed for the first time for any Protoperidinium spp., using a suite of morphological, histological, and molecular techniques. Asexual division occurred by eleutheroschisis within a temporary, immotile cyst, yielding two daughter cells. Daughter cells were initially round and half to two-thirds the size of parent cells, then rapidly increased in size, forming horns before separating. Sexual reproduction was constitutive in both non-clonal and clonal cultures, indicating that the species may be homothallic. Gametes were isogamous, approximately half the size and lacking the pink pigmentation of the vegetative cells, and were never observed to feed. Gamete fusion resulted in a planozygote with two longitudinal flagella. Hypnozygotes had a mandatory dormancy period of ca. 70 days. Germination resulted in planomeiocytes with two longitudinal flagella. Protargol-stained specimens suggest that nuclear cyclosis may occur in the planomeiocyte. This work suggests that mis-identification of morphologically distinct life history stages and incomplete examination of thecal plate morphology in field specimens of $P$. steidingerae have led to taxonomic confusion.
\end{abstract}




\section{INTRODUCTION}

Protoperidinium Bergh is a cosmopolitan genus of heterotrophic, thecate, marine dinoflagellates with more than 200 described species (Balech 1974). Many Protoperidinium are species-specific selective feeders, with digestion external to the theca, allowing consumption of large phytoplankton, including diatoms and dinoflagellates (Gaines and Taylor 1984; Jacobson and Anderson 1986; Naustvoll 2000). Other Protoperidinium are generalists, and some even consume zooplankton eggs and nauplii (Jeong 1996). These heterotrophs thus likely play an important role in the trophic dynamics of the plankton, perhaps similar to that of mesozooplankton.

Protoperidinium spp. have been the subject of extensive taxonomic investigation for more than 120 years. Examination of the distribution of these heterotrophic dinoflagellates has usually been as part of studies of the plankton community. Because of the complexity of examining thecal plate morphology as is necessary for conclusive identification, the many, diverse species are often grouped together as "Protoperidinium spp." in such projects. In the past 20 years, several laboratory studies have addressed the feeding mechanisms, grazing rates, preferred foods and growth rates of a few Protoperidinium spp. However, because culturing these heterotrophs is difficult and labor intensive little else is known about the autecology of members of the genus.

Knowledge of life history is important for understanding the ecologies of Protoperidinium spp. and the roles they may play in the trophic structure of the plankton. For example, the presence of a sexual cycle and of dormant cysts allows for genetic recombination and dispersal to new areas (Anderson and Wall 1978; Anderson 1998). Additionally, the mandatory dormancy period of cysts, combined with temperature windows for germination and growth, may control the seasonality of a species or whether blooms occur (Anderson and Rengefors 2006). Understanding possible triggers for the induction of sexuality and encystment could indicate environmental factors that might 
control the dynamics of a Protoperidinium sp. population, or the ability of that Protoperidinium sp. to control a phytoplankton bloom through grazing.

Dormant cysts have been identified for many Protoperidinium species, indicating the possible presence of a sexual cycle in at least some members of the genus. These cysttheca relationships have been established by germination in the laboratory of cysts collected in the field. The remainder of the life cycle, including even the mode of asexual reproduction, remains undescribed for all Protoperidinium spp.

Descriptions of different life cycle stages need to be provided for Protoperidinium spp. There is currently no information about how conserved the life cycle characteristics might be among species in this large and diverse genus. Hypnozygotes have not been identified for all species, and it may be that some sexually reproducing species do not form dormant cysts, or that not all species undergo sexual reproduction.

The life history of Protoperidinium steidingerae Balech described here provides the first account of asexual or sexual reproduction for any species of Protoperidinium. In this study, life cycle stages of $P$. steidingerae were examined using cultures isolated from Vineyard Sound, off the coast of Woods Hole, Massachusetts, USA. Asexual division, gamete morphology and fusion, mandatory dormancy and germination rates of hypnozygotes, and the identity of other morphologically distinct life-history stages were revealed using a suite of morphological and molecular tools.

\section{MATERIALS AND METHODS}

\section{Protoperidinium cultures}

A strain of $P$. steidingerae (MV0923-PO-1) was isolated from Vineyard Sound, Massachusetts, north of Martha's Vineyard near Woods Hole, MA, in September of 2004. A second strain (MV0802) was isolated from Vineyard Sound, MA from a sample taken at the Woods Hole Oceanographic Institution dock in August 2005. 
Protoperidinium steidingerae cultures were maintained in $0.2 \mu \mathrm{m}$-filtered, autoclaved seawater from Vineyard Sound (30 psu) with a mixture of Ditylum brightwellii (West) Grunow (CCMP 356) and Chaetocerous affinis Lauder (CCMP 158) as prey. Cultures were contained in $70 \mathrm{~mL}$ tissue culture flasks (Falcon, 353009, Becton Dickinson, Franklin Lakes, NJ) without air space and rotated on a plankton wheel at $1-2 \mathrm{rpm}$ at $15^{\circ}$ $\mathrm{C}$ under low light $\left(50 \mu \mathrm{mol}\right.$ photon $\left.\mathrm{m}^{-2} \mathrm{~s}^{-1}\right)$ on a $14 \mathrm{~h}: 10 \mathrm{~h}$ light:dark cycle. Transfers were made every four to five days by pouring approximately two-thirds the volume of the old culture into a new flask containing fresh sterile-filtered sea water, $4 \mathrm{~mL}$ of $D$. brightwellii (ca. 25,000 cells $\mathrm{mL}^{-1}$ ), and $3 \mathrm{~mL}$ of C. affinis (ca. 400,000 cells $\mathrm{mL}^{-1}$ ).

\section{Phytoplankton cultures}

The diatom cultures used as prey were grown as described in Gribble and Anderson (In press). In brief, D. brightwellii (CCMP 356) and C. affinis (CCMP158) cultures were maintained in tubes with $25 \mathrm{~mL}$ of $\mathrm{f} / 2$ nutrient medium plus silicate (Guillard 1975) at $15^{\circ} \mathrm{C}$. All prey cultures were kept at a photon flux density of ca. $100 \mu \mathrm{mol} \mathrm{m} \mathrm{m}^{-2} \mathrm{~s}^{-1}$, on a $14 \mathrm{~h}: 10 \mathrm{~h}$ light:dark cycle.

\section{Scanning electron microscopy}

Morphological species identification was confirmed by examination of thecal plate structure using SEM. In preparation for SEM, samples of $40 \mathrm{~mL}$ from culture were preserved with borate-buffered formalin ( $5 \%$ final concentration) and stored at $4^{\circ} \mathrm{C}$ at least overnight. Subsamples of $15 \mathrm{~mL}$ were centrifuged (5 min. at $3000 \mathrm{rcf}$ ), aspirated to $1 \mathrm{~mL}$, and brought up to $4 \mathrm{~mL}$ with filtered seawater to remove most formalin. Several

hundred Protoperidinium sp. cells isolated away from phytoplankton prey by micropipette were deposited into $2-\mathrm{mL}$ cryovials with $5 \%$ formalin in filtered seawater and stored at $4^{\circ} \mathrm{C}$ overnight. Samples were drawn down onto filters (Nucleopore tracketched membrane, $13 \mathrm{~mm}, 5 \mu \mathrm{m}$ pore size) and washed with filtered seawater followed by distilled, deionized water to remove fixatives and salts. Cells on filters were dehydrated in a series of ethanol washes of increasing concentration, critical point dried 
(Tousimis Samdri-780A), sputter coasted with gold palladium (Tousimis Samsputter-28), and examined on a scanning electron microscope (JEOL JSM-840).

\section{Sequencing of LSU rDNA}

To confirm the species identity of different Protoperidinium morphologies in culture, the D1-D6 region of the LSU rDNA was amplified by single-cell PCR and sequenced as described in Gribble and Anderson (In press). Single P. steidingerae cells of varying morphologies were isolated from culture by micropipette. Each cell was washed 2-3 times in sterile filtered seawater and 1-2 times in sterile DI water before being deposited individually into a PCR tube in approximately $10 \mu \mathrm{L}$ of sterile DI water. Isolated cells in PCR tubes were frozen at $-80^{\circ} \mathrm{C}$ overnight to enhance cell lysis. To further improve lysis, isolated cells in PCR tubes were immersed in ice water and subjected to a sonification bath at $40 \mathrm{~A}$ for approximately $30 \mathrm{sec}$ immediately before PCR.

The single cells were used directly as template to amplify approximately $1430 \mathrm{bp}$ of the LSU rDNA containing the variable domains D1-D6, using the primers D1R (Scholin et al. 1994) and 28-1483R (Daugbjerg et al. 2000). The 50- $\mu \mathrm{L}$ PCR reaction mixture contained 2.5 units $P f u$, a proofreading DNA polymerase (Stratagene, La Jolla, CA), 5 $\mu \mathrm{L} 10 \mathrm{X}$ buffer (1x final concentration), $0.3 \mu \mathrm{M}$ of each primer, and $200 \mu \mathrm{M}$ dNTPs (Takara, Shiga, Japan). Thermal cycling was conducted using an initial denaturation at $95^{\circ} \mathrm{C}$ for $5 \mathrm{~min}$., 30 cycles of $95^{\circ} \mathrm{C}$ for $1 \mathrm{~min}$., $50^{\circ} \mathrm{C}$ for one min., and $72^{\circ} \mathrm{C}$ for $2 \mathrm{~min}$., followed by a final elongation step of $72^{\circ} \mathrm{C}$ for $10 \mathrm{~min}$.

Between 25-30 $\mu \mathrm{L}$ of PCR product was run on a 1\% agarose gel. Positive bands were excised and the product purified and concentrated using a MinElute Gel Extraction Kit (Quiagen, Valencia, CA). Purified PCR products were cloned separately using the Zero Blunt TOPO PCR Cloning Kit for Sequencing (Invitrogen, Carlsbad, CA). Primers T3, $\mathrm{T} 7$, and an appropriate internal primer (Table 4) were used for sequencing between 12 and 89 clones for each species. Sequencing was done on an Applied Biosystems 3730XL 
capillary sequencer. Sequences were edited using Sequencher 4.5 software and aligned using ClustalX software.

\section{Clonal cross time series}

Two 70-mL clonal cultures of $P$. steidingerae, both without cysts, were combined in a 300-mL tissue culture flask (BD Falcon 353133, Bedford, MA) with $24 \mathrm{~mL}$ of $D$. brightwellii as prey. The flask was filled to the top with sterile seawater, placed on a plankton wheel, and rotated under the culture conditions described above. Subsamples of $5 \mathrm{~mL}$ were withdrawn and preserved with modified Bouin's solution (Coats and Heinbokel 1982) to a final concentration of $5 \%$ at the time of inoculation, at $16 \mathrm{hr}$. after inoculation, thereafter at $24 \mathrm{hr}$. intervals for four days, at $48 \mathrm{hr}$. intervals over the following six days, and finally after an additional $72 \mathrm{hrs}$., for a total of 10 samples over 14 days. After inoculation at 17:00, all sampling was done at approximately 09:00, two hours after the start of the daily light period. To examine nuclear and flagellar morphology, samples were processed using the Quantitative Protargol Staining (QPS) method (Montagnes and Lynn 1993). The entire volume of each sample was stained, and all of the cells in each sample were counted on a Nikon compound microscope at 250X to determine total cell concentration (cells $\mathrm{mL}^{-1}$ ) at each time point. For each sample, between 50-100 cells were further analyzed to determine life history stage. Each cell was photographed at $400 \mathrm{X}$ to $500 \mathrm{X}$ and cell length, cell width, nucleus length, and nucleus width were measured using a calibrated Zeiss AxioCam on a Zeiss Axioskop or Zeiss Axioplan2. The number of nucleoli, transverse and longitudinal flagella, and basal bodies were determined at $1000 \mathrm{X}$ to $1250 \mathrm{X}$. For each sample, the percent of cells of each life history stage was multiplied by total number of cells $\mathrm{mL}^{-1}$ to estimate the concentration of cells in each stage.

\section{Starvation time series}

An additional time series was conducted using a non-clonal strain of $P$. steidingerae (MV0923-PO-1). A 300-mL tissue culture flask (BD Falcon 353133, Bedford, MA) was 
inoculated with $P$. steidingerae, $20 \mathrm{~mL}$ each of $D$. brightwellii and $C$. affinis, and filled to the top with sterile seawater. The flask was rotated under the culture conditions described above. After one week, the flask was taken off the plankton wheel and stood upright for two hours to allow any existing hypnozygotes and diatom food to settle to the bottom. A pipette was used to transfer $225 \mathrm{~mL}$ from the top of the settled culture to a new flask with fresh filtered seawater but no food. The flask was rotated without food for $48 \mathrm{hr}$. under the culture conditions described above. After the period of starvation, the contents of the flask were added to a new flask with $20 \mathrm{~mL}$ each of $D$. brightwellii and $C$. affinis. Two subsamples of $4 \mathrm{~mL}$ were withdrawn and preserved, one with modified Bouin's solution (Coats and Heinbokel 1982) to a final concentration of 5\%, and the other with $5 \%$ formalin (final concentration) at the time of inoculation, every two to seven hours for three days, and once per day for the next two days, for a total of 16 time points. Sampling effort was concentrated in the early morning, just before and just after the beginning of the daily light period. Samples preserved in Bouin's solution were stained using the QPS method (Montagnes and Lynn 1993), and select samples were analyzed by photographing and measuring cells as described above for verification of different life cycle stages.

\section{Planozygote isolations and observations}

To observe encystment directly and to verify the morphology of putative planozygotes in culture, a total of 60 cells of smaller than average vegetative cell size with distally splayed or bent antapical horns and two longitudinal flagella were isolated into either 48well plates or 96-well plates over three different dates. Because isolated P. steidingerae cells had previously been found to perish without rotation and feeding, 35 of the cells were deposited into separate wells of a 96-well plate, with each well filled to the top with sterile seawater and $D$. brightwellii. Silicone grease was used to seal a $25-\mathrm{mm}$ glass coverslip to the top of the well, forming a chamber with no airspace for each isolated cell. The entire 96-well plate was capped, placed on a plankton wheel, and rotated at 1-2 rpm. 
The remaining 25 cells were not rotated or provided with prey. All putative planozygotes were kept at $15^{\circ} \mathrm{C}$, under a $14 \mathrm{~h}: 10 \mathrm{~h}$ light: dark cycle (ca. $50 \mu \mathrm{mol}$ photon $\mathrm{m}^{-2} \mathrm{~s}^{-1}$ ).

\section{Cyst germination}

To investigate the length of the mandatory dormancy period of hypnozygotes, the time to germination was measured for cysts of known age held at a range of temperature conditions. A $70-\mathrm{mL}$ tissue culture flask of non-clonal $P$. steidingerae culture was allowed to stand without rotation for approximately 6 hours, to allow any existing cysts to settle to the bottom. A pipette was used to pull $50 \mathrm{~mL}$ of culture from the top of the flask, leaving the cysts behind. The cyst-free culture was added to a $250-\mathrm{mL}$ tissue culture flask with $15 \mathrm{~mL}$ each of $D$. brightwellii and $C$. affinis. The flask was filled to the top with sterile seawater and rotated on a plankton wheel under the culture conditions described above.

The flask was inspected daily on a dissecting microscope for the appearance of cysts. The first cysts were observed 5 days after inoculation. Eight days after inoculation, the flask was allowed to settle in the incubator for 2 hours. The overlying seawater and swimming cells were removed from the flask by pipette, and the settled cysts were collected from the bottom of the flask. Individual cysts were isolated by micropipette, washed 4 times in sterile seawater, and deposited into separate wells of 96-well plates, each well with $190 \mu 1$ sterile seawater. Single 96-well plates with 34-36 cysts each were placed at each of two temperatures $\left(15^{\circ} \mathrm{C}\right.$ and $20^{\circ} \mathrm{C}$ ) under low light (ca. $50 \mu \mathrm{mol}$ photon $\mathrm{m}^{-2} \mathrm{~s}^{-1}$ ) on a $14 \mathrm{~h}: 10 \mathrm{~h}$ light:dark cycle. One month later, the experiment was repeated, with single plates of 35 cysts each placed at $15^{\circ} \mathrm{C}$ and at $5^{\circ} \mathrm{C}$. All cysts were examined twice weekly until germination was first noted and every two days thereafter. Observations continued until no new cysts had germinated for more than two weeks for plates at $15^{\circ} \mathrm{C}$ and $20^{\circ} \mathrm{C}$, and for one year for cysts held at $5^{\circ} \mathrm{C}$. 


\section{Planomeiocyte morphology}

To examine planomeiocyte morphology and division, cysts formed in a clonal culture of $P$. steidingerae (MV0923-PO-Clone 6) over a one month period were collected and stored at $2^{\circ} \mathrm{C}$ to prevent germination. Nine weeks later, after the mandatory dormancy was expected to be nearing completion based on previous germination experiments, 136 individual cysts were isolated by micropipette into 96-well plates, as described above. Cysts were checked for germination several times per day. Excysted planomeiocytes were either preserved immediately ( $<2 \mathrm{hr}$. post-germination), or isolated into new 96-well plates to monitor growth and division. Because $P$. steidingerae planomeiocytes had previously been found to require rotation and feeding for survival, each isolated cell was deposited in the well of a 96-well plate filled to the top with sterile seawater and $D$. brightwellii, the well was sealed with a coverslip, and the plate was rotated as described above. Planomeiocytes were checked for feeding and division several times per day, and selected individuals were preserved with modified Bouin's solution to a final concentration of $5 \%$ (Coats and Heinbokel 1982) for examination of nuclear and cytological morphology by QPS (Montagnes and Lynn 1993). The cytology of planomeiocytes was thus examined at various times post-germination: less than 2 hours ( 18 cells), 9-18 hours after germination (12 cells), 48-72 hours after germination ( 4 cells), at the two cell stage after the first division ( 24 cells), and at the four cell stage after the second division (10 cells).

\section{Photography and live cell observation}

Live cells were observed in tissue culture flasks and in 96-well plates using a Nikon dissecting microscope or a Zeiss IM35 inverted microscope. Photographs of live and preserved cells on microscope slides, live cells isolated into wells of 96-well plates, and protargol stained specimens were taken using a Zeiss AxioCam on a Zeiss Axioplan2 or on a Zeiss Axioskop, or using a Zeiss Axiovert S100 with a Sony Exwave HAD 3CCD color video camera interfaced with Scion Image 1.62 software. 


\section{RESULTS}

\section{Species identification}

Examination of thecal plate morphology by SEM confirmed the identity of the species under study as $P$. steidingerae Balech. A four-sided apical plate occupied the position of the 1' plate, but was separated from the apex of the cell by a long suture, so that the plates that would usually be designated as 2' and 4' were touching on the ventral side of the cell (Fig 1A). A single, six-sided intercalary plate was present on the dorsal side of the cell, posterior to a small dorsal 3' plate (Fig. 1B-C).

\section{Asexual cycle}

A cross of two clonal cultures of $P$. steidingerae, sampled over two weeks, began with large cells (presumed vegetative cells), small cells (presumed gametes) and dividing cells (presumed mitotic division) (Fig. 2A-B). At the initiation of the experiment, large cells were present at a concentration of 12 cells $\mathrm{mL}^{-1}(50 \%$ of the population), small cells at a concentration of 10 cells $\mathrm{mL}^{-1}(42 \%)$, and dividing cells at a concentration of 1 cell $\mathrm{mL}^{-1}$ (5\%). In a separate experiment, starvation of a culture of $P$. steidingerae for $48 \mathrm{hr}$. led to an increase in the relative abundance of large cell types in the culture, with fewer than $4 \%$ small cells at the first time point.

The large cells in the clonal cross time series averaged $103 \pm 10 \mu \mathrm{m}$ long by $67 \pm 9 \mu \mathrm{m}$ wide (Table 1). Live large cells had a pink pigmentation to the cytoplasm and long, sharply tapering apical and antapical horns. In culture these large cells were witnessed to swim, feed on diatom prey, and divide, but were never seen to fuse together. Large cells stained with protargol had a single pair of basal bodies in the sulcal region associated with a single longitudinal flagellum and a single transverse flagellum. The nucleus of protargol-stained large cells was oval-shaped, averaged $26 \pm 4 \mu \mathrm{m}$ wide and $17 \pm 2 \mu \mathrm{m}$ long, and contained one or two round to oval shaped nucleoli (Fig. 3A). Given the flagellar number and nucleus type, combined with the observations in live cultures these large cells were classified as vegetative cells. 


\section{Figure 1.}

Scanning electron micrographs of Protoperidinium steidingerae cells. Scale bars $=10$ $\mu \mathrm{m}$. (A) Ventral side of $P$. steidingerae cell. Arrow to suture separating 1' plate from apex. (B) Dorsal side of $P$. steidingerae cell. Arrow to single intercalary plate. (C) Side of $P$. steidingerae cell. Arrow points to suture separating small 3' plate from large 1a plate. 


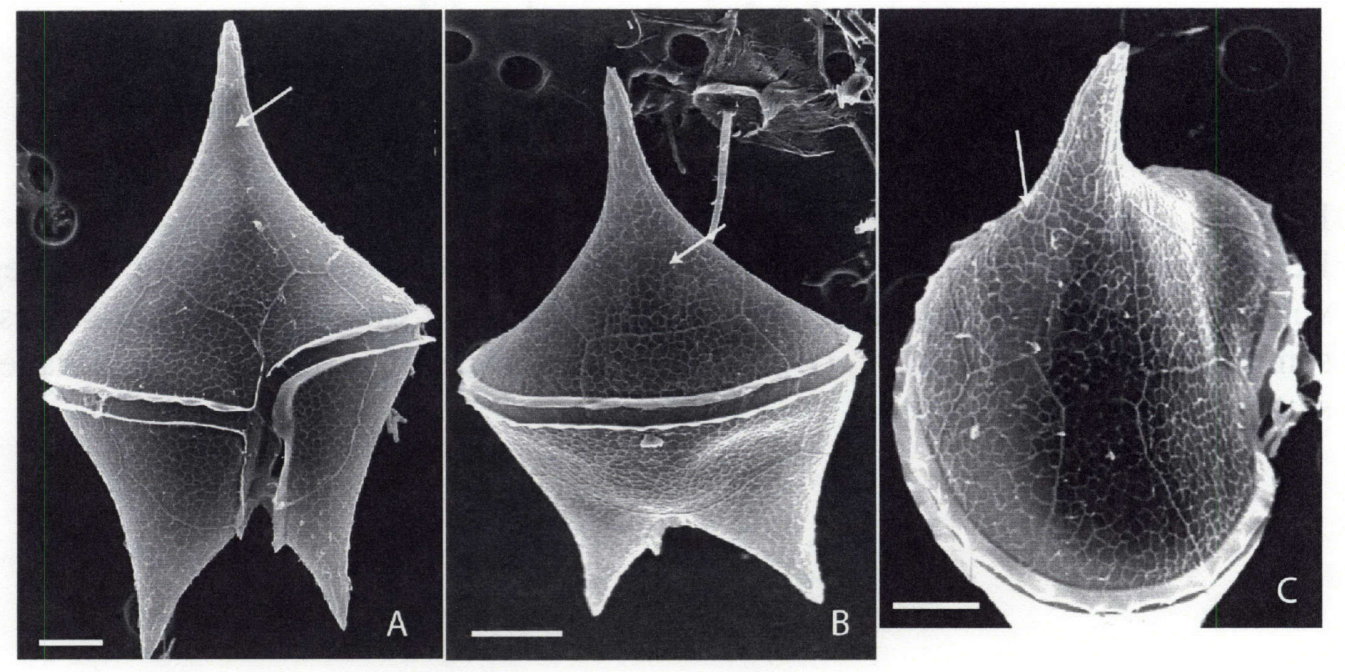


Figure 2.

Results of clonal cross time series sampling of $P$. steidingerae culture that began with vegetative cells and gametes. (A) Concentrations of various life cycle stages at each sampling time, in cells $\mathrm{mL}^{-1}$. (B) Relative abundances of various life cycle stages at each sampling time, in percent. 

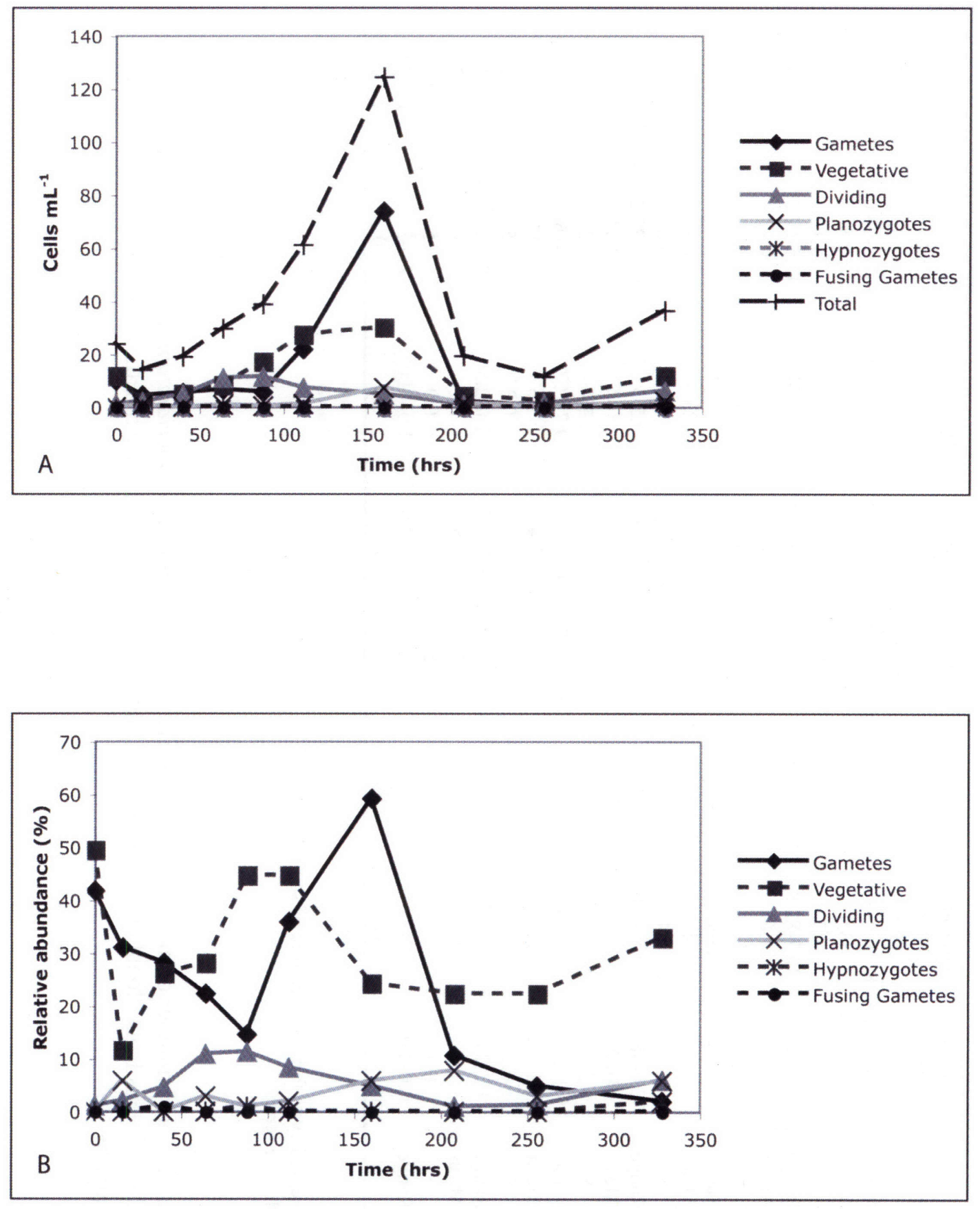


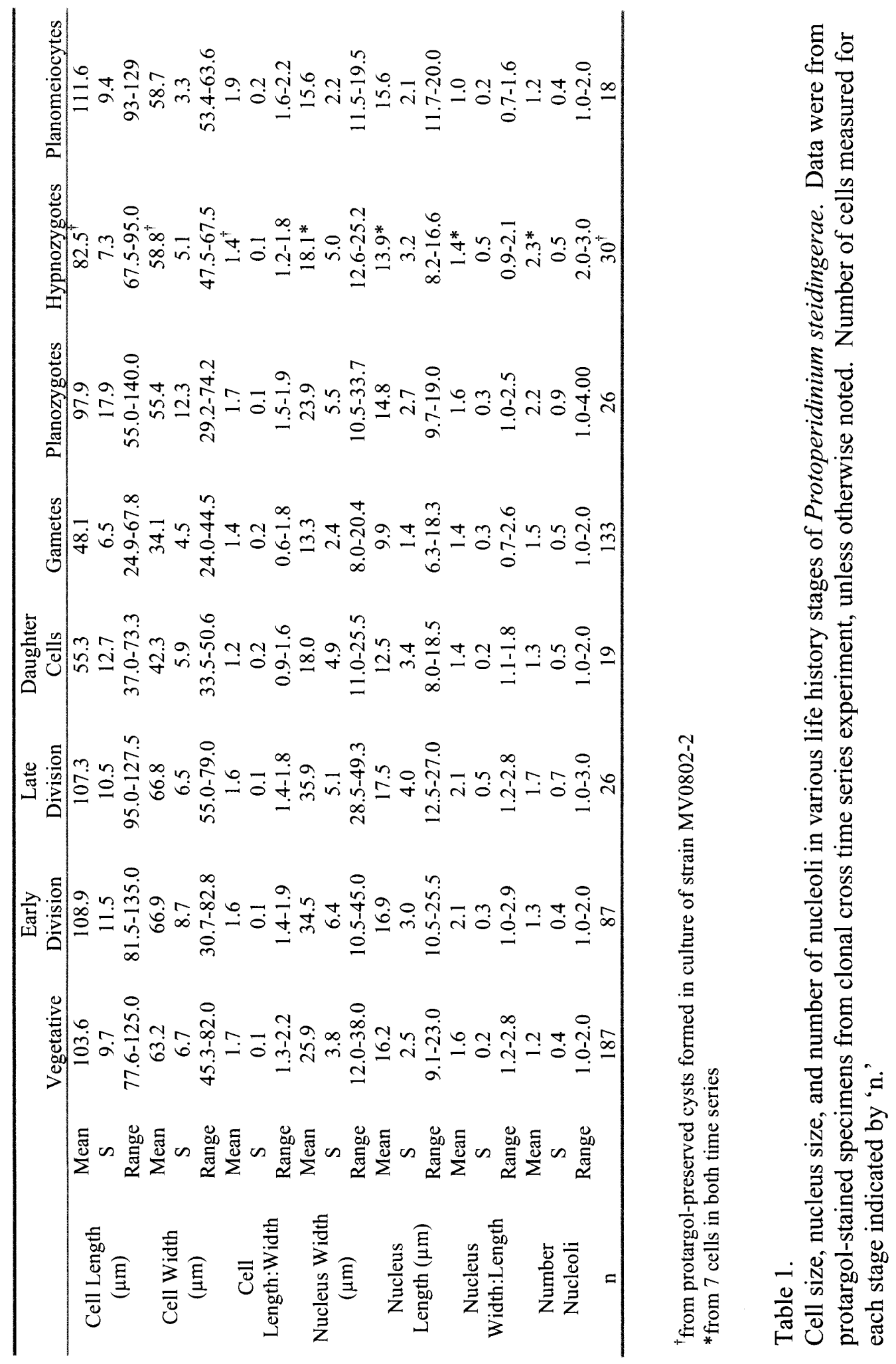


In the clonal cross time series, the concentration of vegetative cells rose considerably through the first half of the time series, reaching a peak of 30 cells $\mathrm{mL}^{-1}(24 \%)$ at 160 hours. The concentration of vegetative cells subsequently declined to 1 cell $\mathrm{mL}^{-1}$ at 208 hr., before increasing slightly to 6 cells $\mathrm{mL}^{-1}$ at the end of the experiment at $328 \mathrm{hr}$.

Asexual reproduction was of the eleutheroschisis type in which binary fission takes place inside the theca of the parent cell, and daughter cells form new thecae rather than share that of the parent. In observations of live cells, the parent cell became immotile and the cytoplasm contracted from the horns and sides of the theca, forming a predivision cyst inside the theca of the parent cell. Flagella were not visible in the division cysts prior to cytokinesis and were presumably lost, resorbed, or simply stopped moving as the parent cell lost motility.

Vegetative cells in varying stages of division were identified from protargol-stained time series samples. From static specimens of similar size, shape, and number of flagella, but with different nuclear morphologies, a likely series of stages leading to division was inferred. In the early stages of division, the nucleus lengthened to an elongate oval that averaged $36 \mu \mathrm{m}$ wide, had a width:length of 2.1 (Table 1), and was oriented obliquely relative to the longitudinal axis of the cell (Fig. 3B). In later stages preceding cytokinesis, the chromosomes within the nucleus formed long, darkly-staining strands oriented generally parallel to one another in an anterior-posterior direction, and the nucleolus or nucleoli stretched and became irregularly-shaped (Fig. 3C). As division progressed, the nucleus became nearly rectangular, and the chromosomes appeared to be separating in an apical-antapical orientation along the center of the nucleus (Fig. 3D). These specimens had a single longitudinal flagellum and a single transverse flagellum. Two pairs of basal bodies were visible indicating that the basal bodies had replicated prior to cytokinesis. 
Figure 3.

Asexual division in Protoperidinium steidingerae. Scale bars $=20 \mu \mathrm{m}$. (A) Protargol stained vegetative cell with one trailing flagellum (solid arrow), one transverse flagellum (dotted arrow), and an oval shaped nucleus. (B) Protargol stained cell with elongate nucleus. Nucleus oriented obliquely across longitudinal axis of cell, chromosomes staining. (C) Close-up of staining chromosomes in another replicating cell. (D) Late stage of mitosis, nucleus oriented obliquely and dividing across the center. (E) Live vegetative cell undergoing eleutheroschisis. Division cyst has formed inside parental theca, cytokinesis occurring, with cytoplasm dividing obliquely across longitudinal axis. (F) Protargol-stained division cyst. Cytokinesis and karyokinesis occurring. (G) Recently divided daughter cells from the same specimen as in (E). Apical and antapical horns not yet developed. $(\mathrm{H})$ Later stage in development of same daughter cells as in (E) and (G). Apical and antapical horns developing, cells remain attached. 


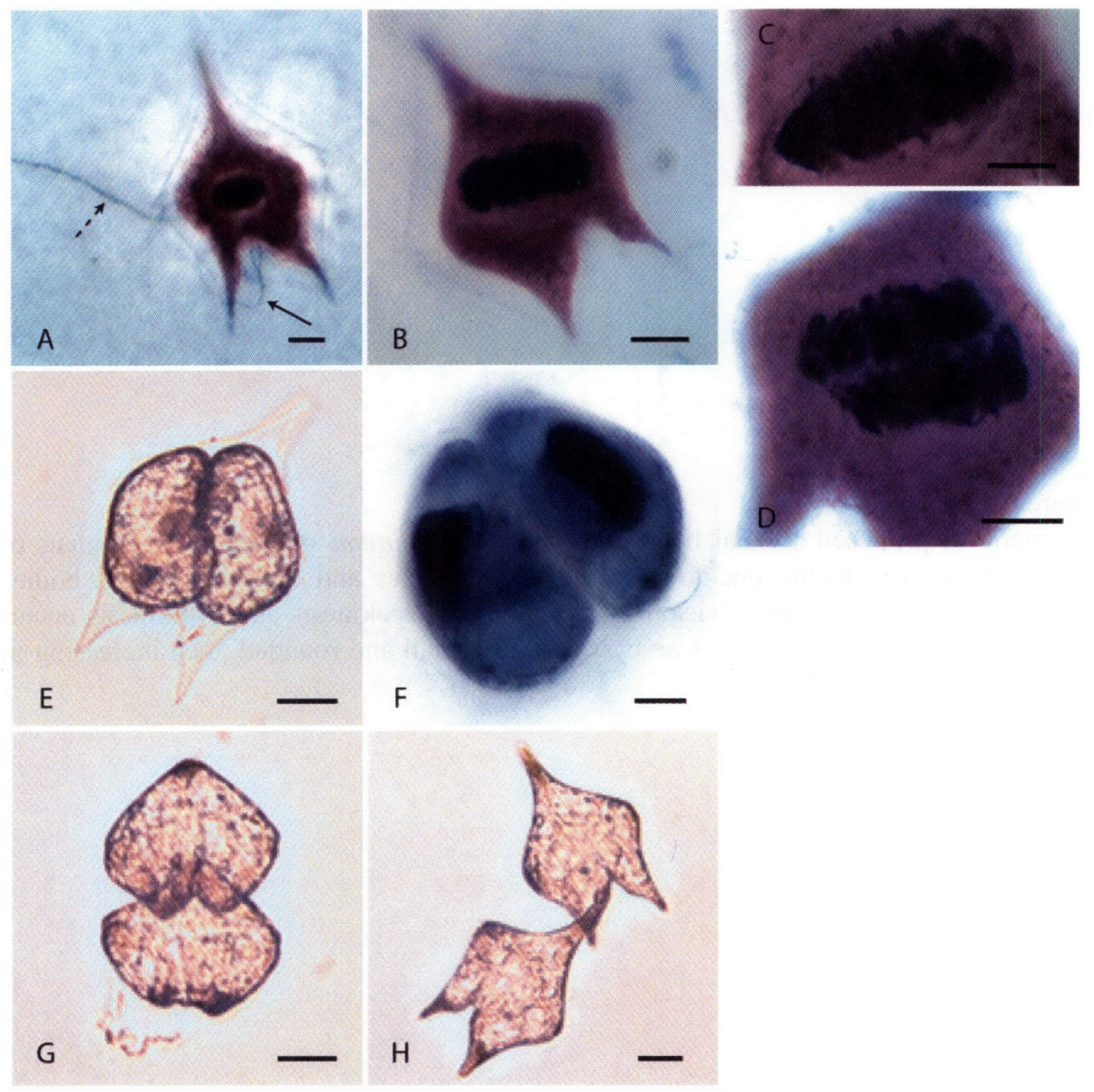


Figure 4.

Schematic of proposed asexual life cycle of Protoperidinium steidingerae. Nucleus of vegetative cell containing one to two nucleoli elongates and divides as basal bodies replicate. Parent cell forms division cyst, in which karyokinesis and cytokinesis occur. Daughter cells emerge from division cyst, initially small and rounded, then increasing in size before separating. 


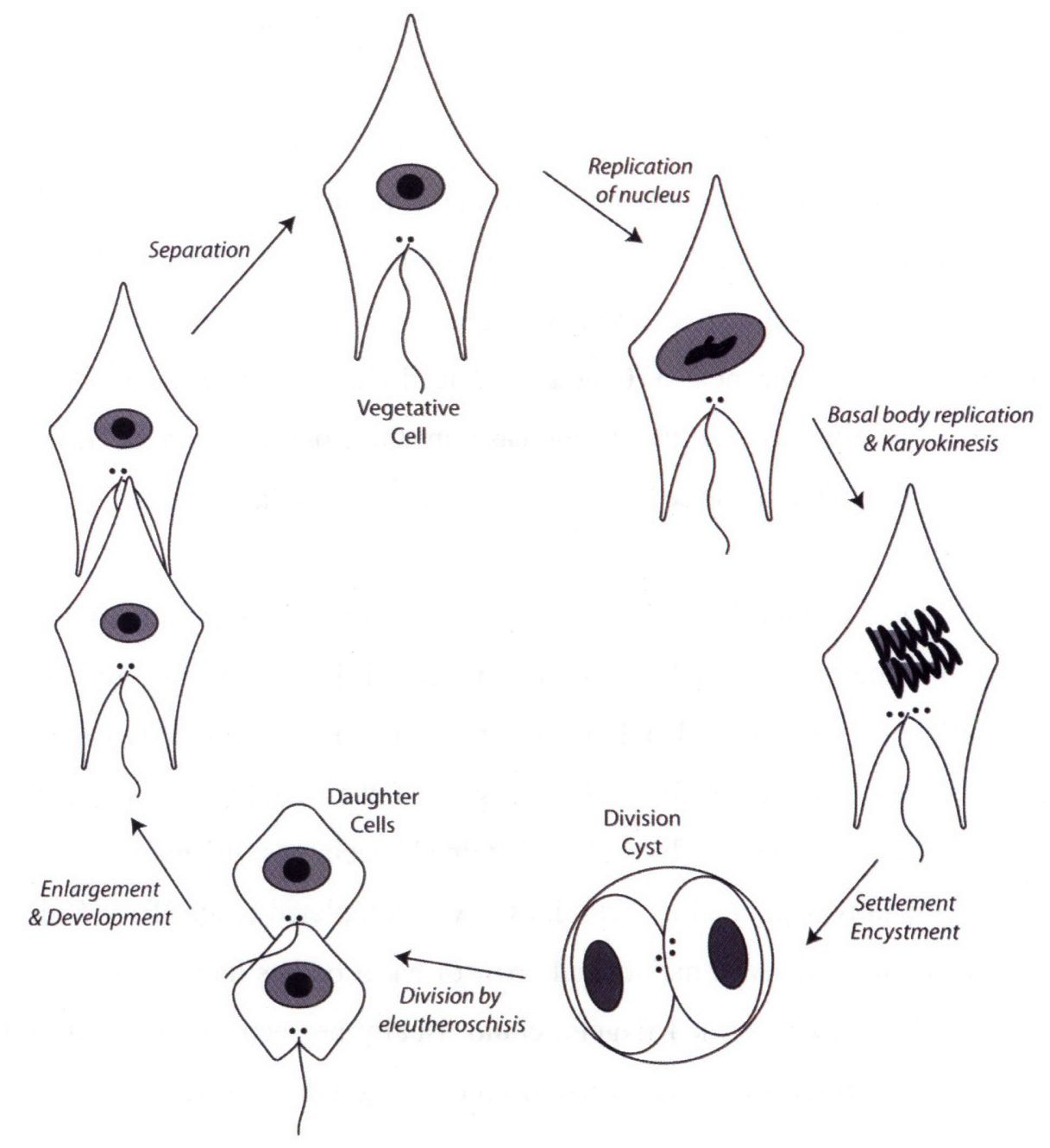


In protargol-stained samples it was apparent that karyokinesis began before cytokinesis, as the nucleus elongated and pulled apart at the center (Fig. 3D). The nucleolus or nucleoli were often difficult to see at this stage, as the entire nucleus stained very darkly. Karyokinesis was not fully complete before cytokinesis commenced.

In the clonal cross time series (Fig. 2), the concentration of dividing cells increased sharply through the first 88 hours of the experiment from 1 cell $\mathrm{mL}^{-1}(5 \%$ of the population) to 11 cells $\mathrm{mL}^{-1}$ ( $29 \%$ of the population) concurrent with the increase in the concentration of vegetative cells, then gradually declined to 1 cell $\mathrm{mL}^{-1}(12 \%$ of the population) over the next 170 hours. The dividing cells appeared to be undergoing asexual division, as the initial increase in the concentration of dividing cells was concurrent with the increase in the concentration of vegetative cells.

In live cells, cytokinesis began with invagination of the cytoplasm at two opposite points along the edge of the cell. Within a period of 10 to $30 \mathrm{~min}$. after the cell became immotile, the cell divided obliquely across the longitudinal axis of the parent theca, forming two lobes (Fig. 3E). The cinguli of the daughter cells became apparent as grooves in the two lobes. In protargol stained specimens, the nuclei of the two daughter cells were fully separated as cytokinesis was completed (Fig. 3F). Within the division cyst, daughter cells each had a single pair of basal bodies located near the adjacent edge of the cell. Newly formed flagella could usually be seen in each cell, although it was difficult to distinguish the transverse from the longitudinal flagellum.

As the daughter cells began to move in a live division cyst, the parental theca appeared to dissolve until only a membrane-like structure surrounded the daughter cells. The daughter cells that emerged from the parental membrane-like enclosure were one-third to one-half the size of the parent cell, averaging $55 \pm 13 \mu \mathrm{m}$ long by $42 \pm 6 \mu \mathrm{m}$ wide (Table 1), had pink pigmentation like the parent cell, were weakly thecate or athecate, and were relatively amorphous, lacking the pronounced apical and antapical horns and sulcal or 
cingular lists of vegetative cells (Fig. 3G). The cells were attached with the apical horn of the posterior daughter cell connected to the sulcal region of the anterior daughter cell, though the two cells were able to spin and articulate relative to one another. Within 10 to 20 minutes, the daughter cells increased in size and expanded their apical and antapical horns, growing to a size near that of typical vegetative cells (Fig. $3 \mathrm{H}$ ). The daughter cells separated at varying stages of development, either detaching while still rounded or remaining attached until nearly fully-developed vegetative morphology had been attained. A schematic of the full asexual cycle for $P$. steidingerae is shown in Fig. 4.

\section{Sexual cycle}

Division of smaller than average vegetative-type cells by eleutheroschisis resulting in very small daughter cells was witnessed, particularly in older cultures, and was presumed to be gametogenesis. In both live cultures and in protargol-stained samples, presumptive gametes could be distinguished from recently divided daughter cells, as gametes were small but heavily thecate with pink pigmentation, whereas recently divided, vegetative daughter cells were relatively athecate, with rounded horns and with a relatively smaller length:width ratio until they increased in size (Fig. 5A, Table 1). The small cells were never observed to feed. Fusion of pairs of small cells was seen frequently in live cultures, confirming the status of these morphotypes as gametes.

In the clonal cross time series, protargol-stained small cells that had the same morphology as live gametes ranged in size from $25 \mu \mathrm{m}$ to $68 \mu \mathrm{m}$ and had a single trailing flagellum, a single transverse flagellum, and one pair of basal bodies. The nucleus in such cells was round to oval in shape, averaging $13 \pm 2 \mu \mathrm{m}$ wide and $10 \pm 1 \mu \mathrm{m}$ long, and containing one or two round nucleoli (Table 1, Fig. 5B).

Because of the differences in the gross morphologies of the vegetative cells and small cells in culture, we used molecular methods to verify the species identification of the 
Figure 5.

Gametes of Protoperidinium steidingerae. (A) Two recently divided daughter cells, still attached, and gamete cell, demonstrating difference between cell types in size, shape, development of theca, and pigmentation. Scale bar $=20 \mu \mathrm{m}$. (B) Protargol-stained gamete with single trailing flagellum (solid arrow) and single transverse flagellum (dashed arrow) and round-oval nucleus. Scale bar $=10 \mu \mathrm{m}$. (C) Protargol-stained gametes in early stage of sexual fusion. Conjugation tube extending between two cells indicated by arrow. Scale bar $=20 \mu \mathrm{m}$. (D) Close up of conjugation tube between the cells in (C). Scale bar $=10 \mu \mathrm{m}$. (E) Different pair of protargol-stained gametes in early stage of sexual fusion. Conjugation tube indicated by arrow. Scale bar $=20 \mu \mathrm{m}$. (F) Live gametes in later stage of fusion. Apical and antapical horns of two cells visible, two longitudinal flagella visible and indicated by arrow. Scale bar $=20 \mu \mathrm{m}$. (G) Protargol stained gametes in late stage of fusion. Two nuclei indicated by arrows. Apical and antapical horns protruding from edges of fusing cells. Scale bar $=10 \mu \mathrm{m}$. 


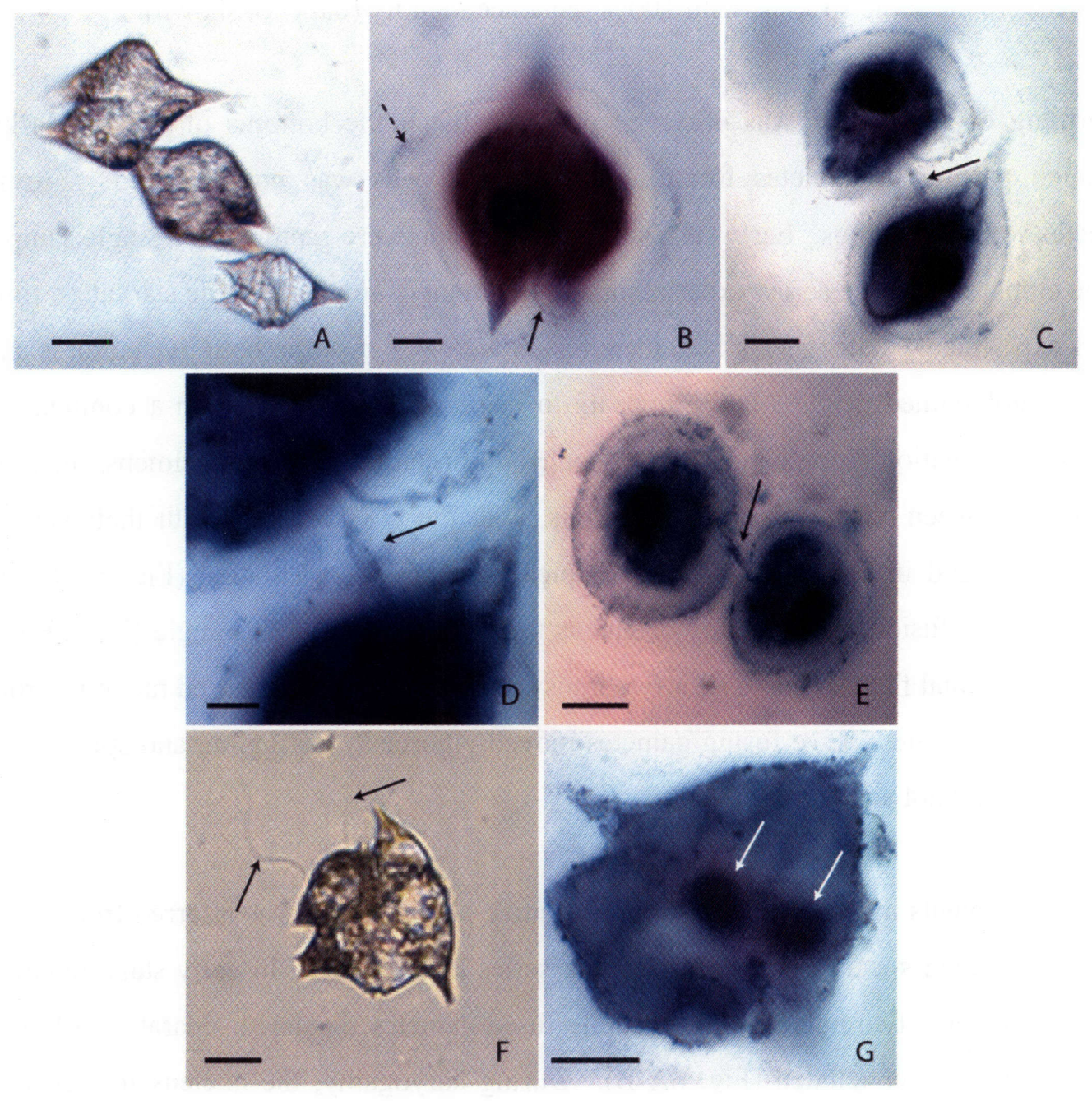


different morphotypes in culture. PCR and sequencing of the D1-D6 region (ca. $1430 \mathrm{bp}$ ) of the LSU rDNA of large cells with a typical vegetative morphology and of small cells with a typical gamete morphology confirmed that the two different morphotypes in the culture were the same species, with $100 \%$ sequence identity (data not shown).

Swarming of small cells was observed occasionally at the bottoms of culture flasks, although pairing of gametes from these swarming cells was not observed. Fusing gametes were isogamous. Early stages of gamete fusion were captured in a single sample in the clonal cross time series experiment and in another sample from the starvation time series experiment. Later stages of gamete fusion were witnessed in both live cultures and in protargol-stained cells. Mating appears to begin via connection with a conjugation tube, or conjugation globule (sensu von Stoch). In protargol-stained specimens, the tube extended between sulcal regions of the cells, with the cells oriented with their ventral sides facing and in a parallel to oblique apical-to-antapical orientation (Fig. 5C-E). In later stages of fusion, plasmogamy occurs as the cells merge at a $90^{\circ}$ angle (Fig. 5F-G). Two longitudinal flagella and one or two transverse flagella were observed radiating from live, paired gametes. Live fusing gametes moved vigorously, wriggling and spinning in circles, but did not swim directionally.

A series of events in the formation of presumptive planozygotes was inferred from static protargol-stained specimens in the two time series experiments. In early stage putative planozygotes, the two nuclei of the recently fused gametes remained separate until after plasmogamy had concluded (Fig. 6A-B). During karyogamy, the nucleus formed two lobes (Fig. 6C), before coalescing into a single, oval-shaped nucleus (Fig 6E). The nucleoli remained separate at least initially, but seem to have fused eventually, as presumptive planozygotes had between 1 to 4 nucleoli.

Protargol-stained putative planozygotes from the clonal cross time series had two pairs of basal bodies lying together at the base of the sulcus (Fig. 6D), two fully developed 
longitudinal flagella and one transverse flagellum, and a large oval-shaped nucleus averaging $24 \pm 6 \mu \mathrm{m}$ wide by $15 \pm 3 \mu \mathrm{m}$ long with between 1 and 4 nucleoli (averaging more than 2 nucleoli per cell) (Fig. 6B-E). In these cells, the second transverse flagellum had presumably been lost during gamete fusion. Planozygotes were smaller than vegetative cells, averaging $98 \pm 18 \mu \mathrm{m}$ long by $55 \pm 12 \mu \mathrm{m}$ wide (Table 1 ).

In live cultures, planozygotes could be distinguished by their two longitudinal flagella and single transverse flagellum. The apical and antapical horns of planozygotes often appeared to be longer and thinner than those of vegetative cells, although the average cell length:width ratio was not different than that of vegetative cells. The cytoplasm in planozygotes was less pigmented than in vegetative cells. Some live planozygotes were smaller than average, had relatively clear pigmentation, and had shorter antapical horns that were bent or splayed distally (Fig. 6F). Given their small size and "lumpy" appearance, we hypothesized that these were early stage planozygotes, the result of recent gamete fusion.

Planozygotes were not detected at the initiation of the clonal cross time series experiment, and appeared only after the gametes of the two clonal cultures were mixed (Fig. 2). Concentrations of planozygotes were low from 16 hours until 160 hours at which time the concentration increased by 5 times, to 7 planozygotes $\mathrm{mL}^{-1}(6 \%$ of the population), simultaneous to the peak in the concentration of gametes.

Sexual reproduction was homothallic, with all sexual stages and dormant cysts forming in clonal cultures. While gametes were usually present in high proportions in clonal cultures, there were often relatively few hypnozygotes in these cultures. Casual observations of cultures indicated that non-clonal cultures and crosses of different clonal cultures usually resulted in greater production of dormant hypnozygotes. 
Figure 6.

Protargol-stained planozygotes of Protoperidinium steidingerae. (A) Planozygote in which plasmogamy was complete, but karyogamy had not occurred and the two nuclei were separate. Scale bar $=10 \mu \mathrm{m}$. (B) Close up of two longitudinal flagella in cell (A). Scale bar $=10 \mu \mathrm{m}$. (C) Planozygote in intermediate stage of karyogamy. Nuclei were fusing, forming a single nucleus with two lobes. Two trailing flagella and one transverse flagellum were visible. Scale bar $=20 \mu \mathrm{m}$. (D) Close up of two pairs of basal bodies in planozygote shown in (C). Scale bar $=10 \mu \mathrm{m}$. (E) Planozygote with single oval shaped nucleus, after karyogamy completed. Two trailing flagella and one transverse flagellum visible. Scale bar $=40 \mu \mathrm{m}$. (F) Early stage planozygote with small size, distally-splayed antapical horns narrow apical horn, and two longitudinal flagella. Scale bar $=20 \mu \mathrm{m}$. 


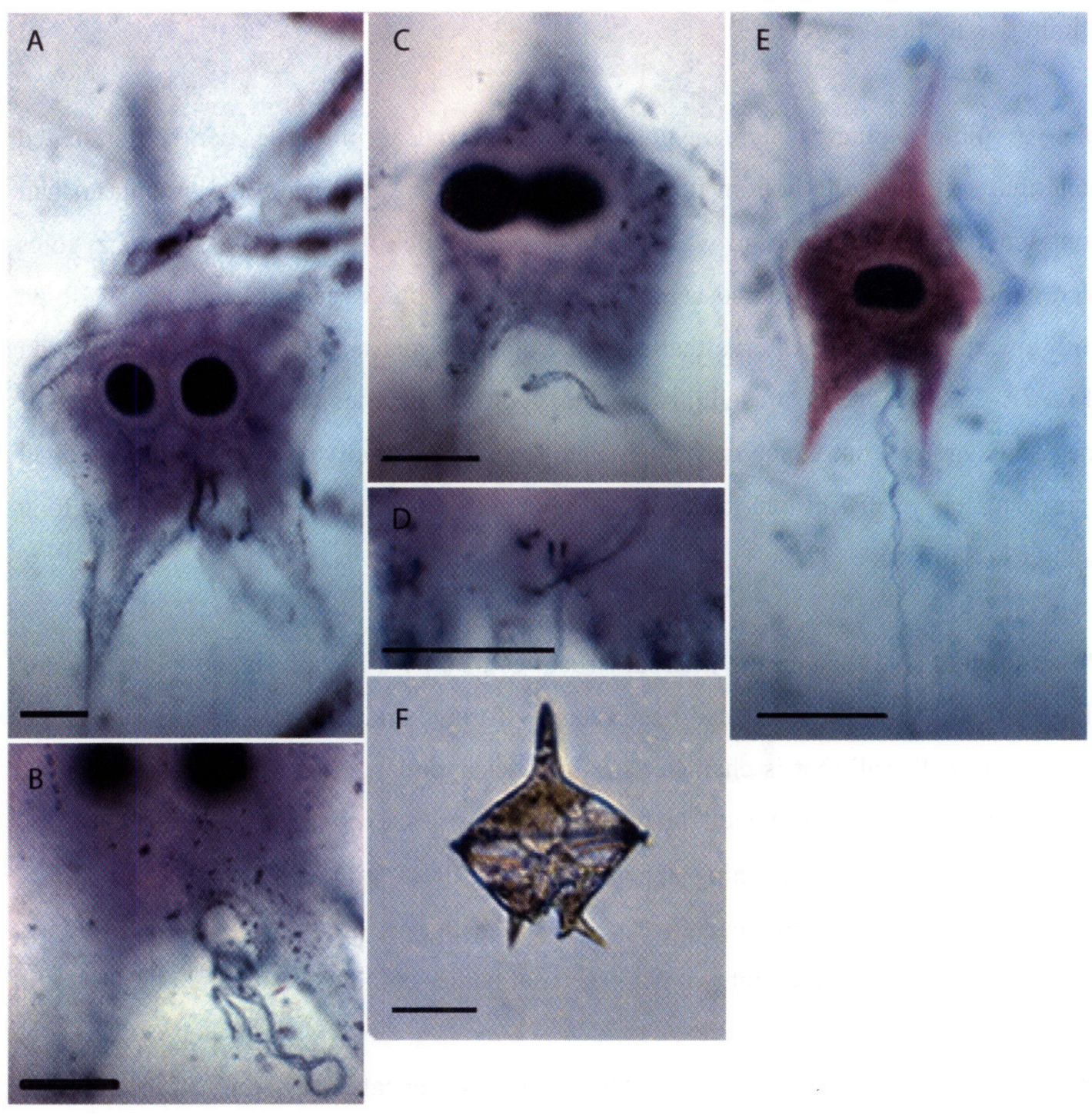


Despite isolation and observation of 60 putative planozygotes, hypnozygote formation was never directly witnessed. No feeding or division was observed in any isolated planozygotes. All of the planozygotes isolated, whether rotated or stationary, died within two to three days.

In live cultures, putative hypnozygotes were observed as immotile, darkly pigmented cells that settled to the bottom of the culture flask. In these cells, the cytoplasm had contracted from the theca and was surrounded by a thick wall. Putative hypnozygotes were smooth-walled and dorso-ventrally compressed, but varied in gross morphology, with apical and antapical horns that ranged from long and narrow to short and rounded (Fig. 7A-C). In cultures, presumptive hypnozygotes sometimes remained in the thecae of the planozygotes from which they originated (Fig. 7A). Putative hypnozygotes averaged approximately $83 \pm 7 \mu \mathrm{m}$ long by $59 \pm 5 \mu \mathrm{m}$ wide, but ranged in size from $68-95 \mu \mathrm{m}$ long and 48 - $68 \mu \mathrm{m}$ wide (Table 1 ).

Protargol was able to stain the internal structures of only a few presumed hypnozygotes (Fig. 7D-E), likely those that had been recently formed and had not yet constructed the recalcitrant cell wall that is characteristic of older hypnozygotes. In the seven putative hypnozygotes that were stained in the two time series experiments, the nucleus was contracted into a darkly-staining sphere averaging $18 \pm 5 \mu \mathrm{m}$ wide by $14 \pm 3 \mu \mathrm{m}$ long, smaller than the nuclei of vegetative cells, and with two or three nucleoli (Table 1). These cells lacked flagella, but two pairs of basal bodies could be seen (Fig. 7E).

In the clonal cross time series, the first hypnozygotes appeared at $88 \mathrm{hr}$., $72 \mathrm{hr}$. after the appearance of the first planozygote (Fig. 2). The concentration of hypnozygotes was very low, and often undetectable through the remainder of the experiment, never exceeding 1 cell $\mathrm{mL}^{-1}$. The presence of two pairs of basal bodies and two or more nucleoli in protargol stained cysts plus the formation these cells only after the appearance 
of planozygotes in the clonal cross time series indicates that they were true hypnozygotes, the products of diploid planozygotes formed by sexual reproduction.

Hypnozygotes of known age were incubated at different temperatures to determine the length of the mandatory dormancy period before germination. Hypnozygotes of $P$. steidingerae averaged 67 to 74 days after formation before germination occurred, indicating the presence of a mandatory dormancy period of approximately 10 weeks. The time to germination was affected slightly by the temperature of incubation of the hypnozygotes. At $15^{\circ} \mathrm{C}$, cysts germinated after an average of $74.6 \pm 10.6$ days and $71.6 \pm 10.1$ days in the two trials. Cysts incubated at $20^{\circ} \mathrm{C}$ matured only slightly more quickly, averaging 67.9 \pm 9.7 days. Cysts incubated at $5^{\circ} \mathrm{C}$, however, did not germinate even after one year (Fig. 8). Maximum germination was approximately $80 \%$ at $20^{\circ} \mathrm{C}$. In two separate tests of germination at $15^{\circ} \mathrm{C}$, although the rates of germination were similar, maximum germination only reached $57 \%$ in the second trial compared with $83 \%$ in the first trial.

Germination of hypnozygotes was frequently witnessed during the cyst mandatory dormancy and the planomeiocyte morphology experiments. The empty wall of germinated hypnozygotes had an intercalary archeopyle with an attached operculum (Fig 7C, F). The opening was six-sided, but in some specimens appeared almost as a curving slit, as the operculum usually remained slightly covering the archeopyle. As the planomeiocytes emerged from the cyst wall, one or both antapical horns often became stuck (Fig. 9A). Sometimes the cell would die, lodged in the cyst wall. Often, one antapical horn would break off in the cyst wall, leaving the planomeiocyte with a longer right antapical horn and a shorter, stubby left horn (Fig. 9B). The gross morphology of planomeiocytes was otherwise similar to that of vegetative cells. Planomeiocytes ranged in size from $93-129 \mu \mathrm{m}$ long and $53-64 \mu \mathrm{m}$ wide, with a cell length:width ratio of 1.9 , slightly higher than that of any other stage (Table 1). Planomeiocytes had two longitudinal flagella and one transverse flagellum (Fig. 9C). 
Figure 7.

Hypnozygotes of Protoperidinium steidingerae. (A) Live hypnozygote inside anterior half of planozygote theca. Apical and antapical horns pointed. Scale bar $=20 \mu \mathrm{m}$. (B) Live hypnozygote with rounded apical and antapical horns. Scale bar $=20 \mu \mathrm{m}$. (C) SEM image of hypnozygote. Six-sided intercalary archeopyle indicated by arrow. Scale bar = $20 \mu \mathrm{m}$. (D) Protargol-stained recently encysted hypnozygote with round, compact nucleus. Scale bar $=10 \mu \mathrm{m}$. (E) Close-up of sulcal region of hypnozygote shown in (D). Two pairs of basal bodies indicated by arrow. Scale bar $=10 \mu \mathrm{m}$. (F) Empty hypnozygote wall. Archeopyle with attached operculum indicated by arrow. Scale bar $=$ $10 \mu \mathrm{m}$. 

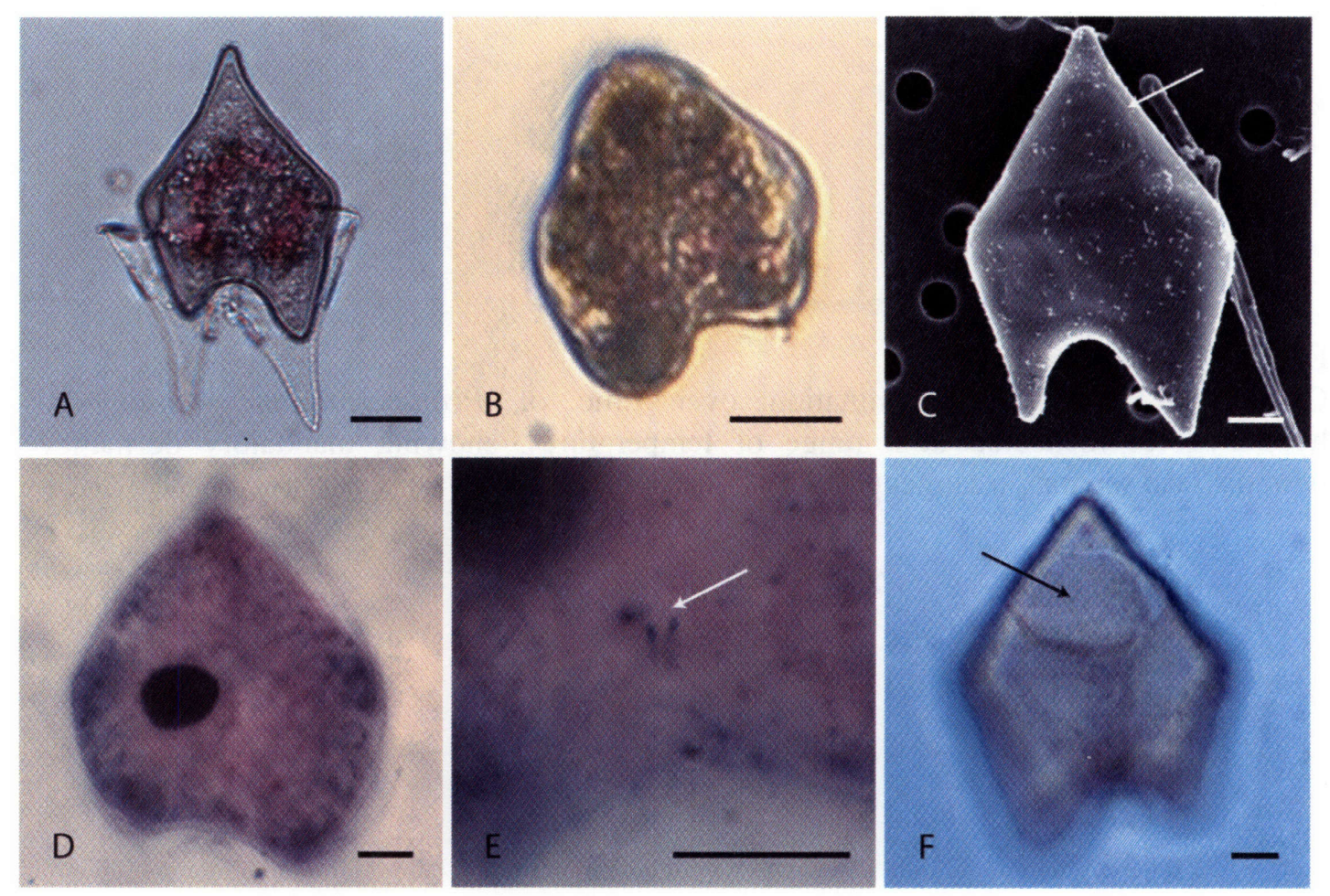
Figure 8.

Cumulative percentage germination over time of Protoperidinium steidingerae hypnozygotes incubated at a range of temperatures, showing mandatory dormancy period. Two separate treatments at $15^{\circ} \mathrm{C}$ are both shown. 


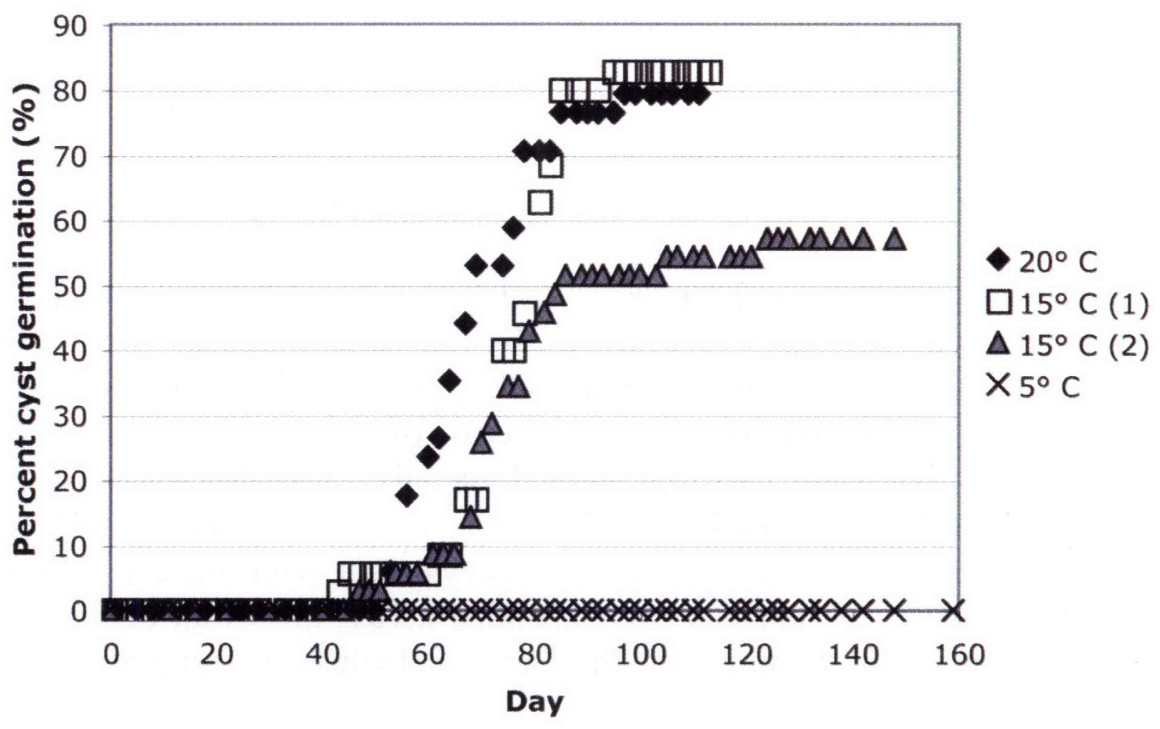


Figure 9.

Planomeiocytes of Protoperidinium steidingerae. Scale bars $=20 \mu \mathrm{m}$. (A) Live, excysting planomeiocyte, with cell stuck in cyst wall by left hand antapical horn. This cell later died, unable to free itself from the cyst wall. (B) Live planomeiocyte with shorter left-hand antapical horn, broken during process of excystment. (C) Live planomeiocyte with arrow indicating two longitudinal flagella. (D) Protargol-stained, recently excysted planomeiocyte with small, round nucleus and two longitudinal flagella. (E) Protargol-stained planomeiocyte, ca. 72 hrs. after excystment with nuclear features indicative of nuclear cyclosis. The nucleus was expanded across the width of the cell, chromosomes had a grainy, dark staining, and the large nucleolus was centered in the nucleus. 


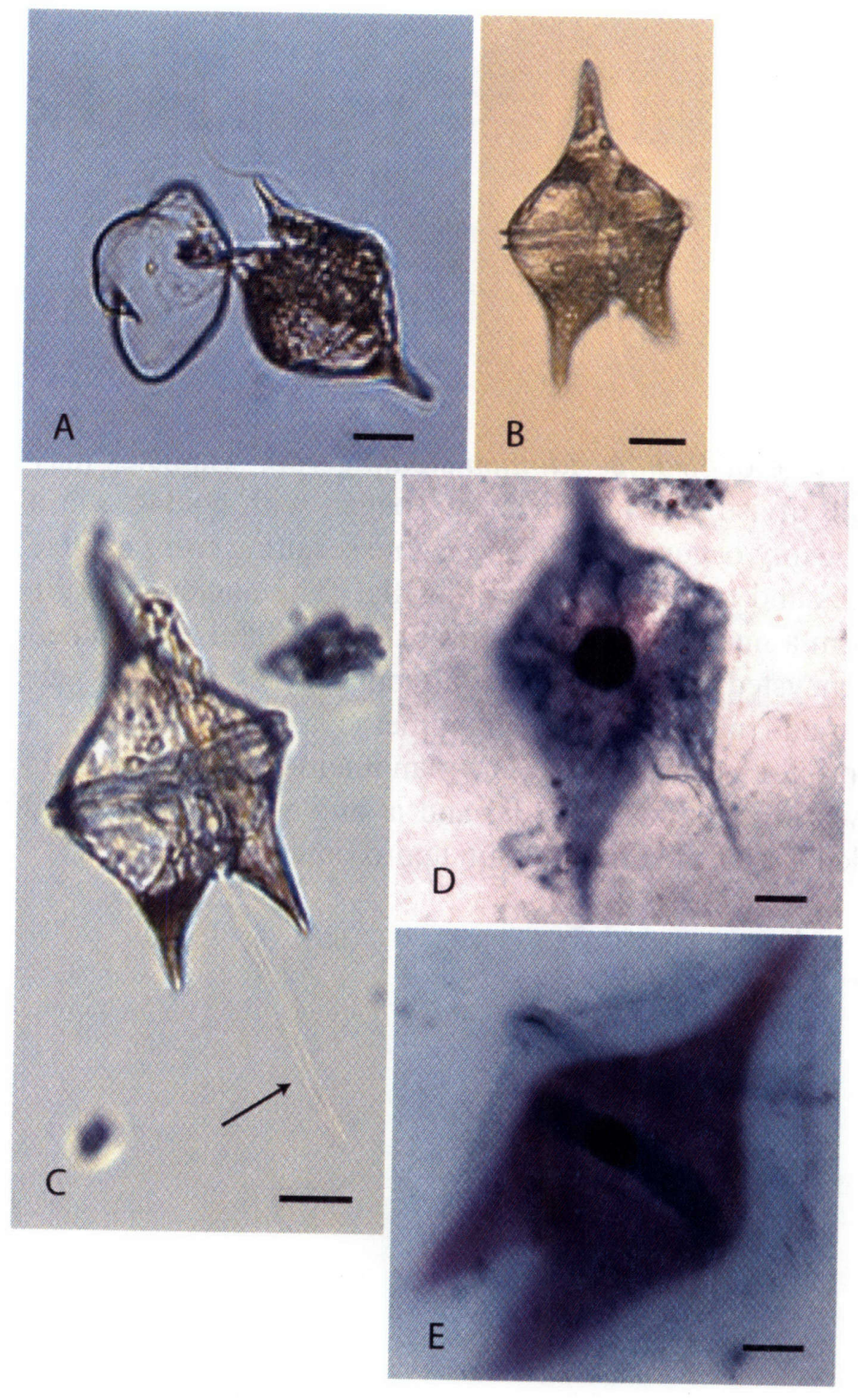


Figure 10.

Schematic of proposed sexual life cycle of Protoperidinium steidingerae. Gametes may have formed through a depauperate division. Gamete fusion began with contact via a conjugation tube before full plasmogamy occurs. The planozygote resulting from gamete fusion had two pairs of basal bodies and two longitudinal flagella. The nuclei from the two gametes gradually fused to form a nucleus containing all of the nucleoli contributed by the gametes. The planozygote encysted, forming dormant hypnozygotes with two pair of basal bodies and a compact, round nucleus. The planomeiocyte excysted after a mandatory dormancy period of approximately 70 days. The planomeiocyte had two pairs of basal bodies associated with two longitudinal flagella, and a single, compact, round nucleus. The planomeiocyte divided for the first time within approximately 4 days. 


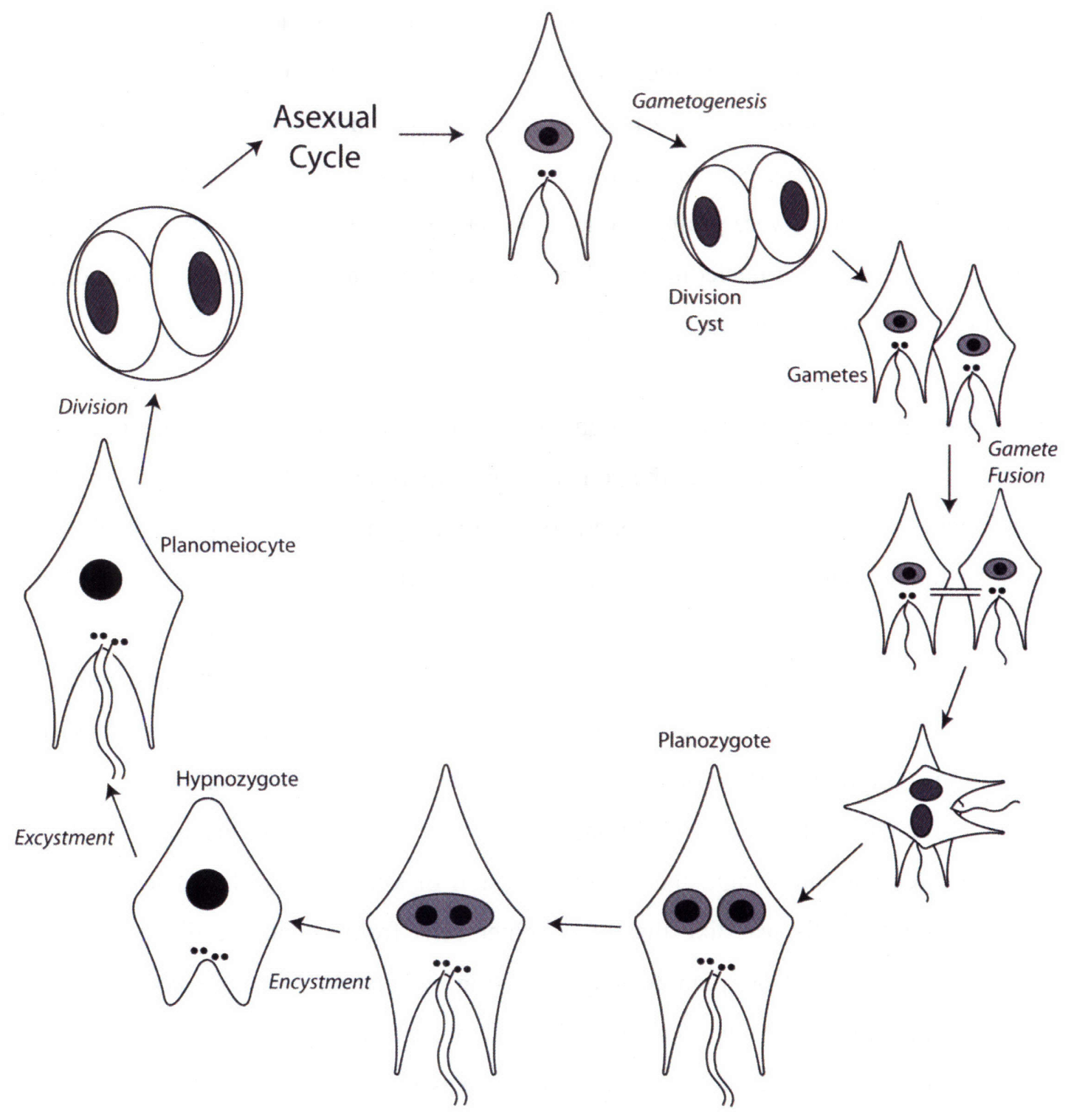


Two pairs of basal bodies were present, but were often not as readily visible as in planozygotes.

As in the hypnozygotes, the nuclei of protargol-stained planomeiocytes were compact and round, approximately $16 \pm 2 \mu \mathrm{m}$ in diameter, with one or two nucleoli that were often difficult to see in the darkly stained nucleus (Fig. 9D). In a single protargol-stained specimen sampled approximately 72 hours post-germination however, the nucleus was 39 $\mu \mathrm{m}$ wide and $11 \mu \mathrm{m}$ long, stretching across the entire width of the cell (Fig. 9E). The contents of the nucleus were grainy, rather than darkly staining and filamentous as in a dividing cell. The single nucleolus was large and centered in the nucleus. This nuclear morphology was not seen in any other stage.

Planomeiocytes were undetectable throughout the clonal cross time series, indicating that no hypnozygotes germinated over the course of the experiment. This result supports the finding that hypnozygotes have a mandatory dormancy period of approximately 10 weeks, far longer than the two-week clonal-cross time series.

Living planomeiocytes were often observed to feed prior to division. Planomeiocytes that were not rotated did not feed and did not divide, dying within several days of germination. The first division occurred three to seven days after germination, averaging just over four days. Division of planomeiocytes was by eleutheroschisis, and in live planomeiocytes was indistinguishable from division of vegetative cells. The size and shape of daughter cells was like that of daughter cells from vegetative division. The nuclei of daughter cells from planomeiocyte division were larger and more elongate than those of the planomeiocytes, with an average width of $21 \mu \mathrm{m}$ and an average length of 17 $\mu \mathrm{m}$. The average width:length ratio of the nucleus was 1.3 - halfway between that of 1.0 in planomeiocytes and 1.6 in vegetative cells. The nucleolus was usually shifted to one side of the nucleus in planomeiocyte daughter cells. The second planomeiocyte division occurred within one to two days of the first division, and the resulting cells had the same 
morphology as vegetative cells. A diagram summarizing the sexual life cycle of $P$. steidingerae is shown in Fig. 10.

\section{DISCUSSION}

This study described for the first time the life history of a species of Protoperidinium. An array of techniques, including live observations, time series sampling, histological staining, morphological analysis by SEM, and identification by single-cell PCR and sequencing, allowed elucidation of a major portion of the life history of $P$. steidingerae in culture. Observations made indicated that the life cycle of $P$. steidingerae is similar to that of other dinoflagellates, including both asexual reproduction by eleutheroschisis and a sexual cycle with isogamous gametes and dormant hypnozygotes.

\section{Methodology for studying life history of heterotrophic dinoflagellates}

Protargol silver staining of dinoflagellate life history stages allowed inspection of gross morphology (shape and size), nuclear and nucleolar morphologies, internal features like basal bodies, and the number and types of flagella (Coats et al. 1984). Flow cytometry or other means by which the intensity of fluorescently-labeled DNA is measured may be the best way for accurate estimation of DNA content and determination of phase of the cell cycle or life history stage if other characteristics cannot be seen, and has been used successfully in the study of the cell cycles of many plankton species (e.g., Chisholm et al. 1986; Cetta and Anderson 1990; Whiteley et al. 1993; Parrow and Burkholder 2002). Standard flow cytometry was generally not feasible for $P$. steidingerae, however, due to the species' large size, the difficulty in completely synchronizing the life cycle in culture, and because the heterotroph must be cultured with phytoplankton prey. Additionally, flow cytometry does not allow discrimination between haploid cells in the G2 phase of the cell cycle and diploid sexual stages like planozygotes or planomeiocytes (Cetta and Anderson 1990). While fluorescent staining of DNA would permit more rapid examination of DNA content, it does not allow simultaneous examination of other morphological features, like nucleoli, flagella, and basal bodies, which provide important 
information about life cycle stage. On the other hand, the morphological observations of protargol silver stained specimens indicated that nucleus size alone was not indicative of DNA content, and was not sufficient for determining cell cycle or life cycle stage. Planomeiocytes and cysts, the diploid products of sexual fusion with presumably twice the DNA content of haploid vegetative cells, had much smaller nuclei than did vegetative cells.

Continuous rotation of Protoperidinium cultures is standard practice for culturing these heterotrophic organisms in the laboratory (e.g., Jacobson and Anderson 1986; Buskey et al. 1994; Naustvoll 1998), but complicated our ability to make observations of the life history in $P$. steidingerae. Even individually isolated cells did not proceed to their next life stage unless rotated. Neither vegetative cells nor planomeiocytes would divide unless rotated, although the cells could survive for several days. The reason that continuous rotation is needed is not clear, however. Water movement may keep phytoplankton cells suspended, thereby assisting Protoperidinium in accessing their prey, but $P$. steidingerae was observed to feed successfully even when flasks or plates were stationary (Appendix 1 , this thesis). Constructing individual chambers for each isolated cell and rotating these chambers did allow observation of life stage transitions, but was labor intensive, reducing the total number of such observations that we were able to make.

\section{Time series experiments}

Combining the analysis of protargol-stained samples taken from a culture over time with observations of live cells allowed us to obtain greater detail about the life cycle of $P$. steidingerae than was possible by observations of live cells alone. Although once preserved and stained these specimens were static, the order of appearance of different life history stages over time and the range of nuclear and flagellar morphologies observed within each stage enabled the inference of a probable series of events and transitions between life history stages in asexual and sexual reproduction. 


\section{Life history of Protoperidinium steidingerae}

In the clonal cross time series experiment, a pulse of dividing cells preceded increases in concentrations of vegetative cells and gametes. The peak in the concentrations of both vegetative cells and gametes at $160 \mathrm{hr}$. followed the pulse in dividing cells between $16 \mathrm{hr}$. and $112 \mathrm{hr}$., which peaked at $88 \mathrm{hr}$. The results indicated that some portion of the dividing cells likely were undergoing asexual division to replicate vegetative cells, while others were differentiating to form gametes. The observation that the maximum concentration of dividing cells at $88 \mathrm{hr}$. was still relatively low compared with the resulting concentrations of vegetative cells and gametes at $112 \mathrm{hr}$. and $160 \mathrm{hr}$. was reasonable considering that division is likely a short-lived process, so that at any one time point only a portion of the total cells undergoing division during a 24 hour period was captured.

When identifying dividing cells in protargol-stained preparations, we did not distinguish between those cells undergoing typical asexual division and those undergoing gametogenesis. Dividing cells ranged in length from 81 to $135 \mu \mathrm{m}$, and it may be that the smaller of these dividing cells were undergoing a depauperate division that would result in gametes. Small division cysts were observed in live cultures, and the resulting daughter cells were presumed to be gametes, based on size.

After $160 \mathrm{hr}$, the concentrations of both vegetative cells and gametes declined precipitously. With $48 \mathrm{hr}$. between sampling points at this stage in the experiment, we may have missed additional fluctuations in concentrations after $160 \mathrm{hr}$. We might speculate that most of these vegetative cells divided to form gametes, resulting in the low concentration of vegetative cells at $208 \mathrm{hr}$. An increase in gamete concentration could have been missed in the time elapsed between the $160 \mathrm{hr}$. and $208 \mathrm{hr}$. sampling points. Gametes seemed to be short-lived stages, dying within one to two days if they had not fused to form planozygotes. Those vegetative cells remaining after $208 \mathrm{hr}$. may have 
continued to reproduce asexually, leading to the increasing concentration of vegetative cells over the last $72 \mathrm{hr}$. of the experiment.

Sampling of the cross of two clonal cultures of $P$. steidingerae was conducted in the morning, and all live observations were made during daylight hours, so we may have missed most gamete fusions. The large drop in the concentration of gametes in the clonal cross time series, and the corresponding increase in the concentration of planozygotes between the first sampling time in the afternoon and the second sampling time the next morning may indicate that $P$. steidingerae gamete fusions occur primarily at night. A higher occurrence of gamete fusion at night versus during the day has been previously reported for some photosynthetic dinoflagellate species (Pfiester and Anderson 1987).

In the clonal cross time series experiment, gametes preceded the appearance of triflagellated cells with double the number of nucleoli of vegetative cells and two pair of basal bodies, which were classified as planozygotes. Many more gametes were produced than resulted in planozygotes in the time series. Like gametes of the heterotrophic dinoflagellate Pfiesteria spp. (Parrow et al. 2002), gametes of $P$. steidingerae were never observed to feed in culture. These gametes seemed to be short lived, dying relatively quickly if they did not fuse. This hypothesis is supported by our observation that isolated gametes rarely survived more than 24 hours and never more than 3 days, even if rotated.

Several observations suggested that $P$. steidingerae cells will not divide in the absence of food. Starvation of $P$. steidingerae cultures for several days resulted in the loss of small stages like gametes and recently-divided daughter cells, leaving present only large cell types, presumably vegetative cells and planomeiocytes. Isolated $P$. steidingerae vegetative cells, on the other hand, survived for several days, even without food (K. Gribble, personal observation), and Protoperidinium spp. cultures have been shown to persist for up to several weeks in conditions of very low food concentrations (MendenDeuer et al. 2005). Isolated planomeiocyte cells that were cultured with prey and rotated 
were frequently seen to feed before division, but isolated vegetative and planomeiocyte cells of $P$. steidingerae that were not rotated did not divide. The arresting of the cell cycle in the absence of food may indicate a nutritionally-dependent cell cycle checkpoint before division as hypothesized by Parrow et al. (2002). Such a checkpoint would prevent the presumably energy-costly processes of DNA replication or mitotic division, and allow cell maintenance on available cellular food reserves.

In the clonal cross time series, dormant hypnozygotes appeared in culture only after diploid planozygotes were detected. The similarity in the number of nucleoli, double that of vegetative cells and gametes, and the presence of two pair of basal bodies and two longitudinal flagella indicated that the planozygotes and hypnozygotes were diploid products of sexual fusion.

While the proportion of planozygotes remained low throughout the time series, hypnozygote production by the end of the experiment was not high enough to account for encystment of all planozygotes within approximately three days after gamete fusion, suggesting that either not all planozygotes were viable, or not all formed hypnozygotes. This is supported by the fact that all of the 60 isolated putative planozygotes died without forming hypnozygotes. Alternatively, some planozygotes may persist longer than three days before hypnozygote formation. The reason for the low success rate of planozygote encystment is unclear but could be due to inappropriate culture conditions. On the other hand, planozygotes may be able to divide and revert to asexual reproduction without going through a hypnozygote stage, although that process was not captured by our experiments or observations. Previous studies of Gyrodinium uncatenum (Coats et al. 1984) and Alexandrium tamarense (Anderson et al. 1984), have reported similar findings of many planozygotes resulting in fewer cyst than expected. 


\section{Homothallism}

Sexual reproduction was homothallic in $P$. steidingerae, as hypnozygotes were produced in clonal cultures. Casual observations indicated, however, that hypnozygote production was higher and more rapid in non-clonal cultures or when two or more clonal cultures were mixed. Others have documented significant differences in hypnozygote production depending upon parental strains crossed (Figueroa and Bravo 2005), although in that case G. nolerii was not homothallic. A "preference" rather than a requirement for heterothallism would appear to be a useful strategy for an organism in the field, allowing for maximal genetic recombination, but not precluding self-crossing and encystment when necessary for survival. The possibility does exist that the putative clonal cultures in which we witnessed cyst production were started from a single planozygote or planomeiocyte which later divided into compatible mating types, rather than from a vegetative cell. These stages all are of similar size and shape, and we may have missed the presence of two longitudinal flagella when isolating a live, swimming cell.

\section{Nuclear cyclosis}

Meiosis in dinoflagellates is poorly characterized, but is believed to be associated with the process of nuclear cyclosis, a slow swirling of the nuclear contents often succeeded by cell division (von Stoch 1972). Nuclear cyclosis has been documented in different sexual life history stages in a small number of autotrophic and heterotrophic dinoflagellates, occurring in the planozygote, zygotic division cyst, hypnozygote, or planomeiocyte (for reviews, see Pfiester and Anderson 1987; Parrow and Burkholder 2004).

In $P$. steidingerae, nuclear cyclosis appears to occur in the planomeiocyte, just before the first division. Only one protargol-stained planomeiocyte was observed to support this hypothesis, and no observations of nuclear cyclosis were made in live cells, so this premise should be considered preliminary until further evidence is available. The nuclear morphology in the protargol-stained specimen was consistent with the morphology 
described for the "Knäuel" stage in Ceratium species undergoing meiosis (von Stoch 1972). Like protargol-stained specimens of Gyrodinium uncatenum in the process of meiosis, the specimen of $P$. steidingerae had an enlarged nucleus with grainy, stained chromosomes and a single large nucleolus (Coats et al. 1984). Nuclear cyclosis had been previously observed in a live planozygote of Protoperidinium depressum (Bailey) Balech (Appendix 2, this thesis). In $P$. depressum, protargol-stained specimens were observed that had two trailing flagella and contained a greatly enlarged nucleus stretched across the width of the cell with grainy staining of the chromosomes, and a single, large, round nucleolus in the center of the nucleus. In such specimens, the nucleus was oriented perpendicular to the longitudinal axis of the cell, unlike the obliquely oriented nucleus of a dividing cell (Gribble, Appendix 2). The similarity of the stained nucleus in the $P$. steidingerae planomeiocyte 72 days after germination to $P$. depressum specimens undergoing meiosis supports the preliminary finding that nuclear cyclosis may occur in the planomeiocyte stage in $P$. steidingerae.

\section{Species identification}

Given that all species descriptions for Protoperidinium spp. have been made from field specimens, it is possible that morphologically-distinct life cycle stages have been classified as separate species, as was the case with the small male gametes of Ceratium spp. Schrank which had been assigned to the subgenus Tripoceratium before the sexual cycle of Ceratium was understood (von Stoch 1964; von Stoch 1973).

Vegetative cells of $P$. steidingerae may be easily confused with Protoperidinium oblongum (Aurivillius) Parke and Dodge and Protoperidinium oceanicum (Vanhoffen) Balech if thecal plate morphology is not examined. Similarly, the cysts of $P$. steidingerae, like the vegetative cells, may be easily confused with those of $P$. oblongum. In fact, the original description of the P. oblongum cyst (Wall and Dale 1968) may actually have been a description of the cyst of $P$. steidingerae. The cysts in the original description were isolated from sediments in Woods Hole, MA, the same region where we 
collected $P$. steidingerae from the surface waters. The cysts described in the previous work had the same morphology and archeopyle type as those produced in our cultures. The cells that germinated from those cysts were called $P$. oblongum var. latidorsale, and although Wall and Dale did not fully describe the thecal plate structure, their specimens did have a single intercalary plate like the species later named $P$. steidingerae (Balech 1979 ) instead of the three intercalary plates of $P$. oblongum (Dodge 1982). Recent molecular phylogenetic work on $P$. oblongum and $P$. steidingerae establishes that they are indeed separate species (Gribble and Anderson In press). Protoperidinium oblongum may have a very similar cyst to that of $P$. steidingerae, but the morphology of the $P$. oblongum cyst should be confirmed and extra care must be taken in field studies to discriminate both the cells and cysts of these two species.

The species studied here was also likely the same as the two Protoperidinium species, Protoperidinium novella sp. nov. and Protoperidinium conicinna sp. nov., recently established and placed into a new subgenus, Testeria, by Maria Faust (2006). The SEM images presented for these two species showed the same thecal plate morphology as that of $P$. steidingerae, with a single, six-sided intercalary plate and a four-sided ventral apical plate that did not meet the top of the epitheca, so that the 2' and 4' plates touched on the ventral side of the cell. Protoperidinium novella and P. conicinna were separated from one another based only on cell size, ranging from 98-116 $\mu \mathrm{m}$ long by 62-75 $\mu \mathrm{m}$ wide and 103-137 $\mu \mathrm{m}$ long by 52-67 $\mu \mathrm{m}$ wide, respectively (Faust 2006). These cell sizes are easily encompassed in the range of sizes of the different life history stages investigated in this study. The vegetative cells alone in a clonal culture of $P$. steidingerae ranged in length from $78 \mu \mathrm{m}$ to $125 \mu \mathrm{m}$ long and 45 to $82 \mu \mathrm{m}$ wide. Such confusion is indicative of the difficulty in identifying dinoflagellate species, which often have complex life cycles with morphologically distinct stages, exclusively from field samples. Establishing cultures and/or combining molecular techniques with morphological analysis whenever possible may aid in accurate species identification. 


\section{CONCLUSIONS}

This study reveals for the first time the details of asexual and sexual reproduction in a species of Protoperidinium. Many aspects of the life history of $P$. steidingerae remain

uncharacterized, however. In particular, the triggers for sexuality and the process of gametogenesis are unknown for this species. Understanding the environmental cues leading to the sexual cycle and encystment will help to predict the dynamics of this species in the plankton. The life histories of additional species of Protoperidinium should be examined to determine how well conserved the characteristics of the life cycle are among members of this diverse genus.

\section{ACKNOWLEDGEMENTS}

Thank you to Captain Kenneth Houtler for sample collection. Thanks to Malte Elbrächter for assistance with species identification. Matthew Parrow provided helpful suggestions for creating chambers for single cell culture using 96 well plates. Thank you to Rebecca Gast and Sonya Dyhrman for microscope and camera use. The Comer Foundation and the Woods Hole Oceanographic Institution Biology Department Education Fund provided funding for this project.

\section{REFERENCES}

Anderson, D. M. 1998. Physiology and bloom dynamics of toxic Alexandrium species, with emphasis on life cycle transitions, p. 29-48. In D. M. Anderson, A. D. Cembella and G. M. Hallegraeff [eds.], Physiological Ecology of Harmful Algal Blooms. NATO ASI Series. Springer-Verlag.

Anderson, D. M., D. M. Kulis, and B. J. Binder. 1984. Sexuality and cyst formation in the dinoflagellate Gonyaulax tamarensis: Cyst yield in batch cultures. Journal of Phycology 20: 418-425.

Anderson, D. M., and K. RenGefors. 2006. Community assembly and seasonal succession of marine dinoflagellates in a temperate estuary: The importance of life cycle events. Limnology and Oceanography 51: 860-873. 
ANDERSON, D. M., and D. WALL. 1978. Potential importance of benthic cysts of Gonyaulax tamarensis and G. excavata in initiating toxic dinoflagellate blooms. Journal of Phycology 14: 224-234.

BALECH, E. 1974. El genero Protoperidinium Bergh, 1881 (Peridinium Ehrenberg, 1831, Partim). Revista del Museo Argentino de Ciencias Naturales "Bernardino Rivadavia" e Instituto Nacional de Investigacion de las Ciencias Naturales 4: 179.

---. 1979. Tres Dinoflagelados nuevos o interesantes de aguas Basileñas. Bolm Inst. Oceanogr., S. Paulo 28: 55-64.

BUSKEY, E. J., C. J. CoulteR, and S. L. BROWN. 1994. Feeding, growth and bioluminescence of the heterotrophic dinoflagellate Protoperidinium huberi. Marine Biology 121: 373-380.

CetTA, C. M., and D. M. Anderson. 1990. Cell cycle studies of the dinoflagellates Gonyaulax polyedra Stein and Gyrodinium uncatenum Hulburt during asexual and sexual reproduction. Journal of Experimental Marine Biology and Ecology 135: 69-84.

Chisholm, S. W., E. V. Armbrust, and R. J. Olson. 1986. The individual cell in phytoplankton ecology: cell cycles and application of flow cytometry, p. 343-369. In T. Platt and W. K. W. Li [eds.], Photosynthetic Picoplankton. Can. Bull. Fish. Aquat. Sci.

COATS, D. W., and J. F. HeINBOKEL. 1982. A study of reproduction and other life cycle phenomena in planktonic protists using an acridine orange fluorescence technique. Marine Biology 67: 71-79.

CoATS, D. W., M. A. TYLeR, and D. M. ANDERSON. 1984. Sexual processes in the life cycle of Gyrodinium uncatenum (Dinophyceae): A morphogenic overview. Journal of Phycology 20: 351-361.

Daugbjerg, N., G. Hansen, J. Larsen, and Ø. Moestrup. 2000. Phylogeny of some of the major genera of dinoflagellates based on ultrastructure and partial LSU rDNA sequence data, including the erection of three new genera of unarmoured dinoflagellates. Phycologia 39: 302-317.

DodGE, J. D. 1982. Marine Dinoflagellates of the British Isles. Her Majesty's Stationery Office. 
Faust, M. A. 2006. Creation of the subgenus Testeria Faust subgen. nov. Protoperidinium Bergh from the SW Atlantic Ocean: Protoperidinium novella sp. nov. and Protoperidinium conicinna sp. nov. Dinophyceae. Phycologia 45: 19.

FigueroA, R. I., and I. Bravo. 2005. A study of the sexual reproduction and determination of mating type of Gymnodinium nolleri (Dinophyceae) in culture. Journal of Phycology 41: 74-83.

GAINES, G., and F. J. R. TAYLOR. 1984. Extracellular digestion in marine dinoflagellates. Journal of Plankton Research 6: 1057-1062.

GRIBBLE, K. E., and D. M. ANDERSON. In press. Molecular phylogeny of the heterotrophic dinoflagellates, Protoperidinium, Diplopsalis, and Preperidinium (Dinophyceae), inferred from LSU ribosomal DNA. Journal of Phycology.

GUILLARD, R. R. L. 1975. Culture of phytoplankton for feeding marine invertebrates. In W. L. Smith and M. H. Chanley [eds.], Culture of Marine Invertebrates. Plenum Publishing Corporation.

JACOBSON, D. M., and D. M. ANDERSON. 1986. Thecate heterotrophic dinoflagellates: Feeding behavior and mechanisms. Journal of Phycology 22: 249-258.

JEONG, H. J. 1996. The predation impact by the heterotrophic dinoflagellate Protoperidinium cf. divergens on copepod eggs in the presence of co-occurring phytoplankton prey. Journal of the Oceanological Society of Korea. Seoul 31: 144-149.

Menden-Deuer, S., E. J. Lessard, J. SATterberg, and D. Grünbaum. 2005. Growth rates and starvation survival of three species of the pallium-feeding, thecate dinoflagellate genus Protoperidinium. Aquatic Microbial Ecology 41: 145-152.

Montagnes, D. J. S., and D. H. LYNN. 1993. A Quantitative Protargol Stain (QPS) for ciliates and other protists, p. 229-240. In P. F. Kemp, B. F. Sherr, E. B. Sherr and J. B. Cole [eds.], Handbook of Methods in Aquatic Microbial Ecology. Lewis Publishers, CRC Press, Inc.

NAUSTVOLL, L. J. 1998. Growth and grazing by the thecate heterotrophic dinoflagellate Diplopsalis lenticula (Diplopsalidaceae, Dinophyceae). Phycologia 37: 1-9. 
---. 2000. Prey size spectra and food preferences in thecate heterotrophic dinoflagellates. Phycologia 39: 187-198.

PARROW, M. W., and J. M. BURKHOLDER. 2002. Flow cytometric determination of zoospore DNA content and population DNA distribution in cultured Pfiesteria spp. (Pyrrhophyta). Journal of Experimental Marine Biology and Ecology 267: $35-51$.

---. 2004. The sexual life cycles of Pfiesteria piscicida and cryptoperidiniopsoids (Dinophyceae). Journal of Phycology 40: 664-673.

Parrow, M. W., J. M. Burkholder, N. J. Deamer, and C. Zhang. 2002. Vegetative and sexual reproduction in Pfiesteria spp. (Dinophyceae) cultured with algae prey, and inferences for their classification. Harmful Algae 1: 5-33.

PfIESTER, L. A., and D. M. ANDERSON. 1987. Dinoflagellate reproduction, p. 611-648. In F. J. R. Taylor [ed.], The Biology of Dinoflagellates. Botanical Monographs. Blackwell Scientific Publications.

Scholin, C. A., M. Herzog, M. Sogin, and D. M. Anderson. 1994. Identification of group- and strain-specific genetic markers for globally distributed Alexandrium (Dinophyceae). II. Sequence analysis of a fragment of the LSU rRNA gene. Journal of Phycology 30: 999-1011.

VON STOCH, H. A. 1964. Zum problem der sexuellen fortpflanzung in der Peridineengattung Ceratium. Helgoländer wissenschaftliche Meeresuntersuchungen 10: 140-151.

---. 1972. La signification cytologique de la "cyclose nucléaire" dans le cycle de vie des Dinoflagellés. Soc. bot. Fr., Mémoires: 201-212.

---. 1973. Observations on vegetative reproduction and sexual life cycles of two freshwater dinoflagellates, Gymnodinium pseudopalustre Schiller and Woloszynskia apiculata sp. nov. Br. Phycol. J. 8: 105-134.

WALL, D., and B. DALE. 1968. Modern dinoflagellate cysts and evolution of the Peridiniales. Micropaleontology 14: 265-304.

Whiteley, A. S., P. H. BuRKILl, and M. A. Sleigh. 1993. Rapid method for cell cycle analysis in a predatory marine dinoflagellate. Cytometry 31: 100-109. 


\title{
Chapter 4
}

Molecular phylogeny of the heterotrophic dinoflagellates, Protoperidinium, Diplopsalis, and Preperidinium (Dinophyceae), inferred from LSU rDNA $^{1}$

\author{
Kristin E. Gribble and Donald M. Anderson
}

Woods Hole Oceanographic Institution, Biology Department, MS 32,

Woods Hole, MA 02543 USA

\footnotetext{
${ }^{1}$ In press, Journal of Phycology
} 


\begin{abstract}
The genera Protoperidinium Bergh, Diplopsalis Bergh, and Preperidinium Mangin, comprised of species of marine, thecate, heterotrophic dinoflagellates in the Family Protoperidinaceae Balech, have had a confused taxonomic history. To elucidate the validity of morphological groupings within the Protoperidinium and diplopsalids, and determine the evolutionary relationships between these and other dinoflagellates, we undertook a study of molecular phylogeny using the D1-D3 domains of the large subunit of the ribosomal DNA (LSU rDNA). Based on morphology, the 10 Protoperidinium species examined belonged to three subgenera and five morphological sections. Two diplopsalid species were also included. Single-cell PCR, cloning, and sequencing revealed a high degree of intraindividual sequence variability in the LSU rDNA. The genus Protoperidinium appeared to be recently divergent in all phylogenetic analyses. In maximum parsimony and neighbor joining analyses, Protoperidinium formed a monophyletic group, evolving from diplopsalid dinoflagellates. In maximum likelihood and Bayesian analyses, however, Protoperidinium was polyphyletic, as the lenticular, diplopsalid heterotroph, Diplopsalis lenticula Bergh, was inserted within the Protoperidinium clade as basal to Protoperidinium excentricum (Paulsen) Balech, and Preperidinium meunieri (Pavillard) Elbrächter fell within a separate clade as a sister to the Oceanica and Protoperidinium steidingerae Balech. In all analyses, the Protoperidinium were divided into two major clades, with members in the Oceanica group and subgenus Testeria in one clade, and the Excentrica, Conica, Pellucida, Pyriforme and Divergens sections in the other clade. The LSU rDNA molecular phylogeny supported the historical morphologically-determined sections, but not a simple morphology-based model of evolution based on thecal plate shape.
\end{abstract}

Key index words: heterotrophic dinoflagellate; molecular phylogeny; LSU rDNA; single-cell PCR; Protoperidinium; Preperidinium; Diplopsalis; SEM; taxonomy 
Abbreviations: maximum likelihood, ML; maximum parsimony, MP; neighbor-joining, $\mathrm{NJ}$; polymerase chain reaction, PCR; ribosomal deoxyribonucleic acid, rDNA; scanning electron microscopy, SEM

\section{INTRODUCTION}

The genera Protoperidinium Bergh, Diplopsalis Bergh, and Preperidinium Mangin are comprised of species of marine, thecate, heterotrophic dinoflagellates in the Family Protoperidinaceae Balech. As raptorial, often selective feeders on species of large phytoplankton, including diatoms, dinoflagellates (Jacobson and Anderson 1986; Naustvoll 2000), and even zooplankton eggs (Jeong 1996), these heterotrophs play an important, but poorly defined, role in planktonic trophic dynamics. These genera have had a confused taxonomic history, and until recently, no genetic information has been available to inform species identification or to resolve their evolutionary relationships with one another or with the other dinoflagellates.

Protoperidinium is a cosmopolitan genus of more than 200 morphologically-defined species (Balech 1974). As summarized here from comprehensive historical reviews by Taylor (1976), Abé (1981), Dodge (1982), and references therein, the genus has a long and complex taxonomic history. The genus Peridinium Ehrenberg was established by Ehrenberg in 1830, and originally included not only species now in the Protoperidinium but also those in Gymnodinium Stein and Ceratium Schrank. Bergh erected the new genus Protoperidinium in 1881, including in it species with distinct sulcal lists, but leaving in the Peridinium species with antapical horns or without sulcal lists (Bergh 1881). Over the next few decades, many other workers divided the Peridinium into subgroups based largely on cell shape and girdle configuration until, in 1909, Kofoid provided the detailed thecal morphological descriptions upon which the current thecal classification is based (Kofoid 1909). 
In 1912, Jörgensen proposed a system of subdivision of the Peridinium based upon the combinations of the thecal plate patterns of the ventral and dorsal epitheca (Jörgensen 1912). Species with two epithecal intercalary plates were placed in a new genus, Archaeperidinium, while Peridinium retained species with three intercalary plates. Based upon the shape of the first apical (1') plate, two subgenera were erected, Orthoperidinium including species with ortho (four-sided) 1' plates and Metaperidinium including meta (five-sided) and para (six-sided) plates. Combined with the three shapes defined for the second intercalary plate, quadra (four-sided), penta (five sided), and hexa (six-sided), the Orthoperidinium was divided into three sections, and Metaperidinium into four sections. Jörgensen's system was generally accepted, with a few revisions. The Paraperidinium (six-sided 1') was eventually made a separate group, divided into three sections, and the Metaperidinium was broken into two sections as shown in Table 1. Paulsen (1931) followed Lebour's (1922) proposal that Archaeperidinium was a subgenus, but divided it into two sections: Avellana and Excentrica, with symmetrical or asymmetrical epithecae, respectively. Recently, Faust (2006) erected the subgenus Testeria for Protoperidinium with no apical pore and a single intercalary plate (Table 2).

Balech (1974) resurrected Bergh's genus, Protoperidinium, thereby separating marine, heterotrophic species with three cingular plates and a transitional plate from the Peridinium, phototrophic, freshwater species with five or six cingular plates plus a transitional plate. The characteristic plate formula of Protoperidinium is 4', 3a, 7', 3c, 5 "', 2" ", though there are a few species with one, two, or four intercalary plates. An apical platelet surrounds the apical pore. The canal plate connects the apical pore and the first apical plate, a feature missing in some Peridinium species and in all Gonyalacoideae. A transition plate sits between the cingulum and sulcus, and the sulcus has six or seven plates. Balech and Abé greatly emphasized the structure of the sulcal plates in species identification. Given the difficulty in seeing these plates using transmitted light microscopy, and the frequent obscuring of the plates by pronounced sulcal lists, even 
when employing scanning electron microscopy (SEM), these small plates have not been routinely used for identification.

The Subfamily Diplopsaloideae Abé is composed of lenticular or globular thecate dinoflagellates. The cingulum in these species is equatorial, usually with prominent lists. A pronounced list usually outlines the left side of the sulcus. The large antapical flagellar pore is situated more medially in the diplopsalids than in the Protoperidinium and is difficult to observe due to the lists of the sulcal plates. Like the Protoperidinium, members of the Diplopsalis group have three cingular plates, but may have only one or two antapical plates, and have only one or two anterior intercalaries.

As with the Protoperidinium, the taxonomy of the Diplopsalis group has been greatly confused (see Taylor 1976; Abé 1981; Dodge 1982 for full historical reviews). R.S. Bergh first established the genus Diplopsalis with his description of D. lenticula (Bergh 1881), but Stein was the first to provide plate tabulation for the species, although his illustration of $D$. lenticula seems to have included more than one species (as discussed in Dodge 1982).

Around the same time, Pouchet identified a lenticular species with an ascending and overhanging girdle as Glenodinium lenticula, but which likely belonged to the Globula group within the Protoperidinium (Pouchet 1883). Glenodinium Ehrenberg remained poorly defined, and species designated to this genus have largely been redefined over the years. Over the succeeding decades, there were several other descriptions of $D$. lenticula and of new species, variously placed into the Diplopsalis Meunier, Peridinium, Glenodinium, Diplopsalopsis, Peridiniopsis Lemmermann, Zygabikodinium Loeblich and Loeblich III, and Preperidinium, many of which were incompletely figured. The difficulty of the taxonomic history of the group is illustrated by the placement of approximately 20 species variously into 11 different genera (Dodge and Hermes 1981). 


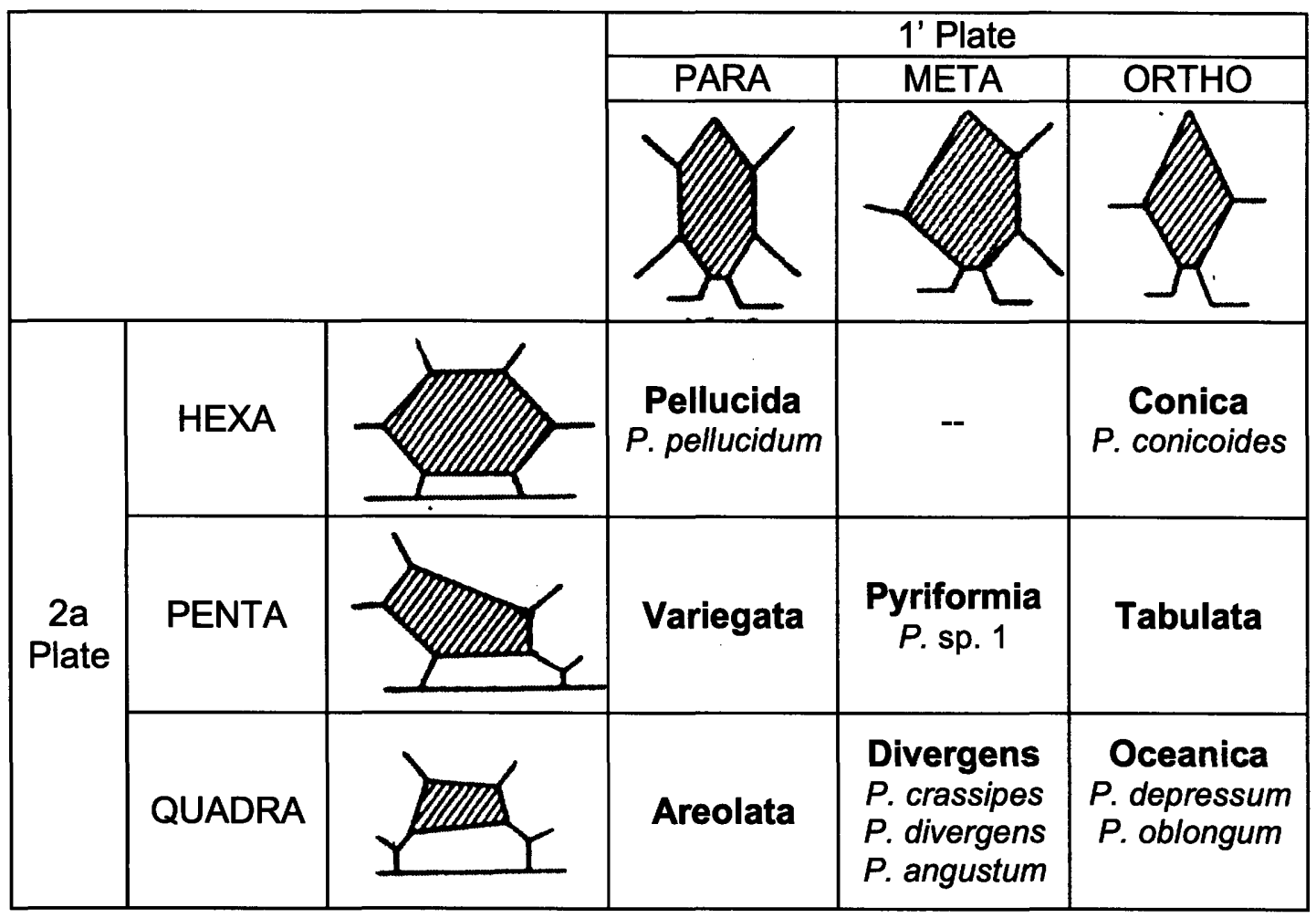

Table 1.

Morphological sections of Protoperidinium as defined by Jörgensen (1912), based on structure of 1' and 2a thecal plates. Species included in this study within each group are listed. Figure after Nicolaus Peters (1928). 


\begin{tabular}{|c|c|}
\hline & VENTRAL \\
\hline $\begin{array}{c}\text { ARCHAEPERIDINIUM } \\
\text { EXCENTRICA } \\
\text { P. excentricum }\end{array}$ \\
\hline steidingerae
\end{tabular}

\section{Table 2.}

Ventral and dorsal epithecal plate morphologies of Protoperidinium species with one or two intercalary plates that were included in this study. Illustrations of P. steidingerae from Balech (1979) and of P. excentricum from Dodge (1982). 
The Subfamily Diplopsaloideae Abé now falls within the Family Protoperidinaceae, and includes nine genera of extant, marine heterotrophs (Fensome et al. 1993), after Zygabikodinium lenticulatum Loeblich and Loeblich III was restored to its original species description as Preperidinium meunieri (Pavillard) Elbrächter (Elbrächter 1993). The group has been considered ancestral to modern Protoperidinium based, in part, on cyst morphology (Matsuoka 1988).

Despite the more than two hundred recorded species of Protoperidinium and the long history of investigation of both the Protoperidinium and the Diplopsaloideae, there remains a great deal of taxonomic uncertainty. The majority of species have been insufficiently figured and described. All species identifications have been from field samples, raising the distinct possibility that geographically separated strains of the same species may have been re-identified as separate species by different workers. Additionally, morphologically distinct life cycle stages may have been classified as separate species, as was the case with the small male gametes of Ceratium spp. which had been assigned to the subgenus Tripoceratium before the sexual cycle of Ceratium was understood (von Stoch 1964; von Stoch 1973). The matching of morphology with molecular markers may thus provide more robust means for defining species.

Until recently, there has been a complete lack of information about the molecular phylogeny of these thecate heterotrophic dinoflagellates. Within the last few years, however, 11 Protoperidinium species have been added to dinoflagellate phylogenies based on SSU rDNA sequences (Saldarriaga et al. 2004; Yamaguchi and Horiguchi 2005). We do not yet have representatives from all major taxonomic groupings, nor any DNA sequence information about the presumably closely related diplopsalids of the genera Diplopsalis or Preperidinium.

To begin to remedy this taxonomic confusion, better elucidate the validity of morphological groupings within the Protoperidinium and diplopsalids, and determine the 
evolutionary relationships between these thecate heterotrophs and other dinoflagellates, we undertook a study of the molecular phylogeny of these heterotrophic dinoflagellates using the large subunit of the ribosomal DNA (LSU rDNA). The LSU rDNA, having both highly conserved and highly variable regions, allows comparison across a range of taxonomic levels, from within species to between genera and families. Previous phylogenetic studies using the LSU rDNA provided sequences from other dinoflagellate species with which the sequences of Protoperidinium and diplopsalid species from this study could be compared (e.g., Daugbjerg et al. 2000; Hansen et al. 2000; Ellegaard et al. 2003; Hansen et al. 2003).

In this study, we sequenced the partial LSU rDNA of 10 species of Protoperidinium from two subgenera, encompassing five described morphological sections and one undescribed section (Tables 1 and 2), and two species of lenticular heterotrophic genera, Diplopsalis lenticula Bergh and Preperidinium meunieri, and used these sequences to infer the phylogeny of the group. The molecular phylogeny was compared with the morphological groupings of these heterotrophic species.

\section{MATERIALS AND METHODS}

\section{Culturing}

Protoperidinium spp. were isolated from a variety of locations and grown in $0.2 \mu \mathrm{m}$ filtered, Teflon-autoclaved seawater from Vineyard Sound (30 psu, or amended to $35 \mathrm{psu}$ by evaporation) and appropriate phytoplankton food species (Table 3). Cultures were contained in $70 \mathrm{~mL}$ untreated tissue culture flasks (Falcon 353009, Becton Dickinson, Franklin Lakes, NJ) and rotated on a plankton wheel at $1-2 \mathrm{rpm}$ at $15^{\circ} \mathrm{C}$ under low light

(ca. $50 \cdot \mu \mathrm{mol} \cdot \mathrm{m}^{-2} \cdot \mathrm{sec}^{-1}$ ) on a $14 \mathrm{~h}: 10 \mathrm{~h}$ light:dark cycle. Cultures were transferred every 4 to 5 days by pouring approximately two-thirds the volume of the old culture into a new flask containing fresh sterile seawater and phytoplankton prey. 
Table 3.

Culture designation, type, origin, food species, and GenBank accession number for LSU rDNA sequence of thecate, heterotrophic dinoflagellates species studied. Lp = Lingulodinium polyedrum, $\mathrm{Db}=$ Ditylum brightwellii (West) Grunow, and $\mathrm{Ca}=$ Chaetocerous affinis Lauder. 


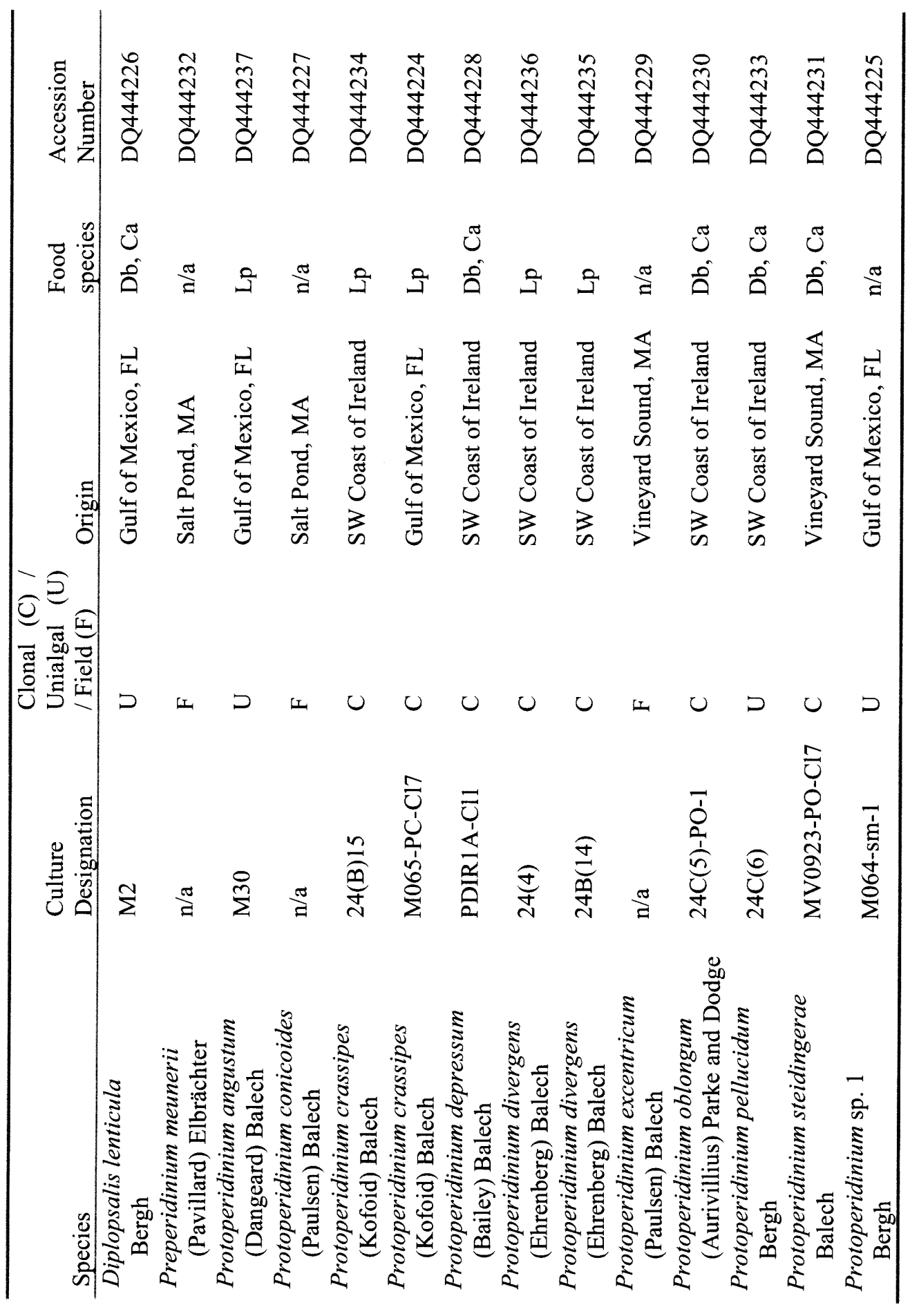


Dinoflagellate cultures used as food for the heterotrophic dinoflagellates were maintained at $15^{\circ} \mathrm{C}$ or $20^{\circ} \mathrm{C}$ in tubes with $25 \mathrm{~mL}$ of $\mathrm{f} / 2$ nutrient medium minus silicate (Guillard 1975), except for Lingulodinium polyedrum (Stein) Dodge which was grown in ES medium (Kokinos and Anderson 1995). Diatom cultures were maintained in tubes with $25 \mathrm{~mL}$ of $\mathrm{f} / 2$ nutrient medium plus silicate at $15^{\circ} \mathrm{C}$. All prey cultures were kept at a photon flux density of ca. $100 \mu \mathrm{mol} \cdot \mathrm{m}^{-2} \cdot \mathrm{s}^{-1}$, on a $14 \mathrm{~h}: 10 \mathrm{~h}$ light:dark cycle.

\section{SEM}

Morphological species identification was confirmed by examination of thecal plate structure using SEM. Samples were preserved with borate-buffered formalin (5\% final concentration) and stored at $4^{\circ} \mathrm{C}$ at least overnight. Subsamples were centrifuged, aspirated to $1 \mathrm{~mL}$, and brought up to $4 \mathrm{~mL}$ with filtered seawater. Several hundred Protoperidinium cells were isolated by micropipette from phytoplankton prey in the sample, and were deposited into $2 \mathrm{ml}$ cryovials with $5 \%$ formalin in filtered seawater and stored at $4^{\circ} \mathrm{C}$ overnight. Samples were drawn down onto filters (Nucleopore tracketched membrane, $13 \mathrm{~mm}, 5 \mu \mathrm{m}$ pore size), and washed with filtered sea water and then with distilled, deionized water to remove fixatives and salts. Samples were dehydrated in a series of ethanol washes of increasing concentration, critical point dried (Tousimis Samdri-780A), sputter coasted with gold palladium (Tousimis Samsputter-28), and examined on a scanning electron microscope (JEOL JSM-840).

\section{Calcofluor White}

As an alternative to SEM, thecal plates were examined by staining with Calcofluor White (Fritz and Triemer 1985). Cultures and field samples were preserved with formalin (5\% final concentration) and stored at $4^{\circ} \mathrm{C}$ until analysis. Samples were centrifuged, aspirated to a pellet, resuspended in $1 \mathrm{~mL} \mathrm{FSW}$ and $5 \mu \mathrm{L}$ of a $1.0 \mathrm{mg} \mathrm{mL}^{-1}$ solution of Calcofluor White MR2 (Polysciences, Warrington, PA), which stains cellulose thecal plates. After staining for 10 minutes, each sample was aspirated to a pellet and then resuspended in 2 to $10 \mathrm{~mL}$ of FSW for analysis. Subsamples of up to $1 \mathrm{~mL}$ were 
examined at $100-200 \mathrm{X}$ on a Zeiss Axioskop microscope with a $100 \mathrm{~W}$ mercury lamp and a Zeiss \#2 filter set (excitation $365 \mathrm{~nm}$, emission $420 \mathrm{~nm}$ ). Images were taken with a Zeiss MC 100 digital camera system. Species identifications were as in Abé (1981), Dodge (1982), and Elbrächter (1993).

\section{Single-cell PCR amplification, cloning, and sequencing}

Single-cell PCR was used to amplify the target sequence. Single dinoflagellate cells were isolated from culture or field samples by micropipette. Each cell was washed 2-3 times in sterile filtered seawater and 1-2 times in sterile DI water before being deposited individually into a PCR tube in approximately $10 \mu \mathrm{L}$ of sterile DI water. PCR tubes with isolated cells were frozen at $-80^{\circ} \mathrm{C}$ overnight to enhance cell lysis. To further improve lysis, isolated cells in PCR tubes, immersed in an ice bath, were subjected to a sonification bath at $40 \mathrm{~A}$ for approximately $30 \mathrm{sec}$ immediately before PCR.

The single cells were used directly as template to amplify approximately $1430 \mathrm{bp}$ of the LSU rDNA containing the variable domains D1-D6, using the primers D1R (Scholin et al. 1994) and 28-1483R (Daugbjerg et al. 2000). The $50 \mu \mathrm{L}$ PCR reaction mixture contained 2.5 units $P f u$, a proofreading DNA polymerase (Stratagene, La Jolla, CA), 5 $\mu \mathrm{L} 10 \mathrm{X}$ buffer ( $1 \mathrm{x}$ final concentration), $0.3 \mu \mathrm{M}$ of each primer, and $200 \mu \mathrm{M}$ dNTPs (Takara, Shiga, Japan). Thermal cycling was conducted using an initial denaturation at $95^{\circ} \mathrm{C}$ for $5 \mathrm{~min}$., $30 \mathrm{cycles}$ of $95^{\circ} \mathrm{C}$ for $1 \mathrm{~min}$., $50^{\circ} \mathrm{C}$ for one min., and $72^{\circ} \mathrm{C}$ for $2 \mathrm{~min}$., followed by a final elongation step of $72^{\circ} \mathrm{C}$ for $10 \mathrm{~min}$.

Between 25-30 $\mu \mathrm{L}$ of PCR product was run on a 1\% agarose gel. Positive bands were excised and the product purified and concentrated using a MinElute Gel Extraction Kit (Quiagen, Valencia, CA). For each species, from 1 to 8 purified PCR products were cloned separately using the Zero Blunt TOPO PCR Cloning Kit for Sequencing (Invitrogen, Carlsbad, CA). Primers T3, T7, and an appropriate internal primer (Table 4) 


\begin{tabular}{lll}
\hline Primer & Sequence & Source \\
\hline D1R & ACCCGCTGAATTTAAGCATA & 1 \\
D2C & CCTTGGTCCCGTGTTTCAAGA & 1 \\
D3B & TCGGAGGGAACCAGCTACTA & 2 \\
D3BPR & TCGGAGGTAACCAGCTACCA & 3 \\
D3SP & AGGTAAAGCGAATGATTAG & 3 \\
D3PE & CTTTGGAGAGAACCAGCTACT & 3 \\
M064SMD3 & TCATTTGCTTTACCTGATGAAA & 3 \\
28-1483R & GCTACTACCACCAAGATCTGC & 4 \\
T3 & ATTAACCCTCACTAAAGGGA & 5 \\
T7 & TAATACGACTCACTATAGGG & 5 \\
\hline
\end{tabular}

1. Scholin et al. 1994

2. Nunn et al. 1996

3. This study

4. Daugbjerg et al. 2000

5. Invitrogen Zero Blunt TOPO PCR Cloning Kit for Sequencing

Table 4.

Primers used for PCR and sequencing of Protoperidinium, Diplopsalis, and Preperidinium spp. 


\begin{tabular}{|c|c|}
\hline Species & $\begin{array}{l}\text { Accession } \\
\text { Number }\end{array}$ \\
\hline Akashiwo sanguinea (Hirasaka) G. Hansen and Moestrup & AF260397 \\
\hline Alexandrium margalefii Balech & AY154958 \\
\hline Alexandrium pseudogonyaulax (Biecheler) Horiguchi ex Kita and Fukuyo & AY 154957 \\
\hline Amphidinium carterae Hulburt & AY455669 \\
\hline Amphidinium semilunatum Herdman & AY455678 \\
\hline Amphidinium steinii Lemmermann & AY455673 \\
\hline Ceratium lineatum (Ehrenberg) Cleve & AF260391 \\
\hline Euplotes aediculatus Pierson & AF223571 \\
\hline Fragilidium sublglobosum (von Stoch) Loeblich III & AF260387 \\
\hline Gonyaulax baltica Ellegaard, Lewis and Harding & AY144962 \\
\hline Gonyaulax cf. spinifera Diesing & AY154960 \\
\hline Gymnodinium pellucidum (Herdman) Jørgensen and Murray & AY455681 \\
\hline Heterocapsa sp. Stein & AF260399 \\
\hline Heterocapsa triquetra (Ehrenberg) F. Stein & AF260401 \\
\hline Karenia brevis (Davis) G. Hansen and Moestrup & AF200677 \\
\hline Peridinium cinctum Ehrenberg & AF260385 \\
\hline Peridinium palatinum Lauterbom & AF260394 \\
\hline Peridinium willei Huitfeld-Kaas & AF260384 \\
\hline Polarella glacialis Montresor, Procaccini and Stoecker & AY036081 \\
\hline Pyrodinium bahemense var. compressum (Böhm) Steidinger, Tester and Taylor & AY154959 \\
\hline Symbiodinium sp. Freudenthal & AJ291512 \\
\hline Tetrahymena thermophila Furgason & X54512 \\
\hline Toxoplasma gondii Nicolle and Manceaux & X75429 \\
\hline Woloszynskia pseudopalustris (Woloszynska) Kisselew & AF260402 \\
\hline
\end{tabular}

Table 5 .

GenBank accession numbers of LSU rDNA sequences for dinoflagellate, ciliate, and apicomplexan species examined in this study. 
were used for sequencing between 12 and 96 clones for each species. Sequencing was done on an Applied Biosystems 3730XL capillary sequencer.

\section{Phylogenetic analyses}

Partial LSU rDNA sequences from Protoperidinium spp., Diplopsalis lenticula, and Preperidinium meunieri were edited using Sequencher 4.5. Using ClustalX, these sequences were aligned with sequences from GenBank of 21 other dinoflagellate species and of two ciliates and one apicomplexan as an outgroup (Table 5). Only the D1-D3 domains of the LSU rDNA were available for most dinoflagellates species in GenBank, so we included only these regions in alignments and analyses. Alignments produced by ClustalX were edited manually. Bases 427-737 were too divergent for accurate alignment and were excluded from phylogenetic analyses, leaving a total of 775 bases.

The alignment was subjected to neighbor joining (NJ), maximum parsimony (MP), and maximum likelihood (ML) analyses using PAUP* 4.0b10 (Swofford 2002) and to Bayesian analysis using Mr. Bayes 3.1.1 (Ronquist and Huelsenbeck 2003). For NJ, ML, and Bayesian analysis, the parameters of the most appropriate model of DNA substitution were determined using Modeltest 3.06 (Posada and Crandall 1998). A general time reversible model $(\mathrm{GTR}+\mathrm{I}+\mathrm{G})$ with four rate categories, a proportion of invariable sites of 0.1324 , and a gamma distribution of 0.9597 best fit the data. In all analyses, gaps were treated as missing data. Phylogenetic trees calculated by MP and ML (ML using the GTR $+\mathrm{I}+\mathrm{G}$ model described above) were determined with starting trees obtained by stepwise addition and a heuristic search with 10 replicates using random addition of sequences. Branch swapping was by tree-bisection-reconnection. Bootstrap values were determined for neighbor joining (1000 reps), maximum parsimony (1000 reps) and maximum likelihood (100 reps). Bayesian analysis was run for $1,000,000$ generations with 4 chains, beginning from a random starting tree. A GTR $+\mathrm{I}+\mathrm{G}$ model was used in Bayesian analysis, with the proportion of invariable sites estimated from the data and 4 rate categories to approximate the gamma distribution. 


\section{RESULTS}

\section{Morphological analyses}

Based on thecal plate patterns, the Protoperidinium species examined belonged to three subgenera and five defined morphological sections, with some sections represented by only one species.

Members of the Divergens section, characterized by a meta 1' plate and a quadra $2 \mathrm{a}$ plate, included two strains of Protoperidinium divergens (Ehrenberg) Balech, two strains of Protoperidinium crassipes (Kofoid) Balech, and one strain of Protoperidinium angustum (Dangeard) Balech (Figure 1). The plate patterns were the same in these species, so they were distinguished by differences in gross morphology. Protoperidinium divergens was slightly longer than wide (length $90 \mu \mathrm{m}$, width $75 \mu \mathrm{m}$ ), while $P$. crassipes was of approximately equal length and width (length $90 \mu \mathrm{m}$, width $90 \mu \mathrm{m}$ ). The sulcal lists of both species projected anteriorly, making the antapical horns appear to end in multiple spines. In $P$. divergens, the suture dividing the two antapical plates was shifted slightly to the left of center in the Irish strains examined here (Fig. 1 A-C). In $P$. crassipes strains from both Ireland and from the Gulf of Mexico (Fig. 1 D-I), the two antapical plates were more symmetrically divided, with the suture meeting the middle of the third post-cingular plate (3"'). The cingulum of $P$. crassipes formed a slight proximal arch on the left side to meet the excavated sulcus, which widened posteriorly. The degree of concavity of the epitheca appeared variable in culture. The cingulum of $P$. divergens was not offset. Protoperidinium angustum (Fig. $1 \mathrm{~J}-\mathrm{L}$ ) was a smaller species (length $70 \mu \mathrm{m}$, width $65 \mu \mathrm{m}$ ) with a more rounded epitheca and hypotheca. The ventral hypotheca was deeply excavated, tapering to very small antapical horns.

Several Protoperidinium morphological groups were represented by a single species. Protoperidinium pellucidum Bergh, with a para 1' plate and a hexa 2a plate was in the Pellucida group (Fig. 2 A-C). The Pyriforme group, with a meta 1' plate and a penta 2a plate was represented by Protoperidinium sp. 1 (Fig. 2 D-F), with a plate pattern and 
Figure 1.

Fluorescence micrographs of Calcofluor White-stained cells of Protoperidinium spp. in the Divergens section. Scale bars are $10 \mu \mathrm{m}$. (A-C) Protoperidinium divergens from western Ireland: (A) Ventral epitheca, showing meta 1' plate, cingulum not displaced. (B) Dorsal epitheca, showing quadra 2a plate. (C) Dorsal hypotheca with suture between antapical plates offset to the left. Antapical horns ending in multiple spines. (D-G) Protoperidinium crassipes from the Gulf of Mexico, FL: (D) Ventral side, with meta 1', displaced cingulum, and sulcus widening antapically. (E) Dorsal side, with quadra 2a plate. (F) Dorsal hypotheca, with centered suture between anapical plates and antapical horns ending in multiple spines. (G) Epitheca, with meta 1' plate. (H-I) Protoperidinium crassipes from western Ireland: (H) Ventral epitheca, with meta 1' plate. (I) Dorsal epitheca with quadra 2a plate. (J-L) Protoperidinium angustum: (J) Ventral epitheca with meta 1' plate. (K) Dorsal epitheca with quadra 2a. (L) Dorsal side, showing cell shape, cingular and sulcal lists, and pointed antapical horns. 


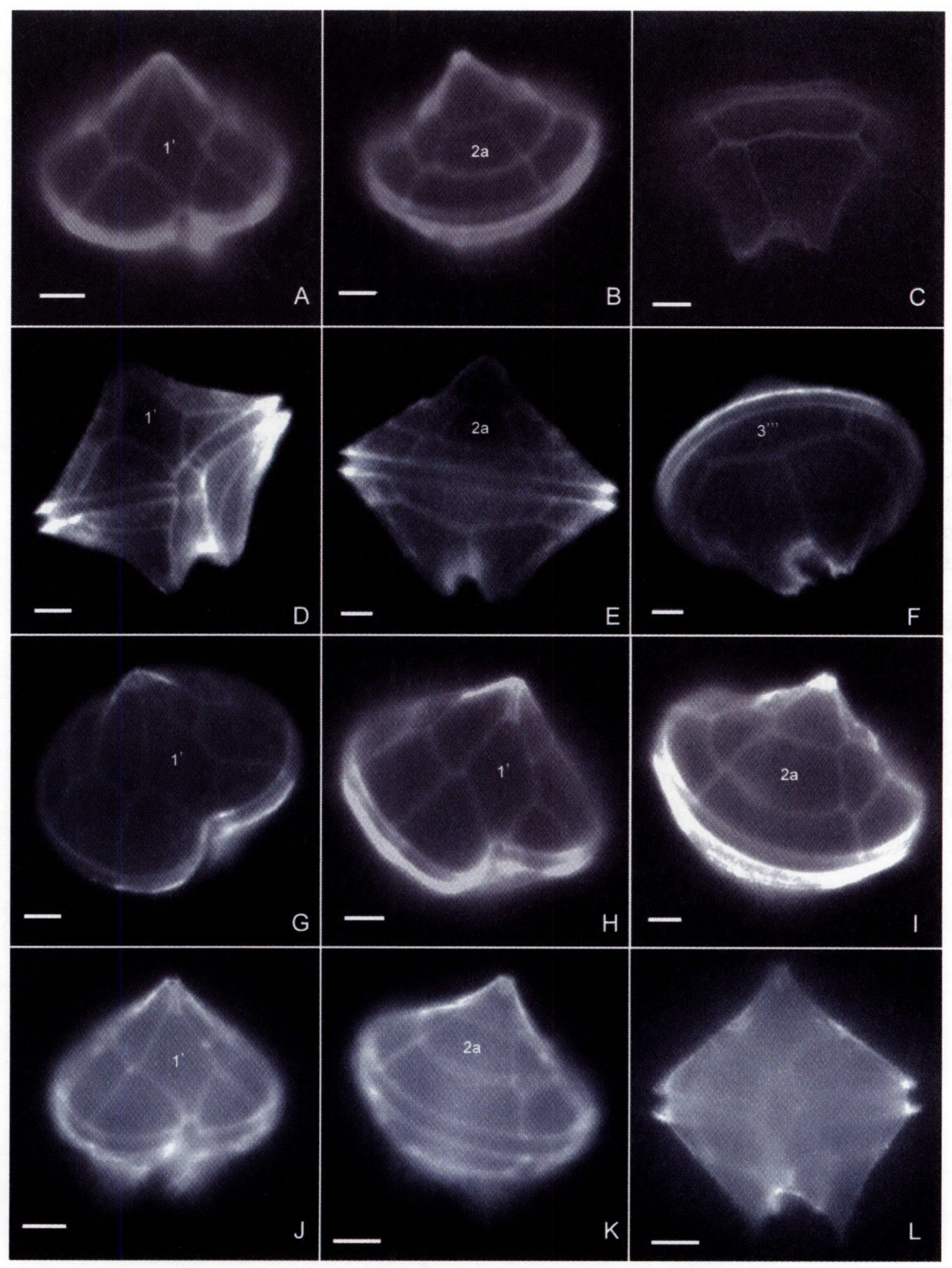


Figure 2.

Fluorescence micrographs of Calcofluor-white stained cells and SEM micrographs of Protoperidinium spp. in the Pellucida, Pyriforme, Conica, and Excentricum sections. Scale bars are $10 \mu \mathrm{m}$. (A-C) Protoperidinium pellucidum: (A) Ventral side showing para 1' plate, slight displacement of cingulum, solid antapical spines and large sulcal list on left side. (B) Expanded view of ventral epitheca. (C) Top view of epitheca, showing hexa 2a plate. (D-E) Protoperidinium sp. 1: (D) Ventral epitheca, with meta 1' plate and cingular lists supported by spines. (E) Dorsal epitheca showing penta 2a plate. (F) Dorsal hypotheca, showing 2 antapical plates and solid, winged antapical horns. (G-H) Protoperidinium conicoides: (G) Ventral side of cell, with ortho 1' plate and deeply excavated sulcus. (H) Dorsal epitheca, showing para 2a plate. (I-L) Protoperidinium excentricum: (I) Side view, showing cell shape with equilatoral cingulum and apical horn displaced to ventral side of cell. (J) Dorsal epitheca, showing small 3' plate, portion of la plate, and very large 2 a plate extending across most of dorsal epitheca. (K) Left side of epitheca, showing 1a plate. (L) Hypotheca, with sulcus extending to center of hypotheca, two antapical plates, and absence of antapical horns. 


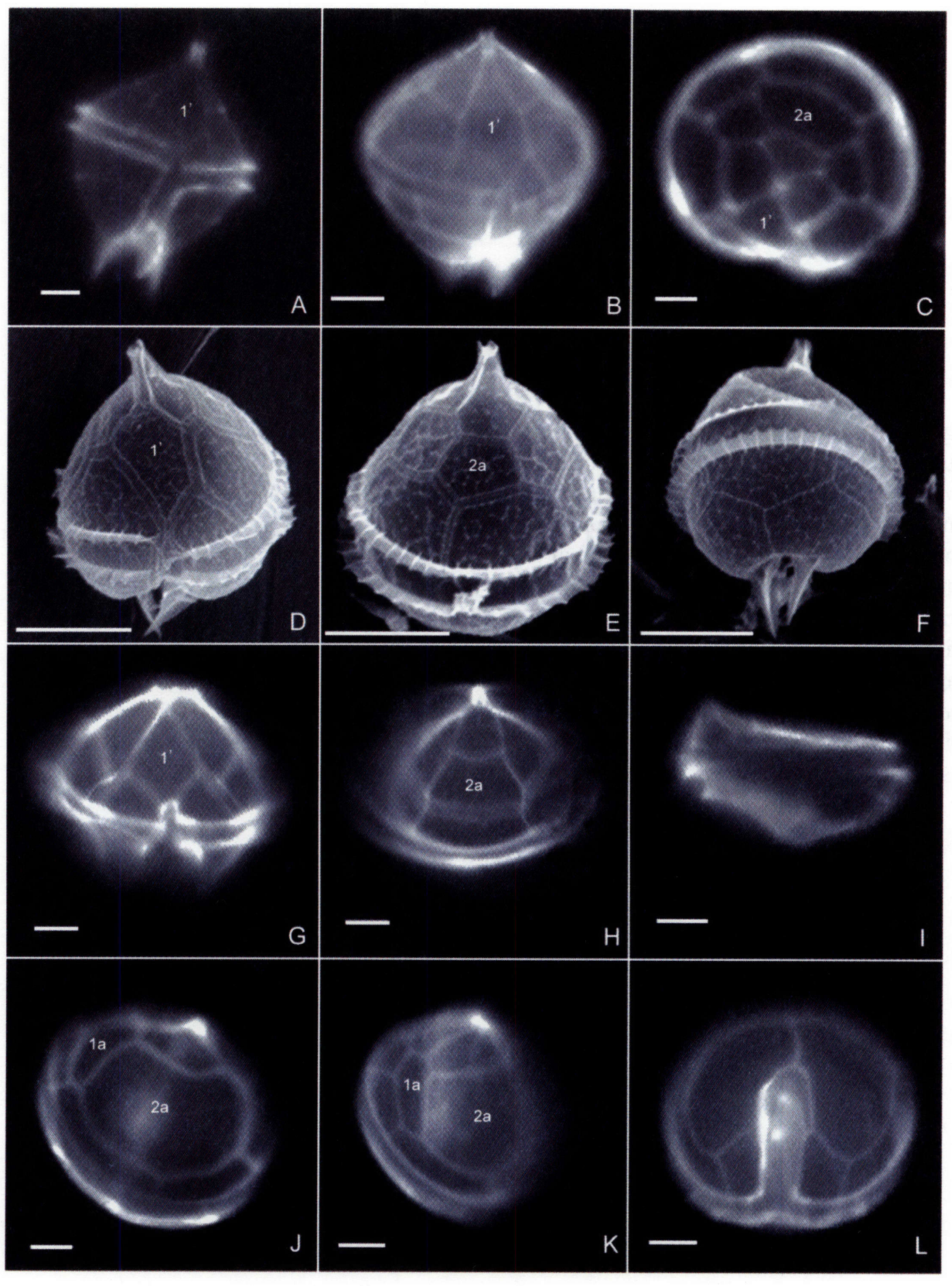


Figure 3.

Fluorescence micrographs of Calcofluor White-stained cells and SEM micrographs of Protoperidinium spp. in the Oceanica section and subgenus Testeria. Scale bars are 10 $\mu \mathrm{m}$. (A-C) Protoperidinium oblongum: (A) Ventral epitheca, with ortho 1' plate, tapering to long apical horn. (B) Dorsal hypotheca, showing large 3"' plate and two long antapical horns. (C) Dorsal epitheca, with quadra 2a plate. (D-E) Protoperidinium steidingerae: (D) Ventral view, showing central, ventral, epithecal plate separated from apical pore, displaced cingulum, with lists, and sulcus with lists. (E) Dorsal epitheca, single intercalary plate appears continuous with small apical plate. (F-H) Protoperidinium depressum: (F) Ventral epitheca, with ortho 1' plate. (G) Top view of epitheca, showing ortho 1' and quadra 2a plates. (H) Dorsal hypotheca with large 3", post-cingular plate, two smaller antapical plates, and small hollow antapical horns. 


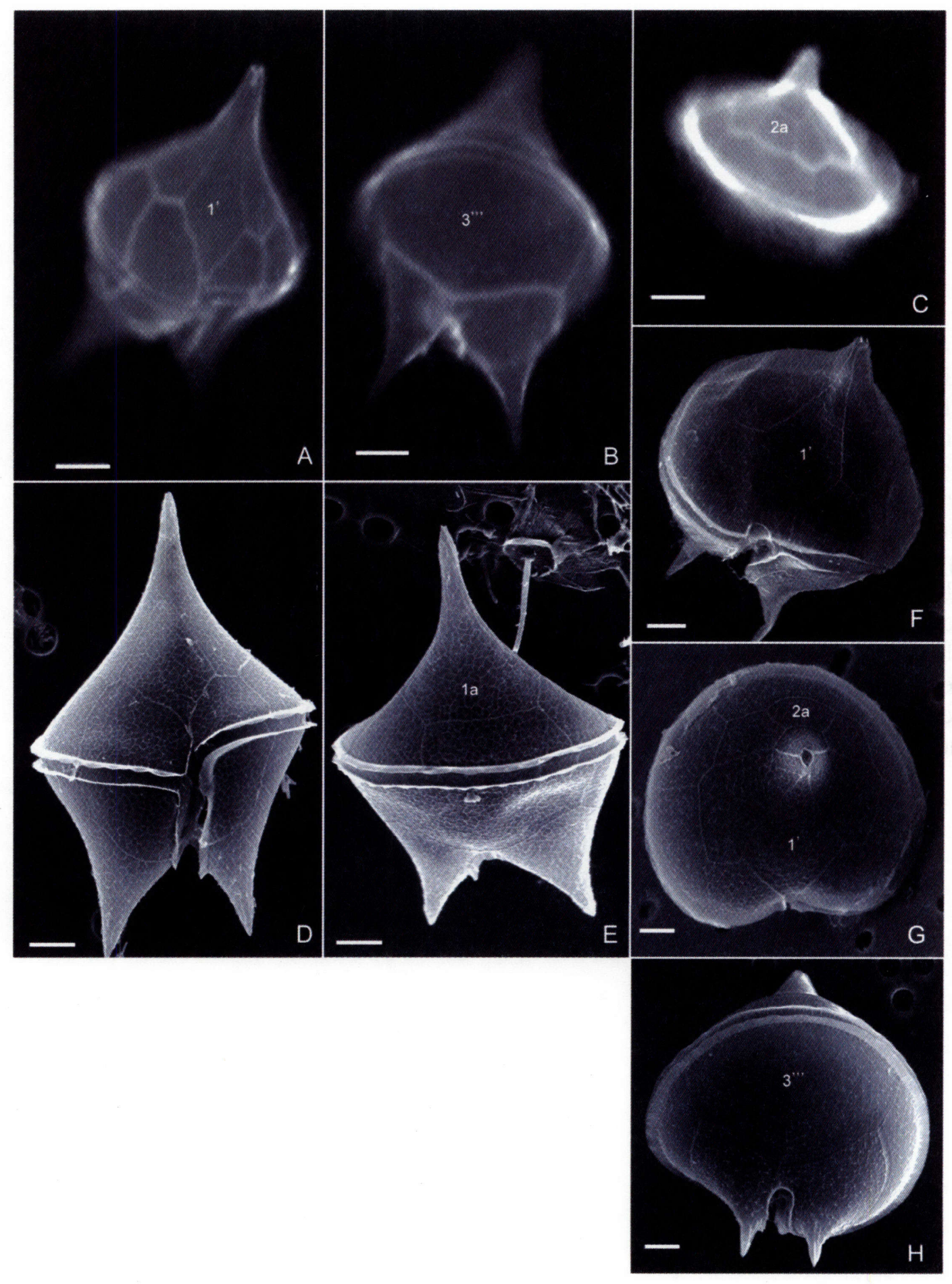


Figure 4.

Fluorescence micrographs of Calcofluor White-stained cells and SEM micrographs of diplopsalid heterotrophic dinoflagellates. Scale bars are $10 \mu \mathrm{m}$. (A-D) Diplopsalis lenticula: (A) Dorsal epitheca, showing single, wide intercalary plate. (B) Hypotheca, with single antapical plate and pronounced list on left side of sulcus. (C and D) Epitheca, showing ortho 1' plate with extended upper triangle and shortened lower triangle. In (C), epitheca divided unequally, with 2' plate half the size of the 3' plate. In (D), 2' and 3' plates are the same size. (E-H) Preperidinium meunieri: (E) Ventral epitheca, with narrow, long, ortho 1' plate and diamond-shaped 1a plate. (F) Ventral view of slightly globular cell with equilateral cingulum. Post-cingular plates 1" and 5", extending nearly to bottom of sulcus. (G) Top view of epitheca, showing three apical plates on ventral side of cell, diamond shaped la plate, and large 2 a plate extending across dorsal side of epitheca. $(\mathrm{H})$ Hypotheca, with single antapical plate. 


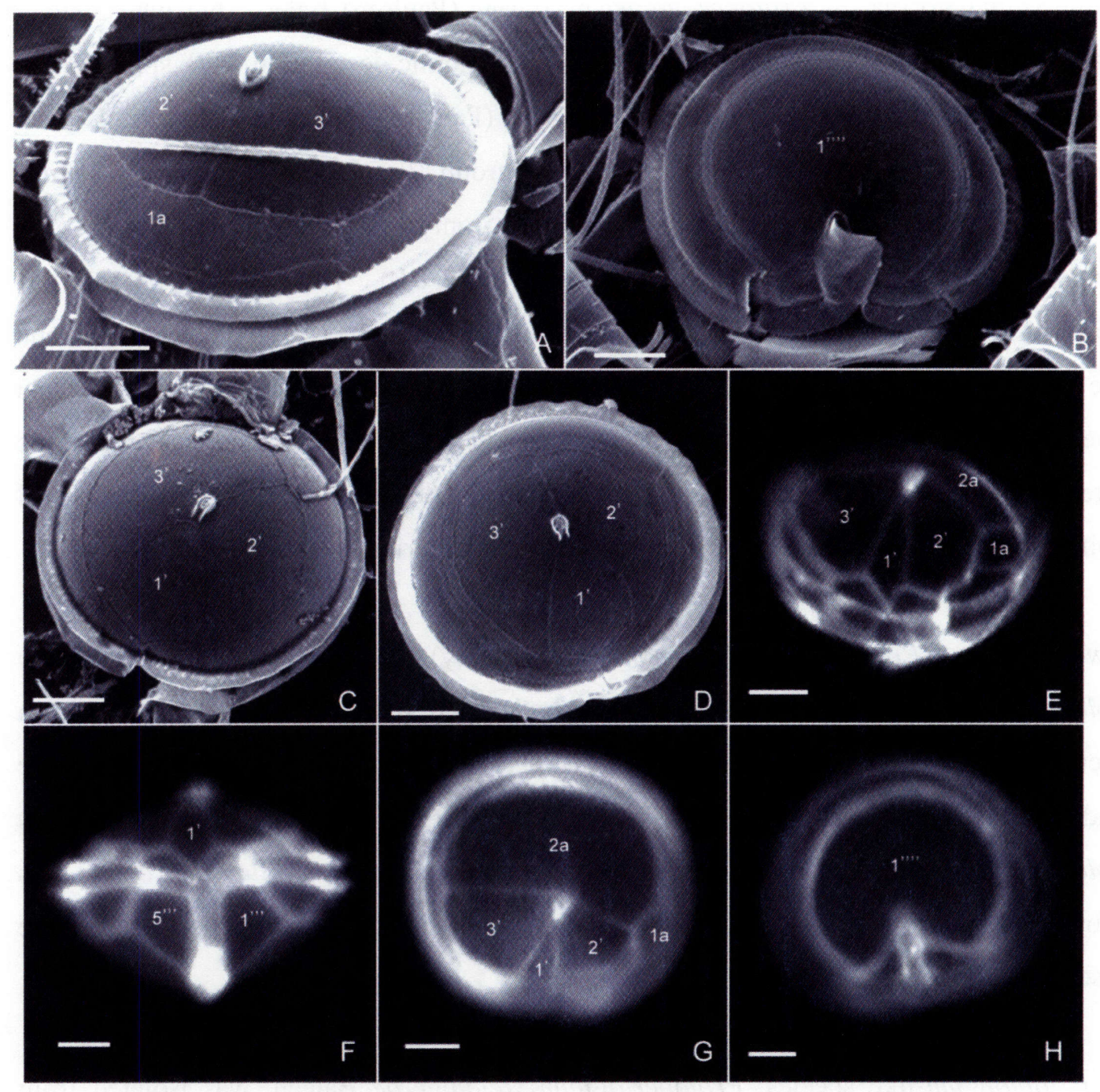


shape similar to that of Protoperidinium pyriforme (Paulsen) Balech, but whose small size precluded that species designation. A full taxonomic description of $P$. sp. 1 will be presented elsewhere. Protoperidinium conicoides (Paulsen) Balech had an ortho 1' plate and a hexa 2a plate, placing it in the Conica group (Fig. 2 G-H). In the subgenus Archaeperidinium, members of which have only two antapical plates, was Protoperidinium excentricum (Paulsen) Balech (Fig 2 I-L). This species was anteriorposteriorly compressed, with an apical horn displaced to the ventral side of the cell, and the sulcus extending to the center of the hypotheca. Protoperidinium excentricum had one small six-sided intercalary plate on the left side of the epitheca, and a second, large intercalary plate covering the majority of the dorsal side of the cell. The asymmetrical epitheca of the species placed it within the section Excentrica.

Two species, Protoperidinium depressum (Bailey) Balech and Protoperidinium oblongum (Aurivillius) Parke and Dodge, both from Ireland, were in the Oceanica section, with ortho 1' and quadra 2a plates (Fig. 3 A-C, F-H). Both species were large and had the same thecal plate pattern but different gross morphology. Protoperidinium oblongum was long and dorso-ventrally compressed. Protoperidinium depressum was broad and round at the cingulum, with the concavity of the ventral apex lending the distinctive "tilt" to the cell.

A $P$. oblongum-like species, Protoperidinium steidingerae Balech, was isolated from Vineyard Sound, Woods Hole, Massachusetts (Fig. 3 D-E). Protoperidinium steidingerae had one intercalary plate and a single ortho apical plate on the ventral side that did not reach the apex of the apical horn (Fig 3E). This species falls within the recently defined subgenus Testeria, given that it has only one apical plate and lacks an apical pore (Faust 2006).

The two lenticular species studied, Preperidinium meunieri (syn. Zygabikodinium lenticulatum) and Diplopsalis lenticula, both had a pronounced list on the left side of the 
sulcus, an equatorial girdle, three apical plates with an ortho 1' apical plate in which the anterior triangle was longer than the posterior triangle, and a single antapical plate (Fig. 4 A-H). In Diplopsalis lenticula, there were three apical plates, with a relatively wide 1' plate (Fig. 4A). The relative sizes of the 2' and 3' plates varied, ranging from equal in size to unequal, so that the 2' plate was one-half the size of the 3' plate (Fig 4 C-D). There was a single, narrow, long intercalary plate, and six narrow precingular plates. Preperidinium meunieri (Fig. 4 E-H) was more globular in shape and had a thinner 1' plate than did D. lenticula. A small, four-sided intercalary plate (1a) was on the left side

of Preperidinium meunieri, a second, large intercalary (2a) plate occupied the dorsal half of the epitheca, nearly contacting the apical pore, and there were seven precingular plates.

\section{Sequence variability}

In attempting to sequence directly from PCR products, we found high intraindividual variability in the LSU rDNA, requiring sequencing from cloned PCR products. The sequence used for phylogenetic analysis of a given species was the most abundant sequence in the clone library from multiple single-cell PCR reactions for that species. Results regarding intraindividual sequence variability will be presented separately.

Interestingly, the site of the D3B primer, useful in many other studies of dinoflagellate phylogeny, was variable within the Protoperidinium and diplopsalid dinoflagellates in this study, necessitating the development of new internal primers for sequencing most species (Table 4).

\section{Phylogenetic analyses}

\section{Dinoflagellate phylogeny}

Two dinoflagellate phylogenies that include the Protoperidinium, Preperidinium, and Diplopsalis are presented. Figure 5 provides the results of MP analysis, with bootstrap support from MP and NJ analyses. Figure 6 gives a tree from ML analysis, supported by bootstrap values from $\mathrm{ML}$ and posterior probability values from Bayesian analyses. 


\section{Figure 5.}

Maximum parsimony tree based on domains D1-D3 of the LSU rDNA gene. Bootstrap values greater than $50 \%$ are shown, with values from maximum parsimony bootstrap (1000 replicates) above the node and values from neighbor joining bootstrap (1000 replicates) below the node. Two ciliates and one apicomplexan were used to root the tree. 


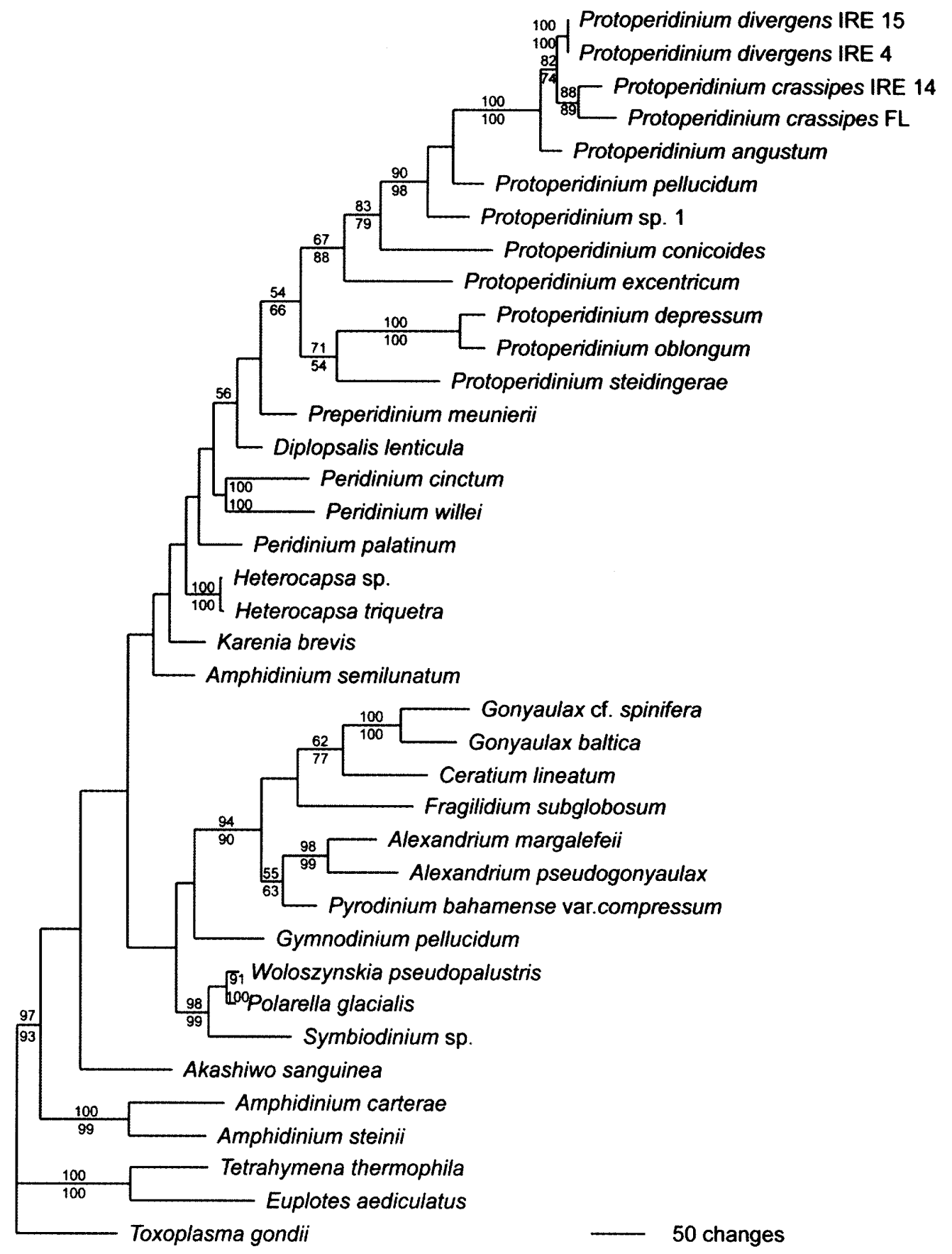


Figure 6.

Maximum likelihood tree based on domains D1-D3 of the LSU rDNA gene. Bootstrap values from maximum likelihood (100 replicates) greater than $50 \%$ are shown above the node. Posterior probabilities from Bayesian analysis (1,000,000 generations), given as a percent, are shown below the node. Two ciliates and one apicomplexan were used to root the tree. 


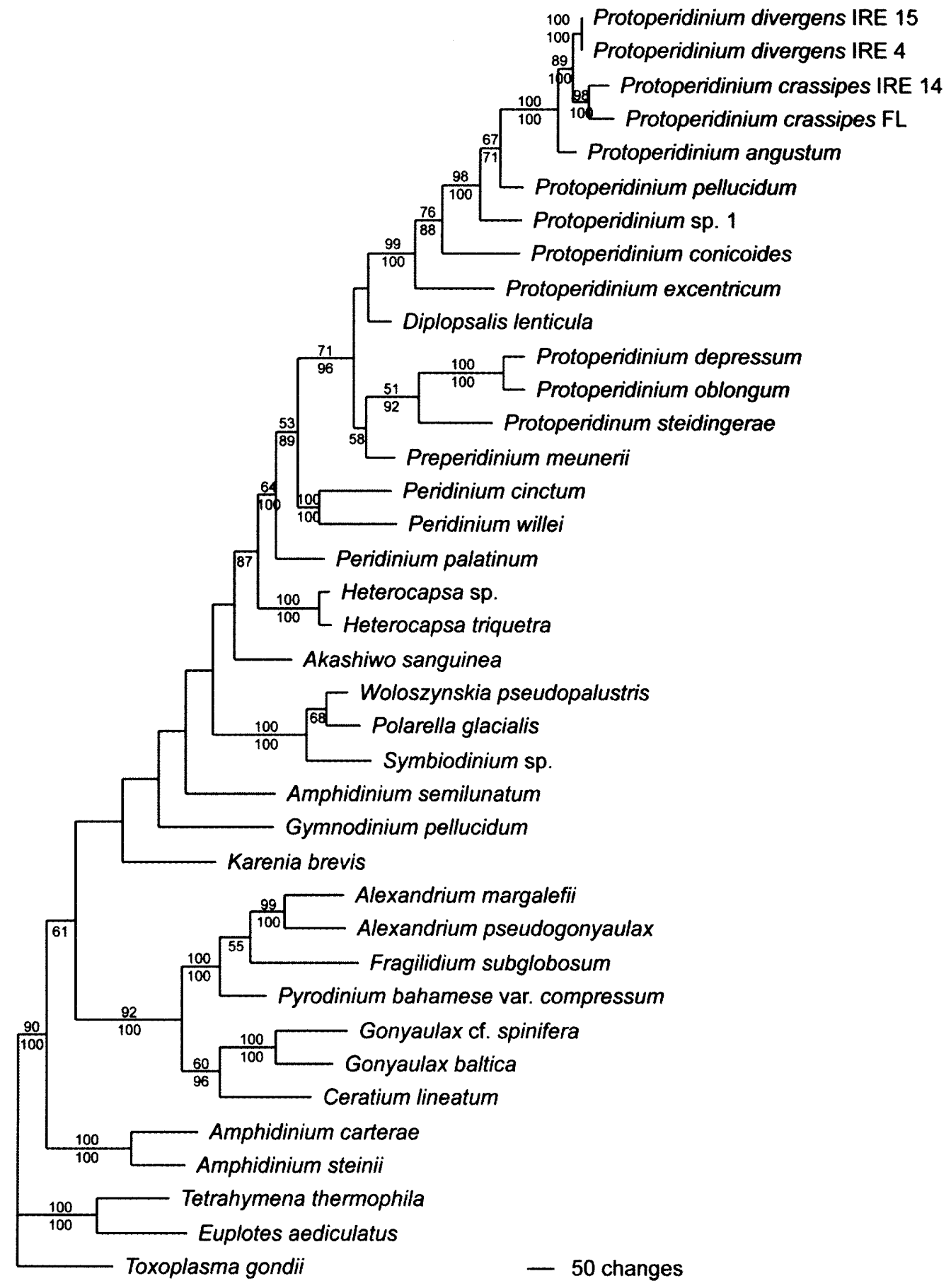


Figure 7.

Partial maximum parsimony tree based on domains D1-D3 of the LSU rDNA gene. Bootstrap values greater than $50 \%$ are shown. Values above the node are bootstrap support from maximum likelihood / posterior probabilities from Bayesian analysis and values below the node are bootstrap support from maximum parsimony / neighbor joining. 


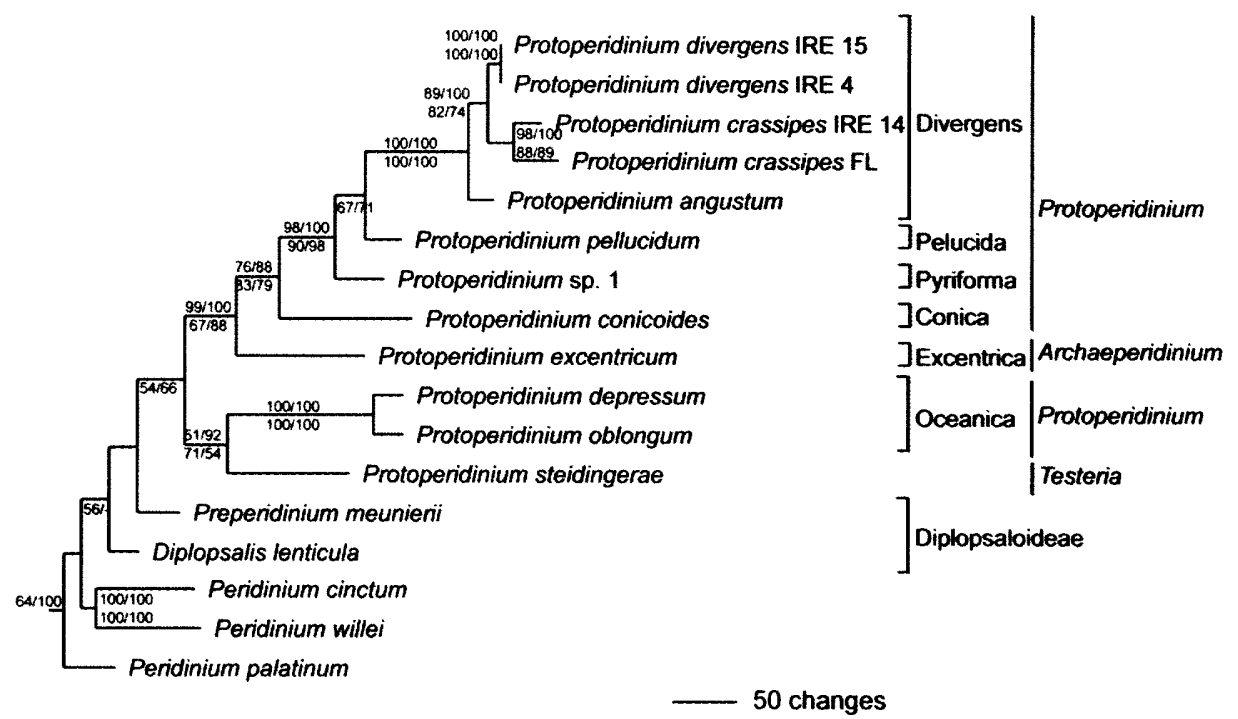


The phylogenetic trees from MP and ML analyses shared many features. Uncertainties at particular nodes in a given tree, indicated by low bootstrap support, were often supported by higher bootstrap values in the other tree. In both trees, the major groupings of dinoflagellates were present. As is the case with many LSU and SSU rDNA phylogenies of the dinoflagellates, the branching order between these groups is poorly defined, with low bootstrap support for many deeper branches, and with branching order dependent upon the model of evolution and the method of analyses employed. The Gonyaulacoides form a monophyletic group with high support in all analyses. As in LSU and SSU rDNA phylogenies constructed by others, the Gymnodinales are scattered throughout the tree. Amphidinium carterae Hulburt and Amphidinium steinii Lemmermann diverged early, while Amphidinium semilunatum Herdman is placed more recently. Symbiodinium sp. Freudenthal falls into a clade with two gymnodinales, Woloszynskia pseudopalustris (Woloszynska) Kisselew and Polarella glacialis Montresor, Procaccini and Stoecker. Placement of Fragilidium subglobosum (von Stoch) Loeblich III within the Gonyaulacoides varied depending upon analysis, although its position within the Alexandrium Halim clade in the ML tree is most likely, given the support by Bayesian analysis, and lack of high bootstrap support for placement with Gonyaulax spp. Diesing and Ceratium lineatum (Ehrenberg) Cleve in the MP tree.

The thecate, heterotrophic, marine Protoperidinium, Diplopsalis, and Preperidinium diverged from the primarily freshwater, phototrophic Peridinium spp. in all analyses--a result well-supported in both ML and Bayesian analyses, but not in MP or NJ analyses. The other Peridinaceae species included in the study, Heterocapsa spp. Stein, are basal to the Peridinium spp.

\section{Phylogeny within the thecate heterotrophic dinoflagellates}

The Protoperidinium appeared to be recently divergent in all analyses. In MP and NJ analysis, the Protoperidinium formed a monophyletic group, albeit with low bootstrap support, evolving from the diplopsalid dinoflagellates. In ML and Bayesian analyses, 
however, the Protoperidinium were paraphyletic, as the diplopsalid, D. lenticula, was inserted, with low bootstrap support, within the Protoperidinium clade as basal to $P$. excentricum, and Preperidinium meunieri falls, with low bootstrap support, within a separate clade as a sister to the Oceanica and Testeria. A partial MP tree, showing just the Peridinium spp., Protoperidinium spp. and the diplopsalids is shown in Figure 7.

Whether monophyletic or polyphyletic, the Protoperidinium spp. branched into two major clades, one containing the Oceanica section and $P$. steidingerae, and the other clade containing all other morphological sections, including the subgenus Archaeperidinium. In the first major clade, $P$. steidingerae, in the subgenus Testeria, was a sister to the Oceanica species, $P$. depressum and $P$. oblongum. The second major clade, in which $P$. excentricum was the basal-most species, contained all other morphological sections of Protoperidinium. Single representatives from major morphological groupings each branched separately-- $P$. conicoides in the Conicum section was basal to Protoperidinium sp. 1 in the Pyriforme group, which in turn was basal to $P$. pellucidum of the Pellucida group. Members of the Divergens section, including $P$. angustum, $P$. crassipes and $P$. divergens, were most the derived. Two strains of $P$. divergens were included, both from the same region of Ireland and both with the same sequence. Two strains of $P$. crassipes, one from Ireland the other from the Gulf of Mexico, were more closely related to one another than to $P$. divergens. $P$. angustum was most basal in the Divergens section.

\section{DISCUSSION}

This study helps to elucidate the relationship between molecular evolution and morphology in the thecate heterotrophic dinoflagellates, in an effort to sort out the confused taxonomies of the Protoperidinium and diplopsalids. While the historical morphological sections defined for these groups are evolutionarily germane, the lineage of those groups is not so straightforward. 


\section{Single-cell PCR}

In the past few years, single-cell PCR has become more commonly employed in molecular genetic investigations of dinoflagellates (Bolch 2001; Sebastián and O'ryan 2001; Godhe et al. 2002; Rehnstam-Holm et al. 2002; Yamaguchi and Horiguchi 2005). In this study, we performed PCR reactions directly on single-cells, without DNA extraction. Given that even washing in DI water did not always rupture the thecate cells, we increased the number of successful PCR reactions by freezing isolated cells in DI water overnight at $-80^{\circ} \mathrm{C}$ and then sonifying in a water bath to enhance cell lysis.

Single-cell PCR allowed the heterotrophic dinoflagellates to be separated from their phytoplankton prey, which are often the same size as the heterotrophs, and thus not easily removed. Single-cell PCR also allowed isolation of these difficult-to-culture species directly from field samples, as was done for three species in this study. Working directly from field samples meant we could obtain sequence data in cases where we did not want to culture ( $P$. conicoides and Preperidinium meunieri) or were unable to culture $(P$. excentricum) the heterotrophic dinoflagellates. The majority of thecate heterotrophs investigated were cultured, however, to confirm species identifications and to examine the range of morphological variability within a given species.

\section{Species identification}

Accurate verification of the thecal plate morphology for each species and ample replication of PCR reactions was possible because most species examined were maintained in culture. Cultures also allowed us to better distinguish interspecific from intraspecific morphological and sequence variability. For example, the relative sizes of the 2' and 3' plates varied widely in D. lenticula. In $P$. divergens, the suture between the antapical plates was shifted left of center in the strains analyzed, a trait not described in the literature. Many of the Protoperidinium species studied here exhibited a variety of morphologies throughout their life cycles, including isogamous gametes and a reduction to approximately half to three-quarters of the original size at the time of cell division. 
Protoperidinium oblongum cells in clonal culture, for example, ranged in length from 60 $\mu \mathrm{m}$ to $150 \mu \mathrm{m}$ in culture, and cells in clonal cultures of $P$. depressum similarly ranged in width from $40 \mu \mathrm{m}$ to $120 \mu \mathrm{m}$. Protoperidinium steidingerae varied from $35 \mu \mathrm{m}$ long gametes to $140 \mu \mathrm{m}$ long vegetative cells. If such morphologically-distinct life stages were isolated from field samples, they would likely be mis-identified as separate species.

Although longer sequences or data from multiple genes likely would have improved the accuracy of the tree topology for the Protoperidinium and diplopsalids, because of the taxonomic uncertainty in these heterotrophic groups, we could not concatenate the SSU sequences from separate strains examined in previous studies (Saldarriaga et al. 2004; Yamaguchi and Horiguchi 2005) with the LSU rDNA data generated in this study. Despite the similarity of names of some species in the three studies, including $P$. pellucidum, $P$. crassipes, $P$. divergens, and $P$. excentricum in this study and either one or both of the other two studies, we may have been dealing with different species or genetically distinct strains of the same species. Protoperidinium crassipes and $P$. curtipes, for example have been viewed by some as synonymous, while others separated the two, choosing one name or the other (Taylor 1976; Abé 1981; Dodge 1982).

\section{Sequence variability}

Yamaguchi and Horiguchi (2005) reported intraspecific variability in the SSU rDNA for Protoperidinium spp. collected from the same area. Such diversity of the slowlyevolving SSU rDNA within a population is surprising, unless there has been importation of the same species from another area. Cloning the PCR products of the SSU rDNA and sequencing the clones, rather than the PCR products, might have revealed that the sequence variability was actually intracellular, in the form of pseudogenes in SSU rDNA, as we have found in the LSU rDNA (Chapter 5, this thesis). Pseudogenes, multiple, nonfunctional copies of both SSU and LSU rDNA genes, have been found in other dinoflagellates species (Scholin et al. 1993; Yeung et al. 1996; Santos et al. 2003). These different gene copies have generally been found in approximately equal abundance. 
Randomly preferential PCR amplification of one copy over another, as could be more likely when starting from the low template concentrations found in single-cell PCR, could give results that appear to be intraspecific variability at a single field location.

The sequence at the site of the D3B primer varied among the thecate heterotrophic species examined in this study, requiring development of new primers for sequencing on nearly a species-by-species basis. The D3B primer, designed for studies of the Isopoda (Nunn et al. 1996) has been used successfully in phylogenetic investigations of a range of other dinoflagellate taxa, including Alexandrium, Gymnodinium, Dinophysis Ehrenberg, and Polykrikos Kofoid and Swezy (Hansen et al. 2000; Bolch 2001; Hansen et al. 2003) and is considered to lie within a relatively well-conserved region. The variability of this site in these thecate heterotrophs may have contributed to the difficulty others have reported in obtaining PCR products from Protoperidinium using the D3B primer (Bolch 2001).

\section{Phylogeny of the Protoperidinium, Diplopsalis, and Preperidinium}

Results from this study indicate that the Peridinaceae gave rise first to the Diplopsaloideae, from which the Protoperidinium then arose. These findings differed slightly from the hypothetical, parsimonious, morphology-based model of evolution proposed by Taylor (2004), in which a plate-reduction model predicted evolution from the Peridinium, with three intercalary plates and five or six cingular plates, to the Protoperidinium, and to the Protoperidinium having then given rise to the diplopsalids, which have only one or two antapical plates and one or two intercalary plates. Similarity in thecal plate morphology supported the close evolutionary relationship between the Protoperidinium and Peridinium that we found, which differed from the two other dinoflagellates phylogenies that included Protoperidinium to date (Saldarriaga et al. 2004; Yamaguchi and Horiguchi 2005). These previous works were both based on SSU rDNA sequences, and suggested that the Protoperidinium were not closely related to the

Peridinium. These previous studies also argued that the Protoperidinium is a 
monophyletic genus within the dinoflagellates (Saldarriaga et al. 2004; Yamaguchi and Horiguchi 2005), in agreement with our maximum parsimony results. Our maximum likelihood results indicate that the Protoperidinium may be polyphyletic, however. The inclusion in this study of diplopsalid species and of a wider range of morphological sections of the Protoperidinium, in particular members of the Oceanica and the subgenus Testeria, likely lead to the disparity between the studies. The Oceanica and $P$. steidingerae formed a sister group to the rest of the Protoperidinium, and the diplopsalids appear to be basal to Protoperidinium spp., so including these groups may have provided a stronger link to the common ancestor of the Peridinium and the Protoperidinium.

Thecal plate morphology appears to have relevance to the intrageneric molecular phylogeny, as the Protoperidinium spp. grouped strongly by morphological section as determined from thecal plate patterns (Fig. 7). There is not, however, a straightforward evolutionary lineage in the shape of either the 1' or the 2a plate. Species with para or meta 1' plates seem to have evolved from species with ortho 1' plates. The Orthoperidinium is not monophyletic, however, as $P$. conicoides and $P$. excentricum branch separately from the Oceanica clade containing $P$. depressum and $P$. oblongum.

Cyst morphology may also be correlated with molecular phylogeny, although the cysttheca relationships are not known for all species in this study. Like most diplopsalids, $D$. lenticula and $P$. meunieri have unornamented, spherical brown cysts, in which the archeopyle forms a slit without a detached operculum (Wall and Dale 1968; Matsuoka 1988). In the Oceanica and Testeria clade, both $P$. oblongum and $P$. steidingerae have smooth-walled, rhomboidal to chordate, dorso-ventrally compressed cysts with intercalary archeopyles and apical horns that vary from long and narrow to short and rounded (Wall and Dale 1968, K. Gribble, unpubl. data). No cyst has ever been reported for $P$. depressum, despite the species' cosmopolitan nature and easily recognized morphology, so it may be that not all species in the Oceanica clade have cysts. In the other major clade of Protoperidinium, both $P$. excentricum and $P$. conicoides have round, 
unornamented, brown cysts, compressed in either a polar or dorso-ventral direction, respectively. No cysts have been reported for $P$. pellucidum or for any of the species included in this study in the Divergens clade. Additional cyst-forming heterotrophic dinoflagellate species from a variety of morphological sections would need to be added to validate the relationship between molecular phylogeny and cyst morphology.

Protoperidinium excentricum, a species in the subgenus Archaeperidinium and the section Excentrica, is most basal within the larger clade of Protoperidinium species, making the subgenus Protoperidinium polyphyletic. Based on morphology, the placement of $P$. excentricum, which has only two intercalary plates and a compressed shape unlike that of any other Protoperidinium species, was unexpected. In a SSU rDNA phylogeny of the Protoperidinium, the Avellena section within the Archaeperidinium appears to have evolved from, or perhaps even fall in within the same clade as, the Conica (Yamaguchi and Horiguchi 2005). A single phylogeny including both the Avellana and the Excentricum is required to determine the unity of the Archaeperidinium. As additional species are sequenced, the distinction of the Archaeperidinium as a subgenus or the placement of the Oceanica within the subgenus Protoperidinium may have to be reconsidered.

The Divergens section formed a single clade, diverging from the Pellucida section as was also observed in a phylogeny based on SSU rDNA (Yamaguchi and Horiguchi 2005). Taxonomy and species classification within the Divergens section has always been problematic. Protoperidinium crassipes and $P$. curtipes, for example, have been separated as two species and united as a single species (called variously $P$. crassipes or $P$. curtipes) repeatedly to the present day. We are unable to make judgments about the species designations of $P$. crassipes from $P$. curtipes based on the sequences and level of morphological examination of the two strains studied here. We did see range in cell widths from $65 \mu \mathrm{m}$ to $90 \mu \mathrm{m}$ in cultured $P$. crassipes from the Gulf of Mexico, however, and a range of coloration (used by some to distinguish the species) from pale yellow to 
pale pink to dark pink. Based on the relatively modest concavity of the apical and antapical horns, and the slight displacement of the cingulum, similar to Kofoid's original description (Kofoid 1907), we have designated these two strains as $P$. crassipes. Additional strains of $P$. crassipes must be brought into culture to observe the variability in concavity of the epitheca and the degree of arch to the cingulum, and to obtain sequences to determine if $P$. crassipes and $P$. curtipes are separate species.

This work and other dinoflagellate molecular phylogenies have barely scratched the surface of the diversity of the Protoperidinium and Diplopsaloideae. In this survey, we examined only two species of diplopsalids and only 10 species of Protoperidinium in three subgenra and five morphological sections, out of the more than 200 described Protoperidinium species. Additional species in the Diplopsaloideae need to be included, to determine whether this group is evolutionarily coherent, or if these species do indeed fall within the Protoperidinaceae. Working from cultures, though time-consuming, provides the opportunity for more thorough investigation of the importance of gross morphology, including size, shape, and the absence or presence and nature of apical and antapical horns, to phylogeny. Many more species of Protoperidinium must be incorporated into future analyses, including those from other taxonomic sections and additional members of the morphological groups represented here. This will help to determine whether the morphologically-defined classifications are truly evolutionarily relevant for this important group of organisms.

\section{ACKNOWLEDGEMENTS}

We would like to thank the Marine Institute, Ireland, for enabling sample collection in Ireland, and Trish Blum of the Mote Marine Laboratory and David Kulis of the Woods Hole Oceanographic Institution for sample collection. Thanks to the captains and crews of the R/V Celtic Voyager, Irish Marine Institute and the $\mathrm{R} / \mathrm{V}$ Tioga, Woods Hole Oceanographic Institution. We thank Malte Elbrächter for assistance with identification of $P$. steidingerae. Thank you to two anonymous reviewers for constructive comments. 
Funding for this project came from the Comer Fellowship, the Carroll Wilson Award from the MIT Entrepreneurship Society, and the Cove Point Foundation.

\section{REFERENCES}

Aвé, T. H. 1981. Studies on the Family Peridiniidae: An Unfinished Monograph of the Armoured Dinoflagellata. Academia Scientific Book, Inc.

BALECH, E. 1974. El genero Protoperidinium Bergh, 1881 (Peridinium Ehrenberg, 1831, Partim). Revista del Museo Argentino de Ciencias Naturales "Bernardino Rivadavia" e Instituto Nacional de Investigacion de las Ciencias Naturales 4: 179.

BERGH, R. S. 1881. Der organismus der Cilioflagellaten. Morph. Jahrb. 7: 177-288.

BoLCH, C. J. S. 2001. PCR protocols for genetic identification of dinoflagellates directly from single cysts and plankton cells. Phycologia 40: 162-167.

DaugbJerg, N., G. Hansen, J. LARSEn, and Ø. Moestrup. 2000. Phylogeny of some of the major genera of dinoflagellates based on ultrastructure and partial LSU rDNA sequence data, including the erection of three new genera of unarmoured dinoflagellates. Phycologia 39: 302-317.

DoDGE, J. D. 1982. Marine Dinoflagellates of the British Isles. Her Majesty's Stationery Office.

DODGE, J. D., and H. HERMES. 1981. A revision of the Diplopsalis group of dinoflagellates (Dinophyceae) based on material from the British Isles. Botanical Journal of the Linnean Society 53: 15-26.

ElbräCHTER, M. 1993. Kolkwitziella Lindemann 1919 and Preperidinium Mangin 1913: correct genera names in the Diplopsalis-group (Dinophyceae). Nova Hedwigia 56: $173-178$.

EllegaArd, M., N. Daugbjerg, A. Rochon, J. Lewis, and I. Harding. 2003. Morphological and LSU rDNA sequence variation within the Gonyaulax spinifera-spiniferites group (Dinophyceae) and proposal of $G$. elongata comb. nov. and G. membranacea comb. nov. Phycologia 42: 151-164. 
Faust, M. A. 2006. Creation of the subgenus Testeria Faust subgen. nov. Protoperidinium Bergh from the SW Atlantic Ocean: Protoperidinium novella sp. nov. and Protoperidinium conicinna sp. nov. Dinophyceae. Phycologia 45: 1 9.

Fensome, R. A., F. J. R. Taylor, G. Norris, W. A. S. Sarjeant, D. I. Waharton, and G. L. WiLliams. 1993. A classification of living and fossil dinoflagellates. Micropaleontology, Special Publication Number 7: 1-351.

FrITZ, L., and R. E. TRIEMER. 1985. A rapid simple technique utilizing Calcofluor white $\mathrm{M} 2 \mathrm{R}$ for the visualization of dinoflagellate thecal plates. Journal of Phycology 21: 662-664.

Godhe, A., D. M. Anderson, and A. S. Rehnstam-Holm. 2002. PCR amplification of microalgal DNA for sequencing and species identification: studies on fixatives and algal growth stages. Harmful Algae 1: 375-382.

GUILLARD, R. R. L. 1975. Culture of phytoplankton for feeding marine invertebrates. In W. L. Smith and M. H. Chanley [eds.], Culture of Marine Invertebrates. Plenum Publishing Corporation.

Hansen, G., N. Daugbjerg, and J. M. Franco. 2003. Morphology, toxin composition and LSU rDNA phylogeny of Alexandrium minutum (Dinophyceae) from Denmark, with some morphological observations on other European strains. Harmful Algae 2: 317-335.

Hansen, G., N. DaugbJerg, and P. Henriksen. 2000. Comparative study of Gymnodinium mikimotoi and Gymnodinium aureolum, comb. nov. (=Gyrodinium aureolum) based on morphology, pigment composition, and molecular data. Journal of Phycology 36: 394-410.

JACOBSON, D. M., and D. M. ANDERSON. 1986. Thecate heterotrophic dinoflagellates: Feeding behavior and mechanisms. Journal of Phycology 22: 249-258.

JEONG, H. J. 1996. The predation impact by the heterotrophic dinoflagellate Protoperidinium cf. divergens on copepod eggs in the presence of co-occurring phytoplankton prey. Journal of the Oceanological Society of Korea. Seoul 31: 144-149.

JÖRGENSEN, E. 1912. Bericht über die von der schwedischen hydrographischbiologischen Kommission in den schwedischen Gewässern in den Jahren 1909- 
1910 eingesammelten Planktonproben. Svenska Hydrogr.-Biol. Komm. Skr. 4: 120.

KofoID, C. A. 1907. Dinoflagellata of the San Diego Region, III. Descriptions of New Species. The University Press.

--- 1909. On Peridinium steinii Jörgensen, with a note on the nomenclature of the skeleton of the Peridinidae. Archiv. fur Protistenkunde 16: 25-47.

KoKINOS, J. P., and D. M. ANDERSON. 1995. Morphological development of resting cysts in cultures of the marine dinoflagellate Lingulodinium polyedrum $(=L$. machaerophorum). Palynology 19: 143-166.

Lebour, M. V. 1922. Plymouth Peridinians. J. Mar. Biol. Ass., Plymouth 12.

MAtsuOKA, K. 1988. Cyst-theca relationships in the Diplopsalid group (Peridiniales, Dinophyceae). Review of Paleobotany and Palynology 56: 95-122.

NAUSTVOLL, L. J. 2000. Prey size spectra and food preferences in thecate heterotrophic dinoflagellates. Phycologia 39: 187-198.

Nunn, G. B., B. F. Theisen, B. Christensen, and P. ArCtander. 1996. Simplicitycorrelated size growth of the nuclear 28S ribosomal RNA D3 expansion segment in the crustacean order Isopoda. Journal of Molecular Evolution 42: 211-223.

PAUlSEN, O. 1931. Études sur le microplancton de la mer d'Alboran. Trabajos del Instituto Espanol De Oceanografia, Madrid 4: 1-108.

Posada, D., and K. A. Crandall. 1998. MODELTEST: testing the model of DNA substitution. Bioinformatics 14: 817-818.

Pouchet, G. 1883. Contribution a l'histoir des Cilio-flagellates. Journ. Anat. Physiol. 19: 399-455.

Rehnstam-Holm, A. S., A. GodHE, and D. M. ANDERSON. 2002. Molecular studies of Dinophysis (Dinophyceae) species from Sweden and North America. Phycologia 41: 348-357.

RonQuist, F., and J. P. HuElSENBECK. 2003. MrBayes 3: Bayesian phylogenetic inference under mixed models. Bioinformatics 19: 1572-1574. 
Saldarriaga, J. F., F. J. R. TAYlor, T. Cavalier-Smith, S. MEnden-Deuer, and P. J. KEELING. 2004. Molecular data and the evolutionary history of the dinoflagellates. European Journal of Protistology 40: 85-111.

SAntos, S. R., R. A. KInZIE, K. SAKAI, and M. A. Coffroth. 2003. Molecular Characterization of Nuclear Small Subunit (18S)-rDNA Pseudogenes in a Symbiotic Dinoflagellate (Symbiodinium, Dinophyta). Journal of Eukaryotic Microbiology 50: 417-421.

Scholin, C. A., D. M. ANDERSON, and M. L. Sogin. 1993. Two distinct small-subunit ribosomal RNA genes in the North American toxic dinoflagellate Alexandrium fundyense (Dinophyceae). Journal of Phycology 29: 209-216.

Scholin, C. A., M. Herzog, M. Sogin, and D. M. Anderson. 1994. Identification of group- and strain-specific genetic markers for globally distributed Alexandrium (Dinophyceae). 2. Sequence analysis of a fragment of the LSU rRNA gene. Journal of Phycology 30: 999-1011.

SEBASTIÁN, C. R., and C. O'RYAN. 2001. Single-cell sequencing of dinoflagellate (Dinophyceae) nuclear ribosomal genes. Molecular Ecology Notes 1: 329-331.

SwOFFORD, D. L. 2002. PAUP*: Phylogenetic Analysis Using Parsimony (*and other methods), Version 4.0b10. Sinauer.

TAYLOR, F. J. R. 1976. Dinoflagellates from the International Indian Ocean Expedition: A report on material collected by the R.V. "Anton Bruun" 1963-1964. E. Schweizerbart'sche Verlagsbuchhandlung.

---. 2004. Illumination or confusion? Dinoflagellate molecular phylogenetic data viewed from a primarily morphological standpoint. Phycological Research 52: 308-324.

vON STOCH, H. A. 1964. Zum problem der sexuellen fortpflanzung in der Peridineengattung Ceratium. Helgoländer wissenschaftliche Meeresuntersuchungen 10: 140-151.

---. 1973. Observations on vegetative reproduction and sexual life cycles of two freshwater dinoflagellates, Gymnodinium pseudopalustre Schiller and Woloszynskia apiculata sp. nov. Br. Phycol. J. 8: 105-134.

WALL, D., and B. DALE. 1968. Modern dinoflagellate cysts and evolution of the Peridiniales. Micropaleontology 14: 265-304. 
YAMAGUCHI, A., and T. HoRIGUCHI. 2005. Molecular phylogenetic study of the heterotrophic dinoflagellate genus Protoperidinium (Dinophyceae) inferred from small subunit rRNA gene sequences. Phycological Research 53: 30-42.

YeUnG, P. K. K., K. F. KonG, F. T. W. WonG, and J. T. Y. WonG. 1996. Sequence data for two large-subunit rRNA genes from an Asian strain of Alexandrium catenella. Applied and Environmental Microbiology 62: 4199-4201. 


\section{Chapter 5}

High intragenomic variability in large subunit ribosomal DNA genes in the heterotrophic dinoflagellates Protoperidinium, Diplopsalis, and Preperidinium (Dinophyceae) 


\begin{abstract}
Large-subunit ribosomal DNA (LSU rDNA) gene sequences are frequently used to infer the phylogeny of organisms. The many copies of the LSU rDNA found in the genome are thought to be kept homogenous by concerted evolution. In this study, we found and characterized the intragenomic diversity in the D1-D6 region of the LSU rDNA gene in eight species of thecate, heterotrophic dinoflagellates using single-cell PCR, cloning, and sequencing of many clones. For each species, the clone library was usually comprised of one highly represented copy and many unique sequences. Sequence differences were primarily characterized by single base pair substitutions, single base pair insertion/deletions (indels), and/or large indels. Phylogenetic analysis of all clones gave strong support for monophyly of the polymorphic copies of each species, and recovered the same species tree as an analysis using just one sequence per species. Analysis of LSU rDNA gene expression in three species by RT-PCR indicated that copies with fewer substitutions and fewer and smaller indels are expressed, and that $50 \%$ or more of the copies are pseudogenes. High intraspecific and intraindividual LSU rDNA sequence variability could lead to inaccurate species phylogenies and over-estimation of species diversity in environmental sequencing studies.
\end{abstract}

Keywords: heterotrophic dinoflagellates; gene family; intraspecific variability; LSU rDNA; sequence polymorphism; pseudogene 


\section{INTRODUCTION}

Protoperidinium Bergh is a cosmopolitan genus of marine, heterotrophic dinoflagellates, of which there are more than 200 species (Balech 1974). Protoperidinium spp. occupy an important ecological niche as raptorial, and often selective, feeders on large phytoplankton and protistan prey (Gaines and Taylor 1984; Jacobson and Anderson 1986; Naustvoll 2000). Although an estimated $50 \%$ of dinoflagellates are heterotrophic or mixotrophic (Gaines and Elbrächter 1987), these groups are relatively underrepresented in molecular phylogenetic studies. Thecate heterotrophic dinoflagellates, in particular, have been poorly sampled.

Large-subunit ribosomal DNA (LSU rDNA) gene sequences are frequently used to infer the phylogeny of organisms. The LSU rDNA gene contains both highly variable and highly conserved regions, making it useful for comparisons of organisms from a range of taxonomic levels. Known to be tandemly arrayed in hundreds to thousands of copies in most organisms, the LSU rDNA gene is a relatively easy target for amplification. Additionally, the many copies of ribosomal genes within a species are thought to be kept homogenous by concerted evolution, a process of non-independent evolution of repetitive DNA sequences leading to greater similarity of sequences in a gene family within a species than between species (Dover 1982). Concerted evolution, generally accepted as a universal phenomenon (Liao 1999) works by various mechanisms of DNA repair and replication, including unequal crossing-over among tandemly arranged genes in the same gene family, gene conversion (Arnheim et al. 1980), and reciprocal exchange (Aguilera and Klein 1989).

In recent years, however, workers have begun to realize the extent of both intraspecific and intraindividual variability in ribosomal genes. Examples of intragenomic variability in rDNA have been found in a range of organisms, including in the variable internal transcribed spacer region (ITS) of cactus (Hartmann et al. 2001) and pinyon pine (Gernandt et al. 2001), the small subunit (SSU) rDNA of Skeletonema spp. diatoms 
(Alverson and Kolnick 2005), Acropora spp. corals (Márquez et al. 2003), and the dinoflagellates Symbiodinium spp. (Santos et al. 2003) and Alexandrium fundyense (Scholin et al. 1993), and in the LSU rDNA of dinoflagellates including Alexandrium catenella (Yeung et al. 1996), and Dinophysis acuminata (Rehnstam-Holm et al. 2002). Sequence polymorphism across the entire rDNA cistron has been found in salmonid fish (Reed et al. 2000) and in humans (Brownell et al. 1983).

Intraspecific diversity in ribosomal genes has important implications for phylogenetic studies. Orthologous genes, which trace their ancestry to a speciation event, must be used for determining evolutionary species relationships. Paralogous genes, often difficult to distinguish from orthologs in large gene families, trace their ancestry to a duplication event. If sufficiently divergent paralogous genes are used in phylogenetic investigation, the result can be a tree that reflects the evolution of the gene sequence, but not of the species. Understanding the extent and type of intraspecific gene variability is thus critical for robust phylogenetic studies.

In this study, we characterized the intragenomic diversity in the D1-D6 region of the LSU rDNA gene in eight species of thecate, heterotrophic dinoflagellates, documenting extremely high variability within species, and even within a single cell. We investigated the phylogeny of the polymorphic copies, to determine whether the LSU rDNA gene remains an appropriate marker for phylogenetic investigation of these heterotrophic protists. Examination of LSU rDNA gene expression was conducted to determine whether polymorphic copies were functional genes or non-functional pseudogenes.

\section{MATERIALS AND METHODS}

Isolation and Culturing

\section{Protoperidinium culturing}

Six Protoperidinium species and two diplopsalid species were isolated from sites around the North Atlantic, including off the coast of Massachusetts, in the Gulf of Mexico, 
Florida, and from the southwestern coast of Ireland. Five of these Protoperidinium species and Diplopsalis lenticula Bergh were brought into culture, and the other two species were studied using specimens isolated from the field (Table 1).

Protoperidinium spp. and D. lenticula were grown in $0.2 \mu \mathrm{m}$-filtered, Teflon-autoclaved seawater from Vineyard Sound ( $30 \mathrm{psu}$, or amended to $35 \mathrm{psu}$ by evaporation) and fed appropriate phytoplankton food species (Table 1). Cultures were maintained at $15{ }^{\circ} \mathrm{C}$ under low light (ca. $50 \mu \mathrm{mol}$ photon $\mathrm{m}^{-2} \mathrm{sec}^{-1}$ ) on a $14 \mathrm{~h}: 10 \mathrm{~h}$ light:dark cycle in $70 \mathrm{~mL}$ untreated tissue culture flasks (Falcon 353009) that were rotated on a plankton wheel at 1-2 rpm. Cultures were transferred every 4 to 5 days by pouring approximately twothirds the volume of the old culture into a new flask containing fresh sterile seawater and phytoplankton prey.

\section{Phytoplankton culturing}

Autotrophic dinoflagellate cultures were maintained at $15^{\circ} \mathrm{C}$ or $20^{\circ} \mathrm{C}$ in tubes with 25 $\mathrm{mL}$ of $\mathrm{f} / 2$ nutrient medium minus silicate (Guillard 1975), except for Lingulodinium polyedrum (Stein) Dodge (GPES 22) which was grown in ES medium (Kokinos and Anderson 1995). Diatom cultures (CCMP 356 and CCMP 158) were maintained in tubes with $25 \mathrm{~mL}$ of $\mathrm{f} / 2$ nutrient medium plus silicate at $15^{\circ} \mathrm{C}$. All prey cultures were kept at a photon flux density of ca. $100 \mu \mathrm{mol} \mathrm{m}^{-2} \mathrm{~s}^{-1}$, on a $14 \mathrm{~h}: 10 \mathrm{~h}$ light:dark cycle.

\section{Species Identification}

Morphological species identification of cultured Protoperidinium species and D. lenticula was confirmed by analysis of thecal plate structure using scanning electron microscopy (SEM) or by epifluorescence microscopy of cells stained with Calcofluor White MR2 (Polysciences, Warrington, PA). Species not brought in to culture were identified by light microscopy. Individual live cells were isolated by micropipette from field samples, examined for shape, size and thecal plate morphology on a Zeiss Axiovert S100 light microscope at 100-200X and photographed using a Sony Exwave HAD 3CCD color 


\begin{tabular}{|c|c|c|c|c|}
\hline Species & $\begin{array}{l}\text { Culture } \\
\text { Designation }\end{array}$ & $\begin{array}{c}\text { Clonal (C)/ } \\
\text { Unialgal (U) } \\
\text { / Field (F) }\end{array}$ & Origin & $\begin{array}{l}\text { Food } \\
\text { species }\end{array}$ \\
\hline $\begin{array}{l}\text { Diplopsalis lenticula } \\
\text { Bergh }\end{array}$ & M2 & U & Gulf of Mexico, FL & $\mathrm{Db}, \mathrm{Ca}$ \\
\hline $\begin{array}{l}\text { Preperidinium meunerii } \\
\text { (Pavillard) Elbrächter }\end{array}$ & $\mathrm{n} / \mathrm{a}$ & $\mathrm{F}$ & Salt Pond, MA & $\mathrm{n} / \mathrm{a}$ \\
\hline $\begin{array}{l}\text { Protoperidinium conicoides } \\
\quad \text { (Paulsen) Balech }\end{array}$ & $\mathrm{n} / \mathrm{a}$ & $\mathrm{F}$ & Salt Pond, MA & $\mathrm{n} / \mathrm{a}$ \\
\hline $\begin{array}{l}\text { Protoperidinium crassipes } \\
\text { (Kofoid) Balech }\end{array}$ & M065-PC-Cl7 & $\mathrm{C}$ & Gulf of Mexico, FL & Lp \\
\hline $\begin{array}{l}\text { Protoperidinium depressum } \\
\text { (Bailey) Balech }\end{array}$ & PDIR1A-Cl1 & $\mathrm{C}$ & SW Coast of Ireland & $\mathrm{Db}, \mathrm{Ca}$ \\
\hline $\begin{array}{l}\text { Protoperidinium oblongum } \\
\quad \text { (Aurivillius) Parke and Dodge }\end{array}$ & $24 \mathrm{C}(5)-\mathrm{PO}-1$ & $\mathrm{C}$ & SW Coast of Ireland & $\mathrm{Db}, \mathrm{Ca}$ \\
\hline $\begin{array}{l}\text { Protoperidinium steidingerae } \\
\text { Balech }\end{array}$ & MV0923-PO-Cl7 & $\mathrm{C}$ & Vineyard Sound, MA & $\mathrm{Db}, \mathrm{Ca}$ \\
\hline $\begin{array}{l}\text { Protoperidinium sp. } 1 \\
\text { Bergh }\end{array}$ & M064-sm-1 & U & Gulf of Mexico, FL & $\mathrm{n} / \mathrm{a}$ \\
\hline
\end{tabular}

Table 1.

Isolation and culturing information for thecate heterotrophic dinoflagellates studied. Food species: $\mathrm{Db}=$ Ditylum brightwellii (West) Grunow, $\mathrm{Ca}=$ Chaetocerous affinis Lauder, Lp = Lingulodinium polyedrum (Stein) Dodge. 
video camera integrated with Scion Image 1.62 software. The remainder of the field sample was preserved with borate-buffered formalin (5\% final concentration) and species identification of the live cells was verified by Calcofluor White staining of cells of similar morphology from the preserved field sample.

\section{SEM}

Samples were preserved with borate-buffered formalin (5\% final concentration) and stored at $4{ }^{\circ} \mathrm{C}$ at least overnight. Subsamples were centrifuged, aspirated to $1 \mathrm{~mL}$, and brought up to $4 \mathrm{~mL}$ with filtered seawater. Several hundred Protoperidinium cells were separated from phytoplankton prey in the sample by micropipette isolation, deposited into $2 \mathrm{~mL}$ cryovials with $5 \%$ formalin in filtered seawater, and stored at $4{ }^{\circ} \mathrm{C}$ overnight. Samples were drawn down onto filters (Nucleopore track-etched membrane, $13 \mathrm{~mm}, 5$ $\mu \mathrm{m}$ pore size), and washed first with filtered seawater and then with distilled, deionized water to remove fixatives and salts. Samples were dehydrated in a series of ethanol washes of increasing concentration, critical point dried (Tousimis Samdri-780A), sputter coated with gold palladium (Tousimis Samsputter-28), and examined on a SEM (JEOL JSM-840).

\section{Calcofluor White}

Cultures and field samples were preserved with formalin ( $5 \%$ final concentration) and stored at $4^{\circ} \mathrm{C}$ until analysis. Thecal plate staining was done with Calcofluor White according to the method of Fritz and Triemer (1985). Subsamples of stained cells were examined at $100-200 \mathrm{X}$ on a Zeiss Axioskop microscope with a $100 \mathrm{~W}$ mercury lamp and a Zeiss \#2 filter set (excitation $365 \mathrm{~nm}$, emission $420 \mathrm{~nm}$ ). Images were taken with a Zeiss MC 100 digital camera system.

\section{Single-cell PCR amplification, cloning, and sequencing of LSU rDNA}

Single-cell PCR was used to amplify the target sequence as described in Gribble and Anderson (In press). Single Protoperidinium sp. cells were isolated from culture or field 
samples by micropipette, washed 2-3 times in sterile filtered seawater and 1-2 times in sterile DI water, and deposited individually into PCR tubes in approximately $10 \mu \mathrm{l}$ of sterile DI water. To enhance cell lysis, PCR tubes with isolated cells were frozen at $-80^{\circ}$ $\mathrm{C}$ overnight and just before PCR were subjected to a sonification ice bath at $40 \mathrm{~A}$ for approximately $30 \mathrm{sec}$.

The single cells were used directly as template to amplify approximately $1430 \mathrm{bp}$ of the LSU rDNA containing the variable domains D1-D6, using the primers D1R (Scholin et al. 1994) and 28-1483R (Daugbjerg et al. 2000). The $50 \mu \mathrm{L}$ PCR reaction mixture contained 2.5 units of $P f u$, a proofreading DNA polymerase (Stratagene, La Jolla, CA), 5 $\mu \mathrm{L} 10 \mathrm{X}$ buffer (1x final concentration), $0.3 \mu \mathrm{M}$ of each primer, and $200 \mu \mathrm{M}$ dNTPs (Takara, Shiga, Japan). Thermal cycling was conducted using an initial denaturation at $95^{\circ} \mathrm{C}$ for $5 \mathrm{~min}$., 30 cycles of $95^{\circ} \mathrm{C}$ for $1 \mathrm{~min}$., $50^{\circ} \mathrm{C}$ for one min., and $72^{\circ} \mathrm{C}$ for $2 \mathrm{~min}$., followed by a final elongation step of $72^{\circ} \mathrm{C}$ for $10 \mathrm{~min}$.

Between 25-30 $\mu \mathrm{L}$ of PCR product was run on a 1\% agarose gel. Positive bands were excised and the product purified and concentrated using a MinElute Gel Extraction Kit (Quiagen, Valencia, CA). For each species, between 3 and 6 purified PCR products, each from a single cell, were cloned separately using the Zero Blunt TOPO PCR Cloning Kit for Sequencing (Invitrogen, Carlsbad, CA). Primers T3, T7, and a species-specific internal primer (Gribble and Anderson In press) were used for sequencing between 12 and 89 clones for each species. Sequencing was done on an Applied Biosystems 3730XL capillary sequencer.

\section{rDNA gene expression}

To determine if all LSU rDNA sequences for a given species were functional, or if some were unexpressed pseudogenes, gene expression was examined in Protoperidinium oblongum (Aurivillius) Parke and Dodge, Protoperidinium steidingerae Balech, and Protoperidinium crassipes (Kofoid) Balech using reverse transcription PCR (RT-PCR). 
These three species were chosen as they had been shown to have relatively high levels of intraspecific diversity as measured by number of unique sequences, number of polymorphic sites, and/or number of indels.

Total RNA was extracted from between 1 and 50 Protoperidinium sp. cells using the Ambion RnAqueous MicroElute Kit. Immediately after elution of RNA, samples were treated twice with DNase $\left(37^{\circ} \mathrm{C}, 15 \mathrm{~min}\right.$.) provided with the kit to remove any contaminating DNA, followed by two treatments with DNase inactivation reagent. Reverse transcription of RNA to cDNA was according to the protocol accompanying SuperScript III (Invitrogen, Carlsbad, CA). Specific primers 28-1483R (Daugbjerg et al. 2000) or D3B (Nunn et al. 1996) were used for reverse transcription. Control reactions with no reverse transcriptase were always run to check for DNA contamination. After reverse transcription, samples were treated with RNase H (Invitrogen, Carlsbad, CA) to remove any RNA that might act as template in the subsequent PCR reactions. PCR reactions were carried out using the same reagent concentrations and cycle as described above, except with an annealing temperature of $55^{\circ} \mathrm{C}$ instead of $50^{\circ} \mathrm{C}$. Positive bands were excised, purified, cloned and sequenced as described above.

\section{Phylogenetic analysis}

Partial LSU rDNA sequences from Protoperidinium spp., Diplopsalis lenticula Bergh, and Preperidinium meunerii (Pavillard) Elbrächter were edited using Sequencher 4.5. Uncertain base calls were corrected by hand with reference to the sequence chromatograph. Edited sequences were aligned using Clustal $\mathrm{X}$, and resulting alignments were edited by hand in MacClade 4.07. Within a species, all sequences could be fully aligned. When sequences from multiple species were aligned, regions that could not be reliably aligned were excluded from analyses.

Pairwise differences were calculated using neighbor joining analysis (gaps treated as missing data) in PAUP 4.0b10 (Swofford 2002). Intraspecific pairwise differences were 
determined from alignments of all of the LSU rDNA gene sequences for a given species. Pairwise differences between species were calculated from an alignment of the most abundant sequence in the clone library for each species, excluding bases 554-662 which were too divergent to be aligned.

The numbers and sizes of insertions/deletions (indels) were determined by manual examination of alignments in MacClade 4.07. In those cases where multiple indels of different sizes overlapped in the same region, they were counted as a single indel, since they may have resulted from a single initial insertion or deletion that was subsequently expanded or reduced in other gene copies during replication. The number of indels reported may therefore be an underestimate of the number of independent insertion or deletion events. The number of polymorphic site across an alignment of intraspecific LSU rDNA sequences was determined using DnaSP 4.10.7 software (Rozas et al. 2003).

Neighbor joining analysis was used to create a phylogenetic tree of all 179 sequences from the eight heterotrophic dinoflagellates studied plus two outgroup sequences from Genbank using PAUP* 4.0b10 (Swofford 2002). Identical sequences within a species were represented by a single sequence in the phylogenetic analyses. Nucleotide positions 554-662 were too divergent to be aligned, and were excluded from the phylogenetic analysis, leaving a total of 1455 bases. Gaps were treated as missing data. Branch swapping was by tree-bisection-reconnection. Bootstrap support values were determined from 1000 replicates.

\section{Rarefaction analysis}

Rarefaction analysis was conducted to estimate whether the full diversity of LSU rDNA sequences had been sampled for each species. Rarefaction allows the calculation of sequence diversity for a given number of sampled clones. The number of clones sequenced for each sequence variant were input into Analytic Rarefaction 1.3 (Holland 
2003) to produce rarefaction curves showing the expected number of unique sequences that would be found with increasing levels of sampling effort for a given species.

\section{RESULTS}

Sequencing directly from PCR products, using either purified or unpurified products resulted in "messy" sequences, often with multiple peaks in the sequence chromatogram. When the PCR products were cloned and those clones were sequenced, multiple, diverse copies of the LSU rDNA were found, even within a single cell. The clone library for each species was usually comprised of one highly represented sequence and many unique sequences (Table 2). Within any given species, differences between sequences were characterized primarily by single base pair substitutions and indels ranging in size from 1 bp up to $179 \mathrm{bp}$ (e.g. Figure 1). In a single sequence from $P$. depressum, a microsatellite was inserted, with the bases TG repeated in tandem 10 times, interrupted by bases GG, and then repeated an additional 15 times. In all species, nucleotide substitutions and indels were scattered across the gene, with no apparent clustering in either more or less divergent domains.

The degree of intraspecific sequence diversity, quantified by pairwise differences between sequences and by the number of polymorphic sites in the alignment of sequences for a given species, varied among species (Table 2). Indels were not included in pairwise difference or polymorphic site analyses of intraspecific pairwise differences.

The lenticular dinoflagellates $D$. lenticula and Preperidinium meunerii, along with $P$. conicoides, had the lowest sequence diversities of the species studied, with mean intraspecific pairwise differences of $0.12 \%, 0.21 \%$, and $0.18 \%$, respectively. These species had relatively low percentages of polymorphic sites, with $1.0 \%$ polymorphic sites for Preperidinium meunerii and $1.2 \%$ for $P$. conicoides, although the percent polymorphic sites was slightly higher for $D$. lenticula, at 3.5\%. Preperidinium meunerii 
Figure 1.

Alignment of partial LSU rDNA sequences from a single clonal culture of Protoperidinium depressum (800-1000 bp). The library of 83 clones was created from six separate, single-cell PCR reactions. Sequences that represent two or more identical sequences are listed in bold. Sequence PDIR 44cl represents 44 identical clones from all six PCR reactions. 


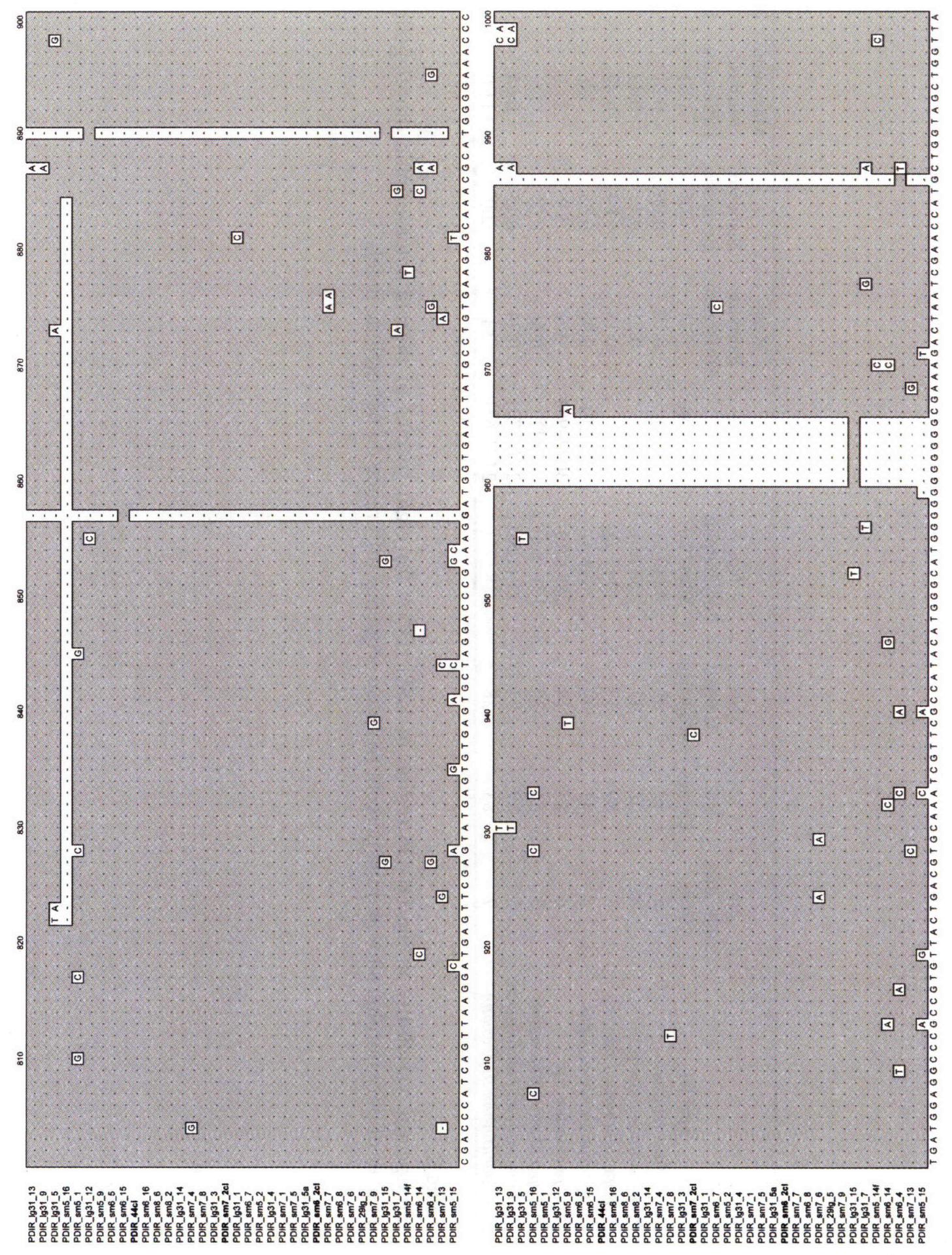

우 


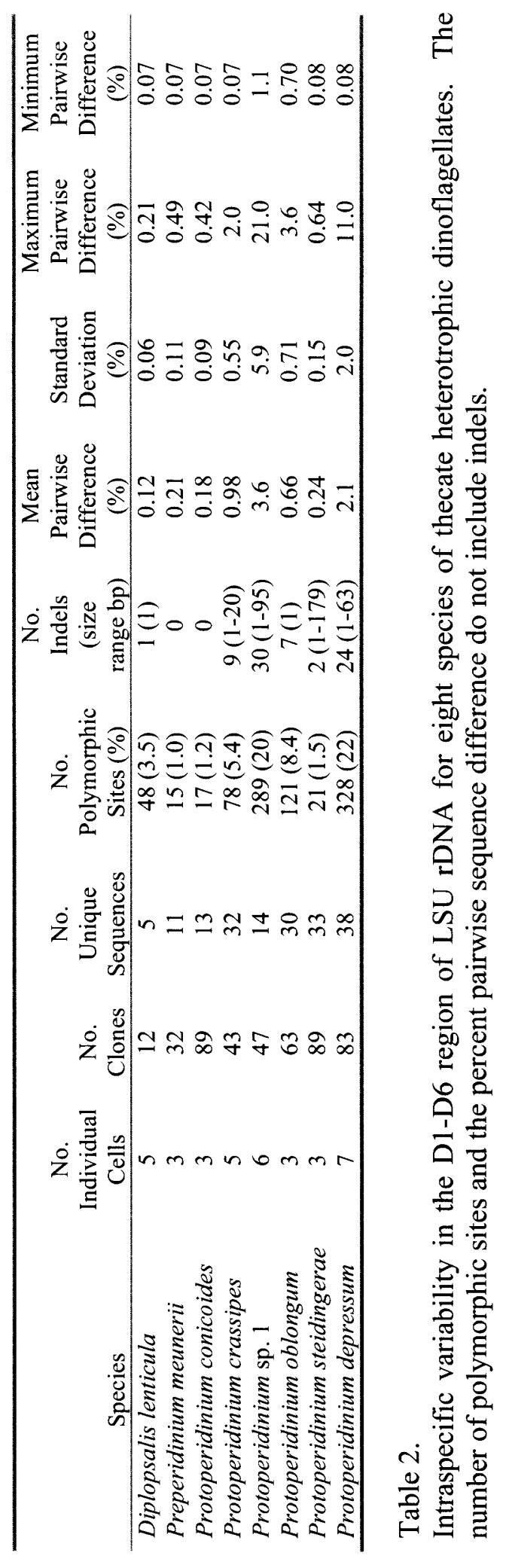

$\stackrel{0}{N}$ 
and $P$. conicoides sequences had no indels, and $D$. lenticula had only one single base pair indel.

Protoperidinium sp. 1 had the highest mean intraspecific pairwise difference (3.6\%), with a maximum pairwise difference between any two sequences of $21.0 \%$. Protoperidinium depressum and $P$. oblongum had relatively high mean pairwise differences and high numbers of polymorphic sites. Sequences from these species were characterized by many large indels. Protoperidinium steidingerae had relatively lower mean pairwise differences $(0.24 \%)$ and numbers of polymorphic sites $(1.5 \%)$, but contained a large indel of 179 bp. Protoperidinium crassipes had intermediate intraspecific sequence variability, with a mean pairwise difference of $0.98 \%, 5.4 \%$ polymorphic sites, and 9 indels up to 20 bp in length.

Rarefaction analysis indicated that we had not sampled the full diversity of LSU rDNA sequences for any species, despite sequencing between 12 and 89 clones for each species (Fig. 2). This analysis does not allow determination of the total number of sequence variants for a given species, however. Additional sampling would have to be done to better characterize all the different sequence variants within a given species.

Intraspecific sequence diversity, measured both by the number of unique sequences in the clone library for a given species and by the mean intraspecific pairwise difference was not dependent upon the number of clones sequenced for a given species (Fig. 3). Thus, variability in sequence diversity among species seems to be inherent, and is not due to differences in sampling effort.

The mean intraspecific LSU rDNA sequence variability was in all cases lower than the mean interspecific variability (Table 3). The maximum pairwise differences of Protoperidinium sp. $1(21.0 \%)$ and $P$. depressum (11.0\%) were approaching the interspecific differences between some species, and were higher than the differences 
Figure 2.

Rarefaction analysis of clone library from genomic DNA for each species, showing expected number of unique sequences for given number of clones sequenced. (A) Diplopsalis lenticula, (B) Preperidinium meunerii, (C) Protoperidinium conicoides, (D) Protoperidinium crassipes, (E) Protoperidinium sp. 1, (F) Protoperidinium oblongum, (G) Protoperidinium steidingerae, (H) Protoperidinium depressum 

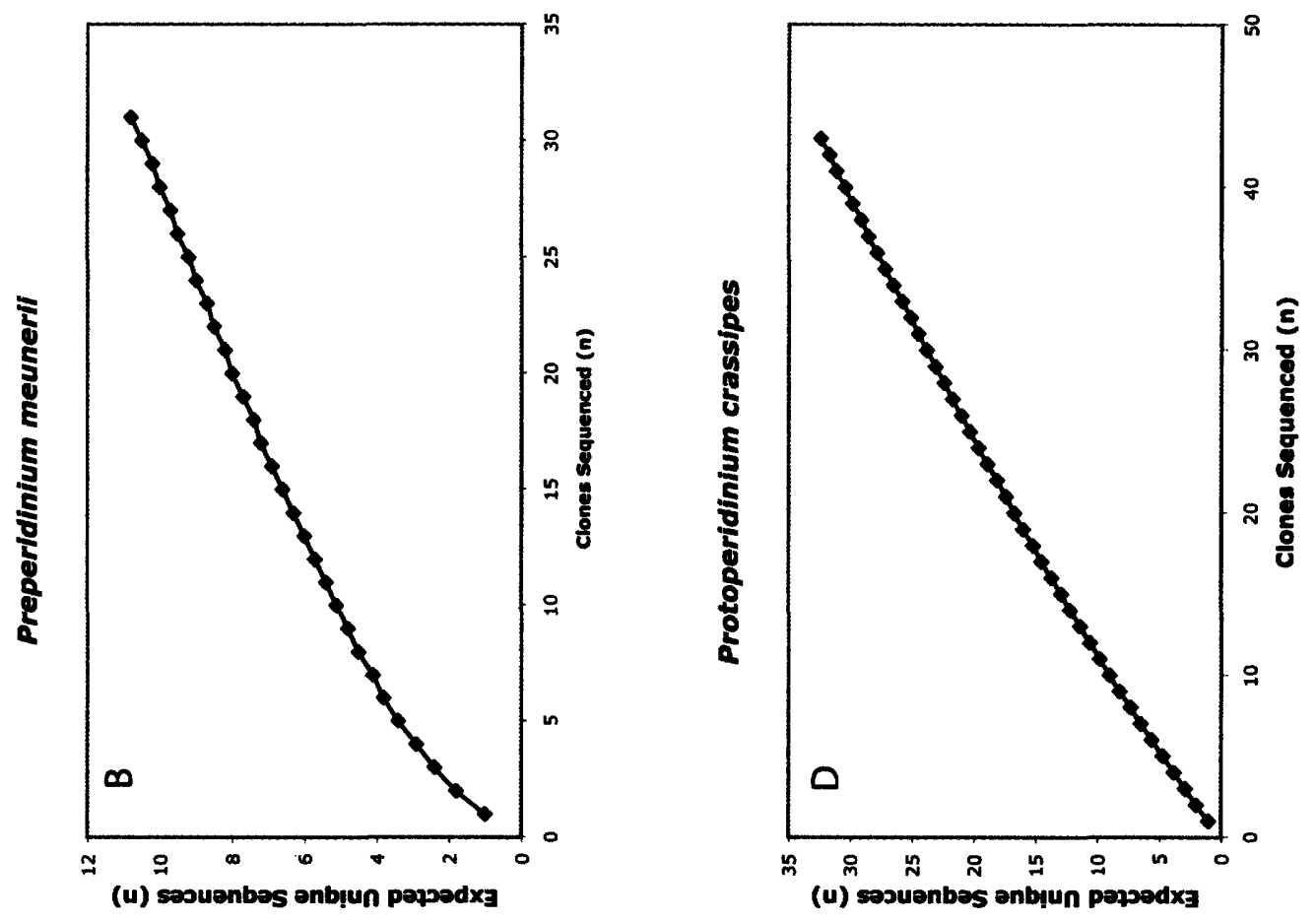

$\frac{m}{N}$
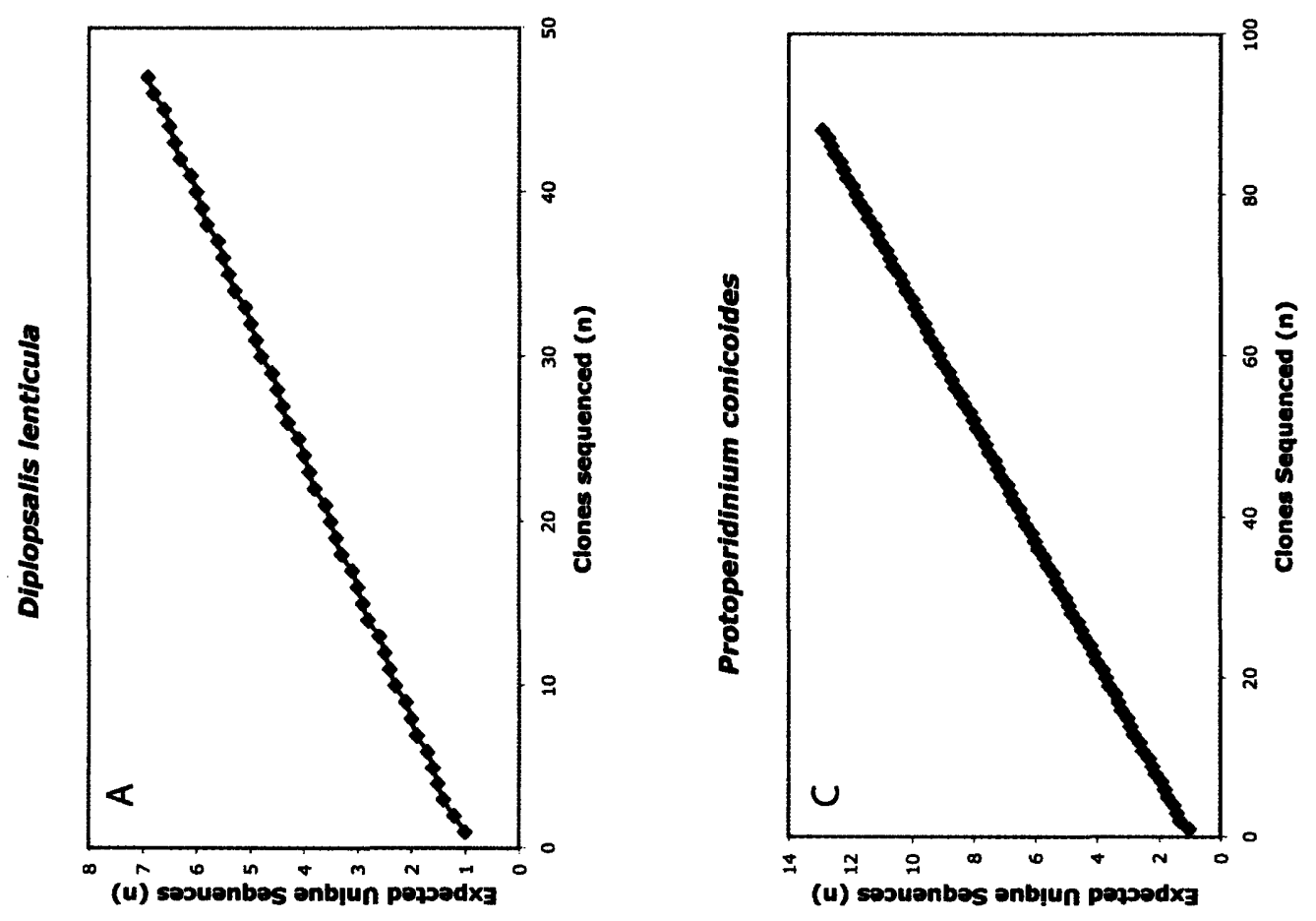

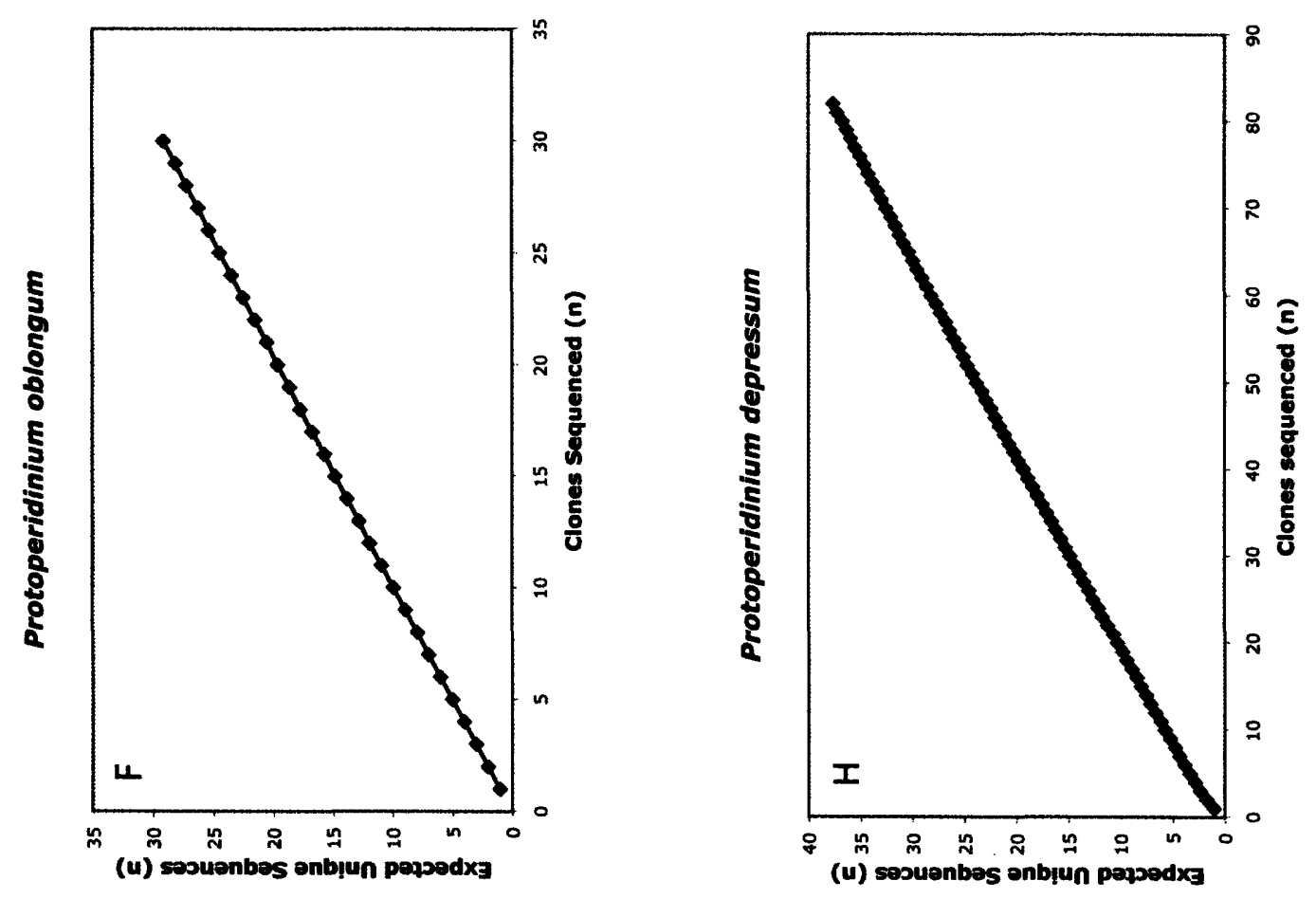

$\stackrel{\nabla}{N}$
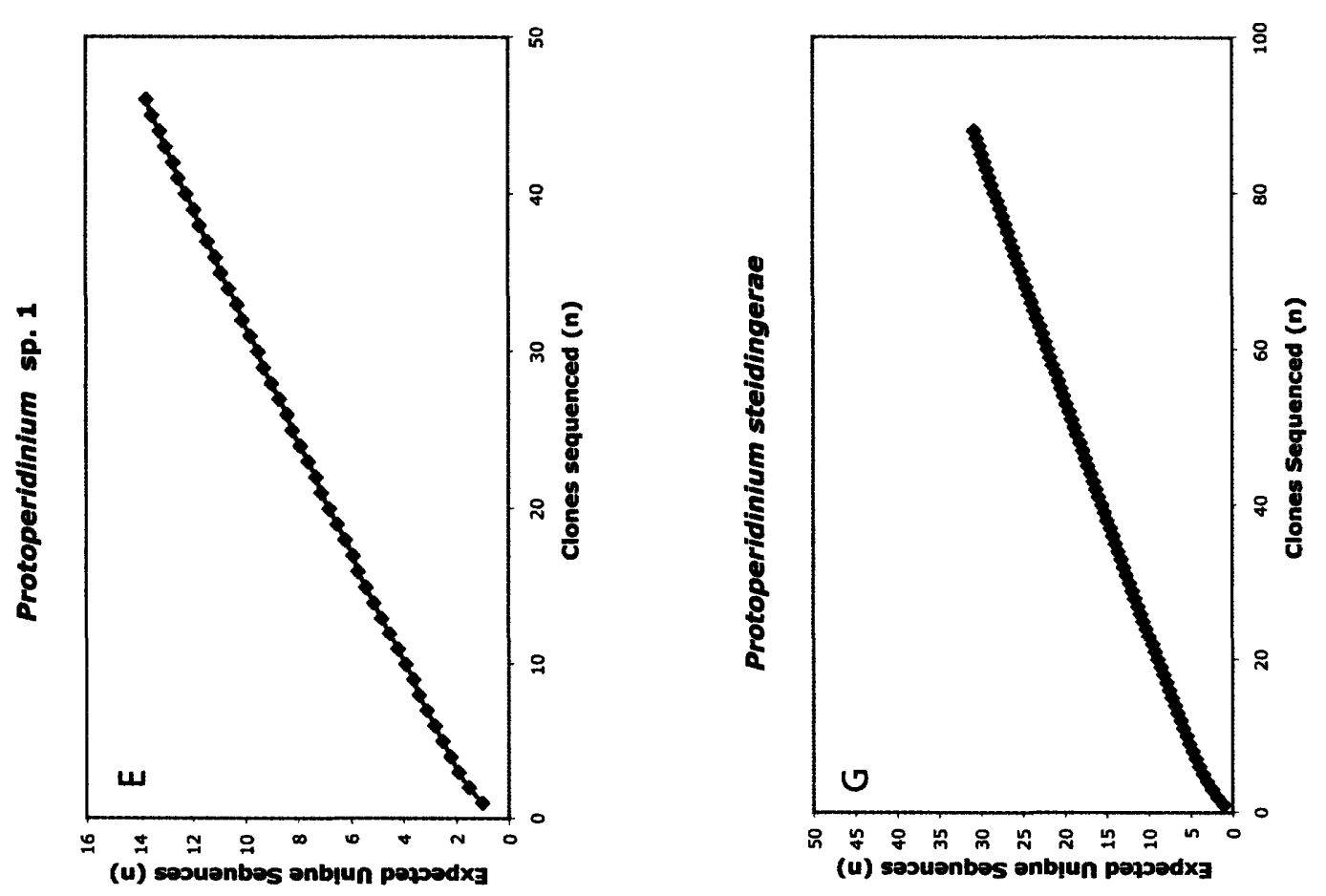
between closely related species like the diplopsalids $D$. lenticula and Preperidinium meunerii, and the Orthoperidinium species $P$. depressum and $P$. oblongum.

Despite the high variability within species, sequence variants for each species were monophyletic, a finding supported by high bootstrap values (Fig. 4). The level of sequence variability can be estimated by the lengths of the branches in the phylogenetic tree. Those species with similar levels of species diversity tend to be in the same clade. The diplopsalid species, which had very low intragenomic sequence diversity, were basal to the Protoperidinium species. The Protoperidinium split into two main clades. The first clade contained species of intermediate sequence diversity, including $P$. conicoides, Protoperidinium sp. 1, and $P$. crassipes, with $P$. conicoides branching as a sister group to Protoperidinium sp. 1, and P. crassipes. The second clade contained species of highest intraspecific diversity; $P$. depressum, $P$. oblongum, and $P$. steidingerae, with $P$. steidingerae branching separately from the more closely related $P$. depressum and $P$. oblongum.

\section{LSU rDNA gene expression}

The diversity of expressed LSU rDNA sequences was lower than the diversity of genomic sequences in each of the three species analyzed by RT-PCR (Table 4). Protoperidinium oblongum, for example, which had a mean pairwise difference of $0.66 \%$ among polymorphic sequences amplified from genomic DNA, exhibited a mean pairwise difference in expressed sequences of $0.14 \%$, with a maximum pairwise difference of $0.21 \%$. While 30 of $31(97 \%)$ of clones from genomic DNA were unique, only 4 out of $17(23 \%)$ of clones of expressed sequences were unique in P. oblongum. Additionally, there were no indels in expressed sequences of $P$. oblongum, compared with 7 single bp indels in clones from genomic DNA.

Protoperidinium crassipes and $P$. steidingerae expressed a larger portion of their complement of LSU rDNA genes than did P. oblongum. In P. crassipes, 15 out of 37 
Figure 3.

(A) Comparison of number of clones sequenced with mean pairwise difference (\%) and (B) number of clones sequenced with number of unique sequences found, for each of eight species analyzed. No relationship between cloning effort and observed intraspecific diversity was found $\left(\mathrm{r}^{2}<0.3\right.$ for regression analyses in both cases). 

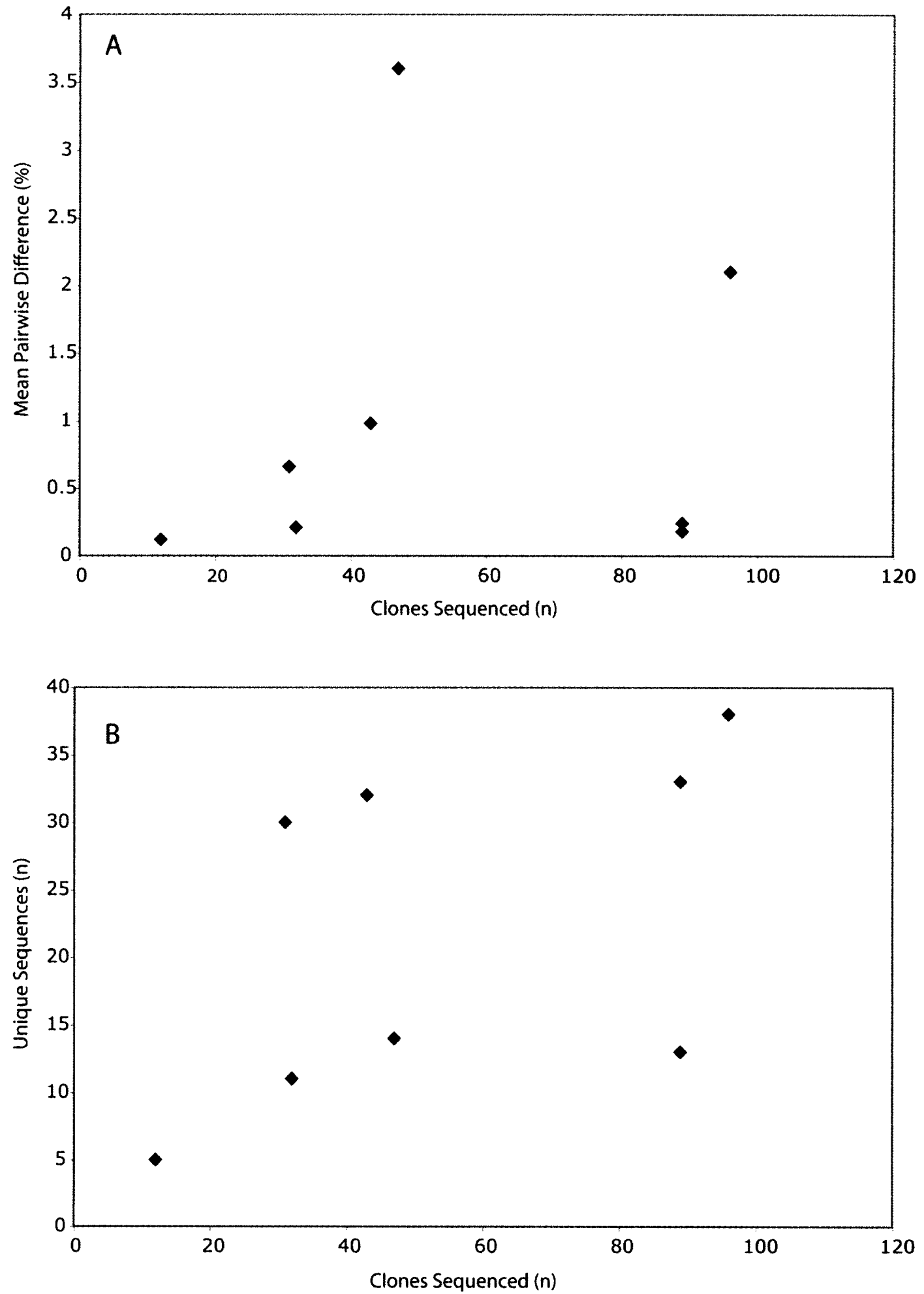


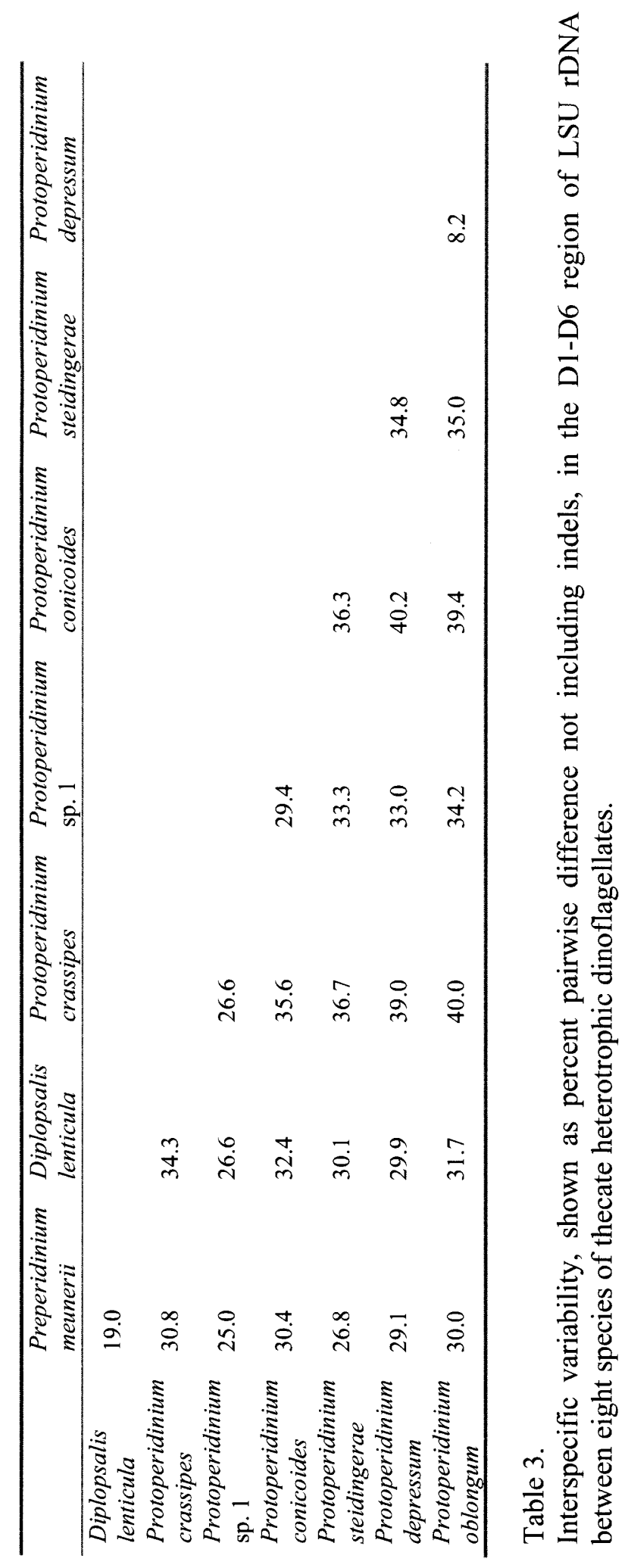


(41\%) clones of expressed sequences were unique, down from the 32 unique clones out of 43 total (74\%) in genomic clone libraries. Expressed sequences of $P$. crassipes had fewer polymorphic sites and no indels, compared with sequences from genomic DNA. Protoperidinium steidingerae expressed 16 unique sequences from 31 clones (51\%), up slightly from 33 unique out of 89 total clones from genomic DNA (39\%). The expressed sequences in $P$. steidingerae had approximately the same percent of polymorphic sites and smaller indel sizes than sequences from the genomic clone library.

Sequences found in RT-PCR overlapped with those from the clone libraries from genomic DNA for all three species. For $P$. crassipes, $13 \%$ of sequences from the genomic clone library overlapped with $27 \%$ of the sequences from RT-PCR. In $P$. oblongum, $3 \%$ of genomic sequences were identical to $25 \%$ of RT-PCR sequences, and in $P$. steidingerae, $9 \%$ of genomic sequences matched $18 \%$ of sequences from RT-PCR.

Results of analytic rarefaction analysis suggested that not all expressed copies of the LSU rDNA were sequenced for any of the three species. For $P$. crassipes, $P$. oblongum, and $P$. steidingerae the rarefaction curves did not reach a maximum or begin to level out (Fig. $5)$.

\section{DISCUSSION}

Thecate heterotrophic dinoflagellate species investigated here were found to have higher than expected intragenomic diversity in LSU rDNA sequences. The level of sequence diversity varied among species. Some, but not all, of the different copies are nonfunctional pseudogenes. These species appear to express more than one copy of the LSU rDNA, although the expressed sequences were generally less variable than the genomic copies.

Results of previous studies have indirectly indicated that Protoperidinium species might have high intraspecific rDNA sequence polymorphism. Reports of difficulties in direct 
Figure 4.

Neighbor joining tree of heterotrophic dinoflagellate phylogeny inferred from the D1-D6 region of LSU rDNA with Amphidinium steinii Lemmermann (Genbank accession AY455673) and Amphidinium carterae Hulburt (Genbank accession AY455669) as outgroups. Sequences used for each species were from clone libraries created from 3-6 separate single cell PCR reactions. Gaps were treated as missing data. Neighbor joining bootstrap support values from 1000 replicates are shown above the node. Bootstrap support values lower than $50 \%$ are not shown. Numbers at the ends of terminal nodes refer to the number of clones sharing the sequence represented by that node. 


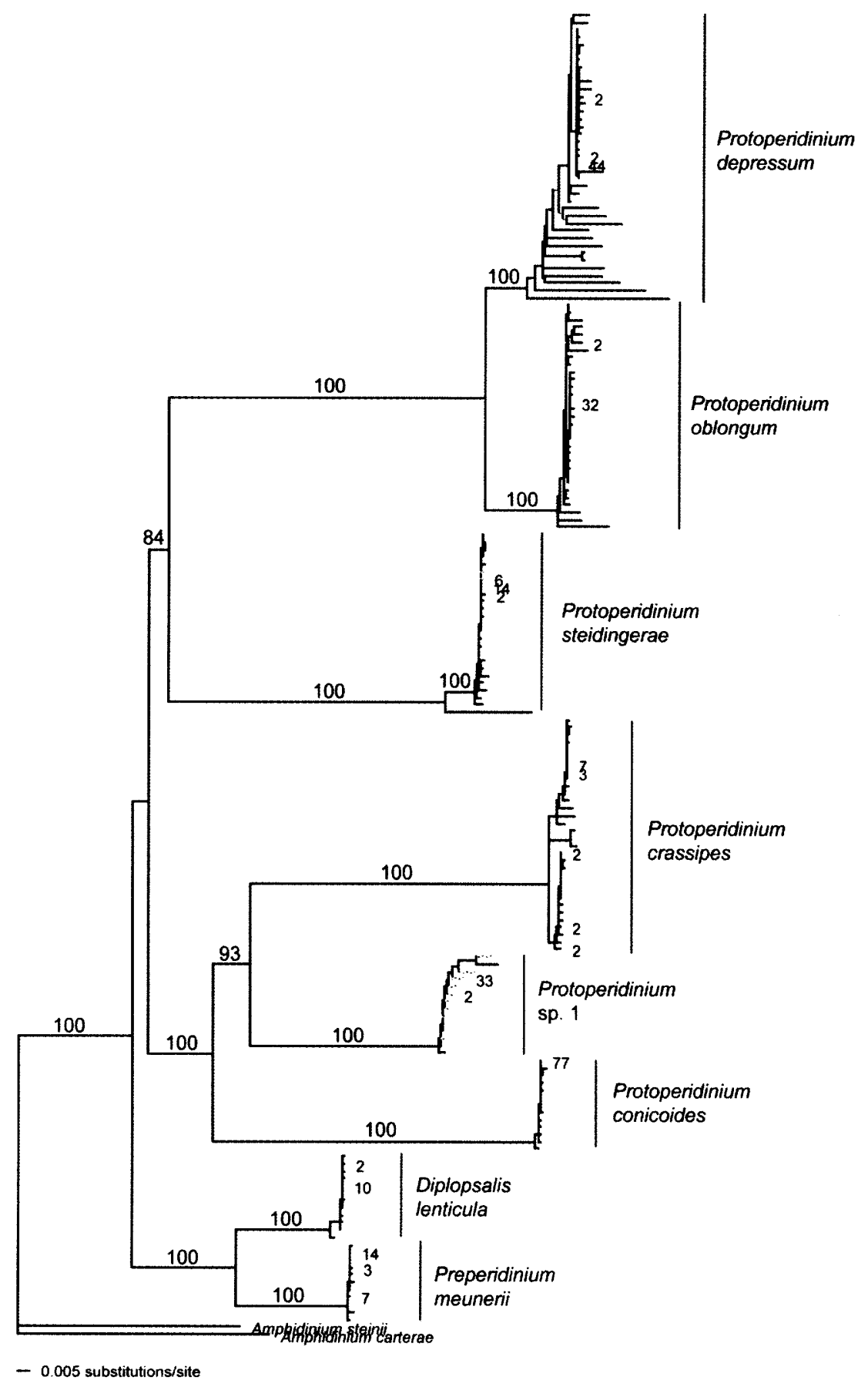




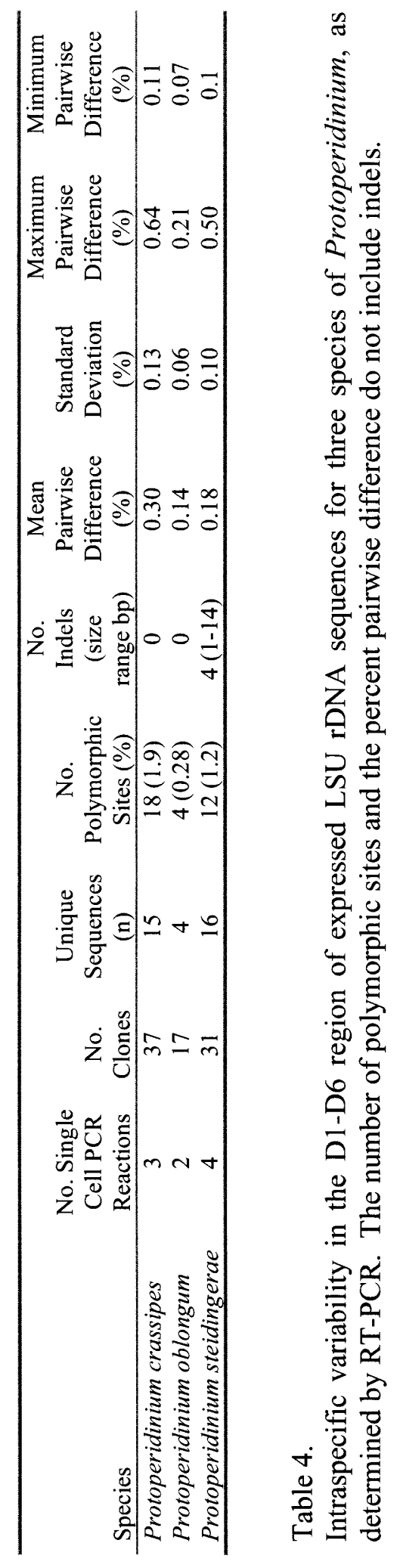


sequencing of PCR products of LSU rDNA genes from Protoperidinium spp. (e.g. Bolch 2001) are likely due to the high degree of intraspecific and intraindividual sequence diversity documented here. In an investigation of the phylogeny of the Protoperidinium inferred from the SSU rDNA, where sequencing was done directly from PCR products, a high sequence variability among conspecific individuals taken from the same field sample was reported (Yamaguchi and Horiguchi 2005). Sequencing cloned PCR products from a number of individuals and comparing those sequences would be required to determine if true intraspecific variability was observed, or if paralogous genes within the same species were differentially amplified in PCR.

Intraspecific heterogeneity in the ribosomal genes of a few dinoflagellate species has been reported previously (Scholin et al. 1993; Yeung et al. 1996; Rehnstam-Holm et al. 2002; Santos et al. 2003). In those cases, researchers generally found only one or two polymorphic copies, a much lower degree of intraspecific polymorphism than that discovered here. In the earlier studies, many fewer clones were sequenced, possibly accounting for some of the difference between our study and the previous research. Large sample sizes may be needed for accurate estimates of sequence diversity in a species.

The level of intraindividual sequence polymorphism seen here initially raised concern about the role of PCR error in artificially creating sequence diversity. Recombination of sequences in multigene families like rDNA genes can occur during PCR, resulting in hybrid sequences and causing an overestimate of sequence diversity. Such recombination combines already existing sequences however, and does not generate polymorphisms de novo. Although chimeric sequences were not apparent in the data, we could not rule out some level of PCR-induced recombination.

Error can also occur during PCR due to incorporation of the wrong nucleotide by the DNA polymerase during amplification. To minimize enzyme-mediated PCR error, we 
Figure 5.

Rarefaction analysis of clone library from expressed LSU rDNA from RT-PCR analysis for each species, showing expected number of unique sequences for given number of clones sequenced. (A) Protoperidinium crassipes, (B) Protoperidinium oblongum, (C) Protoperidinium steidingerae. 
Protoperidinium crassipes RT-PCR

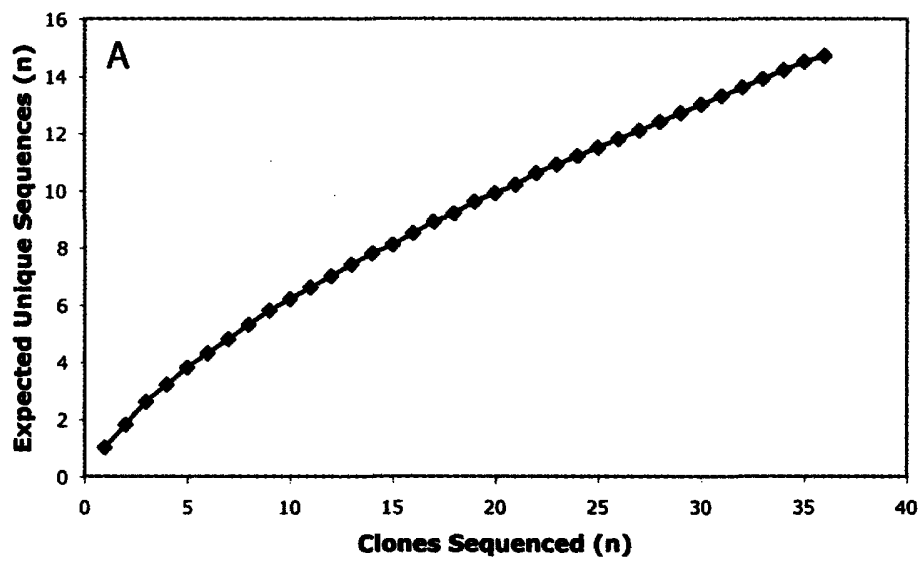

Protoperidinium oblongum RT-PCR

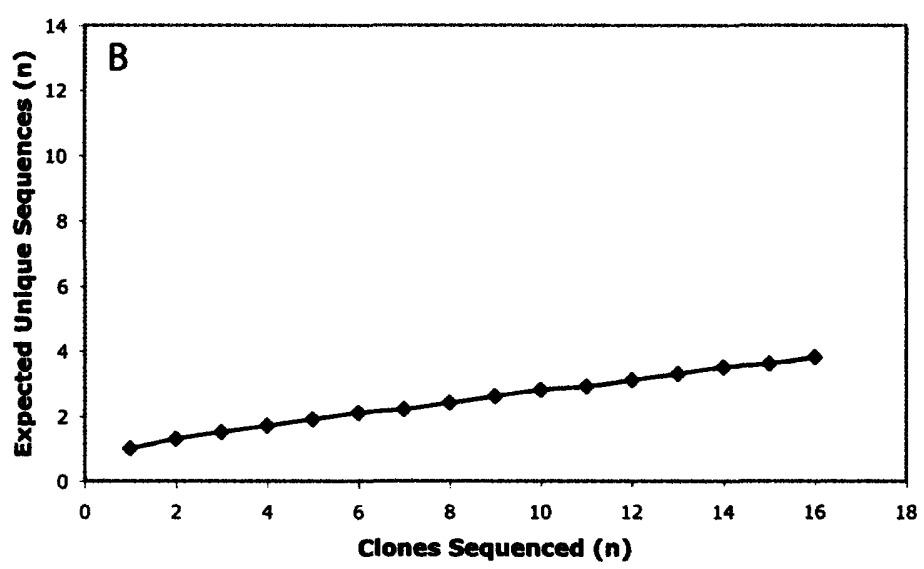

Protoperidinium steidingerae RT-PCR

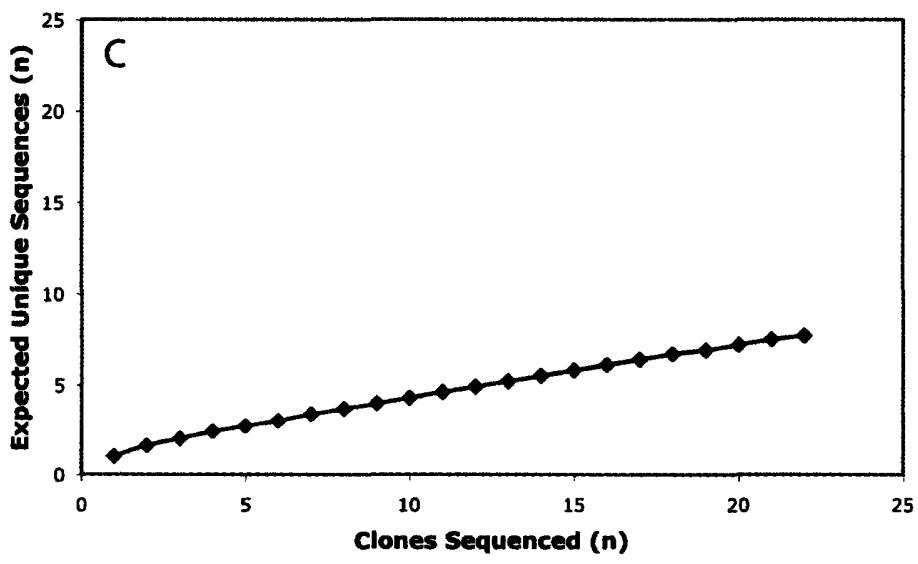


switched from Taq DNA polymerase, with an error rate estimated at $8.0 \times 10^{-6}$ errors $/ \mathrm{nt}$ (Cline et al. 1996) to $1.1 \times 10^{-4}$ errors/nt (Cariello et al. 1991; Barnes 1992) to the proofreading DNA polymerase, $P f u$, with an error rate of $1.3 \times 10^{-6}$ errors/nt (Cline et al. 1996). This change resulted in no appreciable difference in the level of intraindividual or intraspecific LSU rDNA polymorphism, indicating that the polymorphism was likely real, and not due to enzyme replication error during PCR. Thus, we felt that pooling data obtained with the two different enzymes was justified. Additionally, there was no difference in the degree of sequence polymorphism between PCR reactions conducted with DNA extracted from individual or multiple cells or from those done directly on isolated single cells without DNA extraction (data not shown), indicating that extreme PCR error due to our single-cell PCR method was not the cause of the high degree of intragenomic sequence diversity.

The match between sequences found in the genomic clone libraries and the RT-PCR clone libraries, ranging from $3 \%$ to $33 \%$ identity, provides another indication that the intragenomic sequence variability observed was all not due to PCR error. The same PCR errors would be unlikely to occur during separate PCR reactions run under different conditions.

PCR error cannot be discounted as a source of some variability, however. In all species, the lowest pairwise differences may be accounted for by PCR error, as they fall within the error range for $P f u$ polymerase. In the case of the species with lowest rates of difference, $D$. lenticula, Preperidinium meunerii, and $P$. conicoides, PCR error could account for the majority of polymorphic sequences. Based on the current work, there appears to be significant differences among species in the level of intraspecific variability in the LSU rDNA. Mean pairwise difference was 30 times greater in $P$. crassipes than in Preperidinium meunerii, for example. Gene duplication and concerted evolution appear to be acting at different rates in various clades of dinoflagellates. 
Intragenomic sequence variability will accumulate if the rate of gene conversion is lower than the rate of mutation, or if concerted evolution is slower than speciation. High intraspecific sequence variability may also exist if a species is in a "transitional state" of concerted evolution (Elder and Turner 1995). In the heterotrophic dinoflagellates examined here, greater sequence similarity of the LSU rDNA within a species than between species implies a mechanism to maintain sequence homogeneity. The high degree of intraspecific sequence polymorphism indicates that concerted evolution is acting more slowly than mutations are occurring in the Protoperidinium spp. examined, however. Nothing is known about the chromosomal location of the ribosomal genes in dinoflagellates, but given the large DNA content (3-250 pg/cell) and many chromosomes in dinoflagellates (e.g. 143 chromosomes in Alexandrium fundyense, reviewed in Hackett et al. 2004), it is likely that they bear rDNA loci on multiple and possibly nonhomologous chromosomes, limiting the effectiveness of concerted evolution. Intrachromosomal homogenization of repeated sequences is faster than interchromosomal recombination. Additionally, effective homogenization of dispersed genes by gene conversion, i.e., the non-reciprocal exchange of genetic information between similar sequences, is only effective when the number of dispersed genes is small (reviewed by Liao 1999). Concerted evolution does not appear to be slower than speciation, however, since divergent paralogs were not found. Differences between mutation rates and DNA repair rates can also lead to an accumulation of sequence variants in genes with multiple copies. Our results do not allow us to distinguish between the possible causes of the observed intraspecific variability.

Interspecific LSU rDNA sequence diversity was greater than intraspecific diversity, and in phylogenetic analysis the sequences for each species group together as a single clade of apparently paralogous genes. The phylogeny created from all sequenced clones has the same species topology as does the phylogeny created using a single sequence for each species (Gribble and Anderson In press). Care must be used in employing ribosomal genes as phylogenetic markers, however, as the ability to distinguish between paralogs 
and orthologs becomes difficult with increasing sequence polymorphism. As more closely related species are sequenced, or attempts are made to investigate cryptic species, divergent paralogs might be revealed, and use of the LSU rDNA in phylogenetic reconstruction may become more complicated.

Scattering of changes through both variable and conserved regions of the LSU rDNA in the heterotrophic dinoflagellates examined initially seemed to indicate that most sequences might not be functional. RT-PCR confirmed that the diversity of sequences in a given species was made up of both pseudogenes and expressed sequences. The expressed sequences in $P$. crassipes, $P$. oblongum, and $P$. steidingerae were less diverse than were the pseudogenes in these species, and generally had fewer and smaller indels. Because rRNAs are structural molecules that must be abundant for protein translation and cell function, it could be deleterious to simultaneously express heterogeneous rRNAs. On the other hand, expression of more than one version of the LSU rDNA could be beneficial, perhaps allowing adaptability to changing environmental conditions.

\section{CONCLUSIONS}

The results of this study have important implications for environmental sequencing studies, in which DNA extracted directly from environmental samples is amplified by PCR and used to create clone libraries. Such projects may greatly overestimate the species diversity in samples if unique phylotypes are assumed to be individual species. In this study, we found pairwise sequence differences of up to $21.0 \%$, not including differences due to indels, within a single culture. This level of sequence variability could easily be characterized as having been derived from separate species in environmental sequencing studies, in which the sequence difference for defining separate species is often about 3\% (e.g. Venter et al. 2004).

These results indicate that polymorphism of ribosomal genes may be greater and more widespread among the dinoflagellates than is currently realized, and provide evidence 
that the degree of intragenomic variability is not uniform across all dinoflagellates. Cloning and sequencing higher numbers of clones of PCR products from additional strains of the heterotrophic species studied here and from other autotrophic dinoflagellates would establish whether there is a significant difference in the level of intraspecific sequence polymorphism among various phylogenetic lineages of dinoflagellates. Finally, although ribosomal genes have long been standard tools in molecular phylogenetic investigations, our findings illustrate the need for thorough investigation of the genes chosen for inference of species phylogeny, as the evolution of the chosen gene may not perfectly mirror the evolution of the species of interest.

\section{ACKNOWLEDGEMENTS}

Thank you to the Marine Institute of Ireland, Trish Blum of the Mote Marine Laboratory, Florida, and David Kulis and Kenneth Houtler of the Woods Hole Oceanographic Institution for sample collection. Thanks to Malte Elbrächter for assistance with identification of $P$. steidingerae. Funding for this project came from the Comer Foundation, the Cove Point Foundation, and National Science Foundation grant OCE0136861.

\section{REFERENCES}

AGUILERA, A., and H. L. KLEIN. 1989. Yeast interchromosomal recombination: Long gene conversion tracts are preferentially associated with reciprocal exchange and require the $R A D 1$ and $R A D 3$ gene products. Genetics 123: 683-694.

AlVERSON, A. J., and L. KOLNICK. 2005. Intragenomic nucleotide polymorphism among small subunit (18S) rDNA paralogs in the diatom genus Skeletonema (Bacillariophyta). Journal of Phycology 41: 1248-1257.

ARnheim, N., M. Krystal, R. SchMickel, G. Wilson, O. Ryder, and E. ZiMMER. 1980. Molecular evidence for exchanges among ribosomal genes on nonhomologous chromosomes in man and apes. Proceedings of the National Academy of Sciences, USA 77: 7323-7327. 
Balech, E. 1974. El genero Protoperidinium Bergh, 1881 (Peridinium Ehrenberg, 1831, Partim). Revista del Museo Argentino de Ciencias Naturales "Bernardino Rivadavia" e Instituto Nacional de Investigacion de las Ciencias Naturales 4: 179.

BARNES, W. M. 1992. The fidelity of Taq polymerase catalyzing PCR is improved by an N-terminal deletion. Gene 112: 29-35.

BoLCH, C. J. S. 2001. PCR protocols for genetic identification of dinoflagellates directly from single cysts and plankton cells. Phycologia 40: 162-167.

Brownell, E., M. Krystal, and N. ARNHEIM. 1983. Structure and evolution of human and African ape rDNA pseudogenes. Molecular Biology and Evolution 1: 29-37.

CARIEllo, N. F., J. A. Swenberg, and T. R. SKOPEK. 1991. Fidelity of Thermococcus litoralis DNA polymerase (Vent) in PCR determined by denaturing gradient gelelectrophoresis. Nucleic Acids Research 19: 4193-4198.

Cline, J., J. C. BRaman, and H. H. Hogrefe. 1996. PCR fidelity of $P f u$ DNA polymerase and other thermostable DNA polymerases. Nucleic Acids Research 24: 3546-3551.

DaugbJerg, N., G. HANSEN, J. LARSEN, and Ø. Moestrup. 2000. Phylogeny of some of the major genera of dinoflagellates based on ultrastructure and partial LSU rDNA sequence data, including the erection of three new genera of unarmoured dinoflagellates. Phycologia 39: 302-317.

DOVER, G. 1982. Molecular drive: a cohesive mode of species evolution. Nature 299: 111-116.

ELDER, J., JOHN, F., and B. J. TURNER. 1995. Concerted evolution of repetitive DNA sequences in eukaryote. The Quarterly Review of Biology 70: 297-320.

FRITZ, L., and R. E. TRIEMER. 1985. A rapid simple technique utilizing Calcofluor white M2R for the visualization of dinoflagellate thecal plates. Journal of Phycology 21: 662-664.

GAINES, G., and M. ELBRÄCHTER. 1987. Heterotrophic nutrition, p. 225-268. In F. J. R. Taylor [ed.], The Biology of Dinoflagellates. Botanical Monographs. Blackwell Scientific Publications. 
GAINES, G., and F. J. R. TAYLOR. 1984. Extracellular digestion in marine dinoflagellates. Journal of Plankton Research 6: 1057-1062.

Gernandt, D. S., A. Liston, and D. Piñero. 2001. Variation in the nrDNA ITS of Pinus subsection Cembroides: Implications for molecular systematic studies of pine species complexes. Molecular Phylogenetics and Evolution 21: 449-467.

GRIBBLE, K. E., and D. M. ANDERSON. In press. Molecular phylogeny of the heterotrophic dinoflagellates, Protoperidinium, Diplopsalis, and Preperidinium (Dinophyceae), inferred from LSU ribosomal DNA. Journal of Phycology.

GuILLARD, R. R. L. 1975. Culture of phytoplankton for feeding marine invertebrates. In W. L. Smith and M. H. Chanley [eds.], Culture of Marine Invertebrates. Plenum Publishing Corporation.

Hackett, J. D., D. M. Anderson, D. L. Erdner, and D. Bhattacharya. 2004. Dinoflagellates: A remarkable evolutionary experiment. American Journal of Botany 91: 1523-1534.

Hartmann, S., J. D. NASON, and D. BhatTacharya. 2001. Extensive ribosomal DNA genic variation in the columnar cactus Lophocereus. Journal of Molecular Evolution 53: 124-134.

Holland, S. M. 2003. Analytic Rarefaction 1.3. http://www.uga.edu/ strata/software/, University of Georgia Stratigraphy Lab.

JACOBSON, D. M., and D. M. ANDERSON. 1986. Thecate heterotrophic dinoflagellates: Feeding behavior and mechanisms. Journal of Phycology 22: 249-258.

KoKInOS, J. P., and D. M. ANDERSON. 1995. Morphological development of resting cysts in cultures of the marine dinoflagellate Lingulodinium polyedrum $(=L$. machaerophorum). Palynology 19: 143-166.

LiAO, D. 1999. Concerted evolution: Molecular mechanism and biological implications. American Journal of Human Genetics 64: 24-30.

Márquez, L. M., D. J. Miller, J. B. MacKenzie, and M. J. H. van Oppen. 2003. Pseudogenes contribute to the extreme diversity of nuclear ribosomal DNA in the hard coral Acropora. Molecular Biology and Evolution 20: 1077-1086. 
NAUSTVOLL, L. J. 2000. Prey size spectra and food preferences in thecate heterotrophic dinoflagellates. Phycologia 39: 187-198.

Nunn, G. B., B. F. Theisen, B. Christensen, and P. Arctander. 1996. Simplicitycorrelated size growth of the nuclear 28S ribosomal RNA D3 expansion segment in the crustacean order Isopoda. Journal of Molecular Evolution 42: 211-223.

Reed, K., M., J. D. HACKeTt, and R. B. PhilliPs. 2000. Comparative analysis of intraindividual and inter-species DNA sequence variation in salmonid ribosomal DNA cistrons. Gene 249: 115-125.

Rehnstam-Holm, A. S., A. Godhe, and D. M. Anderson. 2002. Molecular studies of Dinophysis (Dinophyceae) species from Sweden and North America. Phycologia 41: 348-357.

Rozas, J., J. C. SÁnChz-DelBarrio, X. Messeguer, and R. Rozas. 2003. DnaSP, DNA polymorphism analyses by the coalescent and other methods. Bioinformatics 19: 2496-2497.

SANTOS, S. R., R. A. KinZIE, K. SAKAI, and M. A. Coffroth. 2003. Molecular Characterization of Nuclear Small Subunit (18S)-rDNA Pseudogenes in a Symbiotic Dinoflagellate (Symbiodinium, Dinophyta). Journal of Eukaryotic Microbiology 50: 417-421.

Scholin, C. A., D. M. ANDERson, and M. L. Sogin. 1993. Two distinct small-subunit ribosomal RNA genes in the North American toxic dinoflagellate Alexandrium fundyense (Dinophyceae). Journal of Phycology 29: 209-216.

Scholin, C. A., M. Herzog, M. Sogin, and D. M. Anderson. 1994. Identification of group- and strain-specific genetic markers for globally distributed Alexandrium (Dinophyceae). II. Sequence analysis of a fragment of the LSU rRNA gene. Journal of Phycology 30: 999-1011.

SwOFForD, D. L. 2002. PAUP*: Phylogenetic Analysis Using Parsimony (*and other methods), Version 4.0b10. Sinauer.

Venter, J. C., K. Remington, J. F. Heidelberg, A. L. Halpern, D. Rusch, J. Eisen, D. Wu, I. Paulsen, K. E. Nelson, W. Nelson, D. E. Fouts, S. LeVy, A. H. Knap, M. W. Lomas, K. Nealson, O. White, J. Peterson, J. Hoffman, R. Parsons, H. Baden-Tillson, C. PfannKoch, Y.-H. Rogers, and H. O. SMith. 
2004. Environmental genome shotgun sequencing of the Sargasso Sea. Science 304: 66-74.

YAMAGUCHI, A., and T. HoRIGUCHI. 2005. Molecular phylogenetic study of the heterotrophic dinoflagellate genus Protoperidinium (Dinophyceae) inferred from small subunit rRNA gene sequences. Phycological Research 53: 30-42.

YeUNG, P. K. K., K. F. KonG, F. T. W. Wong, and J. T. Y. Wong. 1996. Sequence data for two large-subunit rRNA genes from an Asian strain of Alexandrium catenella. Applied and Environmental Microbiology 62: 4199-4201. 


\section{Chapter 6}

Conclusions and suggestions for future study 
This thesis has explored the ecology, life history, molecular phylogeny, and intraspecific sequence variability of marine thecate heterotrophic dinoflagellates. The work has broadened our understanding of the Protoperidinium and diplopsalids, providing new insights into the ecological and evolutionary relationships of these heterotrophs with other plankton species.

\section{Ecologies of Protoperidinium species}

In Chapter 2, I describe the distributions of individual Protoperidinium species and their associations with particular phytoplankton species off the southwestern coast of Ireland during July of 2003. In that region, individual Protoperidinium species had distributions that appeared to be defined by a combination of hydrographic conditions and the presence of preferred phytoplankton prey species.

Phytoplankton and planktonic protists are frequently lumped into broad categories during field sampling programs, and treated as though all species in a group have the same ecology. As evidenced by the results of this study of the distribution of Protoperidinium species off the southwest coast of Ireland, such an approach leads to very limited insights into the real ecology of the plankton community. At the time of my study, the distributions of individual Protoperidinium species varied widely from that of Protoperidinium spp. as a whole. When taken together with the fact that many Protoperidinium species are very specific feeders, it becomes clear that the distributions and predator-prey interactions of individual species will need to be investigated separately to understand the trophic dynamics of plankton populations.

Unfortunately, exploring the ecologies of individual Protoperidinium species is more easily said than done, as this approach requires considerable expertise with Protoperidinium taxonomy and species identification using thecal plate morphology. As molecular tools are developed to reliably identify Protoperidinium species, studies of Protoperidinium species ecologies should become more routine. 
Suppositions about the relationships between individual Protoperidinium species and their prey based on co-occurrence of species in the field can and should be tested in the laboratory. Also necessary is examination of the tolerances of Protoperidinium to a range of environmental conditions. To my knowledge, this type of work, even simply examining the basic temperature and salinity limits of Protoperidinium species, has never been performed. Such work would help define the ecologies of Protoperidinium species.

\section{Life history and resulting complications for species identification}

The description of the life history of $P$. steidingerae in Chapter 3 is the first of its kind for any Protoperidinium species. Protoperidinium steidingerae has an asexual cycle including division by eleutheroschisis and the production of daughter cells that initially have a morphology quite different than that of fully developed vegetative cells. In the sexual cycle, fusion of isogamous gametes gives rise to an apparently diploid planozygote. Dormant hypnozygotes were formed from the planozygotes. After a dormancy period of approximately 70 days, the hypnozygotes germinated, giving rise to diploid planomeiocytes. Preliminary evidence suggests that the planomeiocytes undergo nuclear cyclosis (meiosis) and differentiate to form vegetative cells and return to the asexual cycle.

As described in Appendix 2, initial observations on the life cycle of another species, $P$. depressum, when compared with the results of observations of the $P$. steidingerae life cycle, indicate that different species of Protoperidinium have different life histories. Protoperidinium depressum for example, also seems to also divide by eleutheroschisis, but some of these divisions resulted in four daughter cells, not just two as in $P$. steidingerae. Additionally, fusion of putative $P$. depressum gametes was witnessed, and large swimming cells with two longitudinal flagella (presumptive planozygotes) were observed, but hypnozygotes were never detected in culture. These observations and the lack of detection of $P$. depressum hypnozygotes in the field may mean that $P$. depressum has a sexual cycle that does not include dormant hypnozygotes. In the case of $P$. depressum, nuclear cyclosis was witnessed in a presumptive planozygote. 
This investigation of life history has brought to light some of the current problems with the taxonomy of the Protoperidinium. The hypnozygotes and vegetative cells of $P$. steidingerae have probably been previously mis-identified as those of $P$. oblongum (Wall and Dale 1968), and there is evidence that different sizes of vegetative cells of $P$. steidingerae have recently been established as two new Protoperidinium species (Faust 2006). The differences between gametes and vegetative cells of $P$. depressum indicate that thecal plate morphology may not be conserved among all life history stages. The $P$. depressum gamete, if identified independently from a field sample, would be identified not only as a separate species, but would be placed in a separate subgenus, the Archaeperidinium, as it has only two intercalary plates.

Culturing of additional species and close observations of morphologies that arise in those cultures is necessary to differentiate life history stages from separate species. I recommend the use of molecular techniques to confirm the identity of Protoperidinium species from field samples. Molecular methods could be particularly useful in discriminating between existing species and in establishing new species with similar gross and/or thecal plate morphologies.

Interestingly, sexuality appeared to be constitutive in my cultures of $P$. steidingerae and P. depressum. Protoperidinium species may normally continuously undergo sexual reproduction, or constitutive sexuality may be due to a culture artifact of crowding or food limitation that did not negatively impact the growth of the culture. Experiments to determine the triggers for sexual reproduction of Protoperidinium species can be run in the laboratory. The results of such studies, together with the information this thesis has provided about asexual reproduction and the mandatory dormancy period of hypnozygotes, can provide information valuable to better understanding the role of life history in the seasonality and ecology of Protoperidinium in the field. 


\section{The relationship between molecular phylogeny and morphologically-based taxonomy}

The investigation of the molecular phylogeny of the Protoperidinium and diplopsalids in Chapter 4 indicates that the group is monophyletic, and that historical morphologically based groupings are evolutionarily relevant. Like the life history studies however, this work on molecular phylogeny points to the need to re-evaluate the taxonomy of the Protoperidinium. While the major morphological sections of Protoperidinium seem to be validated by the molecular phylogeny presented here, some complications have become apparent.

The diplopsalids and Protoperidinium apparently do not follow a simple model of evolution based on thecal plate increase or reduction. Additionally, the subgenra separation of the Archaeperidinium and the Protoperidinium may not be valid, since $P$. excentricum, currently of the subgenus Archaeperidinium, falls within the subgenus Protoperidinium clade in this and other molecular phylogenies produced to date (Yamaguchi and Horiguchi 2005). Only sequencing and phylogenetic analysis of additional species from a range of morphological sections will confirm or deny the pertinence of the current taxonomic designations of Protoperidinium species.

Future studies will need to combine morphology and molecular biology in species identifications and phylogenetic investigations. Single-cell PCR methods will be helpful in this regard. The new method developed by Takano and Horiguchi (2005) which allows identification of a single cell by light microscopy, SEM, and then molecular identification by PCR and sequencing of multiple genes may be instrumental to doing this work without intensive culturing of thecate heterotrophic dinoflagellates.

As additional studies of molecular phylogeny and life history are conducted for thecate heterotrophic dinoflagellates, we will be able to investigate the relationship between the two. Do more closely related species share similar life histories, for example? The work herein indicates that they may not, and the closely related $P$. steidingerae and $P$. depressum appear to have different life histories. 


\section{Intragenomic sequence variability}

In the process of studying the molecular phylogeny of thecate heterotrophic dinoflagellates, I uncovered a high level of intragenomic LSU rDNA sequence diversity among members of the group. As described in Chapter 5, the level of sequence diversity varied between evolutionary clades, with the diplopsalids having very low intraspecific sequence diversity and the Orthoperidinium and Testeria having very high levels of intraspecific diversity.

Additional work will be needed to determine the full level of sequence diversity in the Protoperidinium. Further investigation of intraspecific diversity could provide insight into the complex structure of the dinoflagellate genome and into what may be unique mechanisms of DNA repair and replication. The sequence variants found here might also serve as useful markers for populations in the field. Research will be required to determine if sequence variants evolve quickly and are specific to populations, or if they arose at the time of speciation and are the same within diverse geographic isolates of the same species.

\section{Toxicity in Protoperidinium}

The major impetus for undertaking this research on thecate heterotrophic dinoflagellates in general, and Protoperidinium in particular, was the identification of $P$. crassipes as the source of the newly discovered shellfish toxin, AZA (James et al. 2003). Unfortunately, due to technical difficulties with toxin analysis, we were unable to pursue investigation of the role of $P$. crassipes in the production of AZA toxins. The link between AZA and $P$. crassipes now appears tenuous, and additional studies are needed to confirm or refute whether the organism plays a role in AZA toxin dynamics.

Many questions about the toxicity of $P$. crassipes remain to be addressed. First, it would be ideal to confirm toxin production in clonal cultures of $P$. crassipes, to avoid possible contamination by morphologically similar species including $P$. curtipes, $P$. depressum, and $P$. divergens. Second, we do not know if the cosmopolitan $P$. crassipes is toxic in 
areas of the world beyond Northwestern Europe. For example, anecdotal reports suggest that $P$. crassipes in Canadian waters is non-toxic (A. Cembella, pers. comm.). Third, we do not know if other, closely related Protoperidinium species might also produce AZAs. Finally, we do not know what environmental factors might influence the toxicity in the species. Given the heterotrophic nature of $P$. crassipes, we have yet to determine if the toxin is produced internally or by an ingested source. Even if the toxin is produced autonomously, we do not understand how toxin composition or content may vary with changing nutritional status or prey type in $P$. crassipes.

Several examples of toxin production changing with varying nutrient status or environmental conditions have been demonstrated in toxic phototrophic, mixotrophic, and heterotrophic dinoflagellates. In batch cultures of the phototrophic PSP toxin producer, Alexandrium fundyense, phosphate limitation and low temperatures both increase toxin concentration per cell, while nitrate limitation reduces total cellular toxin concentration relative to a nutrient-replete control (Anderson et al. 1990b). In semicontinuous cultures of $A$. fundyense, toxin composition (the relative abundances of individual toxin epimers) varies systematically with growth rate and with type of nutrient-stress (Anderson et al. 1990a). Phosphate limitation in the mixotrophic toxic haptophyte Prymesium results in an increase in prymesiotoxin hemolytic activity, but when nutrient limited cultures are fed bacteria, hemolytic activity decreases (Legrand et al. 2001). The heterotroph Pfiesteria piscida has toxic and non-toxic stages depending on food source, with icthyotoxicity only prompted by exposure to fish prey (Burkholder and Glasgow Jr. 1997). Thus, we may expect that there is some influence of feeding history on the toxin production of $P$. crassipes.

Studies should be done to determine if $P$. crassipes or other Protoperidinium species could act as trophic vectors for phycotoxins. My preliminary attempts to feed $A$. fundyense to $P$. crassipes, to determine if $P$. crassipes could accumulate saxitoxin from its prey and thereby act as a vector for phycotoxins in marine food webs were unsuccessful. In culture, $P$. crassipes did not consume $A$. fundyense, despite the fact that $P$. crassipes successfully survives in culture on the similar sized dinoflagellate 
Lingulodinium polyedrum. Additional work to determine if $P$. crassipes is a source or an accumulator of AZA and other shellfish toxins will be necessary.

\section{SUMMARY}

In conclusion, this has thesis enhanced the understanding of marine thecate heterotrophic dinoflagellates. The ecologies, life histories, and evolutionary background of Protoperidinium and diplopsalid species, while seemingly diverse topics, are inextricably linked, and define the role of these heterotrophs in plankton communities.

\section{REFERENCES}

Anderson, D. M., D. M. Kulis, J. J. Sullivan, and S. Hall. 1990a. Toxin composition variations in one isolate of the dinoflagellate Alexandrium fundyense. Toxicon 28: 885-893.

Anderson, D. M., D. M. Kulis, J. J. Sullivan, S. Hall, and C. W. Lee. 1990 b. Dynamics and physiology of saxitoxin production by the dinoflagellates Alexandrium spp. Marine Biology 104: 511-524.

BurKholder, J. A. M., and H. B. Glasgow JR. 1997. Trophic controls on stage transformations of a toxic ambush predator dinoflagellate. Journal of Eukaryotic Microbiology 44: 200-205.

FAust, M. A. 2006. Creation of the subgenus Testeria Faust subgen. nov. Protoperidinium Bergh from the SW Atlantic Ocean: Protoperidinium novella sp. nov. and Protoperidinium conicinna sp. nov. Dinophyceae. Phycologia 45: 19.

JAMES, K. J. and others. 2003. Ubiquitous 'benign' alga emerges as the cause of shellfish contamination responsible for the human toxic syndrome, azaspiracid poisoning. Toxicon 41: 145-151.

Legrand, C., N. Johansson, G. Johnsen, K. Y. Borsheim, and E. Graneli. 2001. Phagotrophy and toxicity variation in the mixotrophic Prymnesium patelliferum (Haptophyceae). Limnology and Oceanography 46: 1208-1214.

TAKANO, Y., and T. HORIGUCHI. 2005. Acquiring scanning electron microscopical, light microscopical and multiple gene sequence data from a single dinoflagellate cell. Journal of Phycology 42: 251-256. 
WALL, D., and B. DALE. 1968. Modern dinoflagellate cysts and evolution of the Peridiniales. Micropaleontology 14: 265-304.

YAmaguchi, A., and T. HoRiguchi. 2005. Molecular phylogenetic study of the heterotrophic dinoflagellate genus Protoperidinium (Dinophyceae) inferred from small subunit rRNA gene sequences. Phycological Research 53: 30-42. 
REFERENCES 
ABé, T. H. 1981. Studies on the Family Peridiniidae: An Unfinished Monograph of the Armoured Dinoflagellata. Academia Scientific Book, Inc.

AgUilerA, A., and H. L. KLEIN. 1989. Yeast interchromosomal recombination: Long gene conversion tracts are preferentially associated with reciprocal exchange and require the $R A D 1$ and $R A D 3$ gene products. Genetics 123: 683-694.

AlVERSON, A. J., and L. KoLNICK. 2005. Intragenomic nucleotide polymorphism among small subunit (18S) rDNA paralogs in the diatom genus Skeletonema (Bacillariophyta). Journal of Phycology 41: 1248-1257.

Anderson, D. M. 1998. Physiology and bloom dynamics of toxic Alexandrium species, with emphasis on life cycle transitions, p. 29-48. In D. M. Anderson, A. D. Cembella and G. M. Hallegraeff [eds.], Physiological Ecology of Harmful Algal Blooms. NATO ASI Series. Springer-Verlag.

ANDERSON, D. M., and B. A. KEAFER. 1987. An endogenous annual clock in the toxic marine dinoflagellate Gonyaulax tamarensis. Nature 325: 616-617.

ANDERSON, D. M., D. M. KuLIS, and B. J. BindER. 1984. Sexuality and cyst formation in the dinoflagellate Gonyaulax tamarensis: Cyst yield in batch cultures. Journal of Phycology 20: 418-425.

Anderson, D. M., D. M. Kulis, J. J. Sullivan, and S. Hall. 1990a. Toxin composition variations in one isolate of the dinoflagellate Alexandrium fundyense. Toxicon 28: 885-893.

Anderson, D. M., D. M. Kulis, J. J. Sullivan, S. Hall, and C. W. LeE. 1990b. Dynamics and physiology of saxitoxin production by the dinoflagellates Alexandrium spp. Marine Biology 104: 511-524.

ANDERSON, D. M., and K. RENGEFORS. 2006. Community assembly and seasonal succession of marine dinoflagellates in a temperate estuary: The importance of life cycle events. Limnology and Oceanography 51: 860-873.

ANDERSON, D. M., and D. WALL. 1978. Potential importance of benthic cysts of Gonyaulax tamarensis and G. excavata in initiating toxic dinoflagellate blooms. Journal of Phycology 14: 224-234. 
Archer, S. D., R. J. G. Leakey, P. H. Burkill, and M. A. Sleigh. 1996. Microbial dynamics in coastal waters of East Antarctica: Herbivory by heterotrophic dinoflagellates. Marine Ecology Progress Series 139: 1-3.

Arnheim, N., M. Krystal, R. Schmickel, G. Wilson, O. Ryder, and E. Zimmer. 1980. Molecular evidence for exchanges among ribosomal genes on nonhomologous chromosomes in man and apes. Proceedings of the National Academy of Sciences, USA 77: 7323-7327.

BALECH, E. 1974. El genero Protoperidinium Bergh, 1881 (Peridinium Ehrenberg, 1831, Partim). Revista del Museo Argentino de Ciencias Naturales "Bernardino Rivadavia" e Instituto Nacional de Investigacion de las Ciencias Naturales 4: 179.

---. 1979. Tres Dinoflagelados nuevos o interesantes de aguas Basileñas. Bolm Inst. Oceanogr., S. Paulo 28: 55-64.

BARNES, W. M. 1992. The fidelity of Taq polymerase catalyzing PCR is improved by an $\mathrm{N}$-terminal deletion. Gene 112: 29-35.

Bergh, R. S. 1881. Der organismus der Cilioflagellaten. Morph. Jahrb. 7: 177-288.

BoLCH, C. J. S. 2001. PCR protocols for genetic identification of dinoflagellates directly from single cysts and plankton cells. Phycologia 40: 162-167.

BROWNELl, E., M. KRYSTAL, and N. ARNHEIM. 1983. Structure and evolution of human and African ape rDNA pseudogenes. Molecular Biology and Evolution 1: 29-37.

BURKHOldER, J. A. M., and H. B. Glasgow JR. 1997. Trophic controls on stage transformations of a toxic ambush predator dinoflagellate. Journal of Eukaryotic Microbiology 44: 200-205.

BUSKEY, E. J. 1997. Behavioral components of feeding selectivity of the heterotrophic dinoflagellate Protoperidinium pellucidum. Marine Ecology Progress Series 153: 77-89.

Buskey, E. J., C. J. Coulter, and S. L. Brown. 1994. Feeding, growth and bioluminescence of the heterotrophic dinoflagellate Protoperidinium huberi. Marine Biology 121: 373-380. 
CARIEllo, N. F., J. A. Swenberg, and T. R. SKoPeK. 1991. Fidelity of Thermococcus litoralis DNA polymerase (Vent) in PCR determined by denaturing gradient gelelectrophoresis. Nucleic Acids Research 19: 4193-4198.

Cembella, A. D., A. G. Bauder, N. I. Lewis, and M. A. Quilliam. 2001. Association of the gonyaulacoid dinoflagellate Alexandrium ostenfeldii with spirolide toxins in size-fractionated plankton. Journal of Plankton Research 23: 1413-1419.

Cetta, C. M., and D. M. Anderson. 1990. Cell cycle studies of the dinoflagellates Gonyaulax polyedra Stein and Gyrodinium uncatenum Hulburt during asexual and sexual reproduction. Journal of Experimental Marine Biology and Ecology 135: 69-84.

Chisholm, S. W., E. V. Armbrust, and R. J. Olson. 1986. The individual cell in phytoplankton ecology: cell cycles and application of flow cytometry, p. 343-369. In T. Platt and W. K. W. Li [eds.], Photosynthetic Picoplankton. Can. Bull. Fish. Aquat. Sci.

Cline, J., J. C. BRaman, and H. H. Hogrefe. 1996. PCR fidelity of $P f u$ DNA polymerase and other thermostable DNA polymerases. Nucleic Acids Research 24: 3546-3551.

CoAts, D. W. 2002. Dinoflagellate life-cycle complexities. Journal of Phycology 38: 417-419.

COATS, D. W., and J. F. HEINBOKEL. 1982. A study of reproduction and other life cycle phenomena in planktonic protists using an acridine orange fluorescence technique. Marine Biology 67: 71-79.

CoATs, D. W., M. A. TYleR, and D. M. ANDERSON. 1984. Sexual processes in the life cycle of Gyrodinium uncatenum (Dinophyceae): A morphogenic overview. Journal of Phycology 20: 351-361.

Cusack, C., J. Silke, G. McDermott, T. NokklegaARD, G. Nolan, M. Gilmartin, and R. RAINE. 2006. The Biological Oceanography of Harmful Algal Blooms (BOHAB) Programme: Special emphasis on the dinoflagellate genus Dinophysis, p. 55-63, 6th Irish Shellfish Safety Scientific Workshop. Marine Institute.

DaugbJerg, N., G. HANSEn, J. Larsen, and Ø. Moestrup. 2000. Phylogeny of some of the major genera of dinoflagellates based on ultrastructure and partial LSU rDNA 
sequence data, including the erection of three new genera of unarmoured dinoflagellates. Phycologia 39: 302-317.

Dodge, J. D. 1982. Marine Dinoflagellates of the British Isles. Her Majesty's Stationery Office.

---. 1983. Ornamentation of thecal plates in Protoperidinium (Dinophyceae) as seen by scanning electron microscopy. Journal of Plankton Research 5: 119-127.

Dodge, J. D., and H. Hermes. 1981. A revision of the Diplopsalis group of dinoflagellates (Dinophyceae) based on material from the British Isles. Botanical Journal of the Linnean Society 53: 15-26.

Dover, G. 1982. Molecular drive: a cohesive mode of species evolution. Nature 299: 111-116.

Edwards, A., K. J. Jones, J. M. Graham, C. R. Griffiths, N. MacDougall, J. W. PATChING, J. M. RICHARD, and R. RAINE. 1996. Transient coastal upwelling and water circulation in Bantry Bay, a ria on the SW coast of Ireland. Estuarine, Coastal and Shelf Science 42: 213-230.

ElBRÄCHTER, M. 1993. Kolkwitziella Lindemann 1919 and Preperidinium Mangin 1913: correct genera names in the Diplopsalis-group (Dinophyceae). Nova Hedwigia 56: $173-178$.

ELDER, J., JOHN, F., and B. J. TURNER. 1995. Concerted evolution of repetitive DNA sequences in eukaryote. The Quarterly Review of Biology 70: 297-320.

EllegaArd, M., N. Daugbjerg, A. Rochon, J. Lewis, and I. Harding. 2003. Morphological and LSU rDNA sequence variation within the Gonyaulax spinifera-spiniferites group (Dinophyceae) and proposal of $G$. elongata comb. nov. and G. membranacea comb. nov. Phycologia 42: 151-164.

FAUST, M. A. 2006. Creation of the subgenus Testeria Faust subgen. nov. Protoperidinium Bergh from the SW Atlantic Ocean: Protoperidinium novella sp. nov. and Protoperidinium conicinna sp. nov. Dinophyceae. Phycologia 45: 19.

Fensome, R. A., F. J. R. TAylor, G. Norris, W. A. S. Sarjeant, D. I. Waharton, and G. L. WILliams. 1993. A classification of living and fossil dinoflagellates. Micropaleontology, Special Publication Number 7: 1-351. 
FigUEROA, R. I., and I. Bravo. 2005. A study of the sexual reproduction and determination of mating type of Gymnodinium nolleri (Dinophyceae) in culture. Journal of Phycology 41: 74-83.

FILEMAN, E. S., and P. BURKILL. 2001. The herbivorous impact of microzooplankton during two short-term Lagrangian experiments off the NW coast of Galacia in summer 1998. Progress in Oceanography 51: 361-383.

Flanagan, A. F. 2002. Detection and biochemical studies on the novel algal toxin, azaspiracid, p. 117, Department of Biochemistry. National University of Ireland, Galway.

FRANKS, P. J. S., and D. M. ANDERSON. 1992. Alongshore transport of a toxic phytoplankton bloom in a buoyancy current: Alexandrium tamarense in the Gulf of Maine. Marine Biology 116: 153-164.

FRITZ, L., and R. E. TRIEMER. 1985. A rapid simple technique utilizing Calcofluor white M2R for the visualization of dinoflagellate thecal plates. Journal of Phycology 21: 662-664.

GAINES, G., and M. ELBRÄCHTER. 1987. Heterotrophic nutrition, p. 225-268. In F. J. R. Taylor [ed.], The Biology of Dinoflagellates. Botanical Monographs. Blackwell Scientific Publications.

GAINES, G., and F. J. R. TAYLOR. 1984. Extracellular digestion in marine dinoflagellates. Journal of Plankton Research 6: 1057-1062.

Gernandt, D. S., A. Liston, and D. PiñERo. 2001. Variation in the nrDNA ITS of Pinus subsection Cembroides: Implications for molecular systematic studies of pine species complexes. Molecular Phylogenetics and Evolution 21: 449-467.

Godhe, A., D. M. ANDERSON, and A. S. RehnSTAM-Holm. 2002. PCR amplification of microalgal DNA for sequencing and species identification: studies on fixatives and algal growth stages. Harmful Algae 1: 375-382.

Graneli, E., D. M. ANDERson, P. CARLSSON, and S. Y. Maestrini. 1997. Light and dark carbon uptake by Dinophysis species in comparison to other photosynthetic and heterotrophic dinoflagellates. Aquatic Microbial Ecology 13: 177-186.

Granel, E., and P. CARLSSON. 1998. The ecological significance of phagotrophy in photosynthetic dinoflagellates, p. 539-557. In D. M. Anderson, A. D. Cembella 
and G. M. Hallegraeff [eds.], Physiological Ecology of Harmful Algal Blooms. Springer-Verlag.

GRIBBLE, K. E., and D. M. ANDERSON. In press. Molecular phylogeny of the heterotrophic dinoflagellates, Protoperidinium, Diplopsalis, and Preperidinium (Dinophyceae), inferred from LSU ribosomal DNA. Journal of Phycology.

GUILLARD, R. R. L. 1975. Culture of phytoplankton for feeding marine invertebrates. In W. L. Smith and M. H. Chanley [eds.], Culture of Marine Invertebrates. Plenum Publishing Corporation.

Hackett, J. D., D. M. ANDERson, D. L. ERdNer, and D. Bhattacharya. 2004. Dinoflagellates: A remarkable evolutionary experiment. American Journal of Botany 91: 1523-1534.

HANSEN, B., P. K. BJORNSEN, and P. J. HANSEN. 1994. Prey size selection in planktonic zooplankton. Limnology and Oceanography 39: 395-403.

HANSEN, G., N. DaugbJerg, and J. M. FranCo. 2003. Morphology, toxin composition and LSU rDNA phylogeny of Alexandrium minutum (Dinophyceae) from Denmark, with some morphological observations on other European strains. Harmful Algae 2: 317-335.

HANSEN, G., N. DAugBJerg, and P. HenRIKSEN. 2000. Comparative study of Gymnodinium mikimotoi and Gymnodinium aureolum, comb. nov. (=Gyrodinium aureolum) based on morphology, pigment composition, and molecular data. Journal of Phycology 36: 394-410.

HANSEN, P. J. 1992. Prey size selection, feeding rates and growth dynamics of heterotrophic dinoflagellates with special emphasis on Gyrodinium spirale. Marine Biology, Heidelberg 114: 327-334.

HARTMANN, S., J. D. NASON, and D. BhatTACHARYA. 2001. Extensive ribosomal DNA genic variation in the columnar cactus Lophocereus. Journal of Molecular Evolution 53: 124-134.

HASLE, G. R. 1978. Using the inverted microscope, p. 191-196. In A. Sournia [ed.], Phytoplankton Manual. Unesco.

HollaND, S. M. 2003. Analytic Rarefaction 1.3. http://www.uga.edu/ strata/software/, University of Georgia Stratigraphy Lab. 
Huang, W. G., A. P. Cracknell, R. A. Vaughan, and P. A. Davies. 1991. A satellite and field view of the Irish Shelf front. Continental Shelf Research 11: 543-562.

Ito, E., M. Satake, K. Ofuji, M. Higashi, K. Harigaya, T. McMahon, and T. YASUMOTO. 2002. Chronic effects in mice caused by oral administration of sublethal doses of azaspiracid, a new marine toxin isolated from mussels. Toxicon 40: 193-203.

JACOBSON, D. M. 1987. The ecology and feeding behaviour of thecate heterotrophic dinoflagellates, p. 209, Joint Program in Oceanography and Engineering. Woods Hole Oceanographic Institution-Massachusetts Institute of Technology.

JACOBSON, D. M., and R. A. ANDERSEN. 1994. The discovery of mixotrophy in photosynthetic species of Dinophysis (Dinophyceae): Light and electron microscopical observations of food vacuoles in Dinophysis acuminata, $D$. norvegica and two heterotrophic dinophysoid dinoflagellates. Phycologia 33: 97 110.

JACOBSON, D. M., and D. M. ANDERSON. 1986. Thecate heterotrophic dinoflagellates: Feeding behavior and mechanisms. Journal of Phycology 22: 249-258.

JAKOBSEN, H. H., and P. J. HANSEN. 1997. Prey size selection, grazing and growth response of the small heterotrophic dinoflagellate Gymnodinium sp. and the ciliate Balanion comatum - a comparative study. Marine Ecology Progress Series 158: 75-86.

James, K. J., A. Furey, M. Lehane, H. Ramstad, T. Aune, P. HovgaArd, S. Morris, W. Higman, M. SATAKE, and T. YASUMOTO. 2002a. First evidence of an extensive northern European distribution of azaspiracid poisoning (AZP) toxins in shellfish. Toxicon 40: 909-915.

James, K. J., C. Moroney, C. Roden, M. Satake, T. Yasumoto, M. Lehane, and A. FUREY. 2003. Ubiquitous 'benign' alga emerges as the cause of shellfish contamination responsible for the human toxic syndrome, azaspiracid poisoning. Toxicon 41: 145-151.

James, K. J., M. D. Sierra, M. Lehane, A. B. Magdalena, C. Moroney, and A. FUREY. 2002b. Azaspiracid poisoning: Aetiology, toxin dynamics and new analogues in shellfish, Xth International Conference on Harmful Algal Blooms. 
JEONG, H. J. 1995. The interactions between microzooplanktonic grazers and dinoflagellates causing red tides in the open coastal waters off southern California, p. 139, Oceanography. University of California San Diego.

---. 1996. The predation impact by the heterotrophic dinoflagellate Protoperidinium cf. divergens on copepod eggs in the presence of co-occurring phytoplankton prey. Journal of the Oceanological Society of Korea. Seoul 31: 144-149.

JEONG, H. J., and M. I. LATZ. 1994. Growth and grazing rates of the heterotrophic dinoflagellates Protoperidinium spp. on red tide dinoflagellates. Marine Ecology Progress Series 106: 173-185.

JÖRGENSEN, E. 1912. Bericht über die von der schwedischen hydrographischbiologischen Kommission in den schwedischen Gewässern in den Jahren 19091910 eingesammelten Planktonproben. Svenska Hydrogr.-Biol. Komm. Skr. 4: 120.

KJaeret, A. H., L. J. Naustvoll, and E. PaAsche. 2000. Ecology of the heterotrophic dinoflagellate genus Protoperidinium in the inner Oslofjord (Norway). Sarsia 85: 5-6.

KofoID, C. A. 1907. Dinoflagellata of the San Diego Region, III. Descriptions of New Species. The University Press.

---. 1909. On Peridinium steinii Jörgensen, with a note on the nomenclature of the skeleton of the Peridinidae. Archiv. fur Protistenkunde 16: 25-47.

KoKInOS, J. P., and D. M. ANDERSON. 1995. Morphological development of resting cysts in cultures of the marine dinoflagellate Lingulodinium polyedrum $(=L$. machaerophorum). Palynology 19: 143-166.

Lebour, M. V. 1922. Plymouth Peridinians. J. Mar. Biol. Ass., Plymouth 12.

Legrand, C., N. Johansson, G. Johnsen, K. Y. Borsheim, and E. Graneli. 2001. Phagotrophy and toxicity variation in the mixotrophic Prymnesium patelliferum (Haptophyceae). Limnology and Oceanography 46: 1208-1214.

LessARD, E. J., and M. C. MURRELL. 1996. Distribution, abundance and size composition of heterotrophic dinoflagellates and ciliates in the Sargasso Sea near Bermuda. Deep-Sea Research (Part I, Oceanographic Research Papers) 43: 1045-1065. 
LESSARD, E. J., and E. SWIFT. 1985. Species-specific grazing rates of heterotrophic dinoflagellates in oceanic waters, measured with a dual-label radioisotope technique. Marine Biology 87: 289-296.

LEVINSEN, H., and T. G. NiELSEN. 2002. The trophic role of marine pelagic ciliates and heterotrophic dinoflagellates in Arctic and temperate coastal ecosystems: A crosslatitude comparison. Limnology and Oceanography 47: 427-439.

LeVinsen, H., T. G. Nielsen, and B. W. HANSEN. 2000. Annual succession of marine pelagic protozoans in Disko Bay, West Greenland, with emphasis on winter dynamics. Marine Ecology Progress Series 206: 119-134.

LEWIS, J., J. D. DodGE, and P. TeTT. 1984. Cyst-theca relationships in some Protoperidinium species (Peridiniales) from Scottish sea lochs. J. micropalaeontol. 3: 25-34.

LIAO, D. 1999. Concerted evolution: Molecular mechanism and biological implications. American Journal of Human Genetics 64: 24-30.

MARGULIS, L. 1968. Evolutionary criteria in Thallophytes: a radical alternative. Science 161: $1020-1022$.

---. 1970. Origins of Eukaryotic Cells. Yale University Press.

MAtsuOKA, K. 1988. Cyst-theca relationships in the Diplopsalid group (Peridiniales, Dinophyceae). Review of Paleobotany and Palynology 56: 95-122.

McMahon, T., R. RAINE, and J. SILKE. 1998. Oceanographic control of harmful phytoplankton blooms around southwestern Ireland, p. 128-129. In B. Reguera, J. Blanco, M. L. Fernández and T. Wyatt [eds.], VII International Conference on Harmful Algal Blooms. Xunta de Galacia and Intergovernmental Oceanographic Commission of UNESCO.

McMahon, T., R. Raine, O. Titov, and S. BoyChuK. 1995. Some oceanographic features of northeastern Atlantic waters west of Ireland. ICES Journal of Marine Science 52: 221-232.

Menden-Deuer, S., E. J. LesSARD, J. SATterberg, and D. Grünbaum. 2005. Growth rates and starvation survival of three species of the pallium-feeding, thecate dinoflagellate genus Protoperidinium. Aquatic Microbial Ecology 41: 145-152. 
Montagnes, D. J. S., and D. H. LynN. 1993. A Quantitative Protargol Stain (QPS) for ciliates and other protists, p. 229-240. In P. F. Kemp, B. F. Sherr, E. B. Sherr and J. B. Cole [eds.], Handbook of Methods in Aquatic Microbial Ecology. Lewis Publishers, CRC Press, Inc.

Moran, S., J. Silke, R. Salas, T. Chamberlan, J. Lyons, J. Flannery, V. Thornton, D. Clarke, and L. Devilly. 2005. Review of Phytoplankton Monitoring 2005, p. 4-10, Proceedings of the 6th Irish Shellfish Safety Scientific Workshop. Marine Institute.

Márquez, L. M., D. J. Miller, J. B. MacKenzie, and M. J. H. van Oppen. 2003. Pseudogenes contribute to the extreme diversity of nuclear ribosomal DNA in the hard coral Acropora. Molecular Biology and Evolution 20: 1077-1086.

Naustvoll, L. J. 1998. Growth and grazing by the thecate heterotrophic dinoflagellate Diplopsalis lenticula (Diplopsalidaceae, Dinophyceae). Phycologia 37: 1-9.

---. 2000. Prey size spectra and food preferences in thecate heterotrophic dinoflagellates. Phycologia 39: 187-198.

Nunn, G. B., B. F. Theisen, B. Christensen, and P. Arctander. 1996. Simplicitycorrelated size growth of the nuclear 28S ribosomal RNA D3 expansion segment in the crustacean order Isopoda. Journal of Molecular Evolution 42: 211-223.

PARROW, M. W., and J. M. BURKHOLDER. 2002. Flow cytometric determination of zoospore DNA content and population DNA distribution in cultured Pfiesteria spp. (Pyrrhophyta). Journal of Experimental Marine Biology and Ecology 267: 35-51.

---. 2004. The sexual life cycles of Pfiesteria piscicida and cryptoperidiniopsoids (Dinophyceae). Journal of Phycology 40: 664-673.

Parrow, M. W., J. M. Burkholder, N. J. Deamer, and C. Zhang. 2002. Vegetative and sexual reproduction in Pfiesteria spp. (Dinophyceae) cultured with algae prey, and inferences for their classification. Harmful Algae 1: 5-33.

Paulsen, O. 1931. Études sur le microplancton de la mer d'Alboran. Trabajos del Instituto Espanol De Oceanografia, Madrid 4: 1-108. 
Pfiester, L. A., and D. M. ANDERSON. 1987. Dinoflagellate reproduction, p. 611-648. In F. J. R. Taylor [ed.], The Biology of Dinoflagellates. Botanical Monographs. Blackwell Scientific Publications.

Posada, D., and K. A. CRANDAll. 1998. MODELTEST: testing the model of DNA substitution. Bioinformatics 14: 817-818.

PoucheT, G. 1883. Contribution a l'histoir des Cilio-flagellates. Journ. Anat. Physiol. 19: $399-455$.

Raine, R., B. Joyce, J. Richard, Y. Pazos, M. Moloney, K. J. Jones, and J. W. PATCHING. 1993. The development of a bloom of the dinoflagellate Gyrodinium aureolum (Hulbert) on the south-west Irish coast. ICES Journal of Marine Science 50: 461-469.

RAINE, R., and T. McMahon. 1998. Physical dynamics on the continental shelf off southwestern Ireland and their influence on coastal phytoplankton blooms. Continental Shelf Research 18: 883-914.

Raine, R., S. O'Boyle, T. O'Higgins, M. White, J. W. Patching, B. Cahill, and T. McMahon. 2001. A satellite and field portrait of a Karenia mikimotoi bloom off the south coast of Ireland, August 1998. Hydrobiologia 465: 187-193.

RAINE, R., J. O'MAHONEY, T. McMahon, and C. RoDEN. 1990. Hydrography and phytoplankton of waters of South-west Ireland. Estuarine, Coastal and Shelf Science 30: 579-592.

REED, K., M., J. D. HACKeTt, and R. B. PhILliPS. 2000. Comparative analysis of intraindividual and inter-species DNA sequence variation in salmonid ribosomal DNA cistrons. Gene 249: 115-125.

Rehnstam-Holm, A. S., A. Godhe, and D. M. ANDERSON. 2002. Molecular studies of Dinophysis (Dinophyceae) species from Sweden and North America. Phycologia 41: 348-357.

RoNQUiST, F., and J. P. HUELSENBECK. 2003. MrBayes 3: Bayesian phylogenetic inference under mixed models. Bioinformatics 19: 1572-1574.

Rozas, J., J. C. SÁnchz-DelBarrio, X. Messeguer, and R. Rozas. 2003. DnaSP, DNA polymorphism analyses by the coalescent and other methods.

Bioinformatics 19: 2496-2497. 
SAldarriaga, J. F., F. J. R. TAYloR, T. CAVAlier-Smith, S. MEnden-Deuer, and P. J. KEELING. 2004. Molecular data and the evolutionary history of the dinoflagellates. European Journal of Protistology 40: 85-111.

Saldarriaga, J. F., F. J. R. Taylor, P. J. Keeling, and T. Cavalier-Smith. 2001. Dinoflagellate nuclear SSU rRNA Phylogeny Suggests Multiple Plastid Losses and Replacements. Journal of Molecular Evolution 53: 204-213.

SAntos, S. R., R. A. KinziE, K. SAKAI, and M. A. Coffroth. 2003. Molecular Characterization of Nuclear Small Subunit (18S)-rDNA Pseudogenes in a Symbiotic Dinoflagellate (Symbiodinium, Dinophyta). Journal of Eukaryotic Microbiology 50: 417-421.

Saunders, G. W., D. R. A. Hill, J. P. Sexton, and R. A. Andersen. 1997. Smallsubunit ribosomal RNA sequences from selected dinoflagellates: testing classical evolutionary hypotheses with molecular systematic methods. Plant Systematics and Evolution (Supplement) 11: 237-259.

Scholin, C. A., D. M. ANDERSON, and M. L. Sogin. 1993. Two distinct small-subunit ribosomal RNA genes in the North American toxic dinoflagellate Alexandrium fundyense (Dinophyceae). Journal of Phycology 29: 209-216.

Scholin, C. A., M. Herzog, M. Sogin, and D. M. ANDERSON. 1994. Identification of group- and strain-specific genetic markers for globally distributed Alexandrium (Dinophyceae). II. Sequence analysis of a fragment of the LSU rRNA gene. Journal of Phycology 30: 999-1011.

SEBASTIÁN, C. R., and C. O'RYAN. 2001. Single-cell sequencing of dinoflagellate (Dinophyceae) nuclear ribosomal genes. Molecular Ecology Notes 1: 329-331.

SHERR, E. B., B. F. SHERR, and G.-A. PAFFENHÖFER. 1986. Phagotrophic protozoa a food for metazoans: A "missing" trophic link in marine pelagic food webs? Marine Microbial Food Webs 1: 61-80.

SMETACEK, V. 1981. The annual cycle of protozooplankton in the Kiel Bight. Marine Biology 63: 1-11.

STOECKER, D. K. 1999. Mixotrophy among Dinoflagellates. Journal of Eukaryotic Microbiology 46: 397-401. 
StoeCKeR, D. K., and J. MCDowell CaPuzzo. 1990. Predation on protozoa: Its importance to zooplankton. Journal of Plankton Research 12: 891-908.

SWOFFORD, D. L. 2002. PAUP*: Phylogenetic Analysis Using Parsimony (*and other methods), Version 4.0b10. Sinauer.

TAKANO, Y., and T. HORIGUCHI. 2005. Acquiring scanning electron microscopical, light microscopical and multiple gene sequence data from a single dinoflagellate cell. Journal of Phycology 42: 251-256.

TAYLOR, F. J. R. 1976. Dinoflagellates from the International Indian Ocean Expedition: A report on material collected by the R.V. "Anton Bruun" 1963-1964. E. Schweizerbart'sche Verlagsbuchhandlung.

---. 2004. Illumination or confusion? Dinoflagellate molecular phylogenetic data viewed from a primarily morphological standpoint. Phycological Research 52: 308-324.

TILlMANN, U., and K. J. HESSE. 1998. On the quantitative importance of heterotrophic microplankton in the northern German Wadden Sea. Estuaries 21: 585-596.

TISElius, P., and M. KUYLENSTIERNA. 1996. Growth and decline of a diatom spring bloom: Phytoplankton species composition, formation of marine snow and the role of heterotrophic dinoflagellates. Journal of Plankton Research 18: 133-155.

Venter, J. C., K. Remington, J. F. Heidelberg, A. L. Halpern, D. Rusch, J. Eisen, D. Wu, I. Paulsen, K. E. Nelson, W. Nelson, D. E. Fouts, S. LeVy, A. H. Knap, M. W. Lomas, K. Nealson, O. White, J. Peterson, J. Hoffman, R. Parsons, H. Baden-Tillson, C. PfannKoch, Y.-H. Rogers, and H. O. SMith. 2004. Environmental genome shotgun sequencing of the Sargasso Sea. Science 304: 66-74.

Verity, P. G., P. Wassman, M. E. Frisher, M. H. Howard-Jones, and A. E. Allen. 2002. Grazing of phytoplankton by microzooplankton in the Barents Sea during early summer. Journal of Marine Systems 38: 109-123.

vON STOCH, H. A. 1964. Zum problem der sexuellen fortpflanzung in der Peridineengattung Ceratium. Helgoländer wissenschaftliche Meeresuntersuchungen 10: 140-151.

---. 1972. La signification cytologique de la "cyclose nucléaire" dans le cycle de vie des Dinoflagellés. Soc. bot. Fr., Mémoires: 201-212. 
---. 1973. Observations on vegetative reproduction and sexual life cycles of two freshwater dinoflagellates, Gymnodinium pseudopalustre Schiller and Woloszynskia apiculata sp. nov. Br. Phycol. J. 8: 105-134.

WALL, D., and B. DALE. 1968. Modern dinoflagellate cysts and evolution of the Peridiniales. Micropaleontology 14: 265-304.

Whiteley, A. S., P. H. BurKILl, and M. A. Sleigh. 1993. Rapid method for cell cycle analysis in a predatory marine dinoflagellate. Cytometry 31: 100-109.

YAMAGUCHI, A., and T. HoRIGUCHI. 2005. Molecular phylogenetic study of the heterotrophic dinoflagellate genus Protoperidinium (Dinophyceae) inferred from small subunit rRNA gene sequences. Phycological Research 53: 30-42.

YAsumoto, T., T. IgARASHI, A. FUREY, K. J. JAMES, and K. KoIKE. 2002. Discovery of the origin of azaspiracids, Xth International Conference on Harmful Algae.

YeUNG, P. K. K., K. F. Kong, F. T. W. Wong, and J. T. Y. Wong. 1996. Sequence data for two large-subunit rRNA genes from an Asian strain of Alexandrium catenella. Applied and Environmental Microbiology 62: 4199-4201. 


\section{Appendix 1}

Protoperidinium species:

Group predators of large zooplankton or detritivores? 


\section{INTRODUCTION}

Protoperidinium are known to be species-specific consumers of large diatoms and dinoflagellates (Jacobson and Anderson 1986; Naustvoll 2000). As such, they may fill an ecological niche similar to that of zooplankton, as major consumers of marine eukaryotic primary production. There is evidence, however, that the nutritional strategy of Protoperidinium may be adaptable to differing environmental conditions and food availabilities. Protoperidinium species have been shown to be able to withstand long periods of starvation (Jakobsen and Hansen 1997; Menden-Deuer et al. 2005), and some species will consume conspecifics in culture if other food resources are limited (Jeong and Latz 1994; Jeong 1996; Naustvoll 2000).

Protozoa can be an important source of food for certain animals in particular environments. Microzooplankton like Protoperidinium are known to be prey for copepods and larval fish. Microzooplankton thus may form an important link in the marine food web between primary producers and larger consumers (Lessard and Swift 1985; Sherr et al. 1986; Stoecker and McDowell Capuzzo 1990).

In previous studies, Protoperidinium cf. divergens from the California coast was witnessed to consume both the eggs and live nauplii of the copepod Acartia tonsa in cultures. Predation rates of $P$. cf. divergens on $A$. tonsa eggs were high enough that $P$. cf. divergens could have a large impact on the population of the copepod in the field (Jeong 1996).

I observed many Protoperidinium divergens cells in a field sample from the southwest coast of Ireland collectively consume a single, large copepod. In culture, several other Protoperidinium species, including Protoperidinium steidingerae, Protoperidinium depressum, and Protoperidinium oblongum, have been observed to spread their feeding veils over flat, stationary surfaces to pick up or digest prey. The observations described 
here demonstrate that Protoperidinium do indeed exhibit feeding behaviors beyond strict species-specific one-on-one predation on phytoplankton, as is currently the paradigm.

\section{MATERIALS AND METHODS}

A field sample was collected by plankton net $(20 \mu \mathrm{m})$ from the Celtic Sea south of Ireland in late July 2003. The sample was contained in a tissue culture flask (Falcon, 353009, Becton Dickinson, Franklin Lakes, NJ) and rotated on a plankton wheel at 1-2 rpm. The sample was kept at $15^{\circ} \mathrm{C}$, under low light (ca. $50 \mu \mathrm{mol}$ photon $\mathrm{m}^{-2} \mathrm{sec}^{-1}$ ), with a light:dark cycle of 14:10 hr. Fresh seawater and Lingulodinium polyedrum prey were added to the culture approximately weekly. Observations of feeding were made August 5,2003 at $125 \mathrm{X}$ to $200 \mathrm{X}$ on a Zeiss IM35 inverted light microscope. Photographs were taken through the microscope ocular using a Nikon Coolpix digital camera.

Observations of cultured Protoperidinium cells extending pallia along the base of tissue culture flasks were made opportunistically. Photographs of these events were taken on a Zeiss Axiovert S100 with a Sony Exwave HAD 3CCD color video camera, using Scion Image 1.62 software.

\section{OBSERVATIONS}

\section{Feeding on copepod}

Multiple $P$. divergens cells were witnessed to feed simultaneously on a single, large copepod in a live field sample (Fig. 1 A-D). The copepod was $600 \mu \mathrm{m}$ long, exclusive of antennae. The $P$. divergens cells were approximately $96 \mu \mathrm{m}$ long by $80 \mu \mathrm{m}$ wide. As the initiation of feeding was not observed, it was unclear whether the copepod was alive or already dead when feeding began. During the period of observation, the copepod was clearly dead and stationary on the bottom of a tissue culture flask. While feeding occurred, $P$. divergens cells came and went randomly, each spending several minutes or more feeding on the copepod. 


\section{Figure 1.}

(A-D) Protoperidinium divergens cells consuming a copepod. (A) View of whole copepod, with more than 25 attached $P$. divergens cells. Scale bar $=100 \mu \mathrm{m}$. (B-D) Close up views of $P$. divergens cells with feeding veils extended at surface of copepod. Arrows indicate pallium material from $P$. divergens cells. Scale bar $=30 \mu \mathrm{m}$. (E-F) Protoperidinium steidingerae cell with pallium extended over bottom of tissue culture flask, around a Ditylum brightwellii diatom cell. Arrow indicates edge of pallium. Scale bar $=30 \mu \mathrm{m}$. 

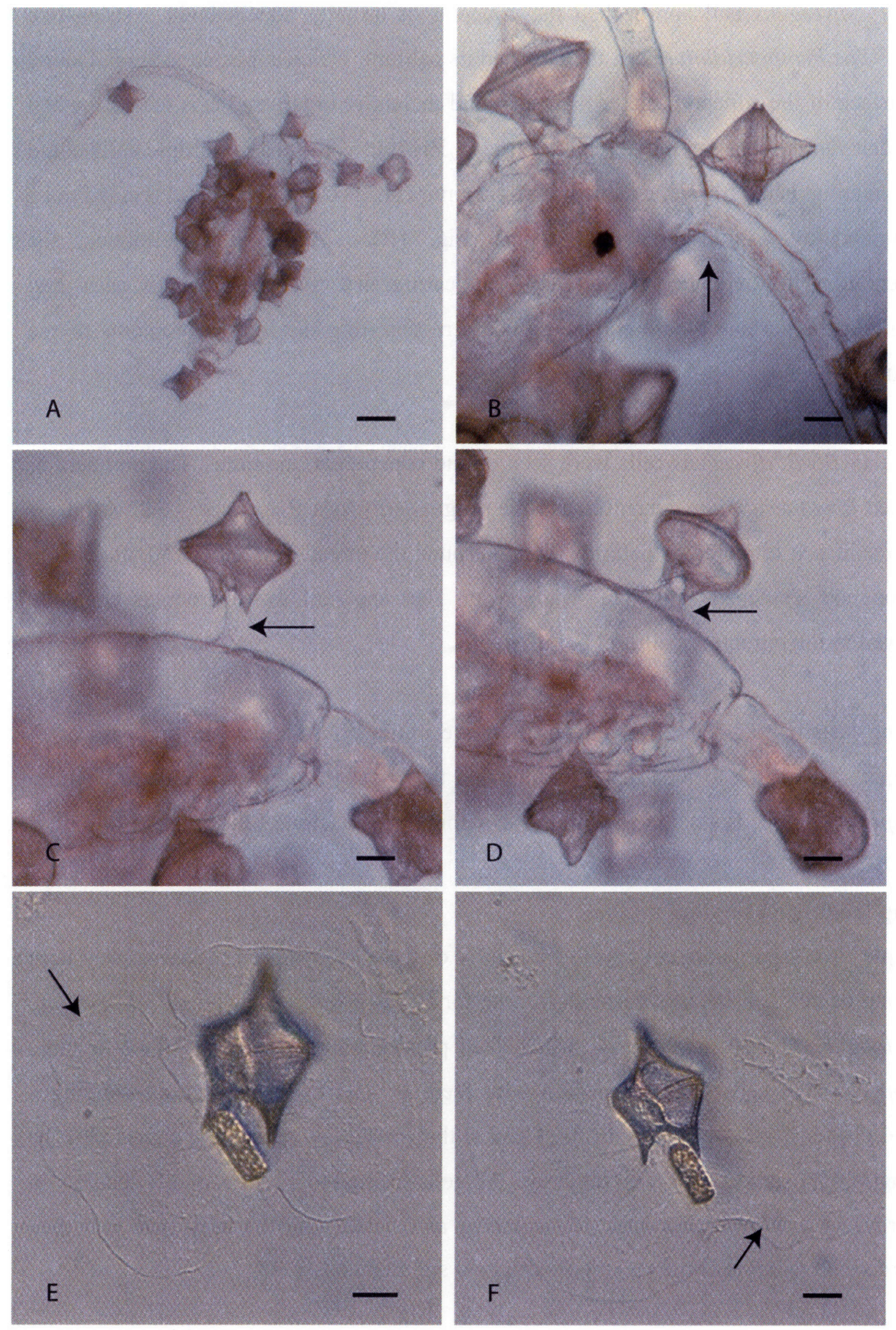
As a $P$. divergens cell approached the copepod, it initially attached via a string-like tether. The Protoperidinium cell then exuded its pallium, which appeared to spread along the surface of the copepod, rather than surround the entire organism, as is the case when Protoperidinium consume phytoplankton prey. Feeding veils from multiple cells could not be distinguished from one another, and the entire surface of the copepod seemed to be surrounded by a transparent pseudopod (Fig. 1B). As feeding continued, the pigmentation in the copepod decreased, indicating that the $P$. divergens cells had penetrated the surface of the copepod, and were digesting the internal contents of the organism.

More than $25 P$. divergens cells were seen on the copepod at one time. The numbers of attached Protoperidinium decreased as time progressed. As a $P$. divergens cell withdrew from feeding, it retracted its pallium, wound around the thread-like tether still attached to the copepod, detached, and then swam away. No apparent waste products could be observed in the retracting pallium.

Feeding lasted for $1.5 \mathrm{hr}$. from the time of the initial observation. In time, fewer $P$. divergens cells came to feed than were leaving the copepod, until finally there were no Protoperidinium cells associated with the remaining exoskeleton of the animal.

\section{Group feeding on phytoplankton}

Multiple Protoperidinium cells were frequently observed feeding on the same prey item or group of items. This was particularly true for Protoperidinium such as $P$. depressum, $P$. oblongum, and $P$. steidingerae, which feed preferentially on diatoms. Two or three Protoperidinium cells were often seen with feeding veils extended and surrounding a central cluster of diatom cells. In these cases, the Protoperidinium cells appeared to be pulling in opposite directions on the prey. All cells seemed to be successfully feeding on the prey, as the Protoperidinium all remained associated with the prey item and then discarded the remains of the prey approximately simultaneously. 


\section{Feeding from flat surfaces}

Protoperidinium appear able to feed on stationary objects on the bottom of a flask. Protoperidinium depressum, $P$. oblongum, and $P$. steidingerae cells were frequently witnessed to spread their pallia over diatoms settled on the bottom of the culture flask, with the pallium spreading widely over the surface of the flask (Fig. 1 E-F). The Protoperidinium cell then often retracted the pallium, scooping the prey item off the bottom of the flask in the process, and swam away with the prey.

\section{DISCUSSION AND CONCLUSIONS}

Group feeding by Protoperidinium has not been described previously. These observations point to the ability of these thecate heterotrophic dinoflagellates to pursue food resources other than phytoplankton prey.

Whether the copepod being consumed by Protoperidinium was alive or dead at the initiation of feeding, the observation overturns the paradigm of an orderly structure to the marine food web. If the copepod was alive and was killed by the Protoperidinium, then these thecate heterotrophic dinoflagellates may be able to prey in groups upon very large animals, perhaps acting as a "pack" to bring down and kill their prey. If, on the other hand, the copepod was dead at the initiation of feeding, then Protoperidinium may be able to act as detritivores on large organic particles. In that case these thecate heterotrophic dinoflagellates could be important not only in the consumption of primary productivity, but may also be important components in the in recycling of organic matter. One might also expect high Protoperidinium cell concentration at the sediment-water interface where detrital material accumulates.

Multiple cells feeding on the same diatom cluster in culture may have been an indication of food limitation, although there were many free diatom cells available for consumption when such observations were made, and there was no apparent decline in Protoperidinium growth rate in the culture, as might be caused by food limitation. 
Alternatively, several Protoperidinium cells feeding on the same prey item might be another example of group feeding similar to that of $P$. divergens feeding on a copepod.

Group feeding could provide a useful strategy for localized Protoperidinium populations in a patchy or food-poor environment, allowing more than one Protoperidinium cell to gain nutrition from a single prey item. The ability to consume a wide range of particle sizes and types, from phytoplankton of the same size up to animals seven times their size could greatly improve the chances for survival of these obligate heterotrophs in the field.

The observations of Protoperidinium picking prey off of a surface seem to point to an ability to feed on stationary or benthic items. This capacity could allow Protoperidinium species to feed on settled detritus or other organic particles. Such a capability makes it all the more puzzling why Protoperidinium cultures must be continuously rotated in order to survive. It has been postulated that rotation allows Protoperidinium easier access to their prey by keeping non-motile prey items in suspension, but this now appears not to be necessary.

If Protoperidinium routinely exploit food sources beyond phytoplankton prey and employ feeding mechanisms beyond a single predator consuming a single prey item, then extra care must be taken in interpreting the results of field studies. Extrapolating laboratorydefined grazing and growth rates from grazing on a single prey species to the field to determine the potential impact of Protoperidinium species on phytoplankton populations may not be valid if Protoperidinium are also able to consume a variety of nonphytoplankton prey. These observations could help to explain the perceived trophic mismatch between consecutive trophic levels in the marine environment.

\section{REFERENCES}

JACOBSON, D. M., and D. M. ANDERSON. 1986. Thecate heterotrophic dinoflagellates: Feeding behavior and mechanisms. Journal of Phycology 22: 249-258. 
JAKOBSEN, H. H., and P. J. HANSEN. 1997. Prey size selection, grazing and growth response of the small heterotrophic dinoflagellate Gymnodinium sp. and the ciliate Balanion comatum - a comparative study. Marine Ecology Progress Series 158: 75-86.

JEONG, H. J. 1996. The predation impact by the heterotrophic dinoflagellate Protoperidinium cf. divergens on copepod eggs in the presence of co-occurring phytoplankton prey. Journal of the Oceanological Society of Korea. Seoul 31: 144-149.

JEONG, H. J., and M. I. LATZ. 1994. Growth and grazing rates of the heterotrophic dinoflagellates Protoperidinium spp. on red tide dinoflagellates. Marine Ecology Progress Series 106: 173-185.

LESSARD, E. J., and E. SWIFT. 1985. Species-specific grazing rates of heterotrophic dinoflagellates in oceanic waters, measured with a dual-label radioisotope technique. Marine Biology 87: 289-296.

Menden-Deuer, S., E. J. Lessard, J. SATTERberg, and D. Grünbaum. 2005. Growth rates and starvation survival of three species of the pallium-feeding, thecate dinoflagellate genus Protoperidinium. Aquatic Microbial Ecology 41: 145-152.

NAUSTVOLL, L. J. 2000. Prey size spectra and food preferences in thecate heterotrophic dinoflagellates. Phycologia 39: 187-198.

SherR, E. B., B. F. SHERR, and G.-A. PAFFENHÖFER. 1986. Phagotrophic protozoa a food for metazoans: A "missing" trophic link in marine pelagic food webs? Marine Microbial Food Webs 1: 61-80.

StOECKER, D. K., and J. MCDowell CAPUZzo. 1990. Predation on protozoa: Its importance to zooplankton. Journal of Plankton Research 12: 891-908. 
Appendix 2

Observations of the asexual and sexual life history of Protoperidinium depressum (Dinophyceae) 


\section{INTRODUCTION}

Protoperidinium is one of the largest and most widespred genera of dinoflagellates. These heterotrophic species are found in marine waters from the tropics to the poles, and may play an important role in the trophic dynamics of plankton communities. Little is known of the life histories of Protoperidinium, however, limiting our understanding of the ecologies of these species.

In this study, I brought Protoperidinium depressum (Bailey) Balech into culture and documented the morphologies and dynamics of asexual and sexual life history stages in the species. While I am unable to fully define the life cycle of $P$. depressum based on this work, the observations made add to our understanding of the life histories of Protoperidinium species.

\section{MATERIALS AND METHODS}

\section{Cultures}

The clonal strain of Protoperidinium depressum used in this study (PDIR1A-Clone 1) was isolated off the western coast of Ireland in July of 2002. Protoperidinium depressum cultures were maintained in $0.2 \mu \mathrm{m}$-filtered, autoclaved seawater from Vineyard Sound (amended to $35 \mathrm{psu}$ by evaporation) with a mixture of Ditylum brightwellii (West) Grunow (CCMP 356), Chaetocerous affinis Lauder (CCMP 158), and Lingulodinium polyedrum (Stein) Dodge (GPES22) as prey. Cultures were contained in 70-mL tissue culture flasks (Falcon, 35009, Becton Dickinson, Franklin Lakes, NJ) without air space, and rotated on a plankton wheel at $1-2 \mathrm{rpm}$ at $15^{\circ} \mathrm{C}$ under low light $\left(50 \mu\right.$ mol photon $\mathrm{m}^{-2}$ $\mathrm{sec}^{-1}$ ) on a $14 \mathrm{~h}: 10 \mathrm{~h}$ light:dark cycle. Transfers were made every four to five days by pouring approximately two-thirds the volume of the old culture into a new flask containing fresh sterile filtered sea water and phytoplankton prey.

Cultures of diatom prey (CCMP 356, CCMP 158) were maintained in $25 \mathrm{~mL}$ of $\mathrm{f} / 2$ plus silicate nutrient medium (Guillard 1975) at $15^{\circ} \mathrm{C}$. Cultures of dinoflagellates (GPES 22) 
were maintained in $25 \mathrm{~mL}$ of ES nutrient medium (Kokinos and Anderson 1995) at 20

C. Both diatoms and dinoflagellates were kept at a photon flux density of ca. $100 \mu \mathrm{mol}$ $\mathrm{m}^{-2} \mathrm{~s}^{-1}$, on a $14 \mathrm{~h}: 10 \mathrm{~h}$ light:dark cycle.

\section{Species Identification}

Morphological species identification was confirmed by epifluorescence microscopy of cells stained with Calcofluor White MR2 (Polysciences, Warrington, PA \#4359), which stains cellulose thecal plates (Fritz and Triemer 1985) and by scanning electron microscopy (SEM).

\section{Calcofluor White}

Cultures and field samples were preserved with formalin ( $5 \%$ final concentration) and stored at $4^{\circ} \mathrm{C}$ until analysis. Samples were centrifuged, aspirated to a pellet, resuspended in $1 \mathrm{~mL}$ filtered seawater and mixed with $5 \mu \mathrm{L}$ of a $1.0 \mathrm{mg} \mathrm{mL}^{-1}$ solution of Calcofluor White. After staining for 10 minutes, the sample was aspirated to a pellet and then resuspended in 2 to $10 \mathrm{~mL}$ of filtered seawater for analysis. Subsamples of up to $1 \mathrm{~mL}$ were examined at $100-200 \mathrm{X}$ on a Zeiss Axioskop microscope with a $100 \mathrm{~W}$ mercury lamp and a Zeiss \#2 filter set (excitation $365 \mathrm{~nm}$, emission $420 \mathrm{~nm}$ ). Images were taken with a Zeiss MC 100 digital camera system.

\section{Scanning Electron Microscopy}

Cells were fixed for 30 minutes in $4 \%$ gluteraldhyde (final concentration) at $4{ }^{\circ} \mathrm{C}$. Samples were centrifuged ( $7 \mathrm{~min}$. at $4000 \mathrm{rpm}$ ), aspirated to a pellet, and resuspended in $10 \mathrm{~mL}$ filtered seawater. Individual cells were isolated by micropipette, washed $1 \mathrm{x}$ in filtered seawater, and deposited into filtered seawater.

Cells were collected onto Nucleopore filters $(25 \mathrm{~mm}, 8 \mu \mathrm{m}$ pore size), and rinsed in filtered seawater followed by $50 \%: 50 \%$ filtered seawater:DI water and then DI water. Samples were dehydrated with a series of increasing ethanol concentrations and critical 
point dried (Tousimis Samidri-780A). Filters were coated with gold palladium (Tousimis Samsputter-28) and examined on a scanning electron microscope (JEOL JSM-840).

\section{Nuclear and flagellar morphology of life cycle stages}

Eight replicate 70-mL tissue culture flasks (Falcon, 35009, Becton Dickinson, Franklin Lakes, NJ) were each inoculated with $5 \mathrm{~mL}$ of $P$. depressum clonal culture, $3 \mathrm{~mL}$ of $D$. brightwellii culture, $3 \mathrm{~mL}$ of $C$. affinis culture, and $1 \mathrm{~mL}$ of $L$. polyedrum culture, filled with filtered seawater, and cultured as described above. Fourteen days later, the contents of all flasks were combined and $10.5 \mathrm{~mL}$ of culture was redistributed into each of 10 new 35-mL tissue culture flasks (BD Biosciences 353107), along with $3 \mathrm{~mL}$ of $D$. brightwellii, $3 \mathrm{~mL}$ of $C$. affinis, and $1 \mathrm{~mL}$ of L. polyedrum. Flasks were maintained under the culture conditions described above.

Beginning immediately after inoculation, a single flask was harvested at each of nine time points at intervals of one to four hours over a 21 hour period. From each flask, 12 $\mathrm{mL}$ was preserved with gluteraldehyde ( $1 \%$ final concentration) and stored at $4^{\circ} \mathrm{C}$ for later staining with Dapi (data not presented), and $19 \mathrm{~mL}$ was preserved with modified Bouin's solution (5\% final concentration) (Coats and Heinbokel 1982) and stored at room temperature. Select Bouin's-preserved samples from the time series and six additional samples, taken randomly from the clonal culture of $P$. depressum, and preserved with modified Bouin's solution (5\% final concentration), were processed by Quantitative Protargol Staining (QPS) (Montagnes and Lynn 1993), and were examined using a Zeiss compound microscope. Specimens were measured and photographed at $400 \mathrm{X}$ to $1250 \mathrm{X}$ using a calibrated Zeiss AxioCam.

\section{Observations of live cells}

Single cells, dividing cells, or fusing gametes were isolated by micropipette into 48-well or 96-well Costar tissue culture plates with filtered seawater. Plates with isolated cells were held at $15^{\circ} \mathrm{C}$, except during observation. Observations of single cells were made on a Zeiss IM35 inverted microscope or a Zeiss Axiovert S100 inverted microscope. 
Digital photos were taken on a Zeiss Axiovert S100 microscope with a Sony Exwave HAD 3CCD color video camera, using Scion Image 1.62 software.

\section{Single-cell PCR amplification, cloning, and sequencing of partial LSU rDNA}

Single-cell PCR was used to amplify approximately $1430 \mathrm{bp}$ of domains D1-D6 of the large subunit ribosomal DNA (LSU rDNA). Single $P$. depressum cells of varying morphology were isolated from culture by micropipette. Each cell was washed 2-3 times in sterile filtered seawater and 1-2 times in sterile DI water before being deposited individually into a PCR tube in approximately $10 \mu \mathrm{L}$ of sterile DI water. PCR tubes with isolated cells were frozen at $-80^{\circ} \mathrm{C}$ overnight to enhance cell lysis. To further improve lysis, PCR tubes immersed in an ice bath were subjected to sonification (Branson Sonifier) bath at $40 \mathrm{~A}$ for approximately $1 \mathrm{~min}$.

The single lysed cells were used directly as template to amplify approximately $1430 \mathrm{bp}$ of the LSU rDNA using the primers D1R (Scholin et al. 1994) and 28-1483R (Daugbjerg et al. 2000). The PCR reaction mixture contained 2.5 units $P f u$ (Stratagene, La Jolla, CA), a proofreading DNA polymerase, $1 \mathrm{X}$ buffer, $0.3 \mu \mathrm{M}$ of each primer, and $0.2 \mathrm{mM}$ mixed dNTPs (Takara, Shiga, Japan). Thermal cycling was as follows: an initial denaturation at $95^{\circ} \mathrm{C}$ for $5 \mathrm{~min}$., 30 cycles of $95^{\circ} \mathrm{C}$ for $1 \mathrm{~min}$., $50^{\circ} \mathrm{C}$ for one min., $72^{\circ} \mathrm{C}$ for $2 \mathrm{~min}$., followed by a final elongation step of $72^{\circ} \mathrm{C}$ for $10 \mathrm{~min}$.

Between 25-30 $\mu \mathrm{L}$ of PCR product was run on a 1\% agarose gel. Positive bands were excised and the product purified and concentrated using a MinElute Gel Extraction Kit (Quiagen, Valencia, CA). Six purified PCR products were cloned separately using the Zero Blunt TOPO PCR Cloning Kit for Sequencing (Invitrogen, Carlsbad, CA). Primers T3, T7 (Invitrogen cloning kit), and D3B (Nunn et al. 1996) were used for sequencing 96 total clones for the six PCR products. Sequencing was done on an Applied Biosystems 3730XL capillary sequencer. Sequences were edited using Sequencher 4.5 software and aligned with ClustalX. 


\section{RESULTS}

\section{Morphological characteristics of vegetative cell}

Examination of thecal plate morphology by SEM confirmed that the species under study was $P$. depressum. The epitheca was convex near the cingulum then steeply sloped and nearly concave approaching the apical horn. The cingulum had lists supported by spines. The large 1' plate was four-sided (Fig. 1A-B). There were three dorsal intercalary plates, with a four sided 2a plate (Fig. 1C). Two antapical plates covered the short antapical horns. Live cells of similar morphology had a single longitudinal flagellum and a single transverse flagellum. These cells had a dark pink pigmentation to the cytoplasm and were observed to feed on diatoms in culture (Fig. 1D).

Protargol-stained specimens that corresponded with the overall morphology of live large cells averaged $96 \pm 6 \mu \mathrm{m}$ wide (Table 1, Fig. 1E). Due to the strong curvature of the cells, most protargol-stained specimens were oriented such that the cell length could not be reliably measured. The nucleus averaged $32 \pm 3 \mu \mathrm{m}$ wide by $24 \pm 3 \mu \mathrm{m}$ long and contained 1, 2, or 3 nucleoli. As in live specimens, these cells had one longitudinal flagellum and one transverse flagellum. Basal bodies were difficult to see in protargol stained samples due to the orientation of most cells and to heavy staining in the sulcal region, possibly of the feeding apparatus. In the few cases where basal bodies could be observed, a single pair was visible, associated with the two flagella. Given the single longitudinal flagellum, nucleus size and number of nucleoli, these cells were postulated to be haploid vegetative cells.

\section{Asexual reproduction}

Live cells were seen to divide by binary fission of the eleutheroschisis type (Pfiester and Anderson 1987), in which division takes place inside the theca of the parent cell. The parent cell settled to the bottom of the flask, immotile. The cytoplasm contracted from the apical and antapical horns and the sides of the theca, forming a division cyst in the center of the theca. In relatively short time, a division furrow formed at the edge of the 


\begin{tabular}{|c|c|c|c|c|c|}
\hline & & Vegetative & Dividing & Planozygote & $\begin{array}{l}\text { Nuclear } \\
\text { Cyclosis }\end{array}$ \\
\hline \multirow{3}{*}{$\begin{array}{l}\text { Cell Width } \\
\qquad(\mu \mathrm{m})\end{array}$} & Mean & 95.8 & 79.8 & 95.1 & 108 \\
\hline & $\boldsymbol{S}$ & 6.0 & 6.0 & 4.8 & - \\
\hline & Range & $79.2-106.6$ & $73.1-94.5$ & $87.7-101.5$ & - \\
\hline \multirow{3}{*}{$\begin{array}{c}\text { Nucleus } \\
\text { Width ( } \mu \mathrm{m})\end{array}$} & Mean & 32.5 & 37.4 & 31.5 & 57.3 \\
\hline & $\boldsymbol{S}$ & 3.1 & 3.9 & 1.7 & - \\
\hline & Range & $26.0-37.7$ & $29.5-43.3$ & $23.1-34.5$ & - \\
\hline \multirow{3}{*}{$\begin{array}{c}\text { Nucleus } \\
\text { Length }(\mu \mathrm{m})\end{array}$} & Mean & 24.0 & 21.1 & 23.0 & 26.8 \\
\hline & $S$ & 3.1 & 5.8 & 2.3 & - \\
\hline & Range & $12.1-28.7$ & $15.8-33.5$ & $19.0-25.8$ & - \\
\hline \multirow{3}{*}{$\begin{array}{l}\text { Number } \\
\text { Nucleoli }\end{array}$} & Mean & 2.0 & 3.3 & 4.1 & 1 \\
\hline & $\boldsymbol{S}$ & 0.8 & 1.6 & 0.8 & - \\
\hline & Range & $1.0-3.0$ & $2.0-6.0$ & $3.0-5.0$ & - \\
\hline Number & Mean & 1 & 1 & 2 & 2 \\
\hline Longitudinal & $S$ & 0 & 0 & 0 & - \\
\hline Flagella & Range & 1 & $0-1$ & 2 & - \\
\hline Number & Mean & 1 & 1 & 1 & 1 \\
\hline Transverse & $S$ & 0 & 0 & 0 & - \\
\hline Flagella & Range & 1 & $0-1$ & 1 & - \\
\hline $\mathbf{n}$ & & 32 & 13 & 10 & 1 \\
\hline
\end{tabular}

Table 1. Cell size, nucleus size, number of nucleoli and number of flagella for different life history stages of $P$. depressum, determined from protargol-stained specimens. 
cytoplasm, and the cytoplasm divided obliquely, forming two oblong lobes (Fig. 2A). Within two hours of division cyst formation, two daughter cells emerged, breaking through the mother theca at the cingulum (Fig. 2A-C).

Daughter cells emerged joined in an apical to antapical configuration, with the apical horn of one cell attached in the mid-posterior sulcal region of the other cell (Fig. 2D). These daughter cells were approximately half the size of the parent cell, weakly thecate or athecate, and relatively amorphous, lacking the pronounced apical and antapical horns of the vegetative cells and without sulcal or cingular lists. Within several minutes the daughter cells increased in size and expanded their apical and antapical horns. Daughter cells remained joined for anywhere from several minutes to more than an hour before separating and fully developing the characteristic $P$. depressum vegetative cell morphology.

Vegetative cells undergoing division were seen in protargol-stained samples. A series of events in asexual division were inferred from these static specimens based on observations of live dividing cells. The nucleus lengthened and became oval shaped and the nucleoli replicated (Fig. 2E). Once the division cyst formed, flagella were no longer visible, and presumably had been lost or resorbed. As cytokinesis began, the nucleus appeared to bend at the dividing line of the cell, and became V-shaped. Karyogamy occurred simultaneously with cytokinesis and the nucleus split at the center, leaving a "ragged edge" where the two halves separated (Fig. 2F). Daughter cells had separate nuclei and were attached in an apical horn-to-sulcus orientation (Fig. 2E). These stages were designated as asexual reproduction, since cells had one longitudinal and one transverse flagellum leading up to division, and since the resulting daughter cells each had a single pair of basal bodies and the same number of number of nucleoli as in vegetative cells. 


\section{Sexual reproduction}

In live cultures, two successive, rapid divisions of a large cell resulting in two pairs of smaller than average daughter cells were frequently observed (Fig. 3A-C). Division of smaller than average cells was also seen (Fig. 3D). In both cases, division was by eleutheroschisis, as in vegetative cells. When a single cell divided into four cells, the cell divided once to form two daughter cells which were attached in the same apical horn-tosulcus configuration as daughter cells typical of asexual reproduction. Before these second-generation daughter cells increased in size, however, and sometimes before they had separated, they quickly divided again (Fig. 3A), forming four small third-generation daughter cells. In cases where the second-generation daughter cells divided before separating, the four small third-generation daughter cells were initially contained in a single membrane-like structure (Fig. 3B) before separating into two pairs of cells (Fig. 3C).

The rapid division of a single cell to four small cells may be a "depauperate division" indicative of gametogenesis. The resulting cells were of similar size and morphology to those that were witnessed to fuse in culture, suggesting that they may have been gametes. Fusion of cells that had arisen from a rapid division to four cells was not directly observed, however.

In live cultures, smaller cells, averaging $42 \mu \mathrm{m}$ long by $50 \mu \mathrm{m}$ wide, were observed. These cells had a relatively clear cytoplasm, rounded apical horns, and short antapical horns (Fig. 4A) and were never observed to feed. Fusion of pairs of these cells indicated that they were gametes. 


\section{Figure 1.}

Vegetative cell stage of $P$. depressum. (A) Scanning electron micrograph of ventral epitheca, showing four-sided 1' plate. Scale bar $=10 \mu \mathrm{m}$. (B) Scanning electron micrograph of epitheca, showing four-sided 1' plate and three intercalary plates, including four-sided 2a plate. Scale bar $=10 \mu \mathrm{m}$. (C) Scanning electron micrograph of dorsal hypotheca, showing large 3"' plate and two antapical plates. (D) Live $P$. depressum cell, feeding on diatom cell. Scale bar $=20 \mu \mathrm{m}$. (E) Protargol-stained vegetative cell, showing single longitudinal flagellum and compact nucleus. Scale bar $=$ $20 \mu \mathrm{m}$. 

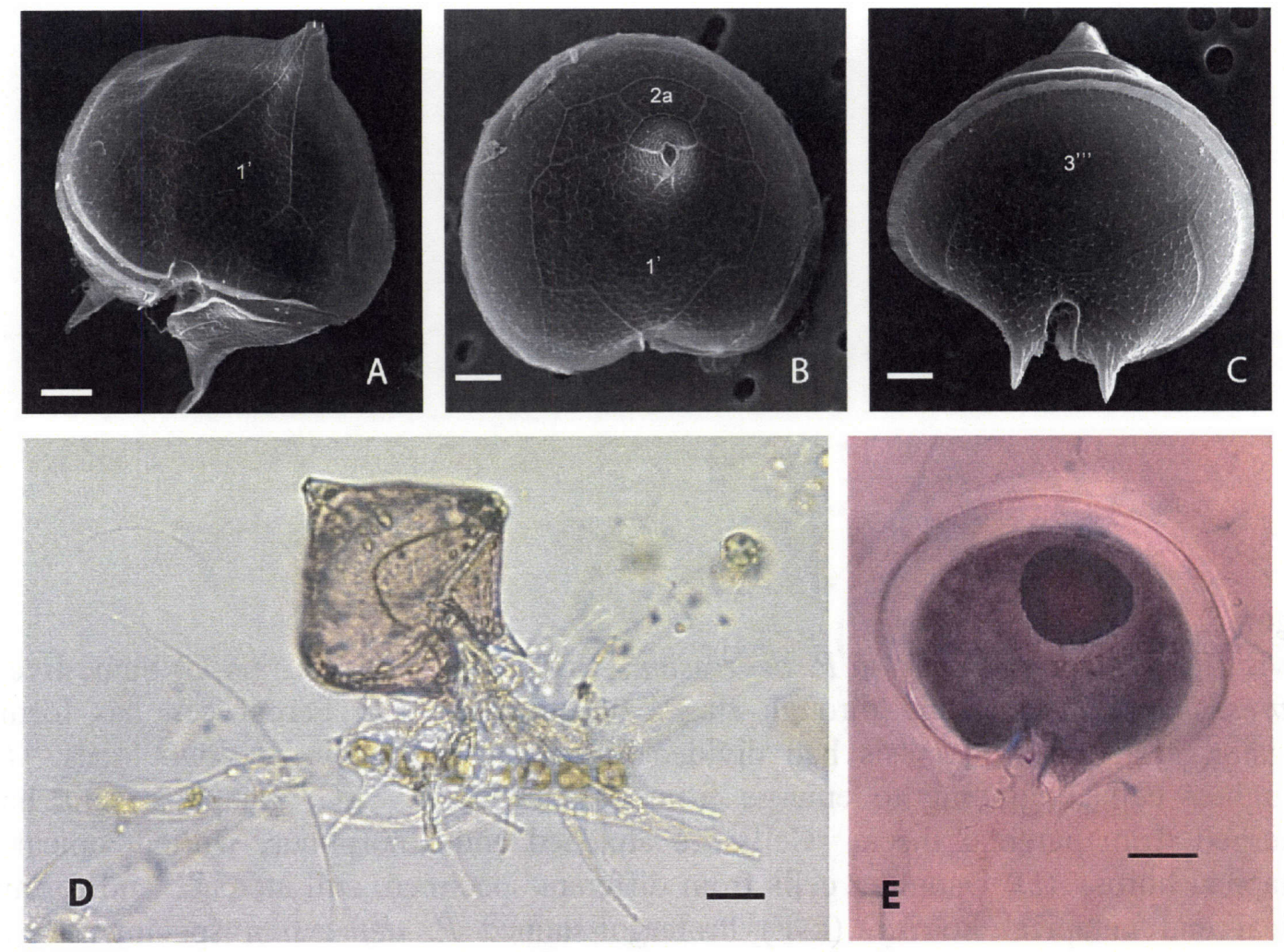
Figure 2.

Division by eleutheroschisis in $P$. depressum. Scale bars $=20 \mu \mathrm{m}$. (A-C) Same live $P$. depressum cell proceeding through stages of division. (A) Parent cell has formed division cyst and cytokinesis had divided cytoplasm obliquely into two lobes. (B) Daughter cells beginning to emerge from parental theca. (C) Daughter cells have emerged from parental theca. Cells are attached and amorphous, without apical or antapical horns. (D) Daughter cells from different specimen, still attached and forming apical and antapical horns. (E-F) Protargol-stained $P$. depressum specimens. (E) Nucleus elongate, karyokinesis beginning at center of nucleus. (F) Cytokinesis has occurred in division cyst. Karyokinesis was underway, as nucleus is pulling apart at the center. (G) Daughter cells with epitheca of posterior cell attached to sulcal region of anterior cell. 

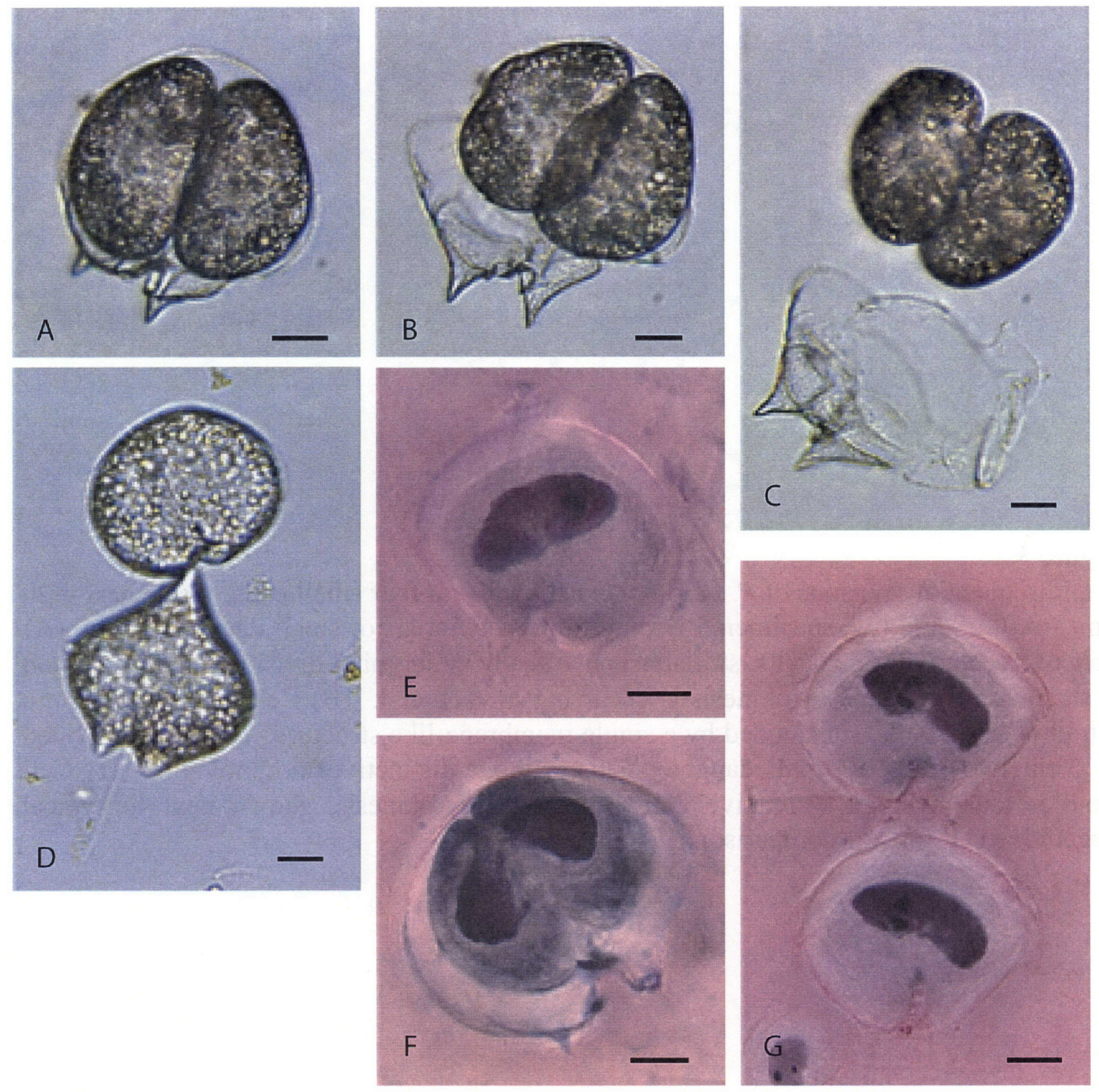
Figure 3.

Rapid sequential divisions of $P$. depressum cells to form four small cells. Scale bars $=20$ $\mu \mathrm{m}$. (A-C) Same live specimen, dividing to form two pair of small daughter cells. (A) Pair of recently divided cells, still attached, already undergoing division again. Division cysts have formed and cytokinesis is occurring in each cell. (B) Cell divided to form a tetrad of small cells, surrounded by a single membrane-like structure. (C) Tetrad divided to form two pairs of small daughter cells without distinctive morphology. (D) Cell smaller than average vegetative cell undergoing cytokinesis, shown next to typical vegetative cell for size comparison. 


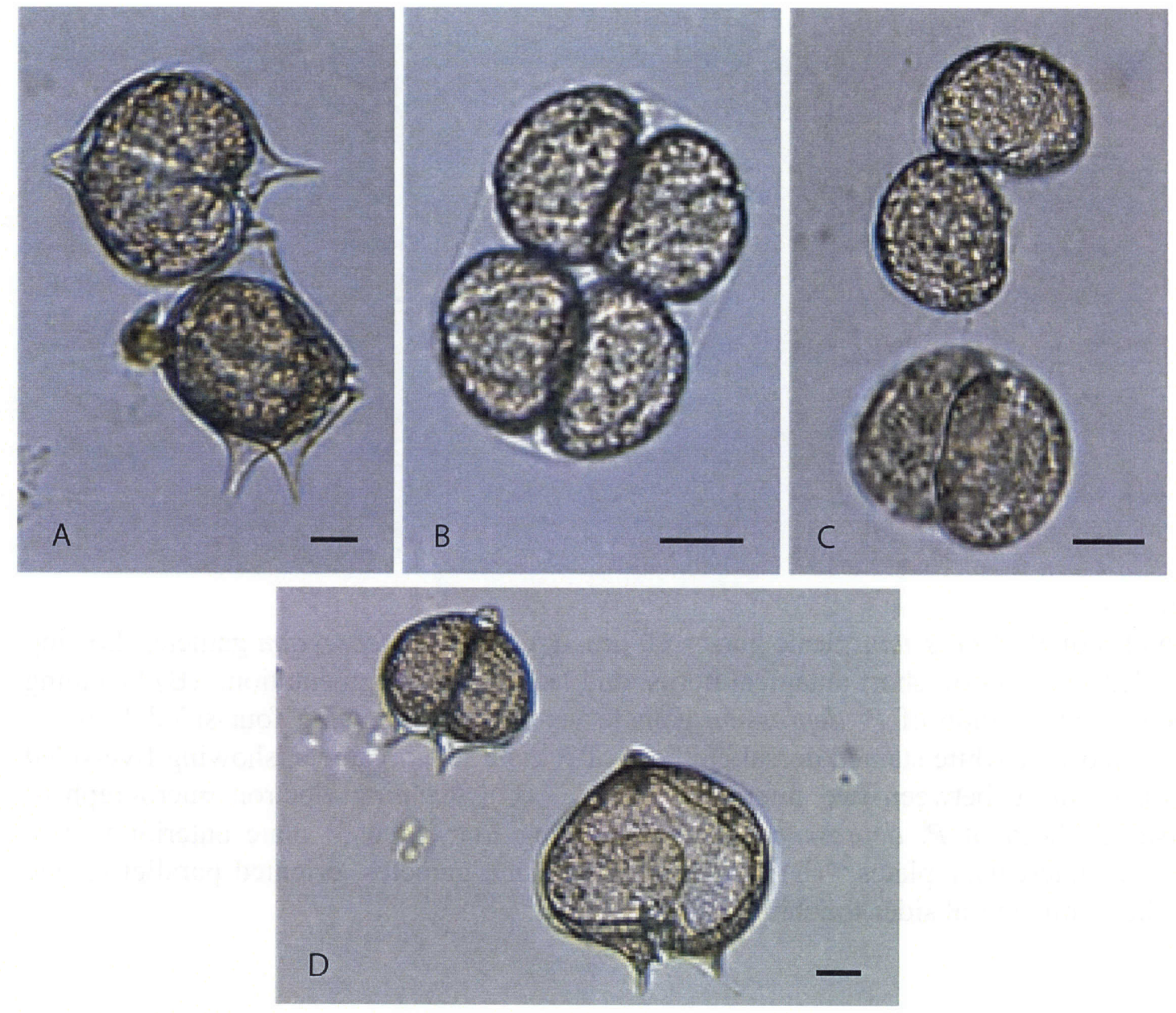


Figure 4.

Gametes of $P$. depressum. Scale bars $=10 \mu \mathrm{m}$. (A) Live $P$. depressum gamete, showing rounded apical horn, short antapical horns, and lack of pink pigmentation. (B) Scanning electron micrograph of $P$. depressum gamete ventral side, showing four-sided 1' plate. (C) Calcofluor white stained dorsal epitheca of $P$. depressum gamete, showing five-sided 3' plate sitting between two intercalary plates. (D) Scanning electron micrograph of dorsal epitheca of $P$. depressum gamete, showing four-sided 3' plate anterior to two adjacent intercalary plates. (E) Fusing $P$. depressum gametes, oriented parallel to one another with ventral sides touching. 

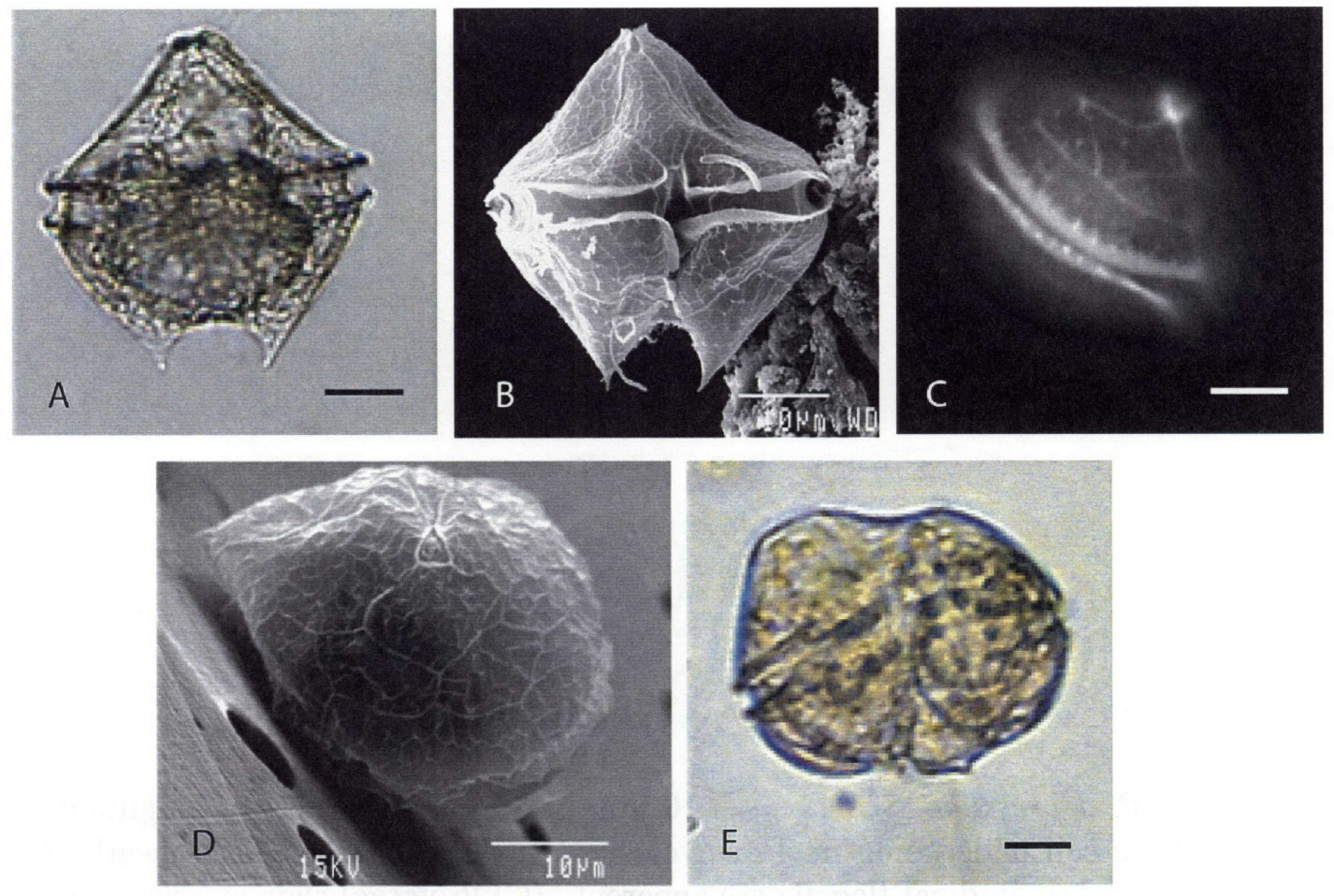
Figure 5.

Planozygotes of $P$. depressum. Scale bars $=10 \mu \mathrm{m}$. (A) Live cell with two longitudinal flagella. (B) Live cell undergoing nuclear cyclosis. Nucleus of cell extends nearly 80 $\mu \mathrm{m}$ across, and two longitudinal flagella are apparent. (C) Protargol stained planozygote undergoing nuclear cyclosis. The nucleus extends across entire cell. Chromosomes are stained and appear grainy. The nucleolus is large and centered in the nucleus. 

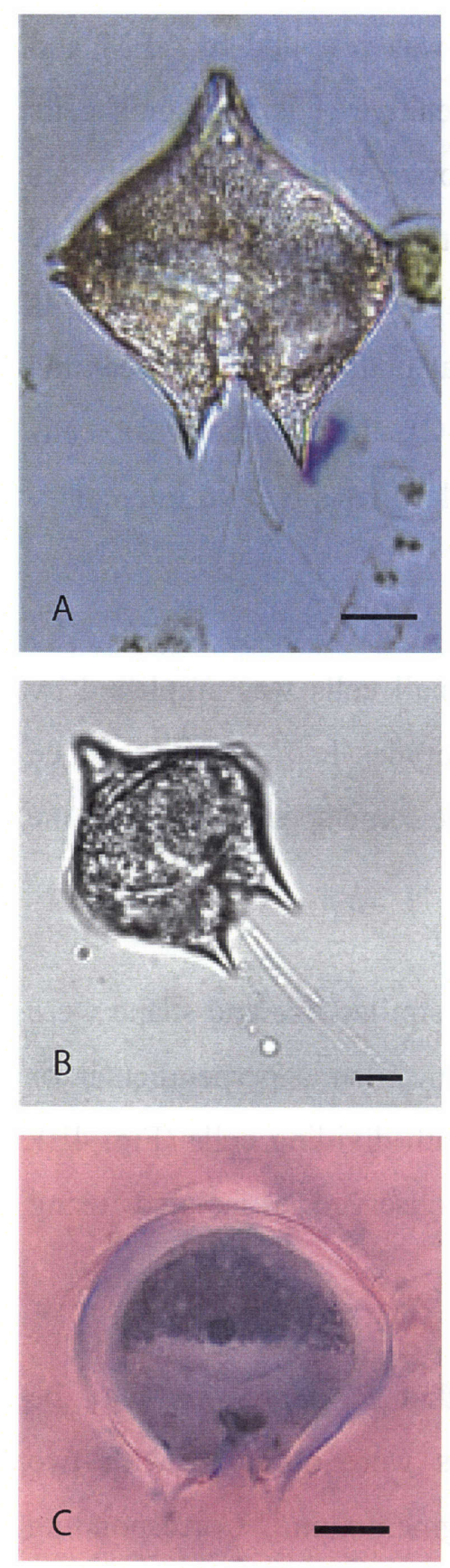
The thecal plate morphology of the presumptive gametes was revealed by SEM and staining with Calcofluor White (Fig. 4 B-D). Like the vegetative cells, the small cells had a four-sided first apical plate (Fig. 4B). Two different dorsal epithecal morphologies were apparent in cells of the same size range, however. Both types had two intercalary plates rather than the three typical of $P$. depressum vegetative cells. In one case, cells had a five-sided 3' plate that contacted the dorsal precingular plate and lay between the two intercalary plates, each of which was five-sided (Fig. 4C). In the other case, cells had a four-sided 3' plate separated from the dorsal precingular plates by two intercalary plates, each with five sides (Fig. 4D).

The D1-D6 region of the LSU rDNA of both large and small cells was amplified by single cell PCR, cloned and sequenced. The two morphotypes had $100 \%$ sequence identity, ensuring that the different cell types were indeed the same species, and that the small cells were not simply a culture contaminant.

Gametes fusion appeared to be isogamous. Pairs of cells of similar size and shape were seen to fuse together in live cultures. These pairs were in either a perpendicular or parallel, ventral-to-ventral orientation not easily confused with dividing cells (Fig. 4E). Unfortunately, the product of such fusions was not directly observed, as isolated fusing gametes perished before fusion was completed.

Gamete fusion occurred in a clonal culture, indicating that $P$. depressum may be homothallic. In the same clonal culture, live large cells were observed with two longitudinal flagella (Fig. 5A). These cells had pink pigmentation. Corresponding protargol-stained specimens with two longitudinal flagella and a single transverse flagellum averaged $95 \pm 5 \mu \mathrm{m}$ wide. Nuclei in these cells averaged $31 \pm 2 \mu \mathrm{m}$ wide by $23 \pm 2 \mu \mathrm{m}$ long and contained from 3 to 5 nucleoli. The presence of two longitudinal flagella and double the number of nucleoli than were in vegetative cells indicated that these specimens were likely diploid planozygotes, the result of sexual fusion of gametes. 
Nuclear cyclosis was observed in a single live planozygote that had been isolated into the well of a 96-well plate, (Fig. 5B). The nucleus was greatly enlarged, extending nearly across the entire width of the cell. The contents of the nucleus slowly swirled in a clockwise direction for more than five hours from the time of initial observation. During this time, the cell was motile, although it generally remained near the bottom of the well swimming in slow clockwise circles. The cell did not divide after cyclosis ceased, and died three days later without progressing to the next life cycle stage.

Protargol stained specimens were observed that appeared to correspond with the nuclear cyclosis stage (Fig. 5C). These cells, over $100 \mu \mathrm{m}$ wide, had two longitudinal flagella and a single transverse flagellum. The nucleus measured more than $55 \mu \mathrm{m}$ across and 25 $\mu \mathrm{m}$ long, and extended across the entire width of the cell, with grainy staining of the chromosomes instead of the uniformly dark staining of vegetative cell nuclei. A single large, round nucleolus was centered along the posterior edge of the nucleus. Despite the presence of sexual reproduction, no dormant cysts or hypnozygotes were ever observed in the cultures of $P$. depressum.

\section{DISCUSSION}

\section{Life history}

Many of the life history stages observed in $P$. depressum were similar to those observed in $P$. steidingerae Balech (Chapter 3, this thesis). In both species, asexual division is by eleutheroschisis. Daughter cells about half the size of the parent cell emerge from the parent theca without distinctive morphological features and are paired in the same apical horn-to-sulcus region orientation.

As in $P$. steidingerae, no stressors were necessary to induce sexuality in cultures of $P$. depressum. Sexual reproduction may be constitutive, although culture artifacts like high cell density or macro- or micro- nutrient limitation cannot be discounted as possible triggers for gamete production and sexuality. Both $P$. depressum and $P$. steidingerae 
produce small gametes with relatively clear pigmentation that were not observed to feed. In both species, fusing gamete pairs were isogamous, and in early stages of fusion were oriented perpendicularly with ventral sizes facing.

The meaning of the different thecal plate morphologies of the small cells is unknown. The two morphotypes may both be gametes, and gamete fusion may not be truly isogamous. Alternatively, one morphotype may be that of gametes, and the other is that of early stage planozygotes, the result of recent gamete fusion.

In both $P$. depressum and $P$. steidingerae, sexual reproduction appeared to be homothallic, occurring in presumptively clonal cultures. Given the similarity in the gross morphology of the vegetative cells and planozygotes within both species however, a diploid sexual stage could have been confused with a haploid vegetative cell and used to create a culture. In live cells, nuclear features were not visible and the number of longitudinal flagella was difficult to discern and was not checked at the time of isolation. Thus, there was a chance that a culture started from a single cell may have been composed of two compatible mating types. Cultures of $P$. depressum and $P$. steidingerae started from single cells had very low survival rates relative to cultures created from multiple cells. One might speculate that those cultures founded using a single diploid cell might have had a better chance for survival, and that the culture of $P$. depressum used in this study was not truly clonal.

In $P$. depressum, nuclear cyclosis (meiosis) occurred in the planozygote stage, and no dormant cysts were formed. This result contrasts with that for $P$. steidingerae, in which dormant cysts were observed in culture, and preliminary evidence indicated that nuclear cyclosis occured in the planomeiocyte that germinated from the cyst. 


\section{Implications of life history for species identification}

The gametes of $P$. depressum may have been previously mistaken for a separate species of Protoperidinium. All of the more than 200 species of Protoperidinium described to date (Balech 1974) have been identified from field specimens. Abé (1981) established the species $P$. consimilis, which is of the same size, shape, and thecal plate morphology as the gametes of $P$. depressum described here. Given that the life histories of all Protoperidinium species were undescribed until the research presented in this thesis, and that the various life cycle stages have quite different morphologies, it is not surprising that there has been mis-identification of life cycle stages as individual species.

Understanding the morphologies of different life history stages is important for understanding the results of ecological and laboratory studies, as well. In his Ph.D. thesis, Jeong described the formation of smaller than average Protoperidinium cells, and attributed these to food limitation in culture (Jeong 1995). No exploration of life history was included in the study, however. The results of the current study indicated that those smaller cells may have been incompletely developed daughter cells and/or sexual stages. Knowing which is the case would be relevant to the interpretation of growth and grazing rate studies.

The results of this study should be considered preliminary. Currently, many of the observations made have not been linked into a full cycle by rigorous experimentation or observational study. There may be alternative explanations beyond those given here for some of the observations made. Additional stages not identified by this study may exist in the life cycle of $P$. depressum.

\section{ACKNOWLEDGEMENTS}

Thank you to the Marine Institute of Ireland for assistance with sample collection. This study was funded by the Comer Foundation and the Carroll Wilson Award from the MIT Entrepreneurship Society. 


\section{REFERENCES}

Aвé, T. H. 1981. Studies on the Family Peridiniidae: An Unfinished Monograph of the Armoured Dinoflagellata. Academia Scientific Book, Inc.

BALECH, E. 1974. El genero Protoperidinium Bergh, 1881 (Peridinium Ehrenberg, 1831, Partim). Revista del Museo Argentino de Ciencias Naturales "Bernardino Rivadavia" e Instituto Nacional de Investigacion de las Ciencias Naturales 4: 179.

COATS, D. W., and J. F. HEINBOKEL. 1982. A study of reproduction and other life cycle phenomena in planktonic protists using an acridine orange fluorescence technique. Marine Biology 67: 71-79.

DaugbJerg, N., G. HANSen, J. Larsen, and Ø. MoestruP. 2000. Phylogeny of some of the major genera of dinoflagellates based on ultrastructure and partial LSU rDNA sequence data, including the erection of three new genera of unarmoured dinoflagellates. Phycologia 39: 302-317.

FrITZ, L., and R. E. TRIEMER. 1985. A rapid simple technique utilizing Calcofluor white M2R for the visualization of dinoflagellate thecal plates. Journal of Phycology 21: 662-664.

GUILlARD, R. R. L. 1975. Culture of phytoplankton for feeding marine invertebrates. In W. L. Smith and M. H. Chanley [eds.], Culture of Marine Invertebrates. Plenum Publishing Corporation.

JEONG, H. J. 1995. The interactions between microzooplanktonic grazers and dinoflagellates causing red tides in the open coastal waters off southern California, p. 139, Oceanography. University of California San Diego.

KoKINOS, J. P., and D. M. ANDERSON. 1995. Morphological development of resting cysts in cultures of the marine dinoflagellate Lingulodinium polyedrum $(=L$. machaerophorum). Palynology 19: 143-166.

Montagnes, D. J. S., and D. H. LYNN. 1993. A Quantitative Protargol Stain (QPS) for ciliates and other protists, p. 229-240. In P. F. Kemp, B. F. Sherr, E. B. Sherr and J. B. Cole [eds.], Handbook of Methods in Aquatic Microbial Ecology. Lewis Publishers, CRC Press, Inc. 
Nunn, G. B., B. F. Theisen, B. Christensen, and P. ArCtander. 1996. Simplicitycorrelated size growth of the nuclear 28S ribosomal RNA D3 expansion segment in the crustacean order Isopoda. Journal of Molecular Evolution 42: 211-223.

Pfiester, L. A., and D. M. Anderson. 1987. Dinoflagellate reproduction, p. 611-648. In F. J. R. Taylor [ed.], The Biology of Dinoflagellates. Botanical Monographs. Blackwell Scientific Publications.

Scholin, C. A., M. Herzog, M. Sogin, and D. M. Anderson. 1994. Identification of group- and strain-specific genetic markers for globally distributed Alexandrium (Dinophyceae). II. Sequence analysis of a fragment of the LSU rRNA gene. Journal of Phycology 30: 999-1011. 
